
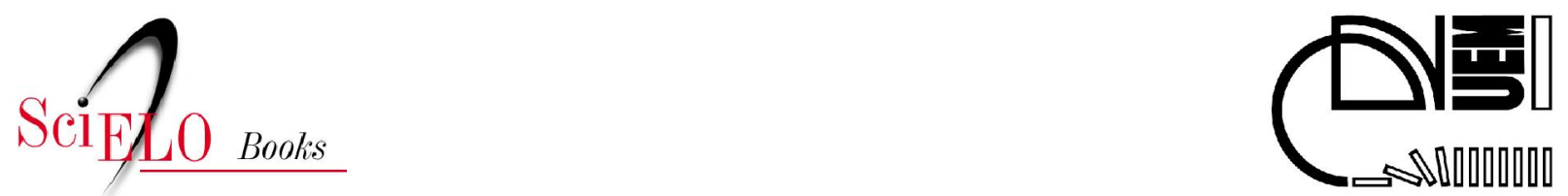

\title{
Peixes do baixo rio Iguaçu
}

\author{
Gilmar Baumgartner \\ Carla Simone Pavanelli \\ Dirceu Baumgartner \\ Alessandro Gasparetto Bifi \\ Tiago Debona \\ Vitor André Frana
}

\section{(1) (1) $\Theta(9)$}

All the contents of this chapter, except where otherwise noted, is licensed under a Creative Commons Attribution-Non Commercial-ShareAlike 3.0 Unported.

Todo o conteúdo deste capítulo, exceto quando houver ressalva, é publicado sob a licença Creative Commons Atribuição Uso Não Comercial - Partilha nos Mesmos Termos 3.0 Não adaptada.

Todo el contenido de este capítulo, excepto donde se indique lo contrario, está bajo licencia de la licencia Creative Commons Reconocimento-NoComercial-CompartirIgual 3.0 Unported. 


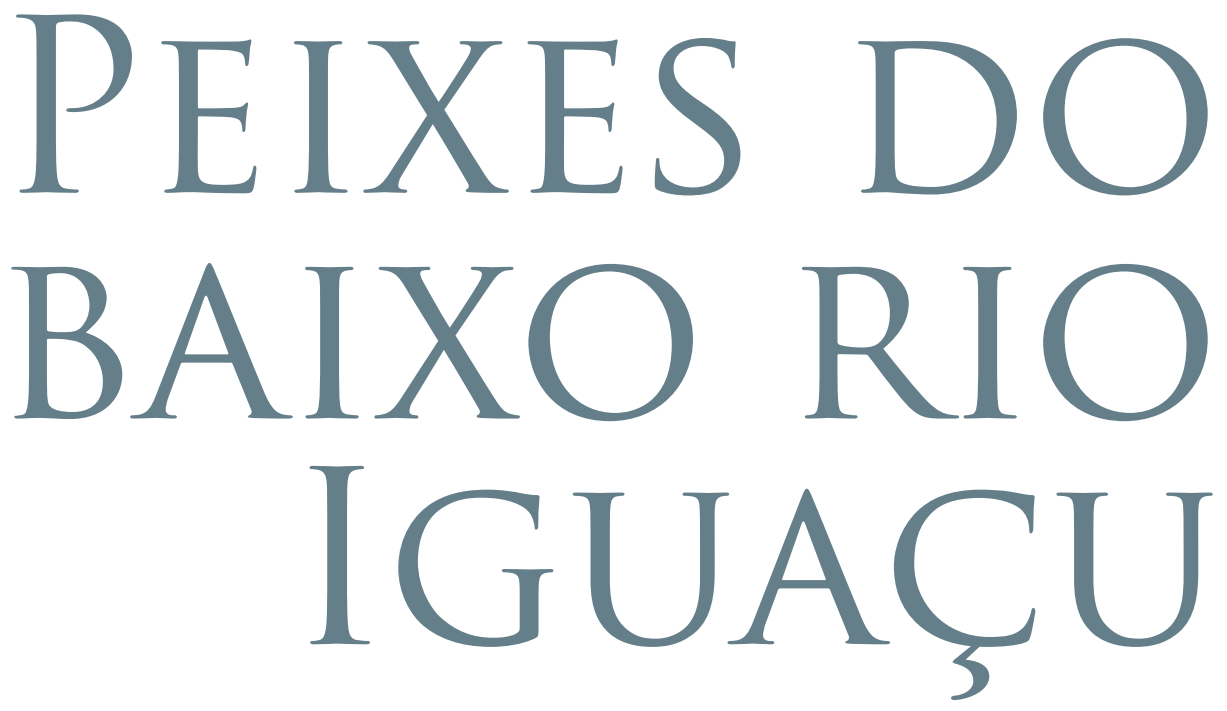

Gilmar Baumgartner Carla Simone Pavanelli Dirceu Baumgartner Alessandro Gasparetto Bifi Tiago Debona Vitor André Frana 


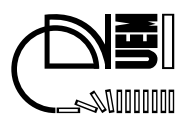

EDITORA DA UNIVERSIDADE ESTADUAL DE MARINGÁ

\begin{tabular}{|c|c|}
\hline Reitor & Prof. Dr. Júlio Santiago Prates Filho \\
\hline Vice-Reitor & Profa. Dra. Neusa Altoé \\
\hline Diretor da Eduem & Prof. Dr. Alessandro de Lucca e Braccini \\
\hline \multirow[t]{2}{*}{ Editora-Chefe da Eduem } & Profa. Dra. Terezinha Oliveira \\
\hline & CONSELHO EDITORIAL \\
\hline Presidente & Prof. Dr. Ivanor Nunes do Prado \\
\hline \multirow[t]{26}{*}{ Editores Científicos } & Prof. Adson Cristiano Bozzi Ramatis Lima \\
\hline & Profa. Dra. Ana Lúcia Rodrigues \\
\hline & Profa. Dra. Analete Regina Schelbauer \\
\hline & Prof. Dr. Antonio Ozai da Silva \\
\hline & Prof. Dr. Clóves Cabreira Jobim \\
\hline & Profa. Dra. Eliane Aparecida Sanches Tonolli \\
\hline & Prof. Dr. Eduardo Augusto Tomanik \\
\hline & Prof. Dr. Eliezer Rodrigues de Souto \\
\hline & Prof. Dr. Evaristo Atêncio Paredes \\
\hline & Profa. Dra. Ismara Eliane Vidal de Souza Tasso \\
\hline & Prof. Dr. João Fábio Bertonha \\
\hline & Profa. Dra. Larissa Michelle Lara \\
\hline & Profa. Dra. Luzia Marta Bellini \\
\hline & Profa. Dra. Maria Cristina Gomes Machado \\
\hline & Profa. Dra. Maria Suely Pagliarini \\
\hline & Profa. Dra. Maria Terezinha Bellanda Galuch \\
\hline & Prof. Dr. Manoel Messias Alves da Silva \\
\hline & Prof. Dr. Oswaldo Curty da Motta Lima \\
\hline & Prof. Dr. Raymundo de Lima \\
\hline & Prof. Dr. Reginaldo Benedito Dias \\
\hline & Prof. Dr. Ronald José Barth Pinto \\
\hline & Profa. Dra. Rosilda das Neves Alves \\
\hline & Profa. Dra. Terezinha Oliveira \\
\hline & Prof. Dr. Valdeni Soliani Franco \\
\hline & Profa. Dra. Valéria Soares de Assis \\
\hline & EQUIPE TÉCNICA \\
\hline \multirow{5}{*}{$\begin{array}{r}\text { Projeto Gráfico e Design } \\
\text { Fluxo Editorial }\end{array}$} & Marcos Kazuyoshi Sassaka \\
\hline & Edilson Damasio \\
\hline & Edneire Franciscon Jacob \\
\hline & Mônica Tanamati Hundzinski \\
\hline & Vania Cristina Scomparin \\
\hline \multirow[t]{2}{*}{ Artes Gráficas } & Luciano Wilian da Silva \\
\hline & Marcos Roberto Andreussi \\
\hline Marketing & Marcos Cipriano da Silva \\
\hline \multirow[t]{3}{*}{ Comercialização } & Norberto Pereira da Silva \\
\hline & Paulo Bento da Silva \\
\hline & Solange Marly Oshima \\
\hline
\end{tabular}


PEIXES DO BAIXO RIO IGUAÇU

Prefácio
Agostinho

$\underset{\substack{\text { Maringa } \\ \text { 2012 }}}{\text { (1) }}$ 
Copyright $(2) 2012$ para os autores

Gilmar Baumgartner, Carla Simone Pavanelli, Dirceu Baumgartner, Alessandro Gasparetto Bifi, Tiago Debona, Vitor André Frana

Todos os direitos reservados. Proibida a reprodução, mesmo parcial, por qualquer processo mecânico, eletrônico, reprográfico etc., sem a autorização, por escrito, dos autores. Todos os direitos reservados desta edição 2012 para a Eduem.

\section{Revisor: Carlos Alexandre Venancio}

Referências e Ficha Catalográfica:

Maria Salete Ribelatto Arita CRB 9/858

João Fábio Hildebrandt CRB 9/1140

Painel da Capa: Rogério Dias

Ilustrações de Peixes: Gabriel de Carvalho Deprá

Fotos dos Peixes: Celso Ikedo, Tiago Debona, Vitor André Frana e Alessandro Gasparetto Bifi

Tiragem: 2.000 exemplares

\section{Produção Editorial:}

Sinergia - Mídia e Convergência

www.sinergiamc.com.br

\section{7}

\section{A. Venancio}

Eliane Arruda

Maykon Patrick de Oliveira Martins

Leonardo Marques

Impressão:

Gráfica Regente

"Dados Internacionais de Catalogação-na-Publicação (CIP)" (Biblioteca Setorial - UEM. Nupélia, Maringá, PR, Brasil)

P379 Peixes do baixo rio Iguaçu / Gilmar Baumgartner ... [et al.]. ; ilustrações de peixes Gabriel de Carvalho Deprá ; prefácio Ângelo Antônio Agostinho. -- Maringá : Eduem, 2012.

xix, 203 p. : il. color.

Outros autores: Carla Simone Pavanelli, Dirceu Baumgartner Alessandro Gasparetto Bifi, Tiago Debona, Vitor André Frana. Bibliografia: p. 188 - 196.

Inclui glossário.

ISBN 978-85-7628-426-0 (Capa dura).

1. Peixes de água doce - Taxonomia - Iguaçu, Rio, Bacia - Paraná (Estado). 2. Peixes de água doce - Endemismo - Iguaçu, Rio, Bacia - Paraná (Estado). 3. Ictiofauna - Identificação - Iguaçu, Rio, Bacia Paraná (Estado). I. Baumgartner, Gilmar, 1963- . . II. Pavanelli, Carla Simone, 1967- . . III. Baumgartner, Dirceu, 1973- . .IV. Bifi, Alessandro Gasparetto, 1981- . V. Debona, Tiago, 1978- . VI. Frana, Vitor André, 1980- . VII. Deprá, Gabriel de Carvalho, 1988- ,il.

CDD 22. ed. -597.1764098162 NBR/CIP - 12899 AACR

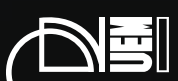

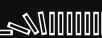

Eduem - Editora da Universidade Estadual de Maringá Av. Colombo, 5790 - Bloco 40 - Campus Universitário 87020-900 - Maringá - Paraná

Fone: (0xx44) 3011-4103 / Fax: (0xx44) 3011-1392 http://www.eduem.uem.br / eduem@uem.br 


\section{A G R A DECIMENTOS}

A consecução desta obra não seria possível sem a contribuição de várias pessoas e instituições, deste modo, gostaríamos de expressar nossos sinceros agradecimentos:

À companhia Paranaense de Energia (Copel) e à Tractebel Energia S.A., pelo financiamento dos projetos "Estudos ictiológicos no reservatório de Segredo", "Estudos ictiológicos no reservatório de Salto Caxias", "Estudos ictiológicos e monitoramento da qualidade da água dos reservatórios de Salto Santiago e Salto Osório, rio Iguaçu/PR" e "Análise biológica de peixes", que permitiram registrar a grande maioria das espécies de peixes mencionadas neste catálogo.

Ao Núcleo de Pesquisas em Limnologia, Ictiologia e Aquicultura (Nupélia), da Universidade Estadual de Maringá, ao Grupo de Pesquisas em Recursos Pesqueiros e Limnologia (Gerpel), da Universidade Estadual do Oeste do Paraná, e à Fundação Universitária de Toledo, pelo apoio logístico no desenvolvimento dos projetos mencionados acima e durante a elaboração desta obra.

Ao Celso Ikedo, do Nupélia, pela confecção de parte das fotos.

À Maria Salete Ribelatto Arita, pela revisão das referências bibliográficas.

Aos servidores do Nupélia, Samuel Veríssimo, João Dirço Latini, Wladimir Marques Domingues, Harumi Irene Suzuki, Rosemara Fugi, Ângela Maria Ambrósio, Marli de Campos, Alfredo Soares da Silva, Francisco Alves Teixeira, Sebastião Rodrigues e Valdir Aparecido Capatti, pelo auxílio nas coletas de dados.

Aos senhores Luis Augusto Marques Ludwig, Geraldo Stumm, Claiton Bastian, César Dalbosco, Edimar Gonçalves, Abraão Ferreira Moraes, Estefano Myszak, Antonio Sella Zolet, Adão Mendes dos Santos, Edilson Tarcheviski, José Aparecido de Souza Melo, Sebastião Henk, Vanderlei da Silva e Éder Felipe Morschbacher, funcionários da Copel, pelo auxílio na coleta de material.

Aos senhores Clóvis Agripino Tosin da Silva, Anderson Gibathe, Geocir Sandrin e Mauri Osmar Batista, funcionários da Tractebel Energia, pelo auxílio nas coletas de dados.

À equipe do Gerpel, Pedro Rogério Leandro da Silva, Vinicius Valiente dos Santos, Anderson Luis Maciel, Tatiane Mary Gogola, Vanessa Salete Daga, Carlos Henrique Orsi, Luciano Caetano de Oliveira, Márcio Roberto Michelon, Cleomar Fernandes, Pitágoras Augusto Piana, Éder André Gubiani, Maria do Carmo Gominho Rosa, Paulo Vanderlei Sanches, Cleodimar Fernandes, Nyamien Yahaut Sebastien e Adriana Tonco Johann, pelo auxílio na obtenção de dados.

Ao Eléxio Vidal e Edna Aparecida de Oliveira, pelo fornecimento de exemplares de Piaractus mesopotamicus, para confecção de fotos.

Ao prof. Aldi Feiden e Ronan Rorato (in memorian), pela disponibilização de exemplares de Steindachneridion melanodermatum, para confecção de fotografia.

Ao Weferson Júnio da Graça, Cláudio Henrique Zawadzki, Henrique Varella, Carlos Miranda de Oliveira, Luiz Roberto Malabarba e Flávio Alicino Bockmann, pelo auxílio na identificação do material analisado.

À Mariana Sarragiotto e Héctor Samuel Vera Alcaraz, pelo auxílio na tomada de alguns dados morfomerísticos.

Ao Luiz Roberto Malabarba pelo fornecimento de medidas e fotos do exemplar do "Gênero indeterminado".

Ao Wolmar Wosiacki, pelo fornecimento da foto de Trichomycterus mboycy.

Ao Vinícius Abilhoa, pelo fornecimento da foto do Salto Caiacanga e empréstimo de material.

Ao Leonardo Ferreira da Silva Ingenito, Marcos Aurélio Zanella e Apolônio Rodrigues, pelo fornecimento de fotos de lugares ao longo do rio Iguaçu.

À Dione Seripierri pelo fornecimento de material bibliográfico.

Ao Ângelo Antônio Agostinho, pela gentil elaboração do prefácio. 



\section{OS RIOS}

Os rios que eu encontro vão seguindo comigo.

Rios são de água pouca, em que a água sempre está por um fio.

Cortados no verão que faz secar todos os rios.

Rios todos com nome e que abraço como a amigos.

Uns com nome de gente, outros com nome de bicho, uns com nome de santo, muitos só com apelido. Mas todos como a gente que por aqui tenho visto:

a gente cuja vida se interrompe quando os rios.

João Cabral de Melo Neto 


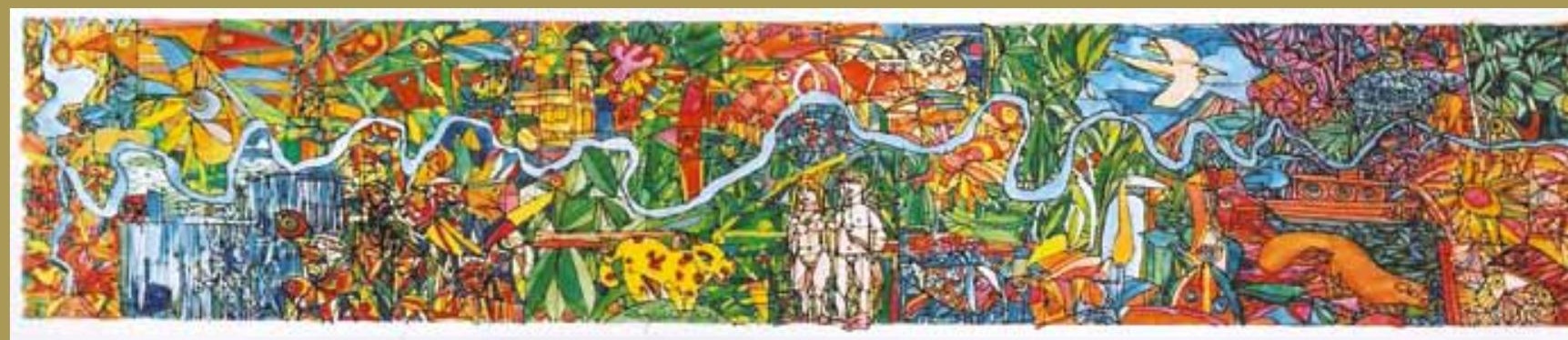

Painel:
O rio Iguaçu,
do artista Rogério Dias. 


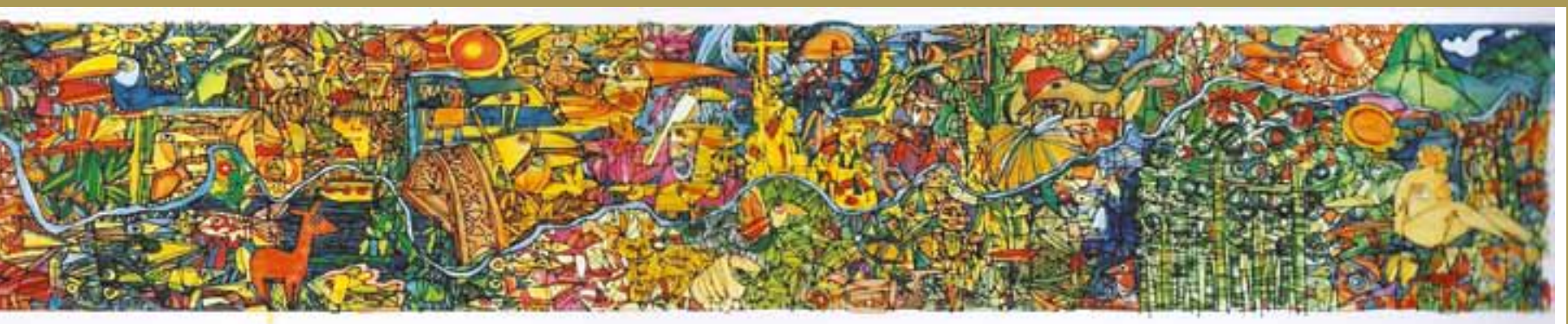

\section{Lenda das Cataratas}

Uma linda lenda tupi-guarani explica o surgimento das Cataratas do Iguaçu. "Há muitos anos atrás, o rio Iguaçu corria livre, sem corredeiras e nem cataratas. Em suas margens habitavam índios caingangues, que acreditavam que o mundo era governado por M'Boy, o Deus Serpente, filho de Tupã.

O cacique da tribo, Igobi, tinha uma bela filha chamada Naipí. Devido à sua beleza, Naipí seria consagrada ao Deus M'Boy, passando a viver somente para seu culto. Havia, porém, entre os caingangues, um jovem guerreiro chamado Tarobá, que, ao ver Naipí, por ela se apaixonara.

No dia em que foi anunciada a festa de consagração da bela índia, quando o cacique e o pajé bebiam "cauim" (bebida feita de milho fermentado) e os guerreiros dançavam, Tarobá fugiu com Naipí em uma canoa, que seguiu rio abaixo, arrastada pela correnteza.

Quando M'Boy soube da fuga, ficou furioso. Penetrou então nas entranhas da terra e retorcendo o seu corpo, produziu uma enorme fenda, que formou uma catarata gigantesca. Envolvidos pelas águas dessa imensa cachoeira, os fugitivos caíram de grande altura.

Naipí transformou-se em uma rocha abaixo da cachoeira, perpetuamente fustigada pelas águas revoltas e Tarobá foi convertido em uma palmeira, situada à beira do abismo, condenado a contemplar eternamente sua amada sem poder tocá-la. Debaixo dessa palmeira acha-se a entrada de uma gruta onde o monstro vingativo vigia, eternamente, as suas duas vítimas".

Adaptado de: CARNEIRO JR. Renato A. (coord.). Lendas e contos populares do Paraná. Curitiba: Secretaria de Estado da Cultura do Paraná, 2005 (Caderno Paraná da Gente; 3). 


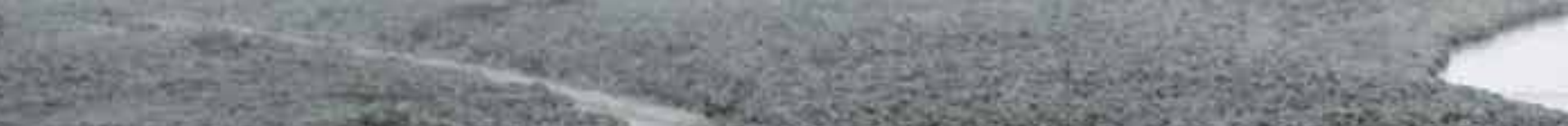

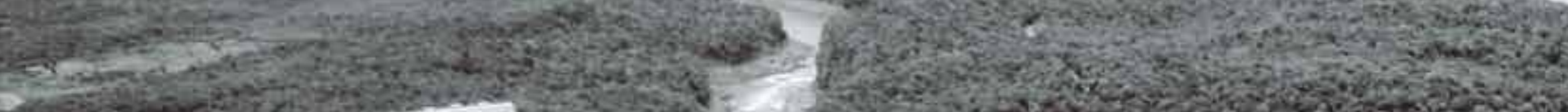

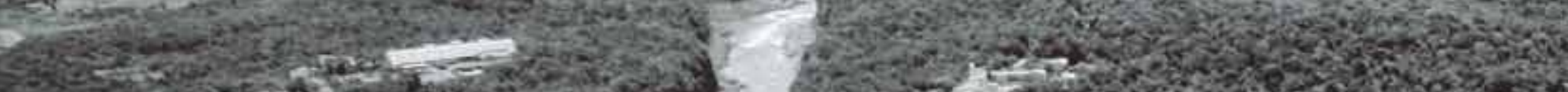

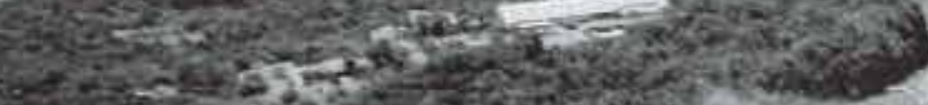

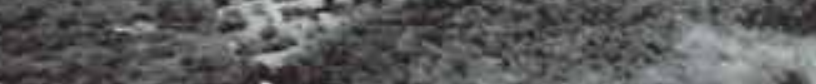
2.t. 1. E.

$50,2 x$ $\rightarrow x^{2}+8$

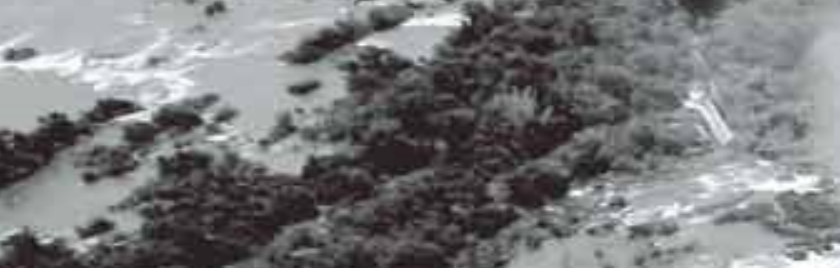

3.:

a -

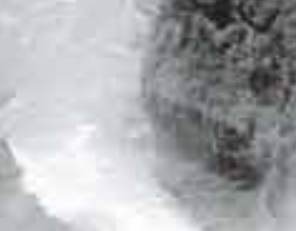

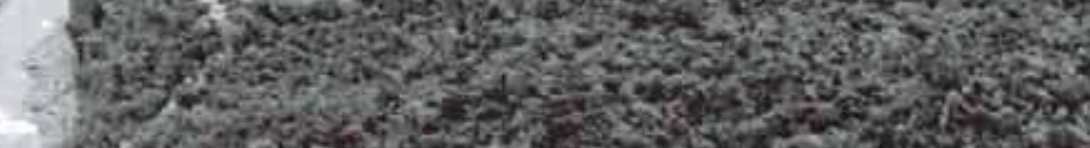

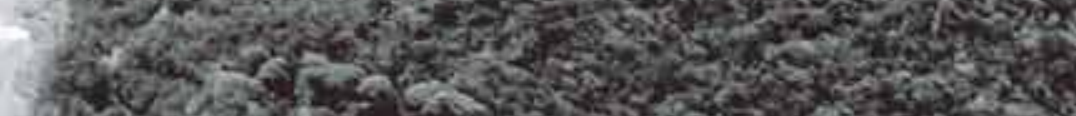

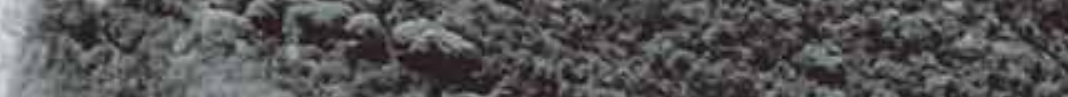
49.

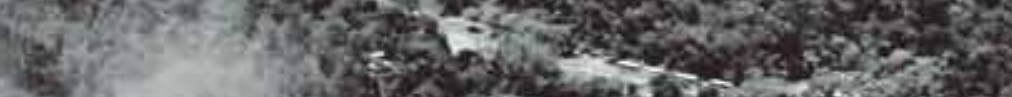
s.

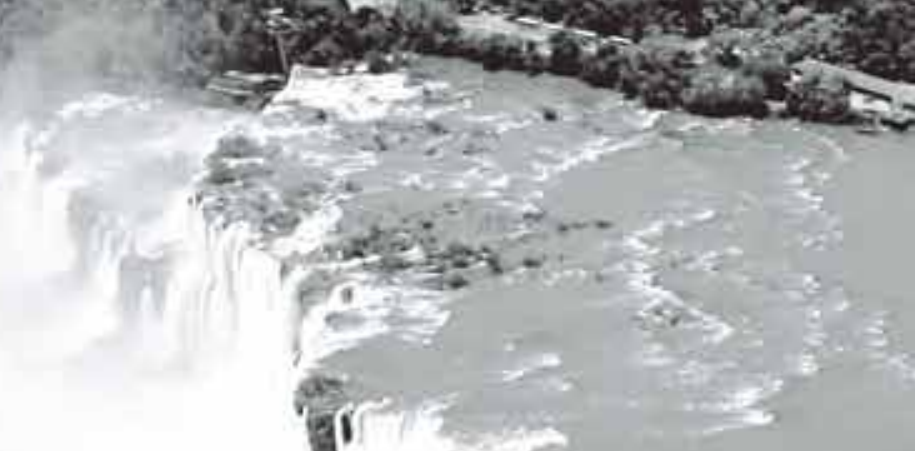

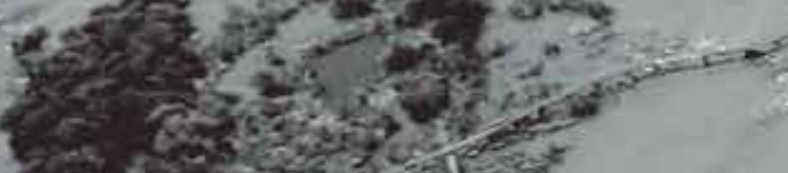

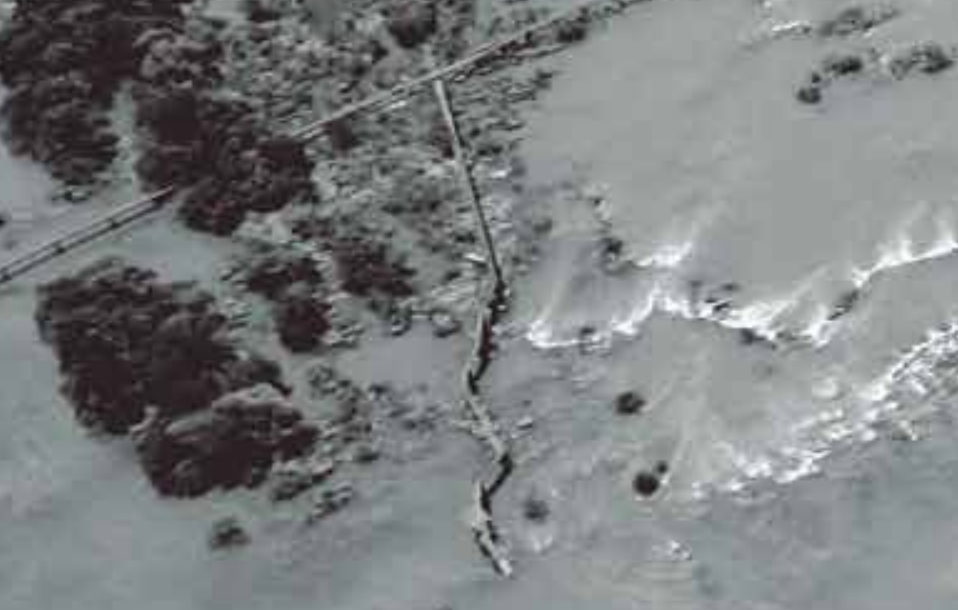

$+3$

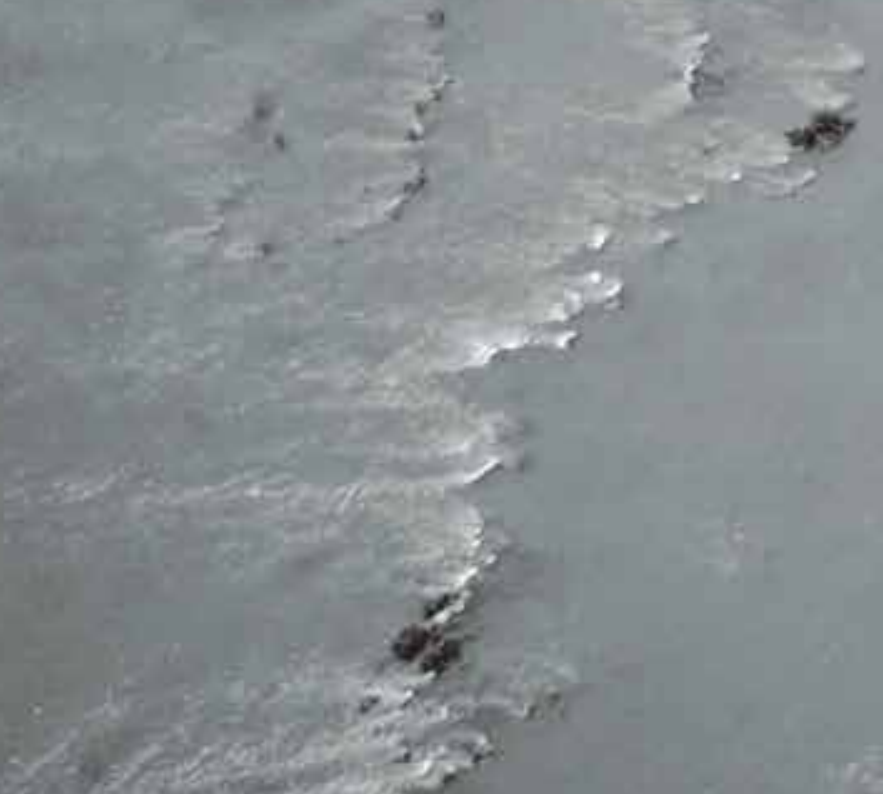

(2) 


\section{SUMÁRIO}

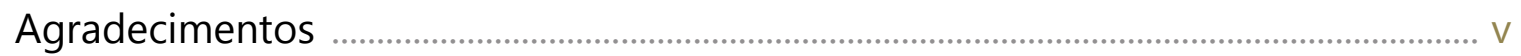

Epígrafe ..................................................................................................................................... vii

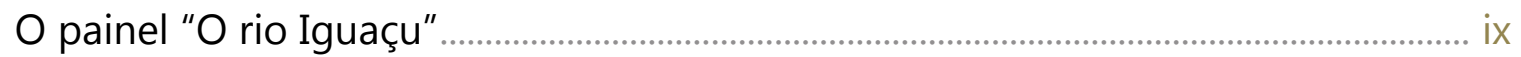

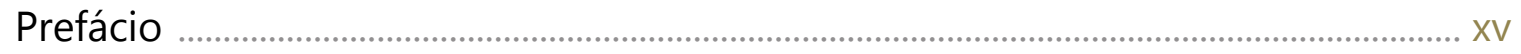

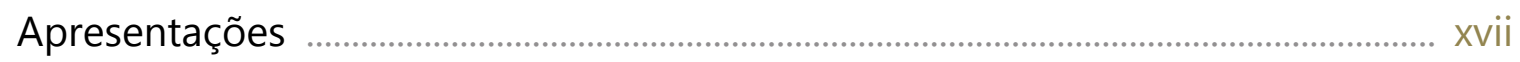

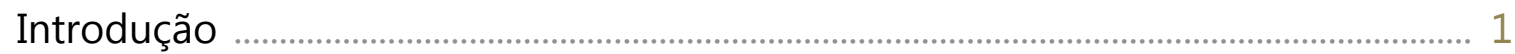

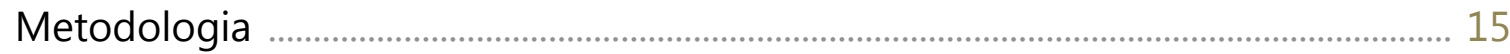

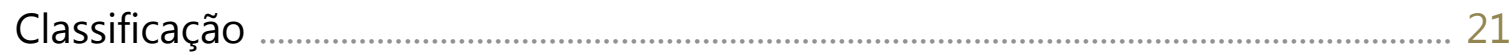

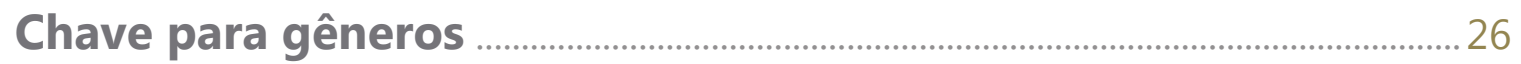

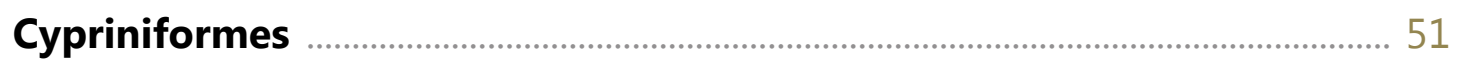

Cyprinidae, 53

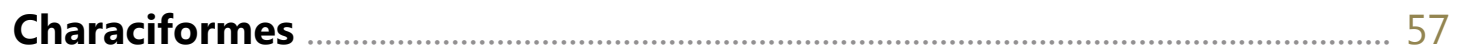

Parodontidae, 59

Curimatidae, 60

Prochilodontidae, 63

Anostomidae, 64

Crenuchidae, 70

Serrasalmidae, 72

Characidae, 73

Salmininae, 89

Bryconinae, 90

Stevardiinae, 92

Erythrinidae, 98

Siluriformes

Trichomycteridae, 103

Callichthyidae, 113

Loricariidae, 118

Neoplecostominae, 118

Hypoptopomatinae, 120 

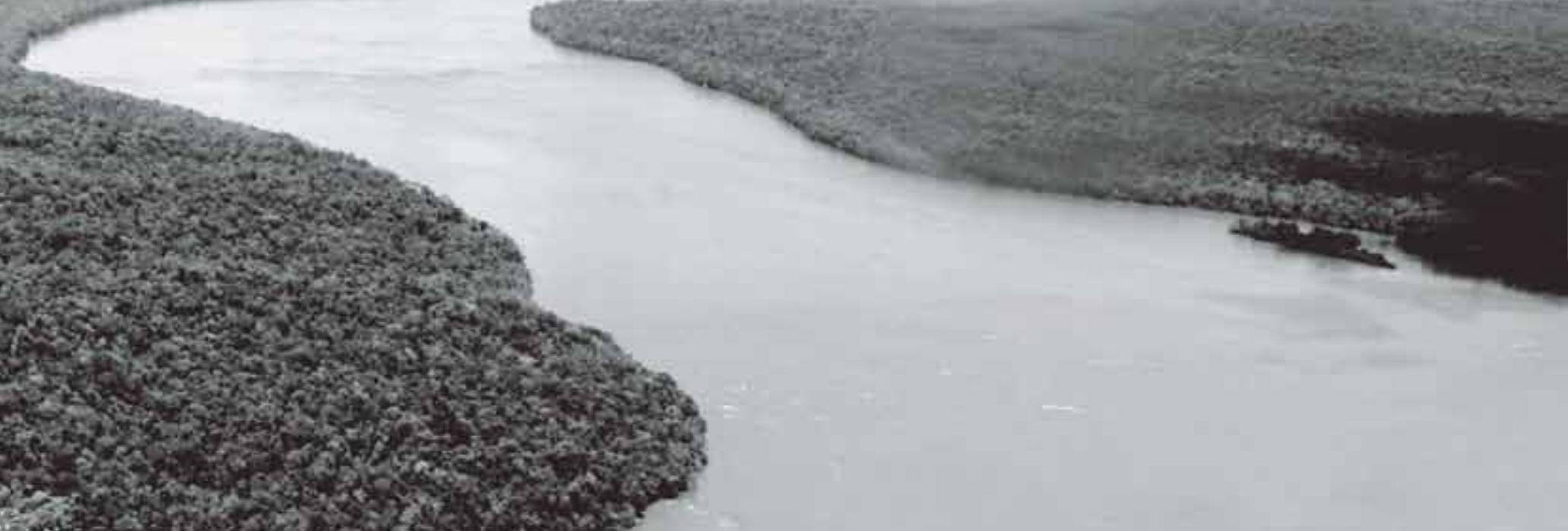

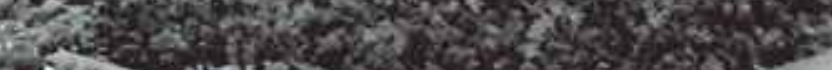

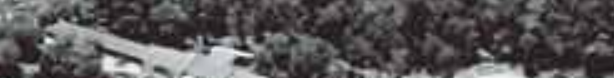

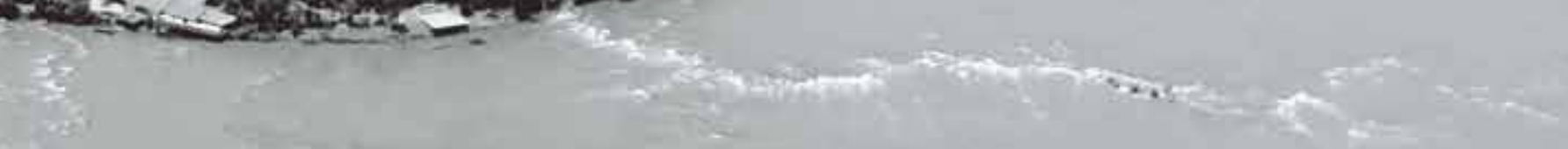

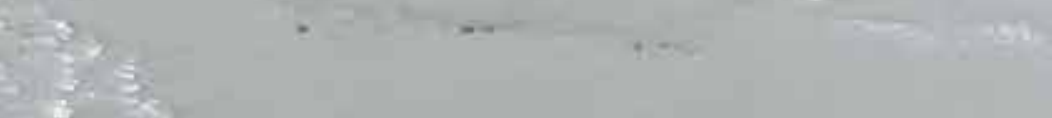

$\frac{-2}{3}$ 


\section{SUMÁRIO}

Loricariinae, 122

Hypostominae, 124

Heptapteridae, 132

Ictaluridae, 137

Auchenipteridae, 138

Clariidae, 140

Pimelodidae, 141

Gymnotiformes

Gymnotidae, 149

Apteronotidae, 150

\section{Atheriniformes}

Atherinopsidae, 155

Cyprinodontiformes

Poeciliidae, 159

Anablepidae, 161

Synbranchiformes

Synbranchidae, 167

\section{Perciformes}

Centrarchidae, 171

Cichlidae, 172

\section{Glossário}

Referências

Anexos

Anexo 1, 197

Anexo 2, 198

Anexo 3, 199

Anexo 4, 199 


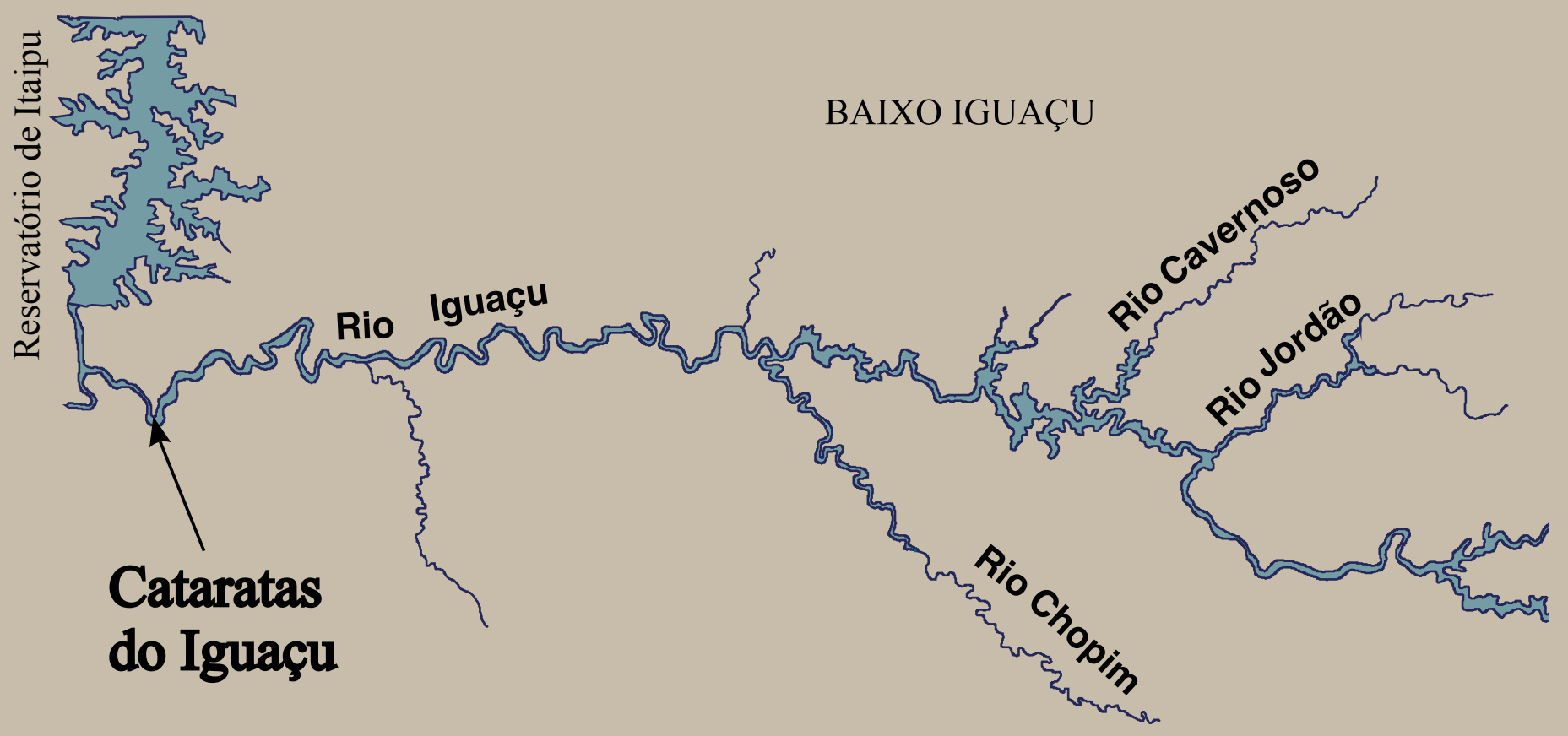

Mapa do rio Iguaçu e alguns tributários, com destaque para as Cataratas do Iguaçu e reservatório de Itaipu (adaptado de Júlio Júnior, Bonecker e Agostinho, 1997).

\section{Cataratas do Iguaçu}

As Cataratas do Iguaçu pertencem aos mais belos e famosos saltos do mundo. Com $1.200 \mathrm{~m}$ de largura acima das Cataratas, o rio Iguaçu estreitase até $\mathbf{6 5}$ a $100 \mathrm{~m}$ na fenda tectônica que forma o seu cânion. Contam-se ao todo $\mathbf{2 7 2}$ quedas isoladas, as quais, com as enchentes, formam uma única frente. $O$ lado brasileiro oferece a vista mais bela e complexa das Cataratas. Os governos brasileiro e argentino colocaram as Cataratas do Iguaçu sob proteção da natureza, sendo que o Parque Nacional do Iguaçu abrange no lado brasileiro uma grande área de mata nativa (Maack, 1981). 


\section{PREFÁCIO}

O rio Iguaçu, conhecido em todo mundo pelas belezas de suas Cataratas, tem, como demonstrado nesse livro, outra preciosidade que deve ser reconhecida como excepcional pela humanidade: a alta taxa de endemismo de sua ictiofauna. É mostrado que $70 \%$ das espécies de peixes nativas não são encontradas em qualquer outra parte do planeta. Isso, ao mesmo tempo em que se constitui num privilégio para a região, é também motivo de profunda preocupação. Extinções locais nessa bacia podem significar extinções globais, o que requer cuidados especiais nas ações praticadas na bacia.

É amplamente reconhecido na literatura que os fatores preponderantes na extinção de espécies em águas continentais são as alterações de habitats e introduções de espécies, seguidos pela poluição e exploração comercial dos recursos aquáticos. Infelizmente a ocupação da bacia do rio Iguaçu está entre as mais castigadas por esses fatores. Seus trechos alto e médio recebem enormes aportes de poluição urbana e industrial, enquanto o baixo trecho encontra-se modificado por reservatórios. Ao mesmo tempo, levantamentos realizados na bacia do rio Paraná demonstram que essa bacia comporta, proporcionalmente, o maior número de espécies introduzidas. A participação delas, como se verá na lista de espécies dessa obra, chega a quase $30 \%$ do total.

Embora a ictiofauna do rio Iguaçu originalmente não seja muito diversa, se comparada com outras sub-bacias do Paraná, é ainda surpreendentemente alta se considerado esse quadro de ocupação. Urge, no entanto, o conhecimento taxonômico dessas espécies e de suas demandas biológicas para que sejam protegidas e disponibilizadas para as próximas gerações. A presente obra representa um passo promissor nesse sentido. Ela coloca certa ordem nas prioridades de obtenção de subsídios para as ações de manejo e conservação da ictiofauna. O levantamento e a descrição das espécies devem preceder os estudos de ecologia, qualquer que seja o nível hierárquico considerado, especialmente no específico. O esforço despendido na busca do conhecimento bioecológico das espécies, empregado durante anos, tanto pelas concessionárias hidrelétricas como pelas universidades ou pesquisadores isolados, teriam sido mais efetivos se embasados em um conjunto de informações como o apresentado nesse volume. Há pouco mais de uma década as espécies mais abundantes no baixo rio Iguaçu sequer tinham nome. O gênero Astyanax comportava pelo menos metade do alfabeto como designação da espécie. Grande parte das informações ecológicas geradas permaneceu sem publicação durante anos pelo descompasso entre elas e o tempo e o esforço demandado na descrição das espécies. Em estudos ecológicos que tenham a população como unidade de trabalho a descrição da espécie e seu pronto reconhecimento são imprescindíveis.

Em resumo, o presente trabalho é uma iniciativa extremamente oportuna que demonstra a sensibilidade de seus autores e apoiadores para uma demanda urgente e imprescindível da conservação da diversidade de peixes de uma fauna única.

Prof. Dr. Ângelo Antônio Agostinho 


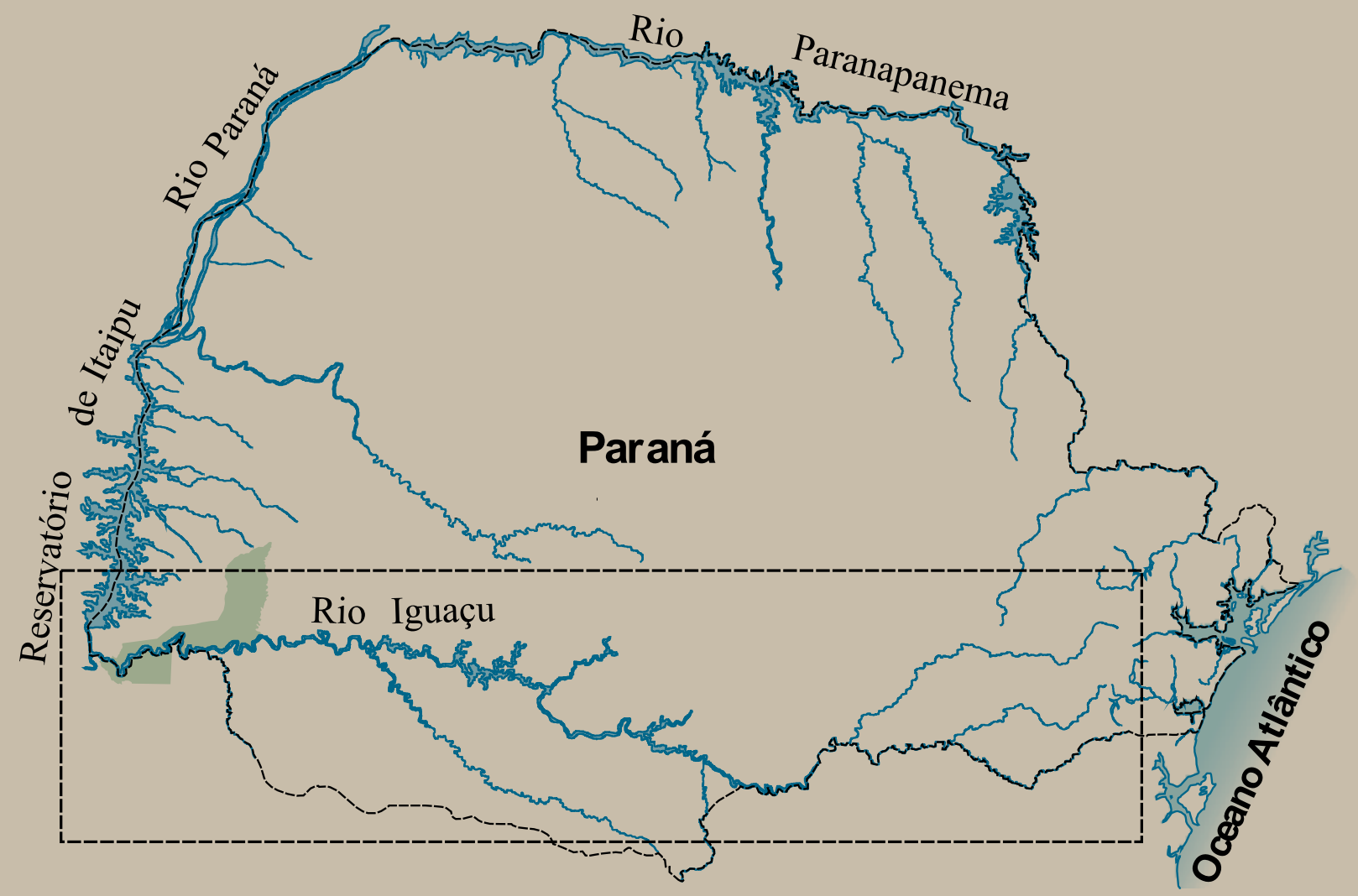

Mapa do Estado do Paraná, com destaque a localização do rio Iguaçu (por Jaime Luiz Lopes Pereira). 


\section{APRESENTAÇÕES}

Desenvolvimento e preservação ambiental são conceitos que podem e devem caminhar juntos para garantir o crescimento sustentável do nosso estado e país. O trabalho apresentado aqui deve ser valorizado por todos. Ele instrumenta a geração de conhecimentos que forneçam subsídios para a mitigação de impactos sobre a ictiofauna, bem como avaliações de projetos de preservação ambiental às espécies nativas e daquelas ameaçadas pela ação irracional do homem ou pelo simples crescimento populacional.

A realização de um estudo tão detalhado e aprofundado da bacia do Baixo Iguaçu garante aos pesquisadores, leitores, empresas e demais envolvidos uma lição de educação ambiental. Essa é mais do que necessária para entender a importância e a necessidade de preservar a natureza que deve ser feita por cada setor da sociedade. A consciência ambiental é o principal mecanismo para garantir o que chamamos de desenvolvimento sustentável.

Como entidade estadual protetora do meio ambiente, o Instituto Ambiental do Paraná não pode deixar de apoiar e destacar iniciativas e ações como essa. Elas garantem a disponibilidade de informações obtidas, garantindo a melhor compreensão possível sobre a ictiofauna, de modo que contribuam para o desenvolvimento de políticas públicas para a preservação da natureza e a pesca sustentável.

Esse catálogo não esgota o assunto que é constantemente atualizado com novidades. A visão que compartilho com os leitores é a realização de mais um estudo que mostra o desenvolvimento do estado sem promover a degradação do nosso meio ambiente. 


\section{APRESENTAÇÕES}

A Tractebel Energia, atenta às condições ambientais de suas áreas de atuação, vem promovendo ações que visam fomentar o conhecimento sobre os ecossistemas locais e desenvolver mecanismos que garantam a qualidade ambiental, através de programas de Pesquisa e Desenvolvimento, em parceria com renomadas instituições de pesquisa.

O desenvolvimento destas ações é compatível com as práticas de sustentabilidade adotadas pela Empresa, honrando a responsabilidade com o meio ambiente e o compromisso com as comunidades onde atua. Com esta filosofia, a Empresa utiliza os recursos naturais de forma responsável e promove a geração de conhecimento, o qual se torna público e passa a ser utilizado por universidades, instituições de pesquisa, entidades ambientais e pela comunidade em geral, ampliando sua inserção e podendo ser aplicado na promoção de melhores condições socioambientais.

O estudo da ictiofauna do Rio Iguaçu, em sua dimensão ecológica, demonstra-se fundamental para a sua conservação, considerando os aspectos biológicos e os indicadores embasados nos dados obtidos durante todos os anos de análise. Através desse estudo, a Empresa e suas partes interessadas passam a ter uma ferramenta para elaboração de projetos de conservação da biodiversidade local, além de possuir um importante banco de dados sobre o assunto no período estudado.

Para a Tractebel Energia, promover o desenvolvimento de pesquisas de ictiofauna, significa incentivar a geração de conhecimento de forma descentralizada e participativa, assegurando um vasto campo de estudo para acadêmicos e pesquisadores da área, aqui representados pela Universidade Estadual do Oeste do Paraná - UNIOESTE, que passam a utilizar os reservatórios das usinas hidrelétricas como grandes laboratórios, onde são compreendidos os fenômenos de forma ampla em seus próprios locais de ocorrência.

Através desta e de outras iniciativas semelhantes, a Tractebel Energia reafirma seu compromisso na difusão do conhecimento e na promoção da sustentabilidade. 
De todas as formas conhecidas de produzir energia elétrica na escala reclamada pelo crescimento do mercado consumidor, a mais econômica, a mais limpa e a de menor impacto ambiental é, com certeza, a força da água. Ou seja, além de insumo indispensável à manutenção da vida, a água é, para o sistema elétrico brasileiro, o principal e mais importante combustível.

A Copel, apoiada nos sólidos compromissos que tem com a sustentabilidade, entende que tem o dever de zelar pela higidez dos recursos hídricos que utiliza, atuando em favor da vida e do equilíbrio ambiental de rios e reservatórios.

Com tal objetivo, mantém programas permanentes voltados à qualidade da água, preservação e recomposição de matas ciliares e repovoamento de reservatórios, entre outros, a cargo da sua Diretoria de Meio Ambiente e Cidadania Empresarial.

$\mathrm{Na}$ condição de principal rio paranaense para fins de geração de eletricidade, o Iguaçu tem merecido atenção especial da Copel, que acumula e coloca em prática conhecimentos produzidos por décadas de estudos, pesquisas e ensaios de todos os aspectos e detalhes relacionados ao grande rio.

Para aprofundar as informações sobre a ictiofauna do rio Iguaçu, a Companhia instalou em 1992, na Usina Governador Ney Braga (Segredo), a Estação Experimental de Estudos Ictiológicos. Desde então, em parceria com várias instituições e com os dados que foram levantados ao longo dos anos, a Copel vem gerenciando de forma harmônica o equilíbrio da ictiofauna nos reservatórios do Iguaçu sob sua concessão.

Dessas observações resulta a constatação de que a ictiofauna do rio Iguaçu é pouco conhecida e altamente endêmica, o que aumenta a importância e confere um realce especial ao presente Catálogo no seu propósito de ajudar a preencher as lacunas existentes, constituindo-se em ferramenta importante para a identificação das espécies ocorrentes em diversos trechos do rio.

Sob a ótica do desenvolvimento sustentável, um vetor básico nas suas atividades, a parceria da Copel com a Universidade Estadual do Oeste do Paraná (Unioeste) para a elaboração do presente livro “Peixes do baixo rio Iguaçu" é uma demonstração exemplar de responsabilidade social e comprometimento com o equilíbrio ambiental.

Ao participar de iniciativas como esta, a Copel busca fomentar e promover a manutenção da biodiversidade através da difusão de conhecimentos, pois sem eles não há efetividade nas ações voltadas ao equilíbrio dos ecossistemas. 



\section{INTRODUÇÃO}

A bacia do rio Iguaçu localiza-se ao sul do Estado do Paraná, compreendendo 101 municípios, com uma população estimada de 4,5 miIhões de habitantes, dos quais 79,4\% correspondem à população urbana, sendo Curitiba, São José dos Pinhais, Colombo, Araucária, Pinhais, Guarapuava, Cascavel e Francisco Beltrão as cidades mais importantes situadas nesta bacia (SUPERINTENDÊNCIA DE DESENVOLVIMENTO E RECURSOS HÍDRICOS E SANEAMENTO AMBIENTAL, 1997; INSTITUTO PARANAENSE DE DESENVOLVIMENTO ECONÔMICO E SOCIAL, 2010). No alto Iguaçu, onde se situa a região metropolitana de Curitiba, existe uma grande concentração populacional, com atividades industriais, comerciais e de serviços, enquanto que no médio e baixo Iguaçu predomina a agropecuária, sendo as culturas de soja e trigo as com maior destaque (SUPERINTENDÊNCIA DE DESENVOLVIMENTO E RECURSOS HÍDRICOS E SANEAMENTO AMBIENTAL, 1997).

O rio Iguaçu é, entre os rios paranaenses, o de maior bacia hidrográfica, abrangendo uma área de aproximadamente $72.000 \mathrm{~km}^{2}$, da qual 79\% pertencem ao Estado do Paraná, 19\% ao Estado de Santa Catarina e $2 \%$ à Argentina (ELETROSUL, 1978). Considerando a confluência dos rios Atuba e Iraí como seu ponto de origem, seu desnível é de $830 \mathrm{~m}$, ou seja, da altitude de $908 \mathrm{~m}$ nessa localidade até os $78 \mathrm{~m}$ na sua desembocadura no rio Paraná. Com direção geral leste-oeste, percorre $1.060 \mathrm{~km}$ desde suas nascentes na vertente ocidental da Serra do Mar, até a foz, no rio Paraná (PAIVA, 1982).

A formação da bacia hidrográfica do rio Iguaçu remonta a era mesozóica e início da paleozóica (MINEROPAR, 2010), e foi associada a movimentos escalonados do soerguimento da Serra do Mar (HAUCK, 2009), dando origem aos três planaltos paranaenses: $1^{\circ}$ ) região de Curitiba; $2^{\circ}$ ) região de Ponta Grossa, e $3^{\circ}$ ) região de Guarapuava (MAACK, 2001). A partir dessas características geomorfológicas, o rio Iguaçu foi também subdividido em três regiões, o alto Iguaçu, região do $1^{\circ}$ planalto, o médio Iguaçu, região do $2^{\circ}$ planalto, e o baixo Iguaçu, região do $3^{\circ}$ planalto. 


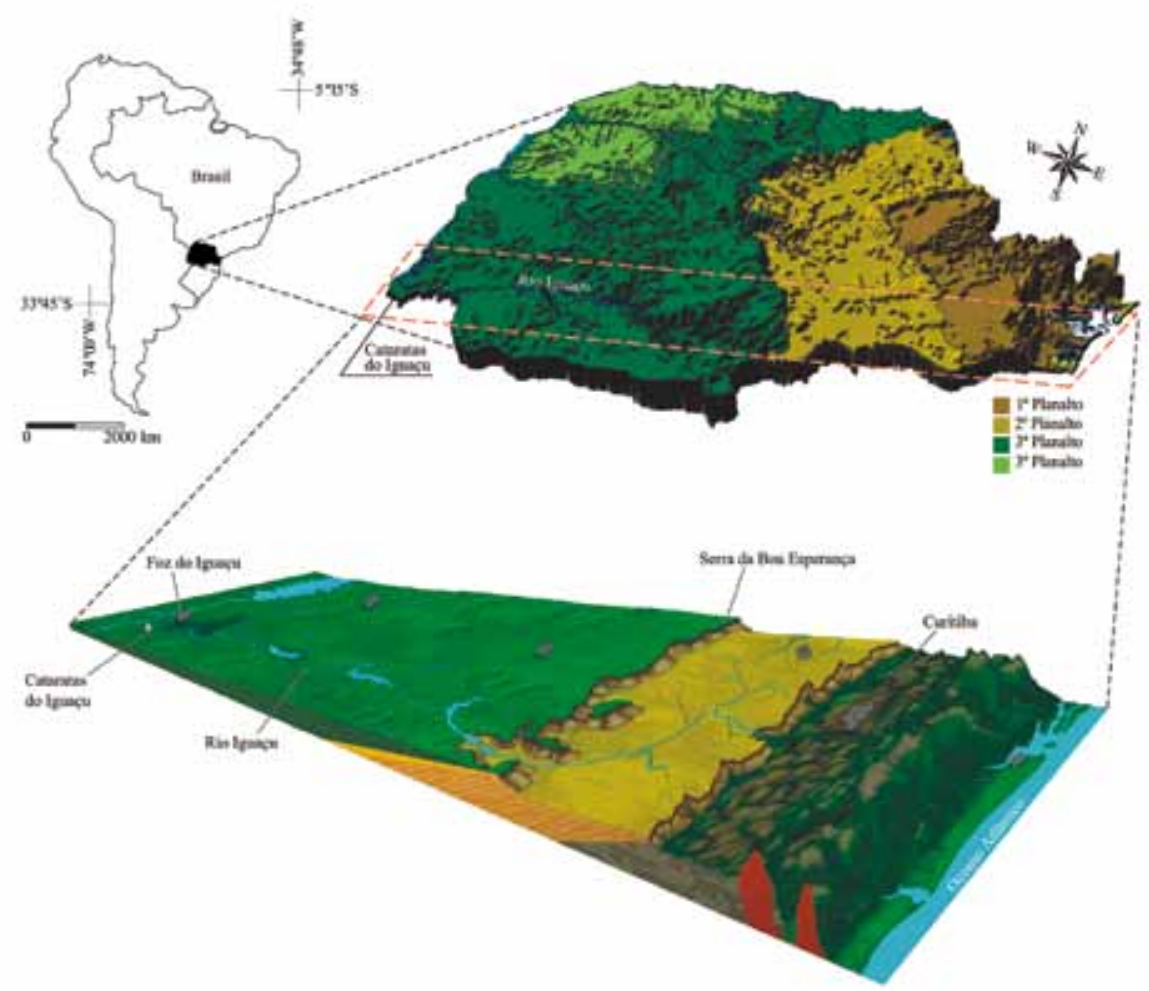

Perfil estratigráfico do território e divisão dos planaltos paranaenses, adaptado de Mineropar (2010).

Segundo Ingenito, Duboc e Abilhoa (2004), o alto Iguaçu não possui definição formal de seus limites, sendo aceito que compreenda o trecho desde suas nascentes, em Curitiba, até o início de suas corredeiras no município de Porto Amazonas. Esta região está localizada na divisa entre o primeiro e o segundo planaltos paranaenses, onde o rio Iguaçu corta a escarpa devoniana, em um longo trecho de corredeiras, que se inicia com uma queda de nove metros, conhecida como Salto Caiacanga (MAACK, 1981). O médio Iguaçu, embora não tenha seus limites estabelecidos na literatura, é aqui considerado como o trecho entre Porto Amazonas e União da Vitória, incluindo o rio Negro e seus afluentes, que pertencem ao segundo planalto paranaense. A partir de União da Vitória inicia-se o baixo Iguaçu (objeto deste estudo), que era caracterizado pela presença de inúmeras cachoeiras, como a de Salto Grande (13 m), Salto Santiago (40 m), Salto Osório (30 m) e as Cataratas do Iguaçu (72 m) (MAACK, 1981), que deram origem a vários reservatórios, terminando em sua desembocadura no rio Paraná. 
Sua fisiografia original apresentava variações marcantes durante o percurso. No primeiro planalto, apresenta meandros com amplas curvaturas e extensas várzeas, características que lhe conferem aspecto senil. Sua entrada no segundo planalto, através da escarpa devoniana, entre Engenheiro Bley e Porto Amazonas, o transforma em rio de grandes corredeiras (MAACK, 1981). Segundo este mesmo autor, entre os principais afluentes deste trecho, destacam-se os rios Piraquara, Miringuava e Maurício, na margem esquerda, e Palmital, Passa Una e Papagaio, na direita.

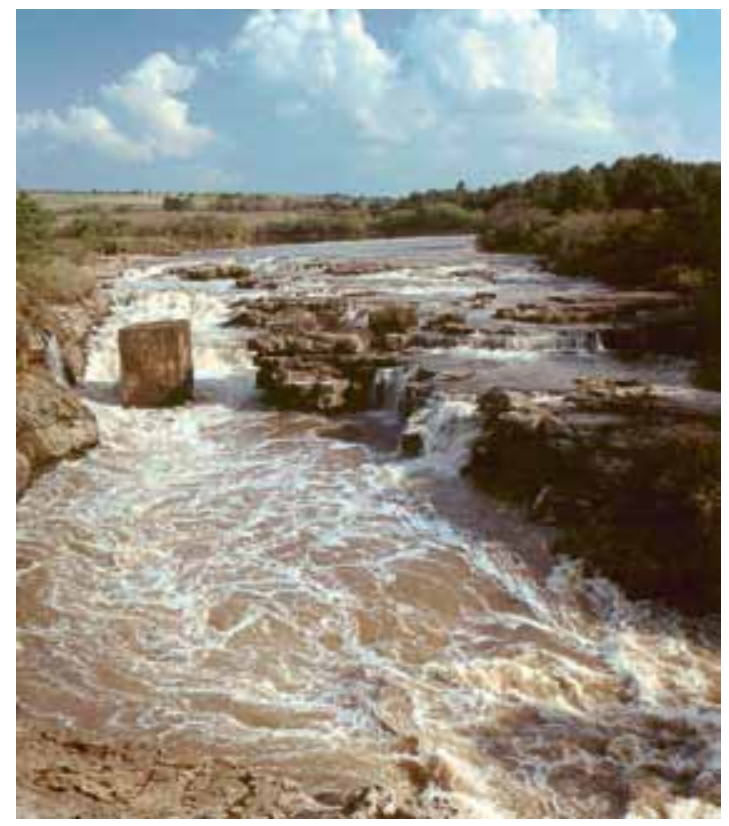

Salto Caiacanga

(foto cedida por Leonardo Ingenito).

A partir de Porto Amazonas até União da Vitória, ainda no segundo planalto, o rio Iguaçu volta a apresentar características senis, com frequentes meandros e várzeas. Nesse trecho destacam-se os rios Potinga e Claro, na margem direita, e Passa Dois, Negro e Timbó, na esquerda. Abaixo de União da Vitória, o rio atravessa a escarpa mesozóica do terceiro planalto (Serra da Boa Esperança) e apresentava, antes dos represamentos que ocuparam a maior parte desse trecho, um aspecto rejuvenescido, marcado por inúmeras pequenas corredeiras e cachoeiras (MAACK, 1981). Segundo este mesmo autor, nesse trecho da bacia, os rios Jangada, Iratim, Chopim, Capanema e Santo Antônio são os principais tributários da margem esquerda, e Areia, Jordão, Cavernoso, Guarani, Adelaide, Tormenta, Andrada e Gonçalves Dias, os da margem direita.

Na região das cataratas, no Parque Nacional do Iguaçu, o rio tem uma largura aproximada de $1.200 \mathrm{~m}$ e vazão média de $1.800 \mathrm{~m}^{3} / \mathrm{s}$, correndo, no restante de seu curso, em um profundo cânion, até o rio Paraná (MAACK, 1981), com um desnível de apenas sete metros. 


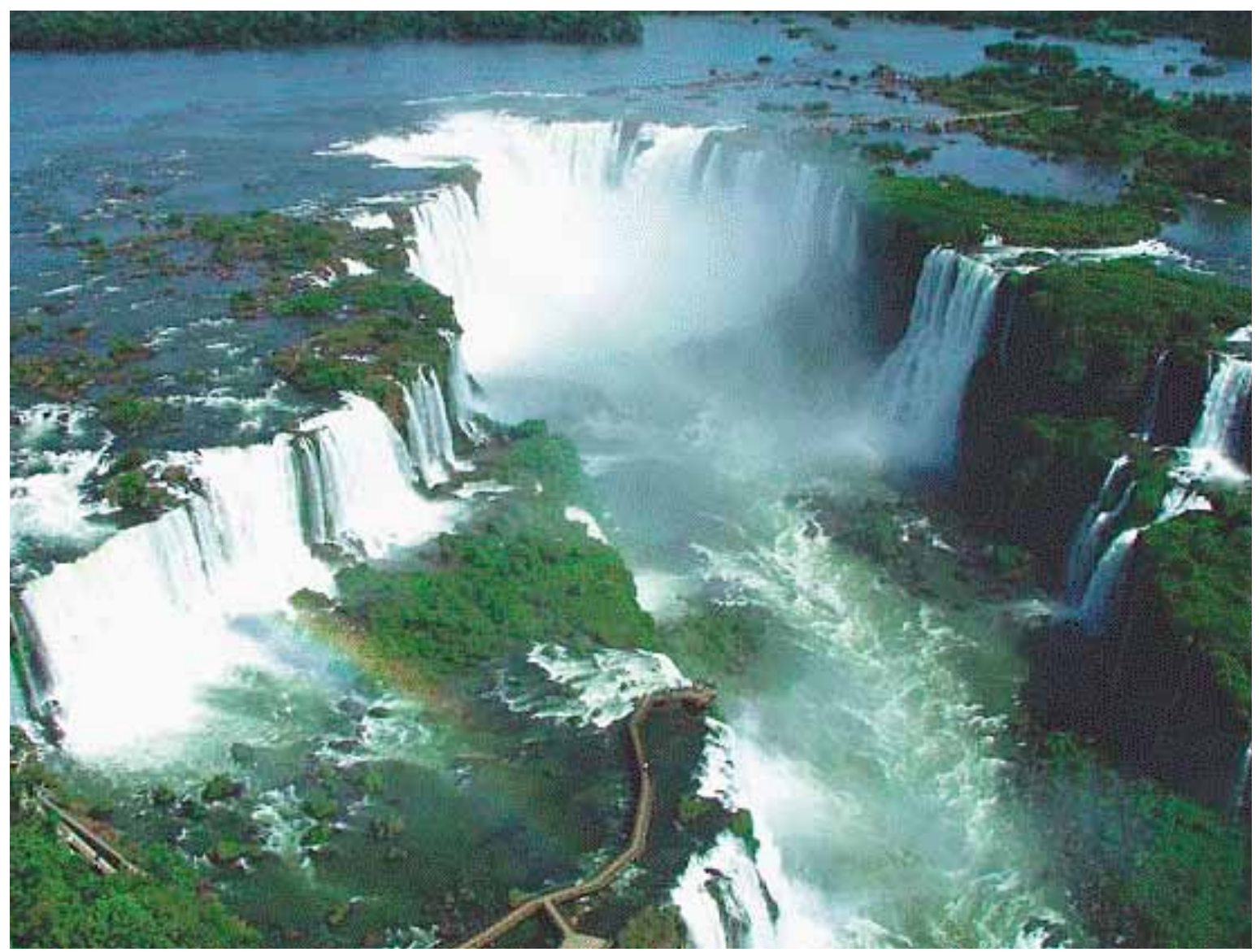

Cataratas do Iguaçu

(foto cedida por Apolônio Rodrigues).

A bacia do rio Iguaçu apresenta clima subtropical úmido, mesotérmico, com verão quente, sem estação seca no inverno. Ao longo de sua extensão, abrange regimes térmicos distintos: (i) até a metade oriental do terceiro planalto, as temperaturas dos meses mais quentes são inferiores a $22^{\circ} \mathrm{C}$, registrando-se mais de cinco geadas por ano; (ii) no trecho inferior restante, as temperaturas dos meses mais quentes superam $22^{\circ} \mathrm{C}$ e são registradas, no máximo, três geadas por ano (MAACK, 1981). As precipitações médias anuais na bacia hidrográfica do rio Iguaçu são de $1.700 \mathrm{~mm}$ no primeiro planalto, $1.800 \mathrm{~mm}$ no segundo planalto e de $1.900 \mathrm{~mm}$ no terceiro planalto (AZEVEDO, 2006).

Esta bacia teve seus cursos de água enquadrados pela portaria 020/92 (SUREHMA, 1992). Deste modo, no que se refere à qualidade da água, quase todos os cursos de água da bacia do rio Iguaçu foram enquadrados como de Classe 2, exceto os situados dentro dos limites de tombamento da Serra do Mar e da área de especial interesse 
turístico Marumbi, rio Papagaios e seus afluentes. Estes foram enquadrados na classe especial, e os cursos de água localizados no Parque Nacional do Iguaçu, rio Gonçalves Dias e seus afluentes, rio São João e seus afluentes, rios Ampere, Herval, Jacutinga, Itaqui, Matadouro, Peroba, Saltinho, das Flores, Passo Liso, Brinco, Jirau Alto, Jaracatiá, Avestruz, Serra, Calixto, Stingem, Piripau, Bragas, Leão, Curral das Éguas, Areia Branca, Passinho, Vila Nova, Santa Cruz, Santana, Barreiro, Cascalhal, Faxinal (município de Rio Azul), das Antas, Faxinal (município de São Jorge do Oeste), Trigolândia, Rodeio e Tigre foram enquadrados como de Classe 1. Os rios Belém, Barigui e Cambuí pertencem à Classe 3 (SUREHMA, 1992).

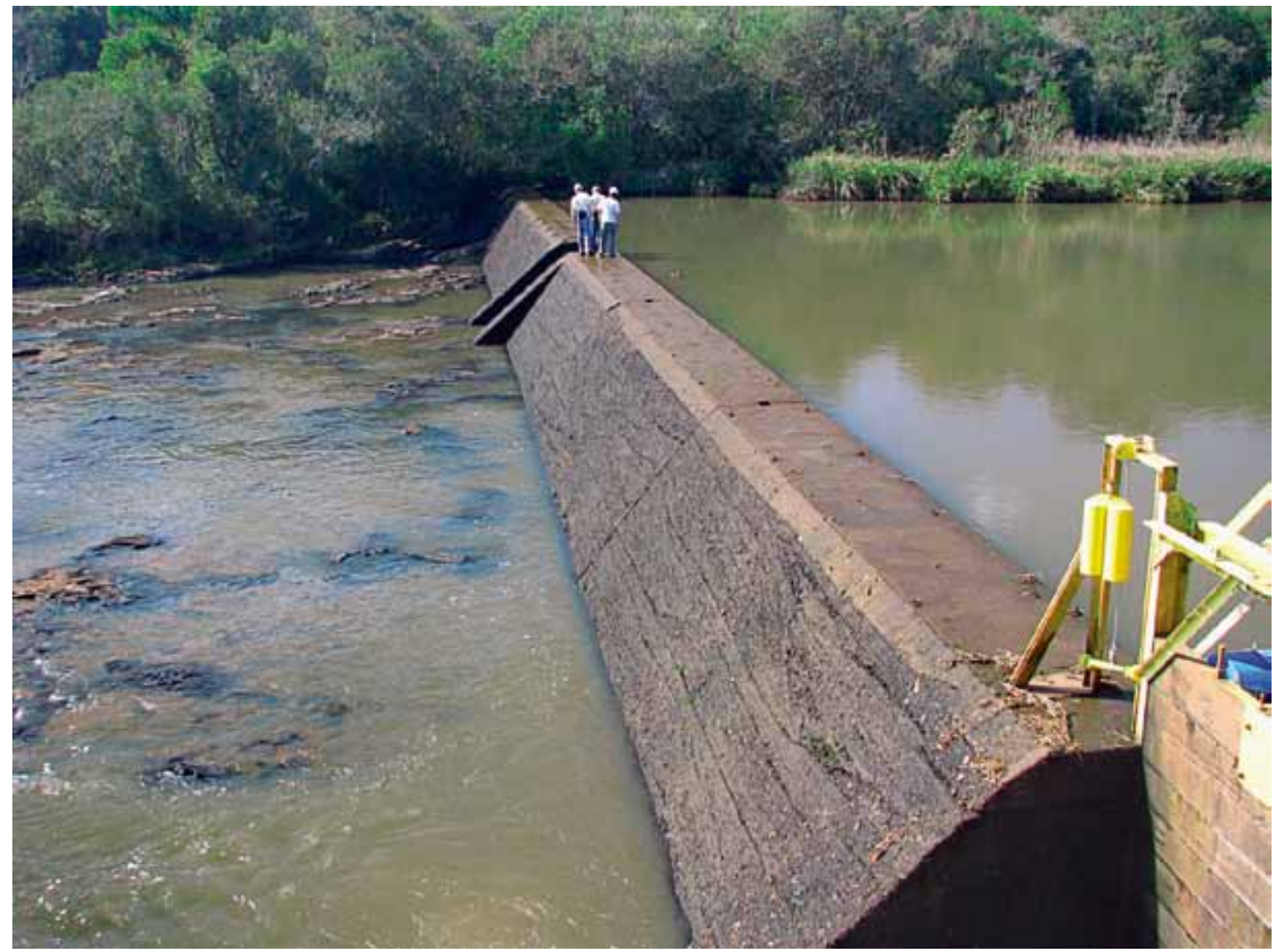




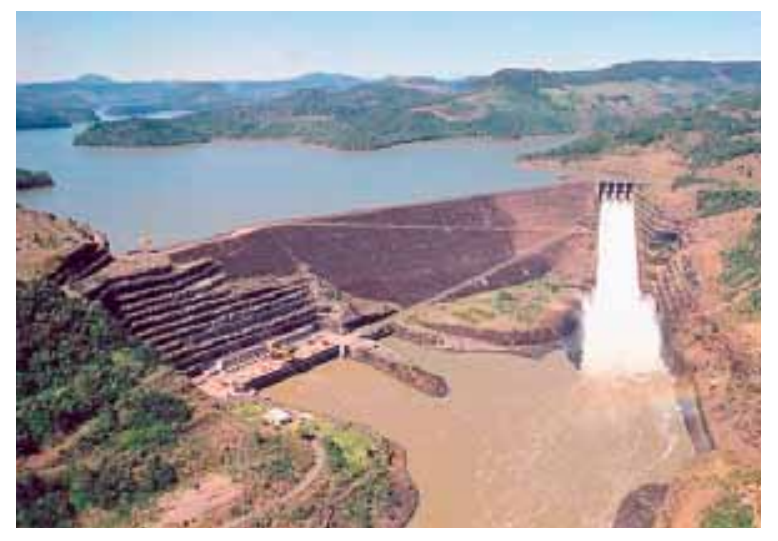

Usina Hidrelétrica de Foz do Areia (foto cedida pela Copel).

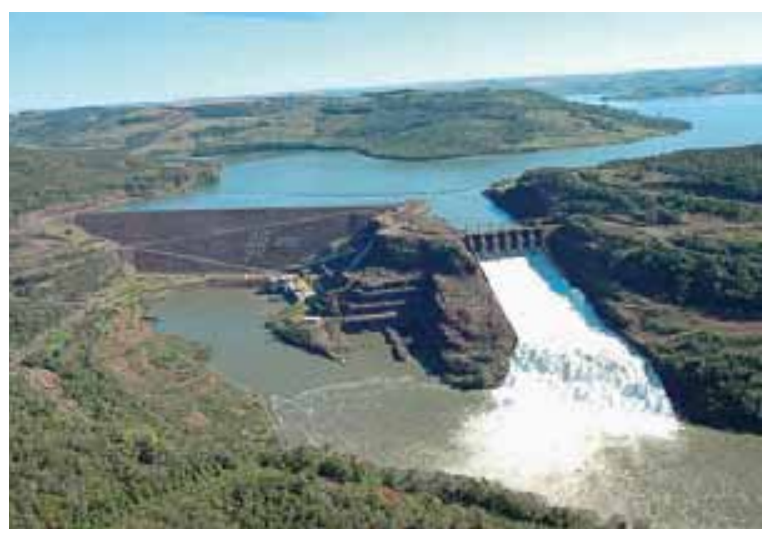

Usina Hidrelétrica de Segredo (foto cedida pela Copel).

O elevado desnível da bacia do rio Iguaçu no terceiro planalto se constituiu em grande atrativo para o aproveitamento hidrelétrico, resultando em cinco grandes reservatórios e vários pequenos, que alteraram notavelmente seus atributos físicos, químicos e biológicos. Assim, os grandes represamentos construídos nos últimos 36 anos transformaram as corredeiras e saltos anteriormente presentes entre União da Vitória e Salto Caxias, em uma sequência de reservatórios que alagam $656 \mathrm{~km}^{2}$. Esses aproveitamentos são responsáveis por cerca de 22,5\% de toda energia hidrelétrica produzida no Estado do Paraná, incluindo aquela gerada pela Itaipu Binacional ( $42,5 \%$, se excluída a de Itaipu). Os principais reservatórios da calha do Iguaçu ocupam $41 \%$ de seu curso total (JÚLIO JÚNIOR; BONECKER; AGOSTINHO, 1997).

Devido às suas características geomorfológicas e morfodinâmicas e às relações com sua hidrografia, o cenário da bacia hidrográfica do Iguaçu é considerado como de elevada importância ecológica. Está localizada em uma região de relevo acidentado, que forma diversos rios e cachoeiras, influenciando enormemente a distribuição geográfica de espécies, destacando-se entre elas, as de peixes.

As cataratas do Iguaçu parecem ter exercido um isolamento geográfico eficaz para a ictiofauna do rio Iguaçu, o que proporcionou o elevado grau de endemismo de sua ictiofauna. Na década de 90 , esse rio teve o caráter endêmico da fauna de peixes estimado em $75 \%$ do total das espécies (ZAWADZKI; RENESTO; BINI, 1999), que vem sendo reduzido ao longo dos anos, principalmente devido a ações antrópicas, como a introdução de espécies não nativas (BAUMGARTNER; BAUMGARTNER; PAVANELLI; SILVA; FRANA; OLIVEIRA; MICHELON, 2006), 
tornando os riscos de extinção de proporções globais eminentes (UNIVERSIDADE ESTADUAL DE MARINGÁ, 2002). Assim, qualquer perda nessas circunstâncias constituiria um evento irremediável. A ictiofauna da bacia do rio Iguaçu apresenta tal peculiaridade que permitiu sua caracterização como uma ecoregião separada da bacia do rio Paraná, por um trabalho que analisou espécies de peixes e suas distribuições em toda a biosfera (ABELL; THIEME; REVENGA; BRYER; KOTTELAT; BOGUTSKAYA; COAD; MANDRAK; CONTRERAS BALDERAS; BUSSING; STIASSNY; SKELTON; ALLEN; UNMACK; NASEKA; REBECCA; SINDORF; ROBERTSON; ARMIJO; HIGGINS; HEIBEL; WIKRAMANAYAKE; OLSON; LÓPEZ; REIS; LUNDBERG; SABAJ PÉREZ; PETRY, 2008).

Apesar de sua grande importância ecológica, a ictiofauna da bacia vem sendo pouco estudada, apresentando problemas de ordem taxonômica e, mais que isso, a obtenção de novos dados acerca dessa fauna encontra-se ameaçada pela intensa ocupação antrópica (UNIVERSIDADE ESTADUAL DE MARINGÁ, 2002) e consequente mudança da paisagem local para o desenvolvimento regional. A busca de informações acerca dessa fauna passou a ser primordial, o que tem proporcionado um aumento no número de espécies encontradas na bacia. Os primeiros trabalhos envolvendo espécies do rio Iguaçu foram conduzidos por Hasemann (1911a, 1911b), que descreveu 13 espécies de peixes em sua expedição ao rio Iguaçu para descrição de espécies da flora e fauna. Severi e Cordeiro (1994) encontraram 47 espécies em um catálogo de peixes da bacia, seguidos por Garavello, Pavanelli e Suzuki (1997), que encontraram 52 espécies na região do reservatório de Segredo. Baumgartner, Baumgartner, Pavanelli, Silva, Frana, Oliveira e Michelon (2006) registraram 41 espécies na área de influência do reservatório

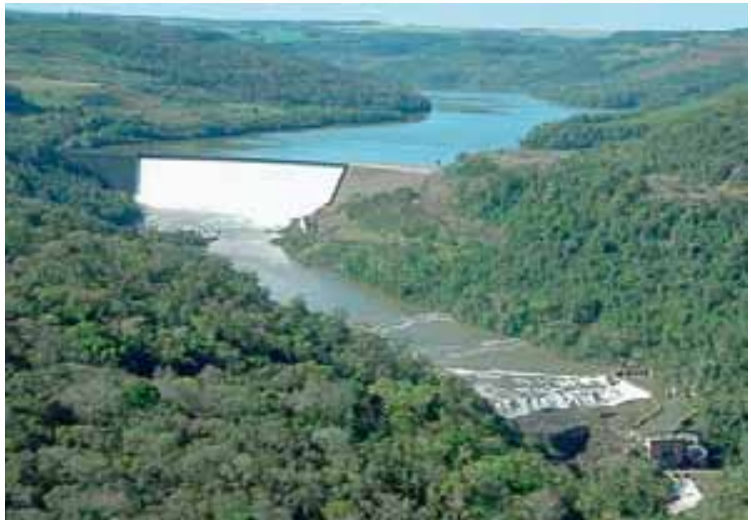

Usina Hidrelétrica de Foz do Jordão (foto cedida pela Copel).

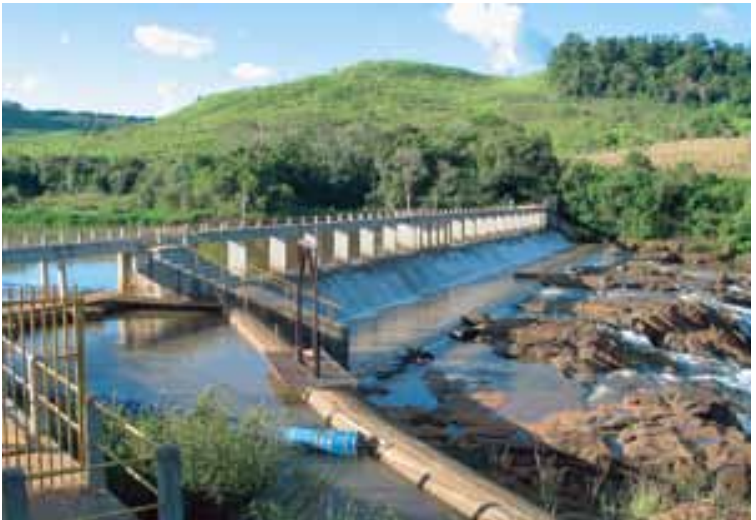

Usina Hidrelétrica do Cavernoso (foto cedida pela Copel). 
(3)

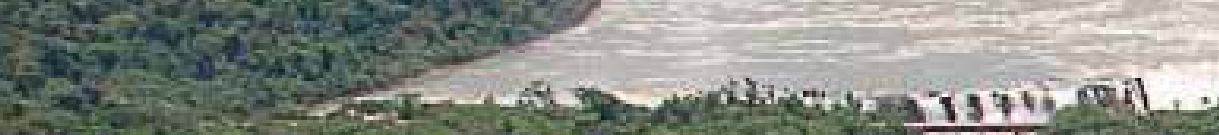

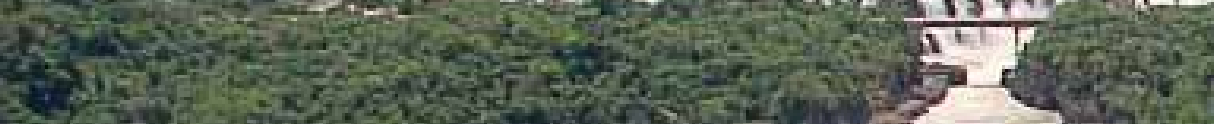
. 

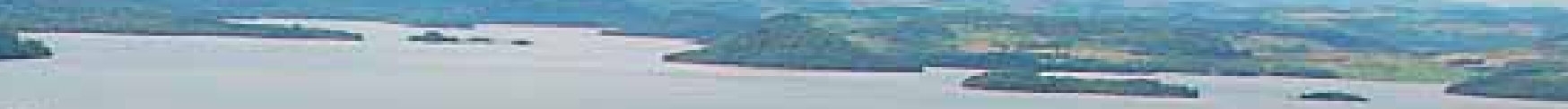

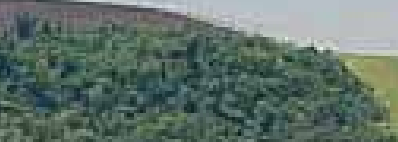

7.

- 1 (1)

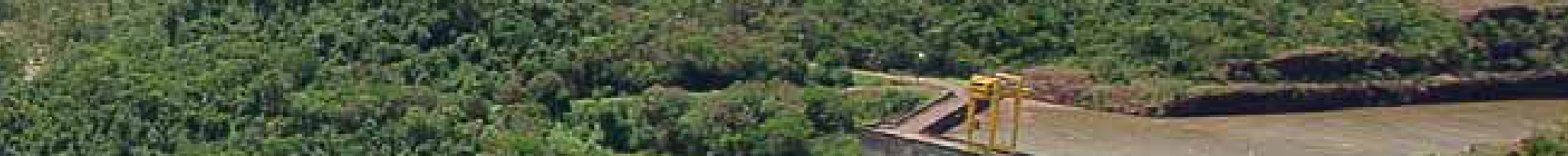

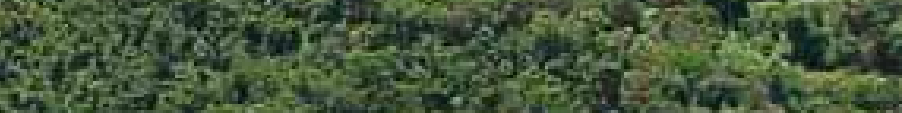

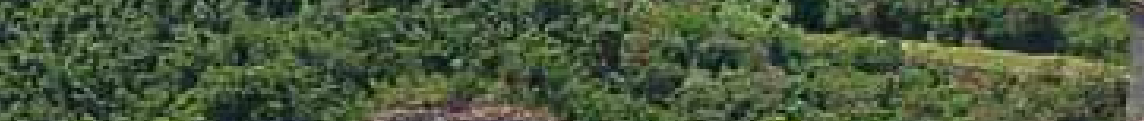

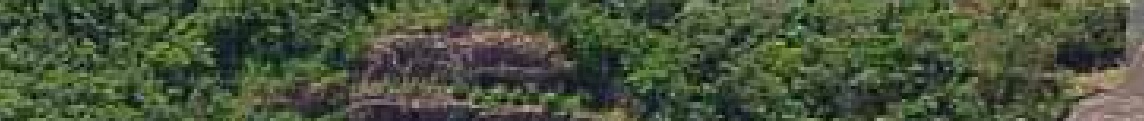
(2)

Q

H.

P.

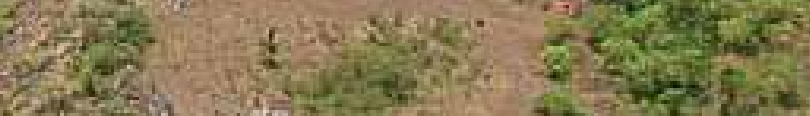

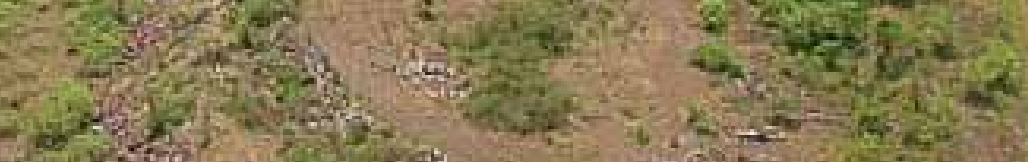

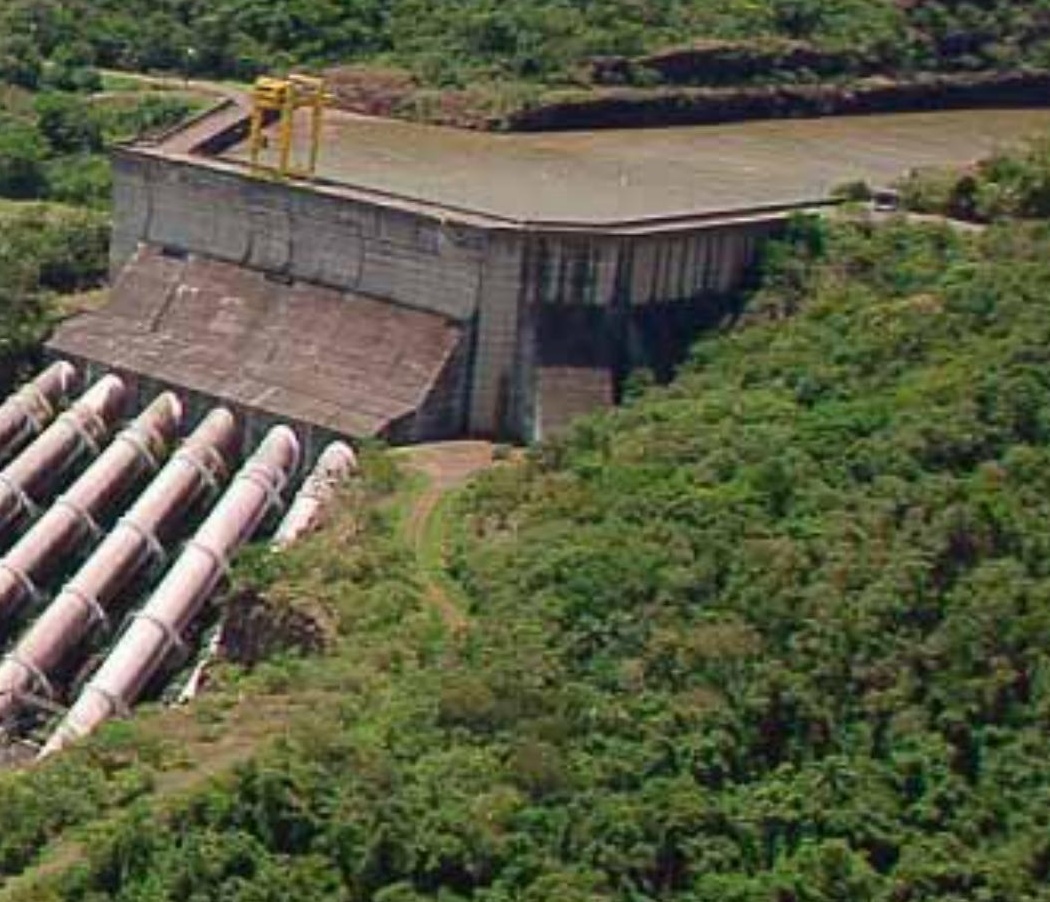

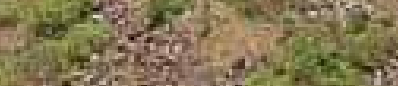

10.

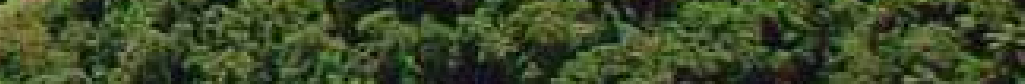

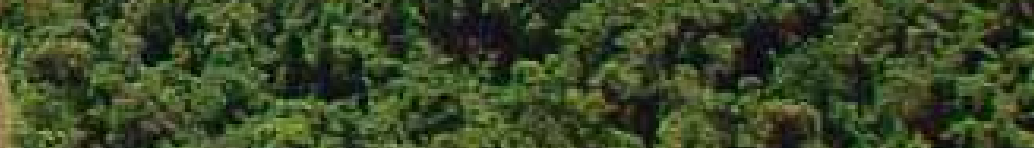

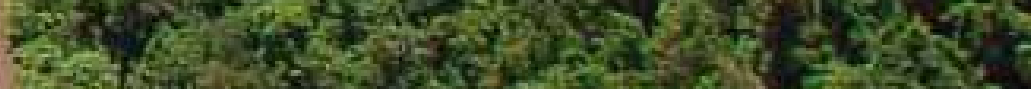

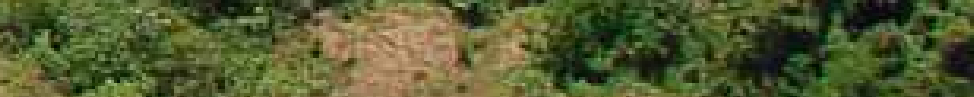

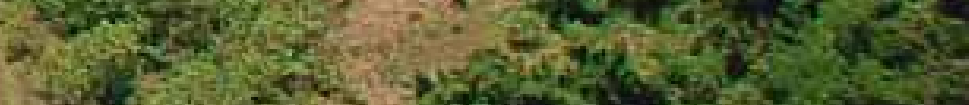

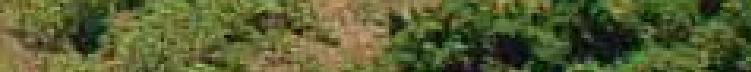
(25)

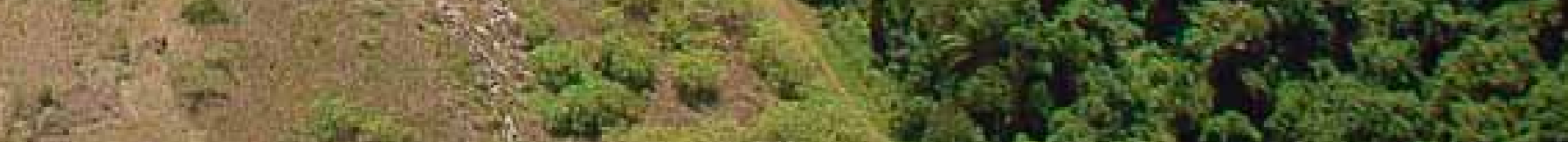


de Salto Osório, e Ingenito, Duboc e Abilhoa (2004), além de registrar 41 espécies em seu estudo de peixes da região do alto Iguaçu, relataram a existência de 84 espécies conhecidas nessa bacia hidrográfica. Infelizmente, um porcentual crescente destas refere-se a espécies não indígenas que têm sido capturadas na bacia por causas distintas.

Devido à grande importância em inventariar sua fauna de peixes, diversos pesquisadores isoladamente também vêm contrinbuindo nos últimos anos para o aumento no conhecimento da ictiofauna do Iguaçu. Neste contexto, podem ser destacados os trabalhos de Pinna (1992), Reis (1997), Wosiacki (1997), Lucinda e Garavello (2001), Almirón, Azpelicueta e Casciotta (2002), Azpelicueta, Casciotta e Almirón (2002, 2003), de Pinna e Wosiacki (2003), Vitule e Abilhoa (2003), Almirón, Azpelicueta e Casciotta (2004), Casciotta, Almirón e Azpelicueta (2004), Wosiacki e Garavello (2004), Garavello (2005), Haluch e Abilhoa (2005), Casciotta, Almirón e Gómez (2006a, 2006b), Kullander e Ferreira (2006), Lucinda, Ghedotti e Graça (2006), Bifi, Baumgartner, Baumgartner, Frana e Debona (2006), Buitrago-Suárez e Burr (2007), Garavello e Shibatta (2007), Wosiacki e de Pinna (2007), Casciotta e Almirón (2008), Ingenito, Ghazzi, Duboc e Abilhoa (2008), Wosiacki e de Pinna (2008a, 2008b), Alcaraz, Pavanelli e Bertaco (2009), Bifi, Pavanelli e Zawadzki (2009), Pavanelli e Bifi (2009), Pavanelli e Oliveira (2009) e Garavello e Sampaio (2010).

Os autores desse catálogo buscaram produzir uma obra sintetizada, sistematizada, especializada e atualizada que aglutine informações taxonômicas das espécies de peixes da região do baixo rio Iguaçu, o que até o momento era inexistente. Com o objetivo de facilitar a identificação da ictiofauna pela comunidade científica, estudantes, pescadores, leigos interessados, gestores das áreas ambiental, turística e empresarial, foram inventariadas e redescritas 106 espécies de peixes, incluindo as não indígenas, sendo apresentadas chaves para identificação das espécies, suas características morfológicas e merísticas, fotos, dados biológicos, estado de conservação, endemismo, porte, ocorrência e status taxonômico de cada espécie. 


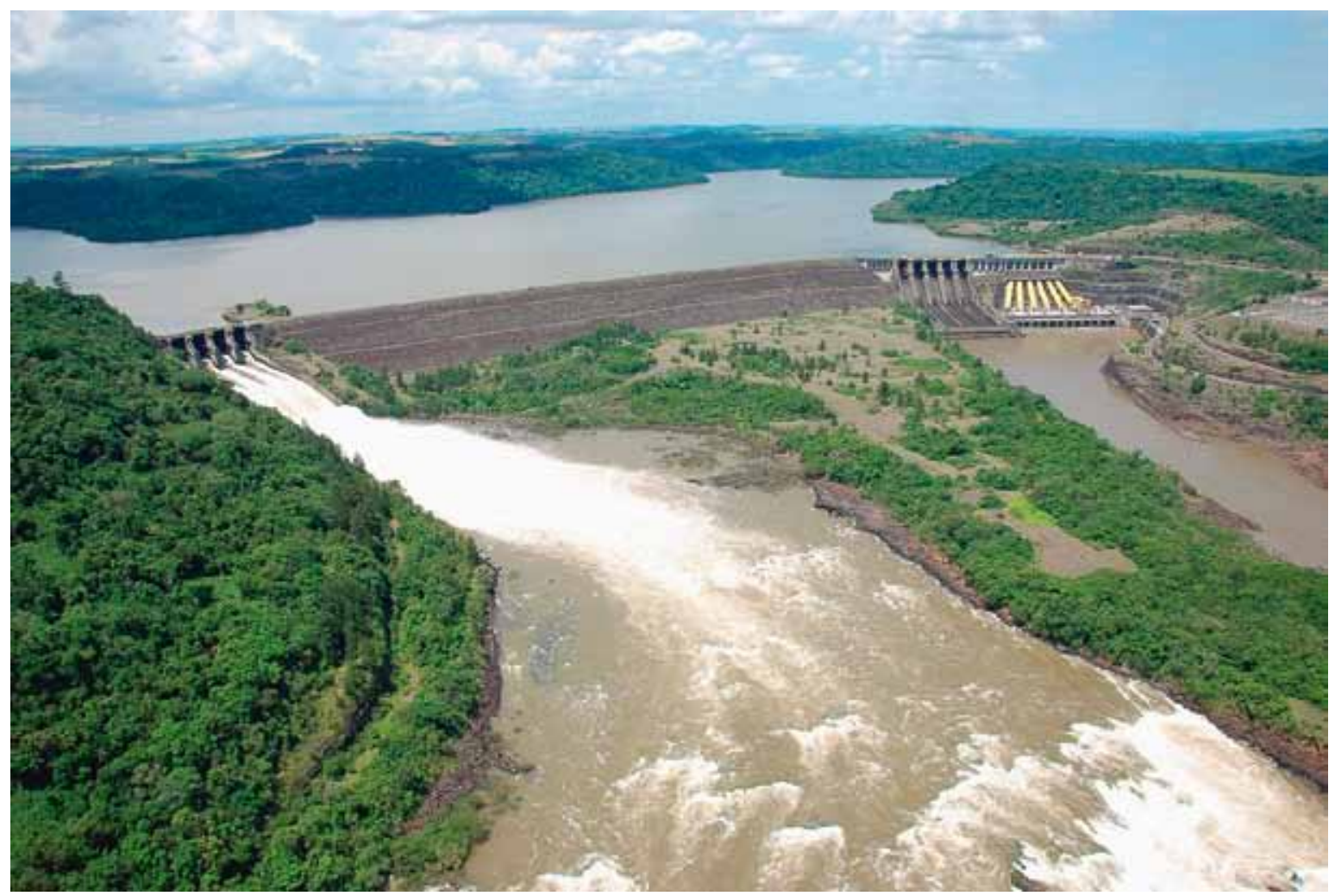

Usina Hidrelétrica de Salto Osório

(foto cedida por Marcos Aurélio Zanella).

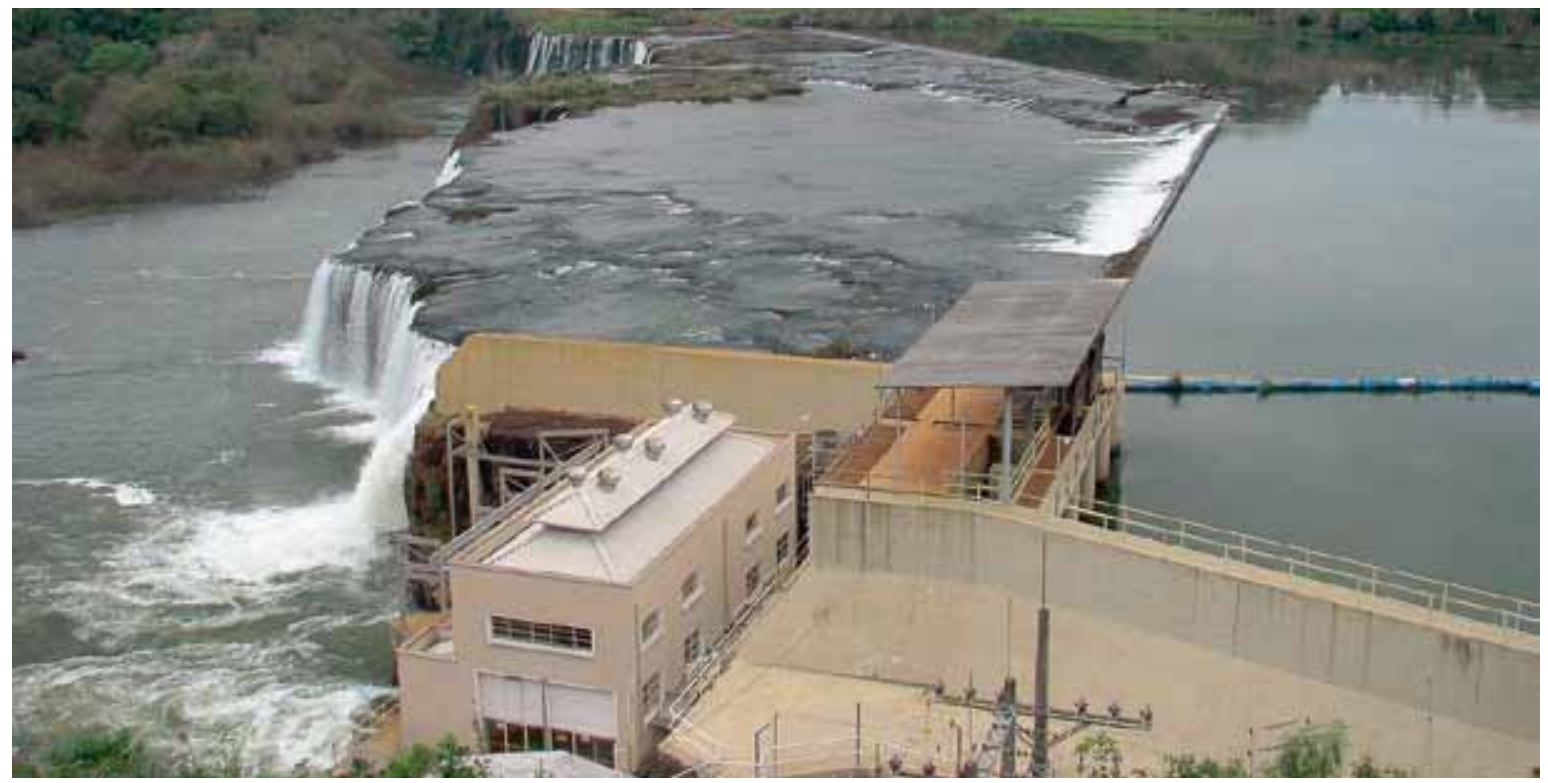

Usina Hidrelétrica Foz do Chopim

(foto cedida pela Copel). 
(a)

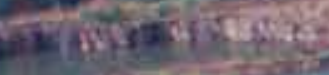

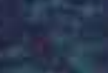

$\cos 25$

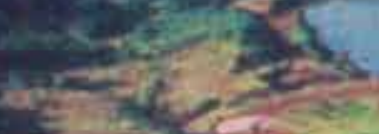

(1)

\section{$2 x+\infty$}

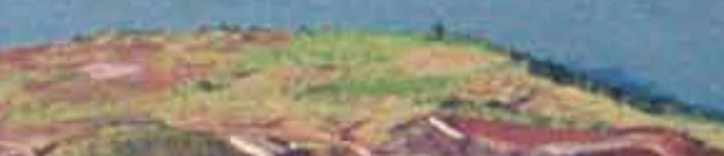
20.

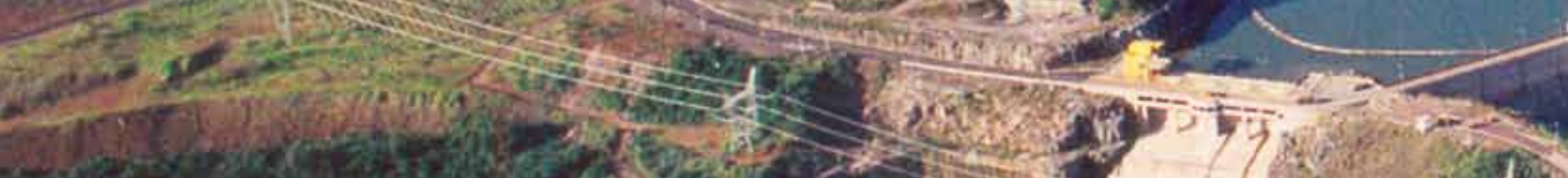
Nat

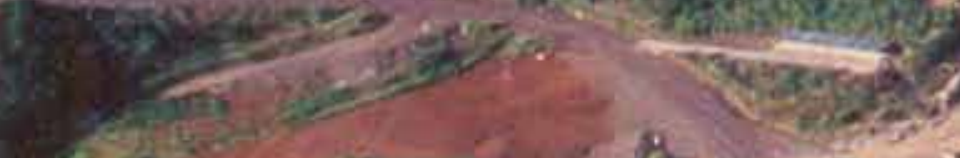

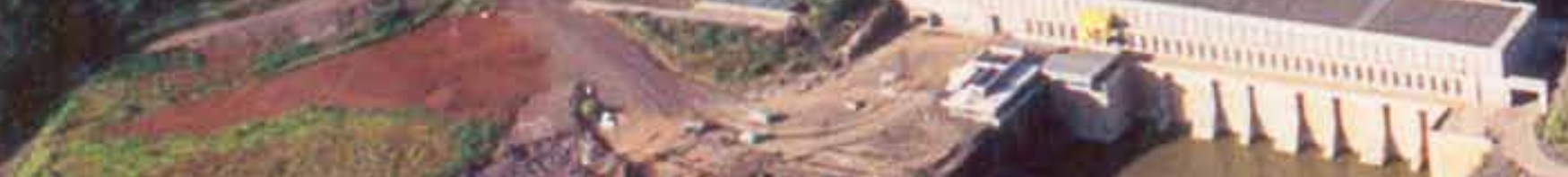

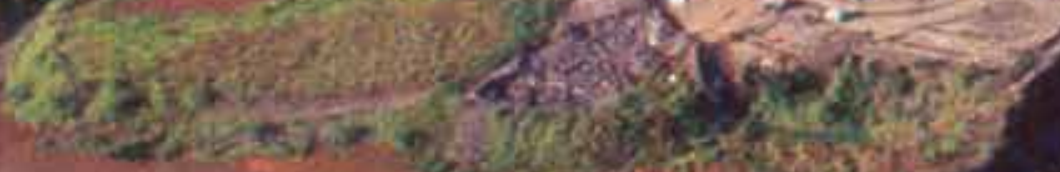

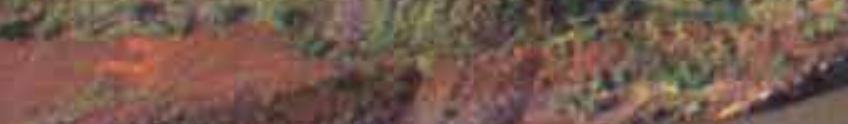

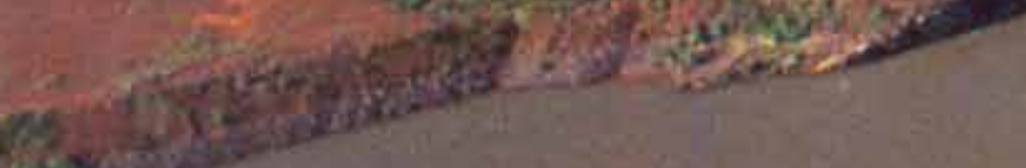

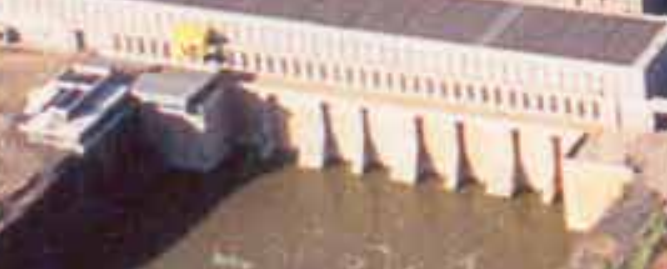




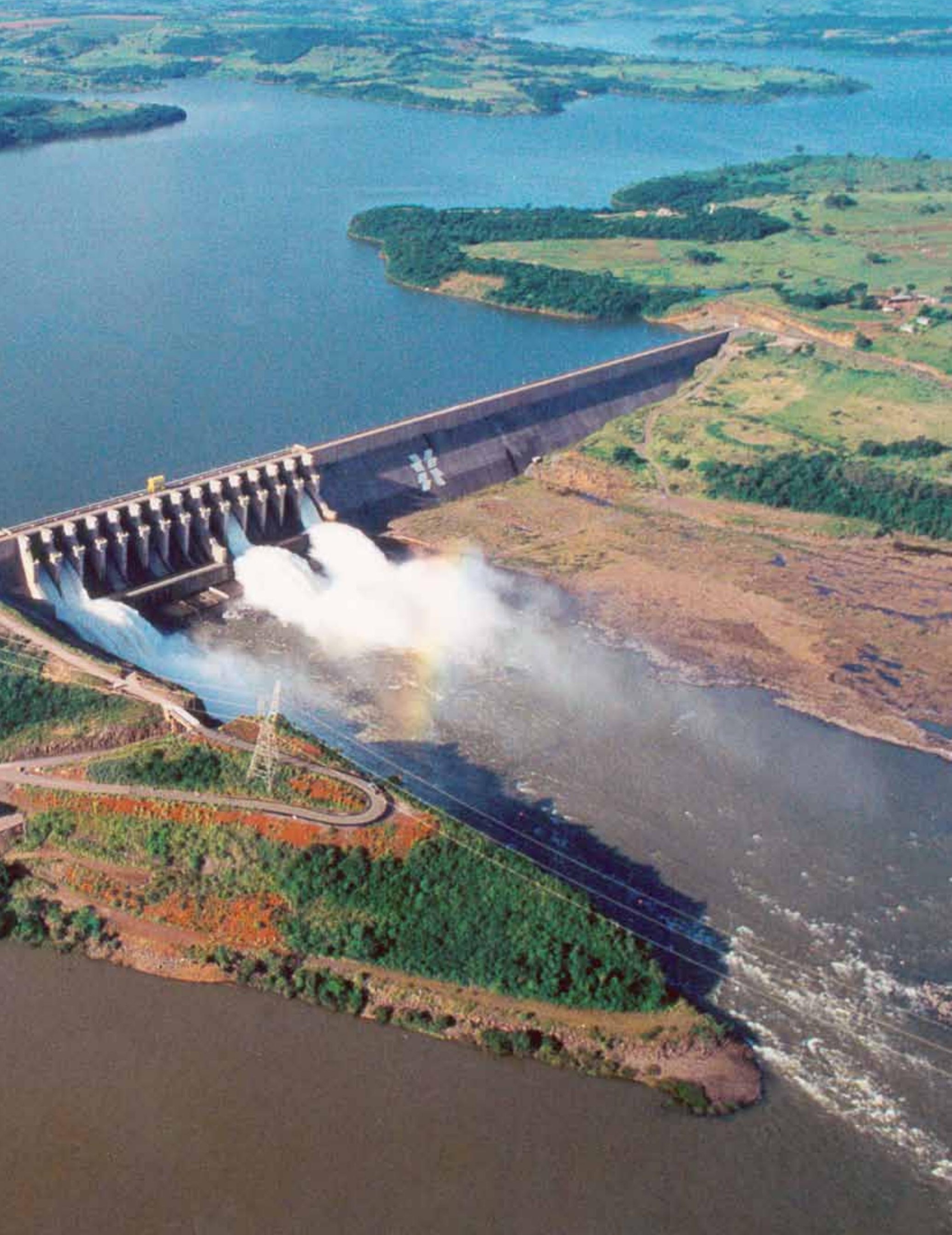




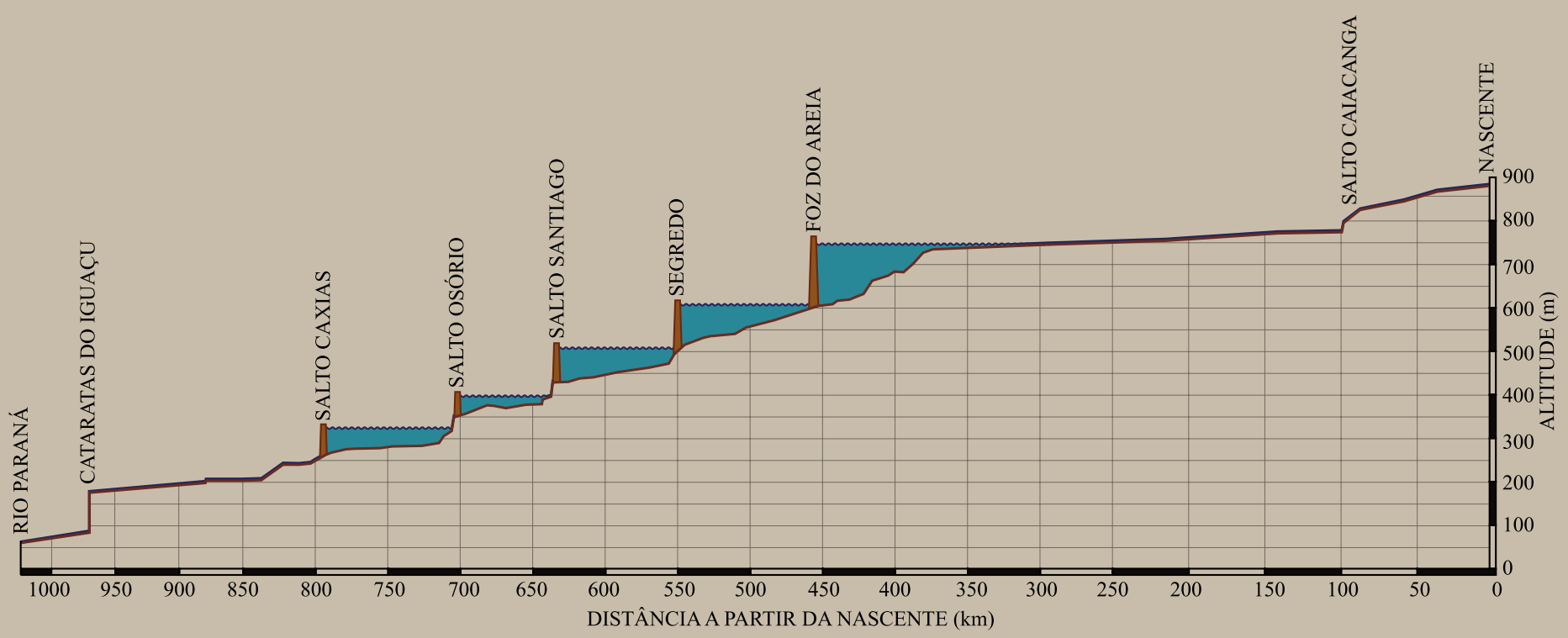

Perfil do rio Iguaçu e seus principais reservatórios, por Jaime Luiz Lopes Pereira (adaptado de Júlio Júnior, Bonecker e Agostinho, 1997). 
As espécies contempladas neste livro são aquelas que ocorrem na bacia do baixo rio Iguaçu, incluindo seus afluentes e reservatórios, assim como as espécies não indígenas. Os nomes populares apresentados foram baseados em Severi e Cordeiro (1994) e em informações dos ribeirinhos da região. Sempre que possível, são fornecidas fotos de exemplares recém coletados de cada espécie, os quais foram posteriormente destinados para fins diversos. Algumas espécies não nativas, cujos exemplares coletados na bacia do rio Iguaçu não estavam em bom estado para fotografar, tiveram exemplares fotografados de lotes de suas bacias de origem. Os exemplares fotografados de lotes catalogados e não catalogados estão relacionados nos anexos 1 e 3 .

Para a caracterização morfológica das espécies, foram utilizados os dados informados nas descrições originais e/ou em redescrições das espécies. No entanto, quando a espécie ainda não foi descrita ou se algum dado apresentado na descrição de uma congênere não é apresentado na da outra, foram tomadas medidas e contagens complementares, quando possível. Os lotes dos peixes medidos estão relacionados no anexo 2 e os das espécies não indígenas, que não estão relacionados em nenhum anexo anterior, estão listados no anexo 4. Os dados retirados de referências encontram-se assinalados no texto com um *, cuja fonte se encontra no final da descrição. As medidas são apresentadas na sua maioria como proporções do comprimento padrão (CP), com exceção das subunidades da cabeça, expressas como proporções do comprimento da cabeça (CC).

O padrão de colorido de cada espécie foi sucintamente descrito preferencialmente de indivíduos recém-fixados, mas muitas vezes, por indisponibilidade, foi obtido de indivíduos fixados há mais tempo, sempre considerando pinta menor do que mancha e listra mais estreita do que faixa. Alguns dados biológicos baseados em autores que trabaIharam com as espécies na bacia do Iguaçu são apresentados sempre 
que disponíveis. $O$ símbolo $\mathrm{L}_{50}$ corresponde ao comprimento padrão em que $50 \%$ dos indivíduos estão aptos a se reproduzir. Comentários acerca do status taxonômico de algumas espécies e outras informações relevantes são igualmente fornecidos.

Informações adicionais das espécies referem-se ao endemismo na bacia do rio Iguaçu:

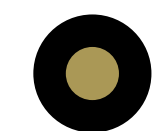

indígena endêmica

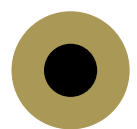

indígena nativa

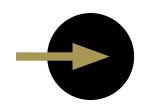

não indígena

À ocorrência da espécie na bacia do baixo rio Iguaçu:

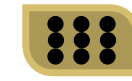

facilmente encontrada

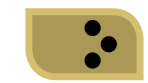

restrita a poucas localidades

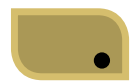

raramente encontrada

E ao porte, em relação às espécies da bacia do rio Iguaçu: pequeno, comprimento padrão menor do que 200 mm; médio, entre 200 e 400 $\mathrm{mm}$ e grande, maior do que $400 \mathrm{~mm}$.

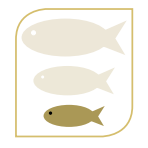

pequeno

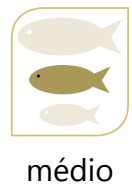

médio

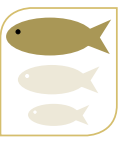

grande

Convém salientar que espécies não indígenas foram incluídas neste manual para permitir a sua identificação pelos leitores. Entretanto, tendo em vista uma série de imprevisibilidades quando da transposição de espécies entre bacias e/ou continentes, que incluem a competição com espécies nativas, podendo causar até extinções locais, alteração do habitat, introdução de doenças e parasitos, hibridização, além da incerteza sobre o seu sucesso, entre outros, acreditamos que esta prática deve ser sempre desencorajada, a fim de manter a biodiversidade natural o mais íntegra possível, para que possa ser conhecida, estudada e conservada para as gerações futuras.

Abreviaturas institucionais utilizadas são: Copel, Companhia Paranaense de Energia; Gerpel, Grupo de Pesquisas em Recursos Pesqueiros e Limnologia; MCP, Museu de Ciências e Tecnologia da Pontifícia Universidade Católica do Rio Grande do Sul; MHNCI, Museu de História Natural do Capão de Imbuia; MZUSP, Museu de Zoologia da Universidade de São Paulo; NUP, Coleção Ictiológica do Nupélia; Nupélia, 
Núcleo de Pesquisas em Limnologia, Ictiologia e Aquicultura; UEM, Universidade Estadual de Maringá; Unioeste, Universidade Estadual do Oeste do Paraná.

\section{DESCRIÇÃO DOS DADOS MORFOMERÍSTICOS}

\section{Medidas}

As medidas foram tomadas, sempre que possível, do lado esquerdo do peixe. A seguir é apresentada a descrição de cada medida, assim como algumas abreviaturas utilizadas ao longo do texto.

- Altura da cabeça - distância medida transversalmente na região mais alta da cabeça;

- Altura do corpo - distância medida transversalmente na região mais alta do corpo, exceto para Loricariidae, onde foi medida a partir do osso occiptal;

- Altura do pedúnculo caudal - distância medida transversalmente na parte mais baixa do pedúnculo caudal;

- Comprimento da base da nadadeira adiposa - distância entre as inserções anterior e posterior da nadadeira adiposa;

- Comprimento da base da nadadeira anal - distância entre as inserções do primeiro e último raios da nadadeira anal;

- Comprimento da cabeça (CC) - distância entre as extremidades anterior do focinho e súpero-posterior do opérculo, excluindo a membrana opercular, exceto para os Loricariidae, onde foi medida a distância da extremidade superior do focinho à extremidade do osso occiptal;

- Comprimento da cauda - distância da origem do último raio da nadadeira anal até a extremidade da cauda (Gymnotidae), ou da nadadeira caudal em Apteronotidae;

- Comprimento da nadadeira peitoral - distância medida da origem da nadadeira peitoral até a extremidade do seu raio mais longo (Gymnotidae);

- Comprimento do barbilhão maxilar - distância da base do barbiIhão maxilar até a sua extremidade distal;

- Comprimento do barbilhão nasal - distância da base do barbilhão nasal (narina) até a sua extremidade distal (Trichomycteridae);

- Comprimento do barbilhão rictal - distância da base do barbilhão rictal (queixo) até a sua extremidade distal (Trichomycteridae);

- Comprimento do acúleo da nadadeira dorsal - distância da origem do acúleo da nadadeira dorsal até sua extremidade distal (Callichthyidae);

- Comprimento do acúleo da nadadeira peitoral - distância da origem do acúleo da peitoral até sua extremidade distal (Loricariidae); 
- Comprimento do focinho até a nadadeira anal (CFA) - distância entre a extremidade anterior do focinho e a origem do último raio da nadadeira anal;

- Comprimento do gonopódio - distância da origem do gonopódio até sua extremidade distal;

- Comprimento do pedúnculo caudal - distância entre a origem do último raio da nadadeira anal e a extremidade posterior da coluna vertebral, percebida ao se curvar a nadadeira caudal para os lados;

- Comprimento do primeiro raio da nadadeira dorsal - distância da origem do primeiro raio da nadadeira dorsal até sua extremidade distal (Loricariidae);

- Comprimento padrão (CP) - distância entre a extremidade anterior do focinho e a extremidade posterior da coluna vertebral, evidenciada ao se curvar a nadadeira caudal para os lados;

- Comprimento pré-nadadeiras - distância entre a extremidade anterior do focinho e a origem do primeiro raio das nadadeiras dorsal, anal, peitoral e pélvica;

- Comprimento total (CT) - distância entre a extremidade anterior do focinho e a extremidade posterior da cauda (Gymnotidae);

- Comprimento do focinho - distância entre a extremidade anterior do focinho e a borda anterior do olho, excluindo a membrana orbital;

- Distância interorbital - menor distância entre as órbitas;

- Diâmetro orbital - maior distância longitudinal entre as bordas anterior e posterior do olho;

- Largura da boca - medida horizontal da fenda bucal (Gymnotidae);

- Largura do dentário - comprimento da área que contém dentes na hemissérie esquerda do dentário (Ancistrus).

\section{Contagens}

- Cúspides dos dentes - número de cúspides dos dentes sinfisianos das séries interna e externa do pré-maxilar;

- Dentes do maxilar - número total de dentes do osso maxilar, sendo apresentado o maior número, caso diferente entre os dois lados;

- Dentes do pré-maxilar - número de dentes da hemissérie, sendo apresentado o maior número, caso haja diferenças entre os dois lados;

- Dentes do dentário - número de dentes da hemissérie do dentário, sendo apresentado o maior número, caso haja diferenças entre os dois lados; 
- Escamas da linha lateral - número de escamas perfuradas na linha lateral;

- Escamas da linha longitudinal - número de escamas do final do opérculo até a base da nadadeira caudal, da série que contém a linha lateral (Loricariidae), ou a do meio do corpo, quando a linha lateral é ausente (Atherinopsidae);

- Escamas da linha transversal abaixo da linha lateral - número de séries longitudinais de escamas abaixo da linha lateral, na vertical da origem da nadadeira pélvica;

- Escamas da linha transversal acima da linha lateral - número de séries longitudinais de escamas acima da linha lateral, na região mais alta do corpo, geralmente coincidindo com a origem da nadadeira dorsal;

- Escamas do ramo inferior da linha lateral - número de escamas perfuradas no ramo inferior da linha lateral (Cichlidae);

- Escamas do ramo superior da linha lateral - número de escamas perfuradas no ramo superior da linha lateral (Cichlidae);

- Placas da série lateral - número de placas da série que contém a linha lateral (Loricariidae);

- Placas da série lateral superior - número de placas da série lateral superior (Callichthyidae);

- Placas da série lateral inferior - número de placas da série lateral inferior (Callichthyidae);

- Placas pré-dorsais - número de placas após o processo supraoccipital até a origem da nadadeira dorsal;

- Placas na base da dorsal - número de placas na base dos raios da nadadeira dorsal (Loricariidae);

- Quilha ventral - número de escamas modificadas em espinhos simples, seguido pelo número de espinhos pares, contados da região anteroventral do corpo até a origem da nadadeira anal (Serrasalmidae);

- Raios da nadadeira caudal - número total de raios da nadadeira caudal, excetuando-se os procorrentes (Apteronotidae);

- Raios das nadadeiras - número total de raios das nadadeiras (dorsal, peitoral, pélvica e anal), com exceção de Characiformes, onde os raios são apresentados de maneira separada, considerando os raios indivisos e os ramificados;

- Raios indivisos - número de raios moles, não ramificados (Characiformes), anteriores ao espinho das nadadeiras (Cyprinus), representados por algarismos romanos minúsculos (i). 


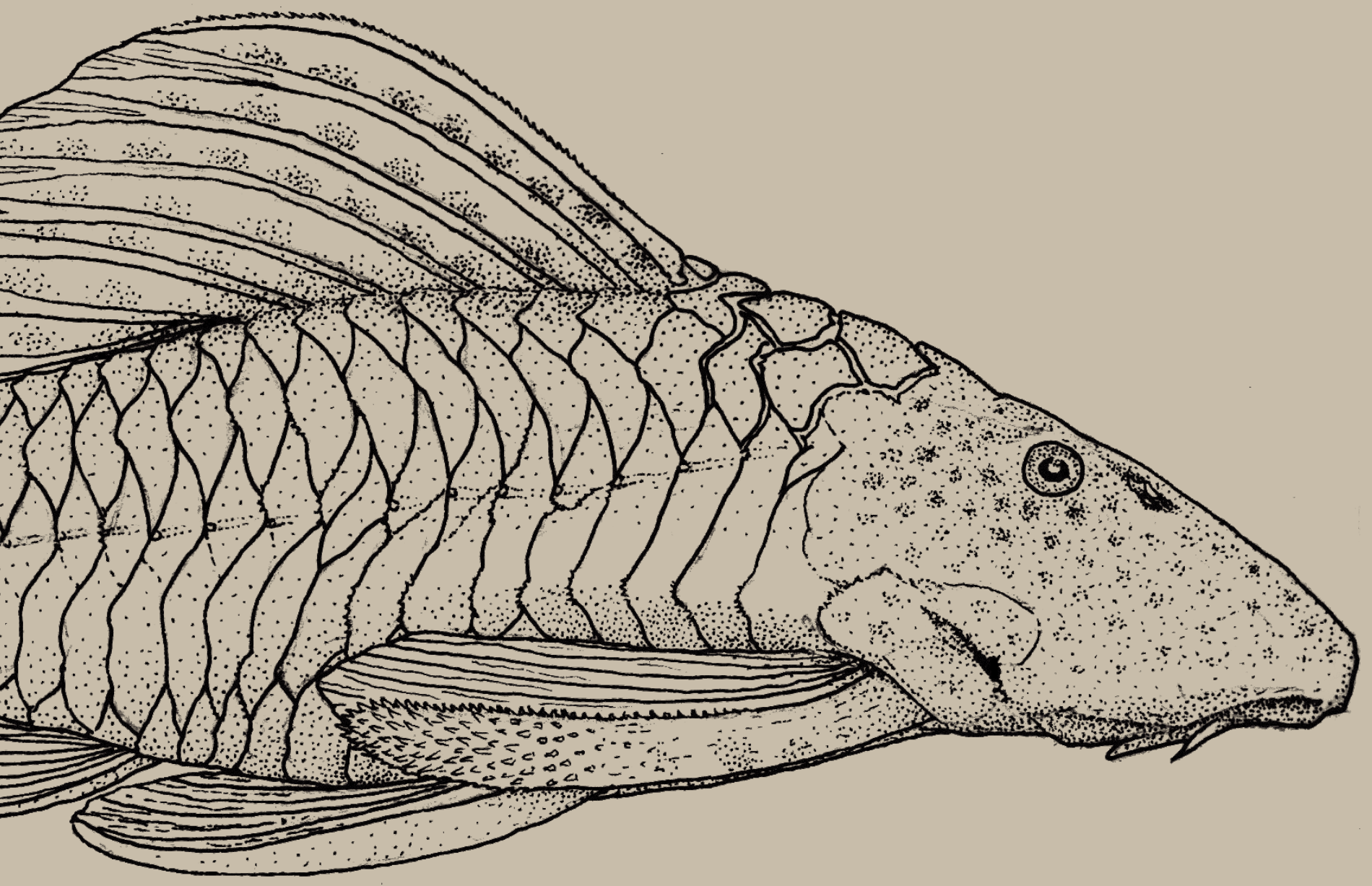




\section{CLASSIFICAÇÃO}

Classificação das espécies da bacia do baixo rio Iguaçu seguindo Nelson (2006) para ordens, Cyprinidae, Centrarchidae e famílias de Siluriformes, e Reis, Kullander e Ferraris (2003) para demais famílias, com exceção de Characidae e Serrasalmidae, que seguem Mirande (2009).

\section{CYPRINIFORMIES}

Cyprinidae

Ctenopharyngodon idella (Valenciennes, 1844)

Cyprinus carpio Linnaeus, 1758

Hypophthalmichthys molitrix (Valenciennes, 1844)

Hypophthalmichthys nobilis (Richardson, 1845)

\section{CHARACIFORMES}

Parodontidae

Apareiodon vittatus Garavello, 1977

Curimatidae

Cyphocharax cf. santacatarinae (Fernández-Yépez, 1948)

Steindachnerina brevipinna (Eigenmann \& Eigenmann, 1889)

Prochilodontidae

Prochilodus lineatus (Valenciennes, 1836)

Anostomidae

Leporinus aff. elongatus Valenciennes, 1850

Leporinus friderici (Bloch, 1794)

Leporinus macrocephalus Garavello \& Britski, 1988

Leporinus obtusidens (Valenciennes, 1837)

Leporinus octofasciatus Steindachner, 1915 
Crenuchidae

Characidium sp. 1

Characidium sp. 2

Serrasalmidae

Piaractus mesopotamicus (Holmberg, 1887)

Characidae

Astyanax altiparanae Garutti \& Britski, 2000

Astyanax bifasciatus Garavello \& Sampaio, 2010

Astyanax dissimilis Garavello \& Sampaio, 2010

Astyanax gymnodontus (Eigenmann, 1911)

Astyanax gymnogenys Eigenmann, 1911

Astyanax jordanensis Alcaraz, Pavanelli \& Bertaco, 2009

Astyanax longirhinus Garavello \& Sampaio, 2010

Astyanax minor Garavello \& Sampaio, 2010

Astyanax serratus Garavello \& Sampaio, 2010

Astyanax sp. 1

Astyanax sp. 2

Gênero indeterminado sp.

Hyphessobrycon reticulatus Ellis, 1911

Oligosarcus longirostris Menezes \& Géry, 1983

Salmininae

Salminus brasiliensis (Cuvier, 1816)

Bryconinae

Brycon hilarii (Valenciennes, 1850)

Stevardiinae

Bryconamericus ikaa Casciotta, Almirón \& Azpelicueta, 2004

Bryconamericus pyahu Azpelicueta, Casciotta \& Almirón, 2003

Bryconamericus sp.

Cyanocharax aff. alburnus (Hensel, 1870)

Mimagoniates microlepis (Steindachner, 1877)

Erythrinidae

Hoplias sp. 1

Hoplias sp. 2

\section{SILURIFORMES}

Trichomycteridae

Trichomycterus castroi de Pinna, 1992

Trichomycterus crassicaudatus Wosiacki \& de Pinna, 2008

Trichomycterus davisi (Haseman, 1911)

Trichomycterus igobi Wosiacki \& de Pinna, 2008

Trichomycterus mboycy Wosiacki \& Garavello, 2004

Trichomycterus papilliferus Wosiacki \& Garavello, 2004

Trichomycterus plumbeus Wosiacki \& Garavello, 2004 
Trichomycterus stawiarski (Miranda Ribeiro, 1968)

Trichomycterus taroba Wosiacki \& Garavello, 2004

Trichomycterus sp. 1

Trichomycterus sp. 2

Callichthyidae

Callichthys callichthys (Linnaeus, 1758)

Corydoras carlae Nijssen \& Isbrücker, 1983

Corydoras ehrhardti Steindachner, 1910

Corydoras aff. paleatus (Jenyns, 1842)

Hoplosternum littorale (Hancock, 1828)

Loricariidae

Neoplecostominae

Neoplecostomus sp.

Pareiorhaphis cf. parmula Pereira, 2005

Hypoptopomatinae

Hisonotus yasi (Almirón, Azpelicueta \& Casciotta, 2004)

Hisonotus sp.

Loricariinae

Loricariichthys cf. melanocheilus Reis \& Pereira, 2000

Loricariichthys cf. rostratus Reis \& Pereira, 2000

Rineloricaria maacki Ingenito, Ghazzi, Duboc \& Abilhoa, 2008

Hypostominae

Ancistrus abilhoai Bifi, Pavanelli \& Zawadzki, 2009

Ancistrus agostinhoi Bifi, Pavanelli \& Zawadzki, 2009

Ancistrus mullerae Bifi, Pavanelli \& Zawadzki, 2009

Ancistrus sp.

Hypostomus albopunctatus (Regan, 1908)

Hypostomus commersoni Valenciennes, 1836

Hypostomus derbyi (Haseman, 1911)

Hypostomus myersi (Gosline, 1947)

Heptapteridae

Heptapterus sp.

"Pariolius" hollandi (Haseman, 1911)

"Pariolius" sp.

Rhamdia branneri Haseman, 1911

Rhamdia voulezi Haseman, 1911

Rhamdia sp.

Ictaluridae

Ictalurus punctatus (Rafinesque, 1818)

Auchenipteridae

Glanidium ribeiroi Haseman, 1911

Tatia jaracatia Pavanelli \& Bifi, 2009

Clariidae

Clarias gariepinus (Burchell, 1822) 
Pimelodidae

Pimelodus britskii Garavello \& Shibatta, 2007

Pimelodus ortmanni Haseman, 1911

Pseudoplatystoma corruscans (Spix \& Agassiz, 1829)

Pseudoplatystoma reticulatum Eigenmann \& Eigenmann, 1889

Steindachneridion melanodermatum Garavello, 2005

\section{GYMNOTIFORMIES}

Gymnotidae

Gymnotus inaequilabiatus (Valenciennes, 1839)

Gymnotus sylvius Albert \& Fernandes-Matioli, 1999

Apteronotidae

Apteronotus ellisi (Arámburu, 1957)

Apteronotus sp.

\section{ATHERINIFORMIES}

Atherinopsidae

Odontesthes bonariensis (Valenciennes, 1835)

\section{CYPRINODONTIFORMIES}

Poeciliidae

Cnesterodon omorgmatos Lucinda \& Garavello, 2001

Phalloceros harpagos Lucinda, 2008

Anablepidae

Jenynsia diphyes Lucinda, Ghedotti \& Graça, 2006

Jenynsia eigenmanni (Haseman, 1911)

\section{SYNBRANCHIFORMES}

Synbranchidae

Synbranchus marmoratus Bloch, 1795

\section{PERCIFORMIES}

Centrarchidae

Micropterus salmoides (Lacépede, 1802)

Cichlidae

Australoheros angiru Říčan, Piálek, Almirón \& Casciotta, 2011

Australoheros kaaygua Casciotta, Almirón \& Gómez, 2006

Cichla kelberi Kullander \& Ferreira, 2006

Cichlasoma paranaense Kullander, 1983

Crenicichla iguassuensis Haseman, 1911

Crenicichla tesay Casciotta \& Almirón, 2008

Crenicichla yaha Casciotta, Almirón \& Gómez, 2006

Geophagus brasiliensis (Quoy \& Gaimard, 1824)

Oreochromis niloticus (Linnaeus, 1758)

Tilapia rendalli (Boulenger, 1897) 
Do total de 106 espécies incluídas neste manual, se considerarmos as muitas não-indígenas, que ocorreram esporadicamente, com exceção de Odontesthes bonariensis, 28,3\% delas corresponderiam a estas espécies, diminuindo a taxa de endemismo da ictiofauna para $50 \%$. Entretanto, este valor deve ser calculado considerando apenas as espécies indígenas, mais O. bonariensis, única não indígena já estabelecida na bacia. Desta maneira, o porcentual de endemismo ictiofaunístico do Iguaçu é de $69,7 \%$, contra $30,3 \%$ de indígenas não endêmicas, mais $O$. bonariensis, que corresponde a $0,9 \%$ do total de espécies relacionadas neste manual. Este valor corresponde ao informado por Abell, Thieme, Revenga, Bryer, Kottelat, Bogutskaya, Coad, Mandrak, Contreras Balderas, Bussing, Stiassny, Skelton, Allen, Unmack, Naseka, Rebecca, Sindorf, Robertson, Armijo, Higgins, Heibel, Wikramanayake, Olson, López, Reis, Lundberg, Sabaj-Pérez e Petry (2008), que classificaram a bacia do Iguaçu acima das Cataratas como contendo entre 51 e $71 \%$ de espécies endêmicas e por isso a consideraram uma ecorregião separada do restante da bacia do rio Paraná.

Em um catálogo sobre as espécies de peixes de água doce do Brasil, Buckup, Menezes e Ghazzi (2007) listaram apenas 22 das espécies indígenas listadas aqui como ocorrentes na bacia do rio Iguaçu. Como aquele catálogo foi elaborado por diferentes autores para cada capítulo correspondente às famílias de peixes, das 52 espécies não listadas por eles, algumas foram descritas depois, outras não foram citadas, mas também muitos autores não consideram a bacia do Iguaçu separadamente da bacia do rio Paraná.

Garavello, Pavanelli e Suzuki (1999) realizaram um levantamento das espécies capturadas pelo Nupélia em três anos de monitoramento após a formação do reservatório de Segredo, onde listaram 52 espécies de peixes acima das Cataratas do Iguaçu. Destas, Astyanax sp. F e Psalidodon sp. foram consideradas como uma única espécie, Astyanax gymnodontus, por Pavanelli e Oliveira (2009). Sendo assim, ao se comparar a lista de espécies apresentada aqui com aquela (op. cit.), percebe-se um incremento de 50 espécies, ou seja, mais de $100 \%$. Algumas identificações foram alteradas ao longo dos anos, várias espécies chamadas de sp. na lista de Segredo, hoje, já possuem nomes formais, mas cerca de metade das espécies que foram acrescentadas aqui correspondem a não indígenas. A despeito de todas elas estarem sendo capturadas esporadicamente na bacia, provenientes principalmente de escapes de pisciculturas, este dado é alarmante e merece ser considerado em elaborações de estratégias conservacionistas para a bacia do baixo rio Iguaçu. O equilíbrio natural entre as espécies indígenas já tem sido completamente modificado pelas alterações de habitats causados pela construção das hidrelétricas, e a presença de espécies não indígenas deve ser evitada a qualquer preço, sob pena de ser mais um fator de grande risco para uma ictiofauna endêmica e, ainda atualmente, pouco estudada sob diferentes pontos de vista. 


\section{Chave para gêneros do baixo rio Iguaçu, com categorias superiores}
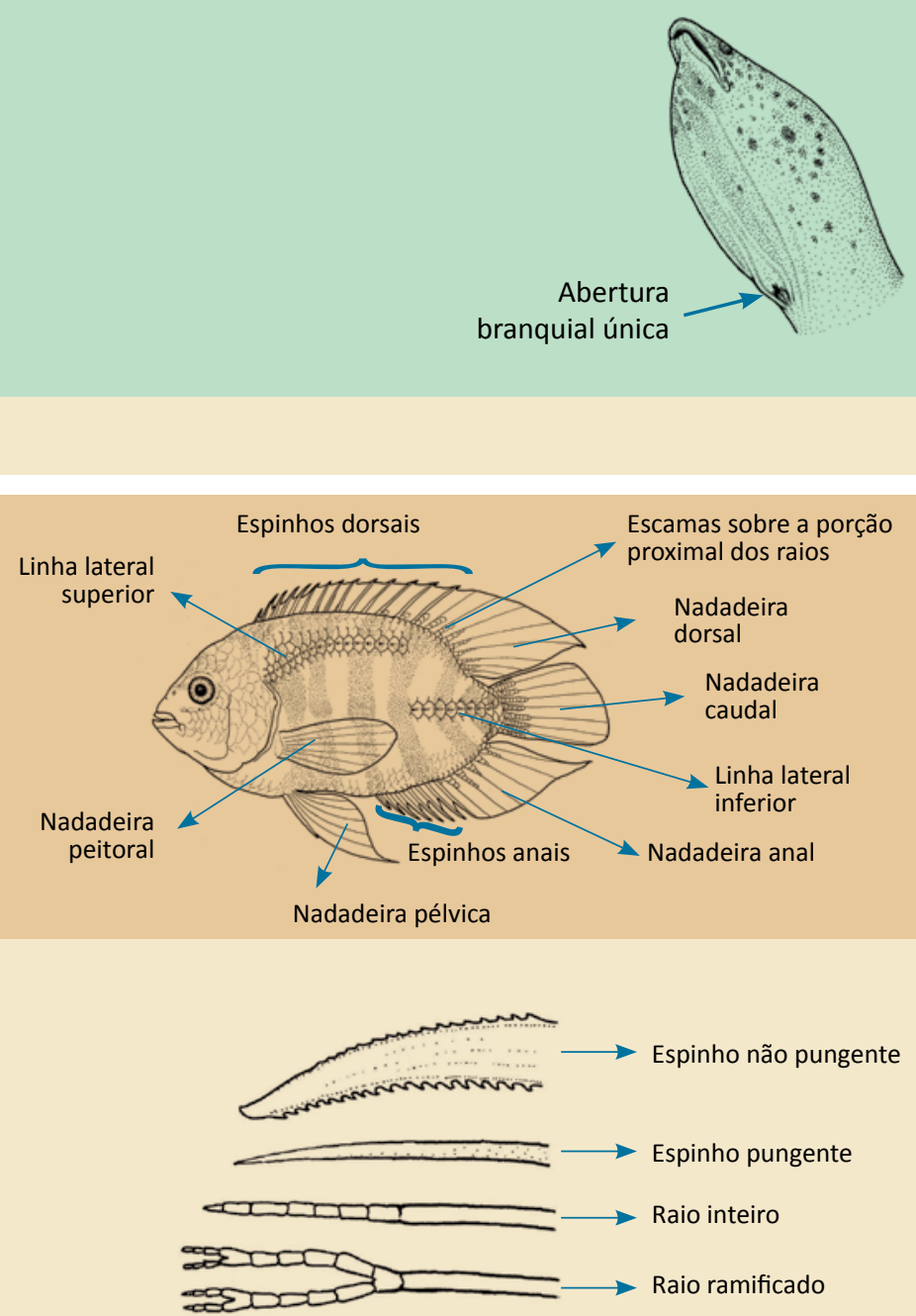
1. Uma única abertura branquial pequena, situada atrás da cabeça, na região mediano-ventral; corpo serpentiforme (SYNBRANCHIFORMES) Synbranchus (Synbranchidae)

1'. Um par de aberturas branquiais; corpo não serpentiforme 2

2. Raios anteriores da nadadeira dorsal e da anal transformados em espinhos pungentes (PERCIFORMES) 3

2'. Nadadeiras dorsal, anal e pélvica, quando presentes, sem espinhos (ou apenas com um dos raios transformado em acúleo, ou parcialmente intumescido, mas não pungente) 

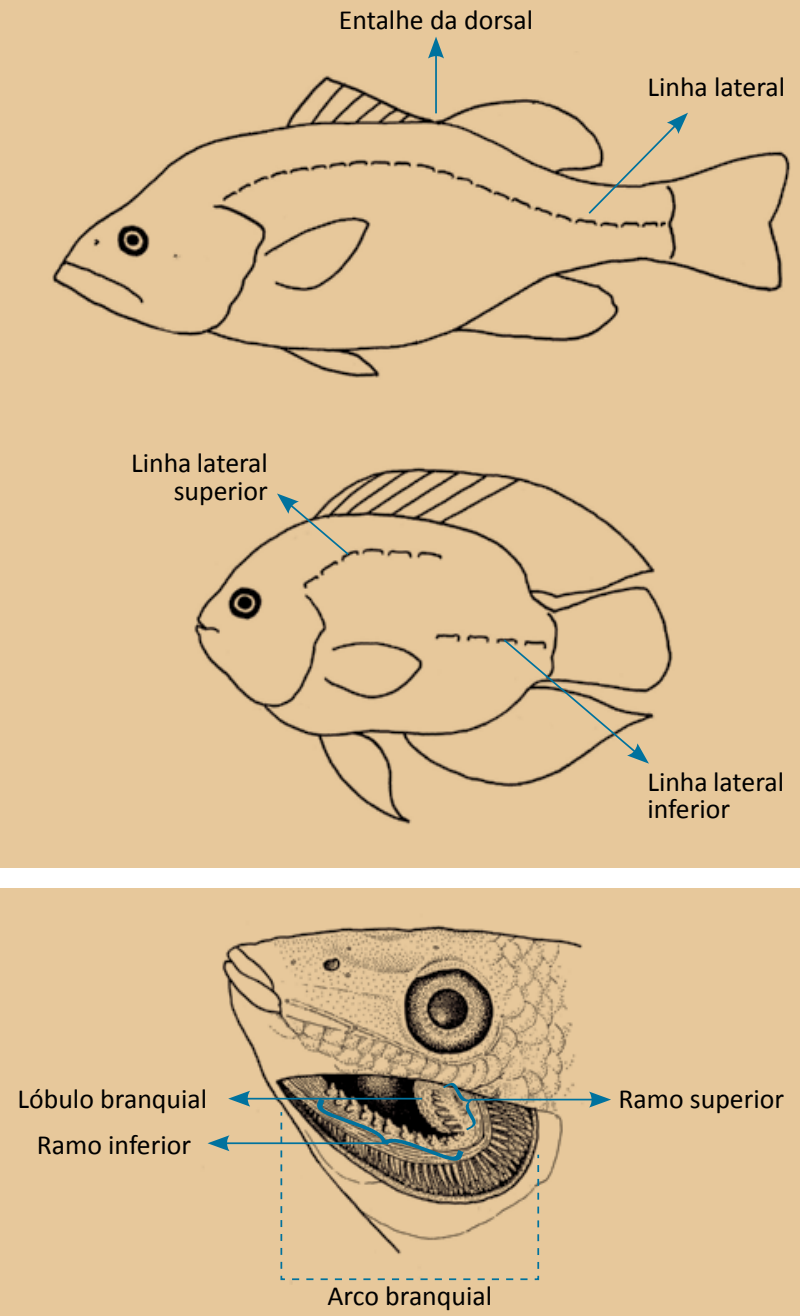
3. Linha lateral ondulada, mas contínua Micropterus (Centrarchidae)

p. 171

3'. Linha lateral interrompida, com um ramo superior e outro inferior

4. Com lóbulo desenvolvido no ramo superior do primeiro arco branquial Geophagus (Cichlidae)

p. 179

4'. Sem lóbulo no primeiro arco branquial 5

5. Escamas pequenas, mais de 65 na linha lateral superior; nadadeira dorsal com entalhe entre a parte de espinhos e a de raios flexíveis Cichla (Cichlidae)

p. 174

5'. Escamas grandes, menos de 30 na linha lateral superior; nadadeira dorsal com margem reta, sem entalhe entre as regiões anterior e posterior 


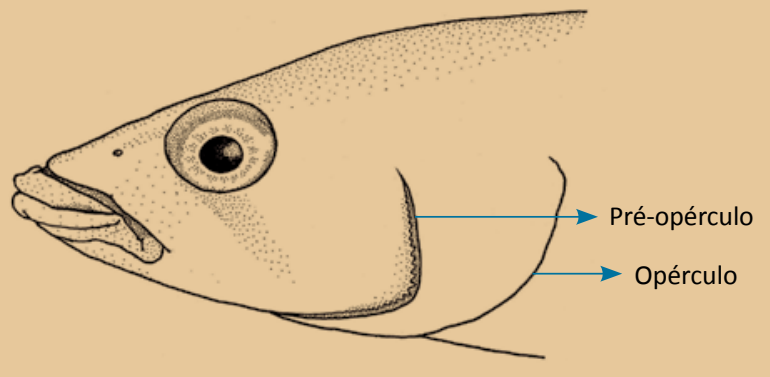


6. Borda posterior do pré-opérculo serrilhada; corpo alongado, sua altura contida 3,5 a 6 vezes no comprimento padrão

Crenicichla (Cichlidae)

p. 176

6'. Borda posterior do pré-opérculo lisa; corpo alto, sua altura contida de 2 a 3 vezes no comprimento padrão

7. Nadadeiras dorsal e anal recobertas por pequenas

escamas sobre a porção proximal dos raios

7'. Nadadeiras dorsal e anal sem escamas; 9

8. Nadadeira anal com mais de 5 raios anteriores transformados em espinho pungente Australoheros (Cichlidae)

8'. Nadadeira anal com no máximo 3 raios anteriores transformados em espinho pungente

9. Nadadeira caudal com várias faixas transversais alternando entre claras e escuras; mais de 20 rastros longos e finos no ramo inferior do primeiro arco branquial Oreochromis (Cichlidae)

p. 180

9'. Nadadeira caudal sem faixas definidas; menos de 15 rastros curtos e grossos no ramo inferior do primeiro arco branquial

Tilapia (Cichlidae)

p. 181 

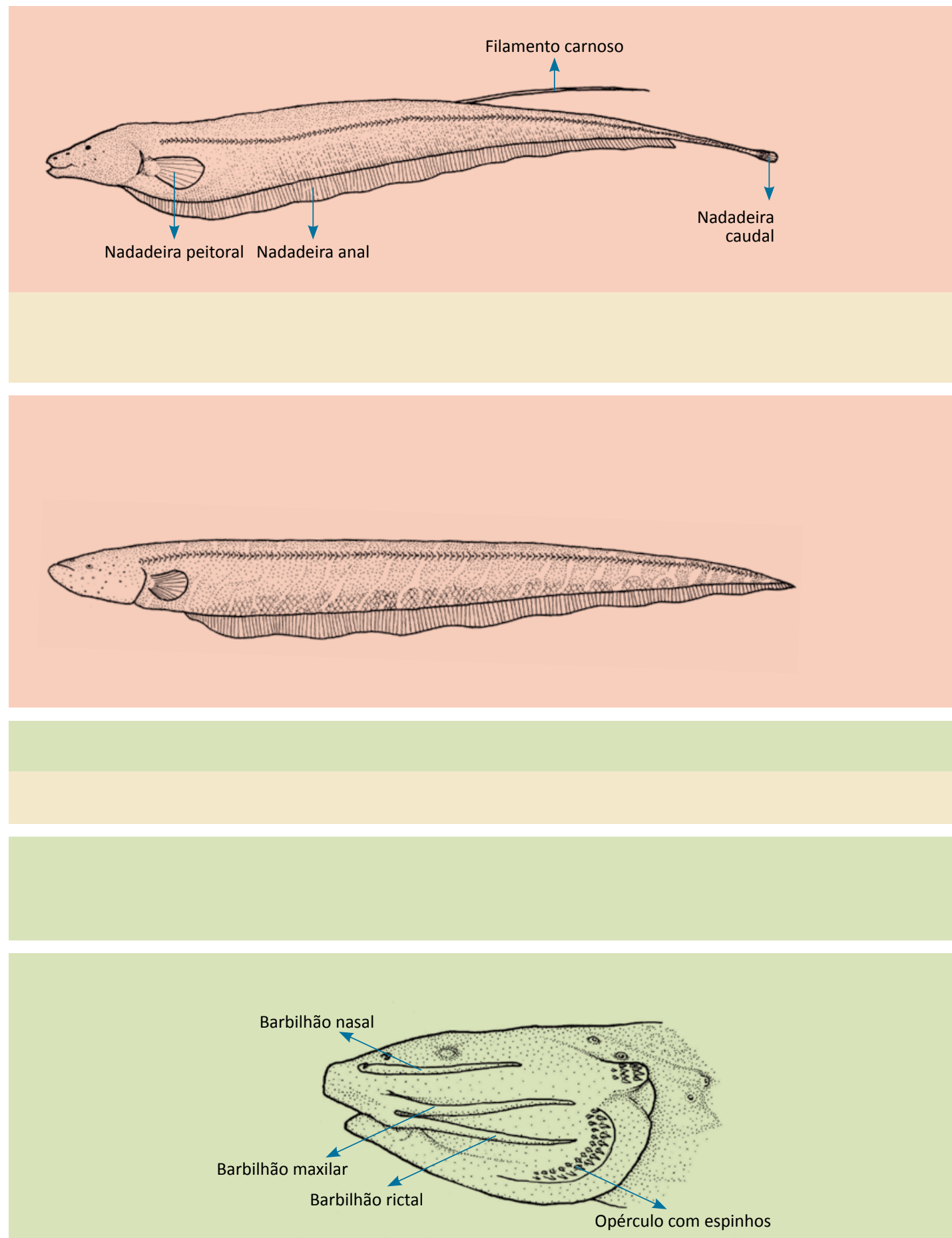
10. Corpo alongado, em forma de faca; nadadeira anal com mais de 100 raios; nadadeiras dorsal e pélvica ausentes (GYMNOTIFORMES)

10'. Corpo nunca em forma de faca; nadadeira anal com menos de 65 raios; nadadeiras dorsal e pélvica presentes

11. Nadadeira caudal presente; boca terminal Apteronotus (Apteronotidae)

p. 151

11'. Nadadeira caudal ausente; boca prognata Gymnotus (Gymnotidae)

12. Corpo nu ou coberto por placas dérmicas (SILURIFORMES) 13

12'. Corpo coberto por escamas 33

13. Corpo totalmente nu, sem placas ósseas 14

13'. Corpo coberto por placas ósseas 24

14. Barbilhões nasais presentes 15

14'. Barbilhões nasais ausentes 17

15. Opérculo com espinhos Trichomycterus (Trichomycteridae) 


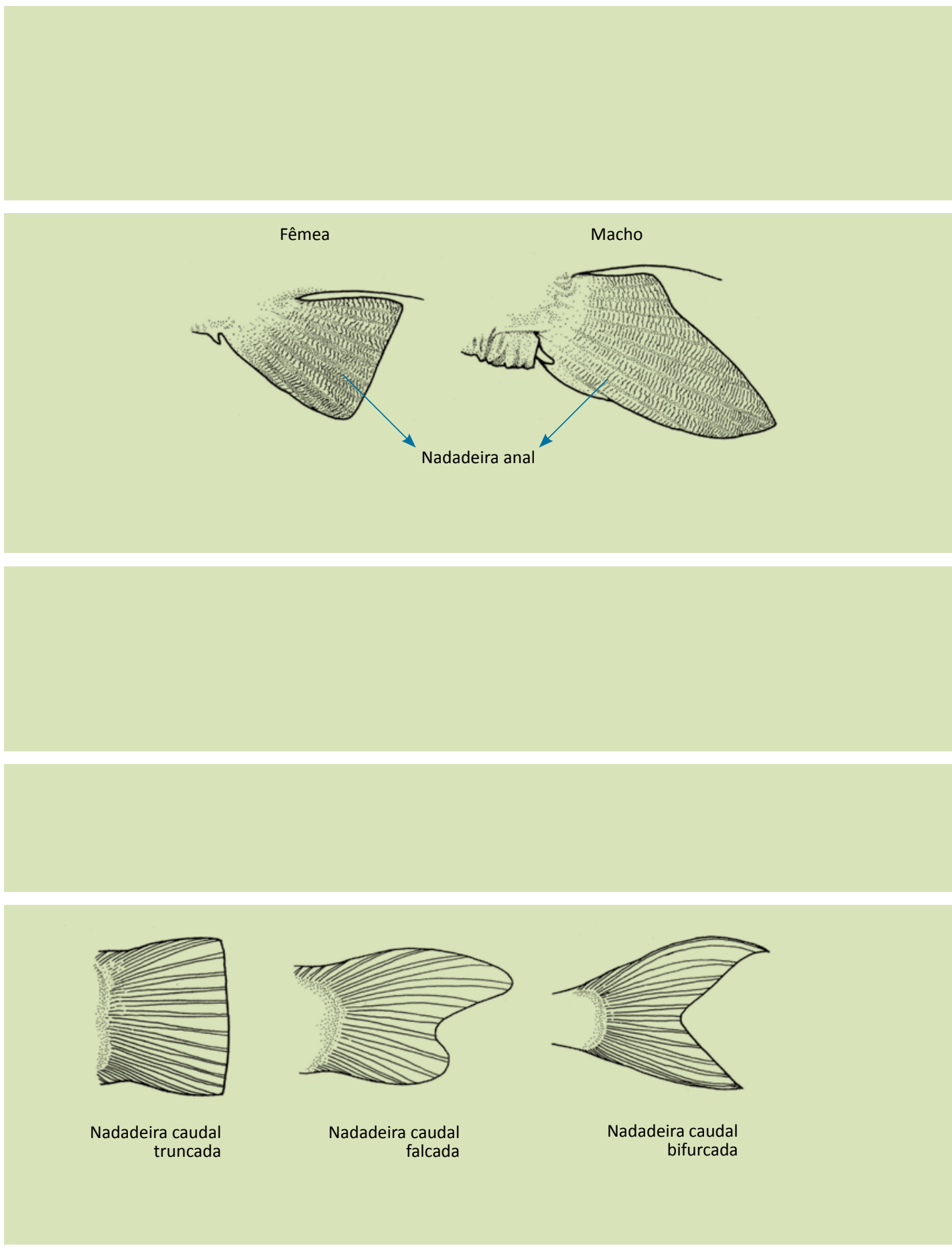


16. Nadadeira anal curta, com menos de 28 raios Ictalurus (Ictaluridae)

16'. Nadadeira anal longa, com mais de 45 raios Clarias (Clariidae)

p. 140

17. Nadadeira adiposa curta, sua base bem menor do que a base da nadadeira anal; machos adultos com dimorfismo sexual na nadadeira anal 18

17'. Nadadeira adiposa longa, sua base bem maior do que a base da nadadeira anal; machos não dimórficos

18. Corpo com coloração de fundo escura, com manchas claras Tatia (Auchenipteridae)

p. 139

18'. Corpo com coloração de fundo clara, com manchas escuras _ Glanidium (Auchenipteridae) p. 138

19. Primeiro raio da nadadeira dorsal não pungente, arredondado 20

19'. Primeiro raio da nadadeira dorsal pungente, perfurante 23

20. Altura do corpo contida mais de 6,5 vezes no comprimento padrão; nadadeira caudal falcada, de borda oblíqua

20'. Altura do corpo contida menos de 5,5 vezes no comprimento padrão; nadadeira caudal bifurcada

21. Nadadeira anal com 16 a 18 raios Heptapterus (Heptapteridae)

p. 132

21'. Nadadeira anal com 10 a 13 raios "Pariolius" (Heptapteridae) 

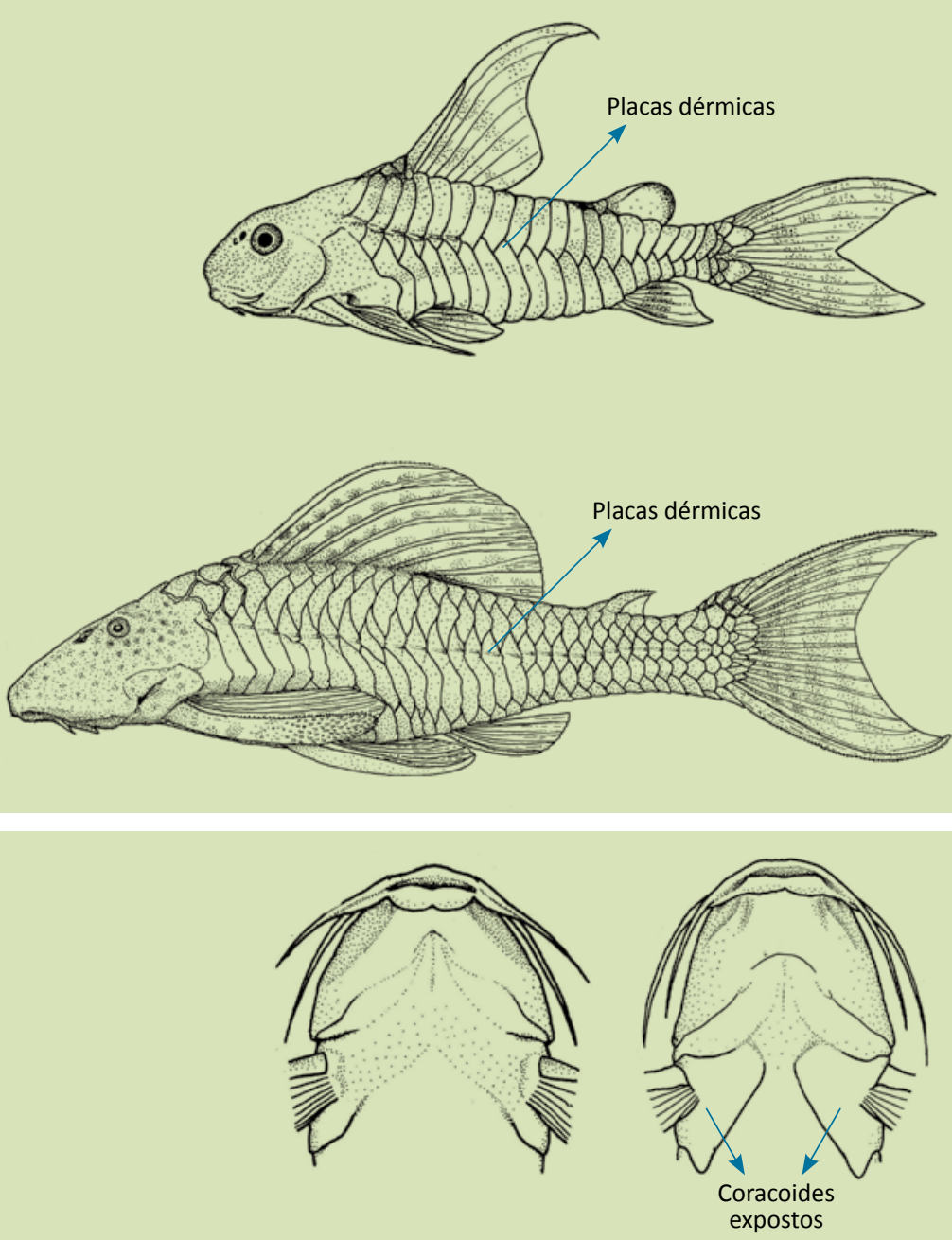

Vista ventral 
22. Nadadeira adiposa longa, sua base contida menos de 3,5 vezes no comprimento padrão Rhamdia (Heptapteridae)

p. 134

22'. Nadadeira adiposa curta, sua base contida mais de 4,5 vezes no comprimento padrão

23. Cabeça não deprimida; olho grande, contido menos de sete vezes no comprimento da cabeça; porte médio Pimelodus (Pimelodidae)

23'. Cabeça muito deprimida; olho pequeno, contido mais de nove vezes no comprimento da cabeça; porte grande

Pseudoplatystoma (Pimelodidae)

24. Duas séries de placas dérmicas altas de cada lado do corpo; boca terminal ou subterminal, não em forma de ventosa 25

24'. Várias séries longitudinais de placas dérmicas de cada lado do corpo; boca inferior, em forma de ventosa

25. Ossos coracoides entre as nadadeiras peitorais cobertos por pele Callichthys (Callichthyidae) 
Pedúnculo caudal deprimido

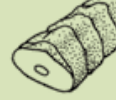

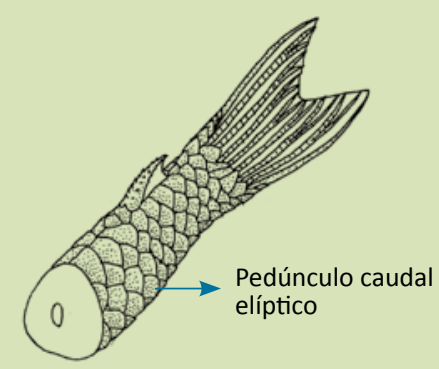
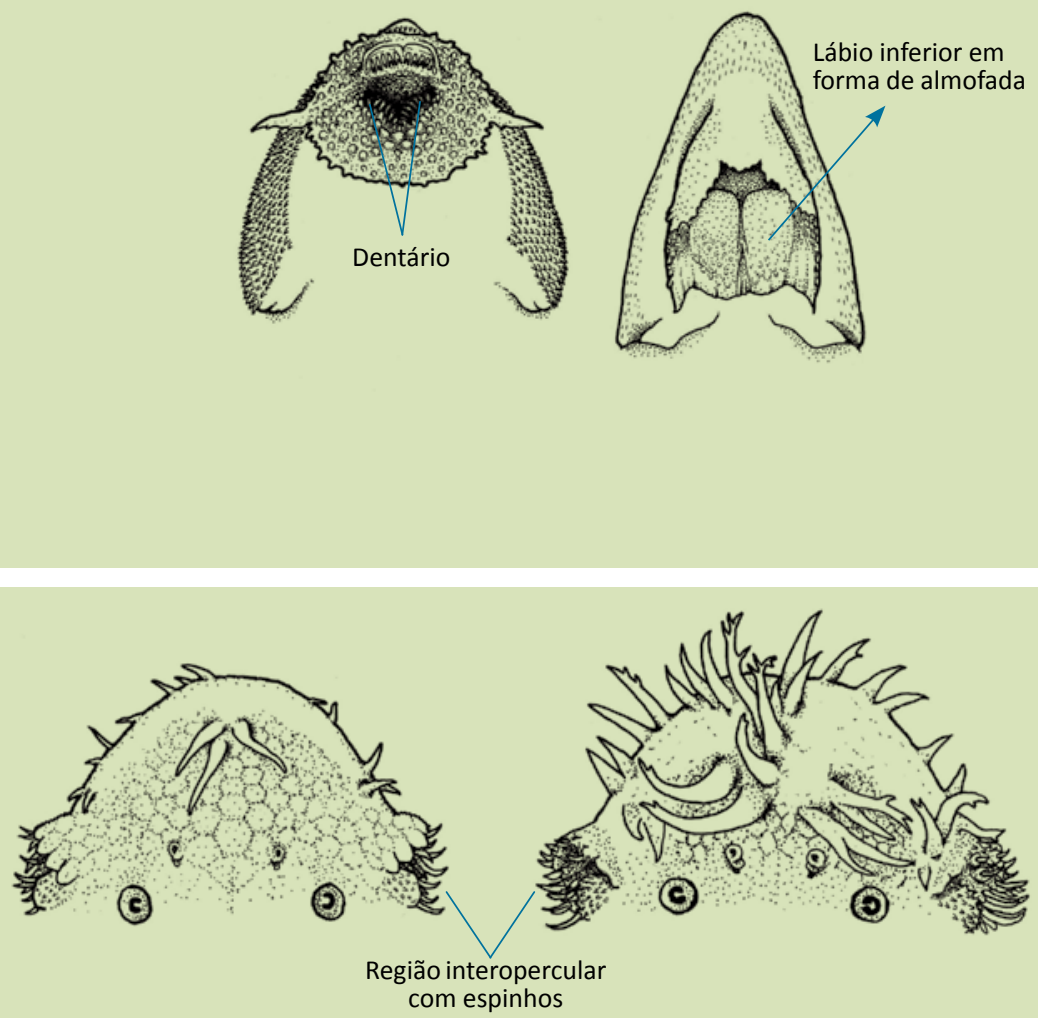
26. Cabeça mais alta do que larga; barbilhões maxilares curtos, não alcançando a abertura branquial Corydoras (Callichthyidae)

26'. Cabeça mais baixa do que larga; barbilhões maxilares longos, ultrapassando a abertura branquial

27. Pedúnculo caudal deprimido, sua altura contida mais de 40 vezes no comprimento padrão; nadadeira adiposa ausente

27'. Pedúnculo caudal elíptico ou arredondado em corte transversal, sua altura contida menos de 20 vezes no comprimento padrão; nadadeira adiposa presente (exceto em Hisonotus)

28. Lábio inferior espesso, em forma de duas almofadas; dentário com 10 a 15 dentes Loricariichthys (Loricariidae)

p. 122

28'. Lábio inferior não almofadado; dentário com 5 a 8 dentes Rineloricaria (Loricariidae)

29. Região interopercular móvel, provida de espinhos longos, fortes e protráteis Ancistrus (Loricariidae) 

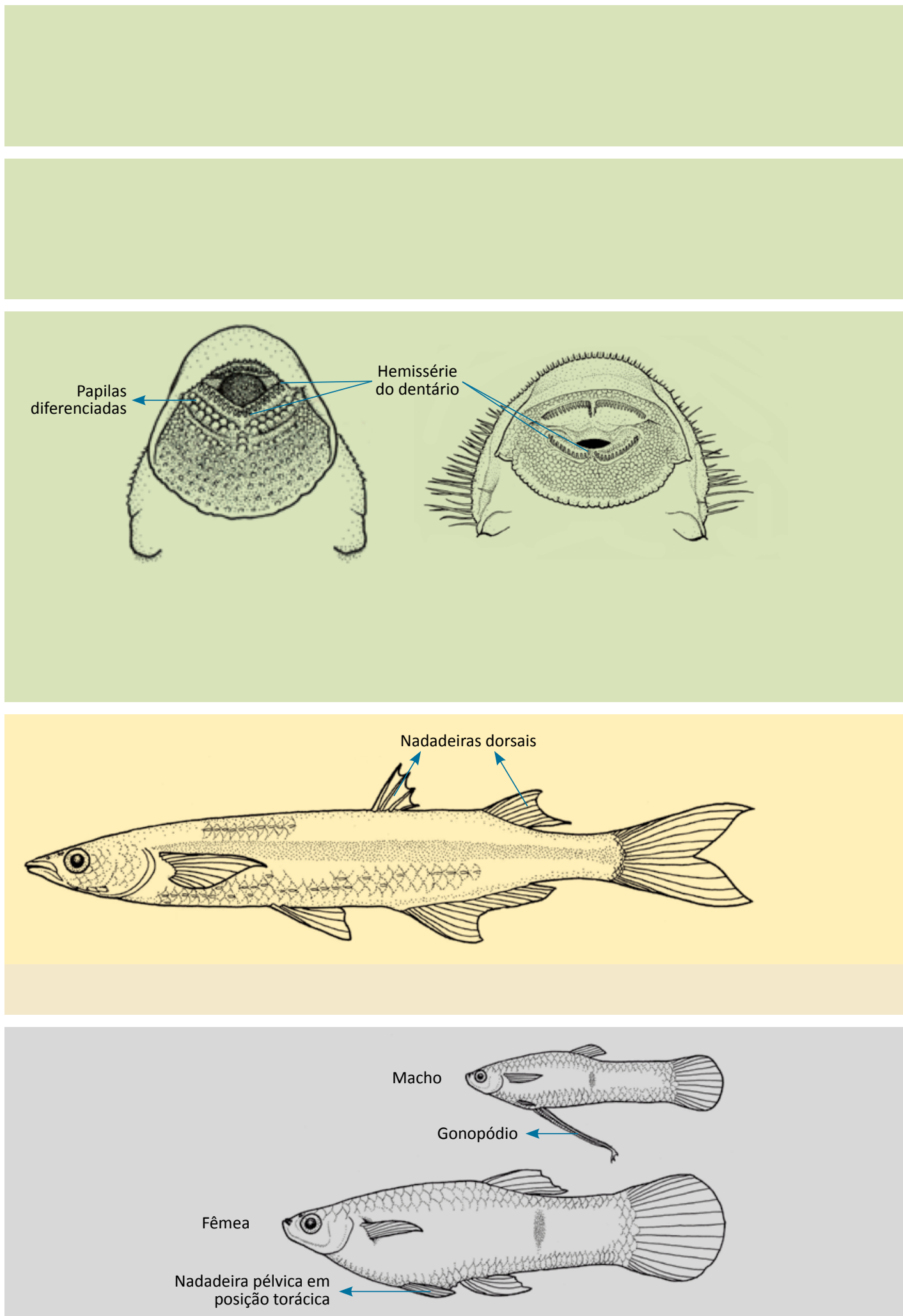
30. Nadadeira adiposa ausente Hisonotus (Loricariidae)

30'. Nadadeira adiposa presente 31

31. Nadadeira anal com cinco raios; porte médio a grande Hypostomus (Loricariidae) p. 128

31'. Nadadeira anal com seis raios; porte pequeno 32

32. Lábio inferior com uma fileira de papilas maiores que as demais, logo atrás dos dentes do dentário; machos sem odontódeos muito desenvolvidos Neoplecostomus (Loricariidae)

p. 118

32'. Lábio inferior sem fileira diferenciada de papilas, sendo todas similares no tamanho; machos adultos com odontódeos muito desenvolvidos na borda do focinho Pareiorhaphis (Loricariidae)

33. Duas nadadeiras dorsais, a primeira com raios espinhosos, mas flexíveis, e a segunda com raios segmentados (ATHERINIFORMES) Odontesthes (Atherinopsidae)

34. Machos adultos com gonopódio; nadadeira pélvica em posição torácica, ou seja, situada sob a peitoral; boca superior (CYPRINODONTIFORMES)

34'. Machos sem gonopódio; nadadeira pélvica em posição abdominal, ou seja, situada atrás da peitoral; boca terminal ou subterminal 
35. Nadadeira dorsal inserida à frente da vertical que passa pela origem da nadadeira anal; corpo com uma faixa longitudinal marrom-escura, às vezes segmentada Jenynsia (Anablepidae)

35'. Nadadeira dorsal inserida atrás da vertical que passa pela

p. 161 origem da nadadeira anal; corpo sem faixa longitudinal

36. Lateral do corpo frequentemente com uma mancha vertical preta, sob a nadadeira dorsal Phalloceros (Poeciliidae)

36'. Lateral do corpo com seis a nove manchas pretas irregulares ao longo do flanco Cnesterodon (Poeciliidae)

37. Maxilas sem dentes 38

37'. Maxilas com dentes, pelo menos parcialmente (CHARACIFORMES, em parte) 42

38. Barbilhão maxilar presente (CYPRINIFORMES) Cyprinus (Cyprinidae)

38'. Barbilhão maxilar ausente 39

39. Mais de 80 escamas na linha lateral Hypophthalmichthys (Cyprinidae)

39'. Menos de 80 escamas na linha lateral 40

40. Nadadeira adiposa ausente Ctenopharyngodon (Cyprinidae)

40'. Nadadeira adiposa presente (CHARACIFORMES, em parte) 41

41. Pedúnculo caudal sem mancha; pequena mancha cinza escuro na nadadeira dorsal, às vezes pouco conspícua; corpo com faixa longitudinal preta e estreita, ao longo de todo o flanco Steindachnerina (Curimatidae)

41'. Pedúnculo caudal com uma mancha cinza-escura grande e conspícua; nadadeira dorsal sem mancha; corpo com faixa longitudinal cinza-escura, larga, mais evidente após a vertical da região de inserção da nadadeira dorsal Cyphocharax (Curimatidae) 

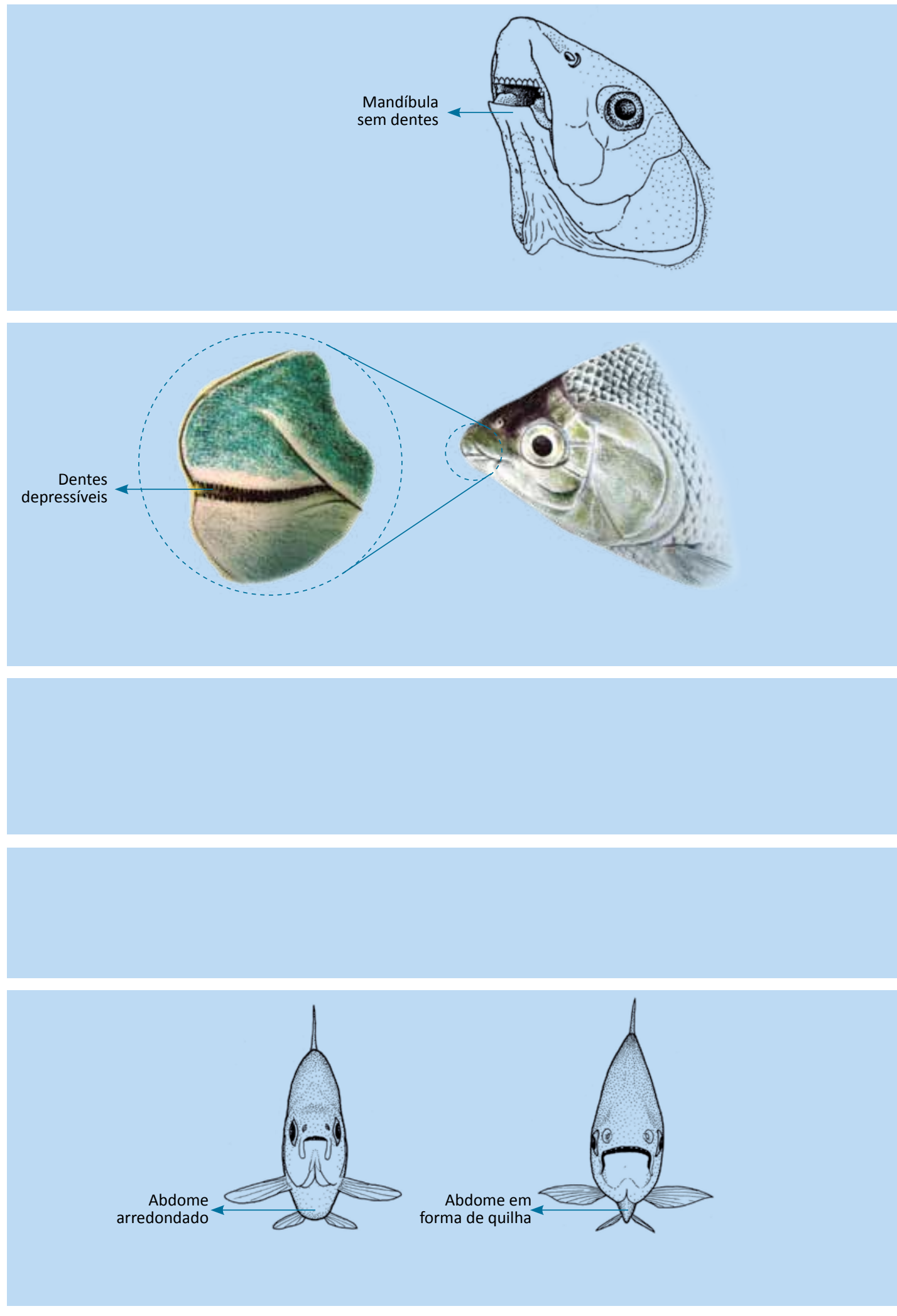
42. Mandíbula sem dentes Apareiodon (Parodontidae)

p. 59

42'. Mandíbula com dentes

43. Dentes depressíveis, pequenos e numerosos, implantados nos lábios

Prochilodus (Prochilodontidae)

43'. Dentes bem desenvolvidos, não depressíveis, implantados nos ossos das maxilas

44. Três, raramente dois, raios não ramificados na nadadeira peitoral Characidium (Crenuchidae)

44'. Um raio não ramificado na nadadeira peitoral 45

45. Nadadeira adiposa ausente Hoplias (Erythrinidae)

45'. Nadadeira adiposa presente p. 98 46

46. Abdome comprimido, em forma de quilha; linha lateral com mais de 100 escamas Piaractus (Serrasalmidae)

46'. Abdome arredondado; linha lateral com menos de 100 escamas 47

47. Uma série de dentes no pré-maxilar 48

47'. Duas ou três séries de dentes no pré-maxilar 49 


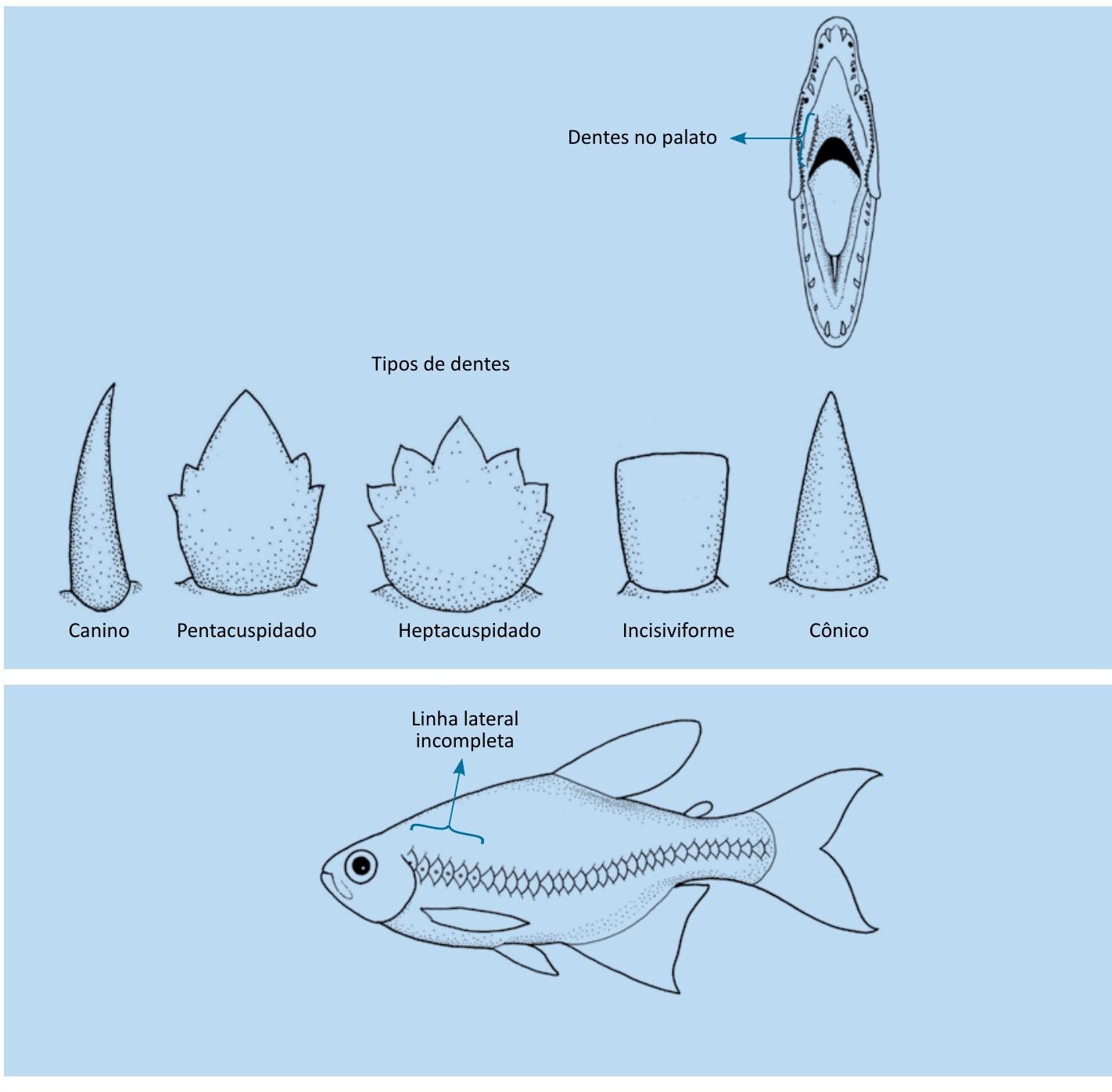


48. Dentes presentes no palato; dentes do pré-maxilar cônicos e numerosos

Oligosarcus (Characidae)

p. 88

48'. Dentes ausentes no palato; dentes do pré-maxilar incisiviformes nos adultos e em número máximo de quatro Leporinus (Anostomidae)

p. 64

49. Linha lateral incompleta 50

49’. Linha lateral completa 51

50. Corpo alto, sua altura contida menos de três vezes no comprimento padrão; colorido do corpo de padrão reticulado, com a borda das escamas escurecida; nadadeira anal curta, com menos de 25 raios; origem da nadadeira dorsal anterior à vertical da origem da nadadeira anal Hyphessobrycon (Characidae)

p. 87

50'. Corpo baixo, sua altura contida mais de três vezes no comprimento padrão; colorido do corpo não reticulado; nadadeira anal longa, com mais de 30 raios; origem da nadadeira dorsal posterior à vertical da origem da nadadeira anal Mimagoniates (Characidae) 
Três séries de dentes no pré-maxilar

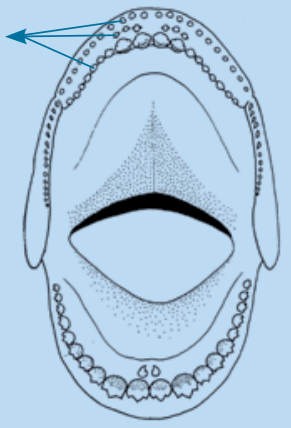

Duas séries de dentes no pré-maxilar

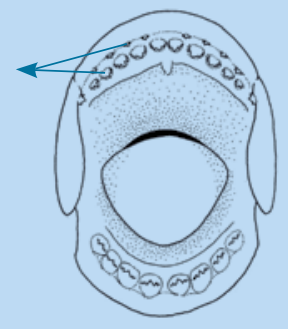


51. Três séries de dentes no pré-maxilar Brycon (Characidae)

p. 91

51'. Duas séries de dentes no pré-maxilar 52

52. Mais de 90 escamas na linha lateral; porte grande Salminus (Characidae)

52'. Menos de 45 escamas na linha lateral; porte pequeno

53. Apenas dentes cônicos ou caninos na maxila superior Gênero indeterminado (Characidae)

\section{p. 86}

53'. Dentes cuspidados na maxila superior 54

54. Quatro dentes na série interna do pré-maxilar; boca subterminal Bryconamericus (Characidae

54.' Quatro ou cinco dentes na série interna do pré-maxilar; boca terminal 55

55. Nadadeira pélvica com oito ou nove (raramente sete) raios; nadadeira dorsal com 11 (raramente 10) raios Astyanax (Characidae)

55'. Nadadeira pélvica com sete raios; nadadeira dorsal com 10 raios Cyanocharax (Characidae) 



\section{Ordem}

\section{CYPRINIFORMES}

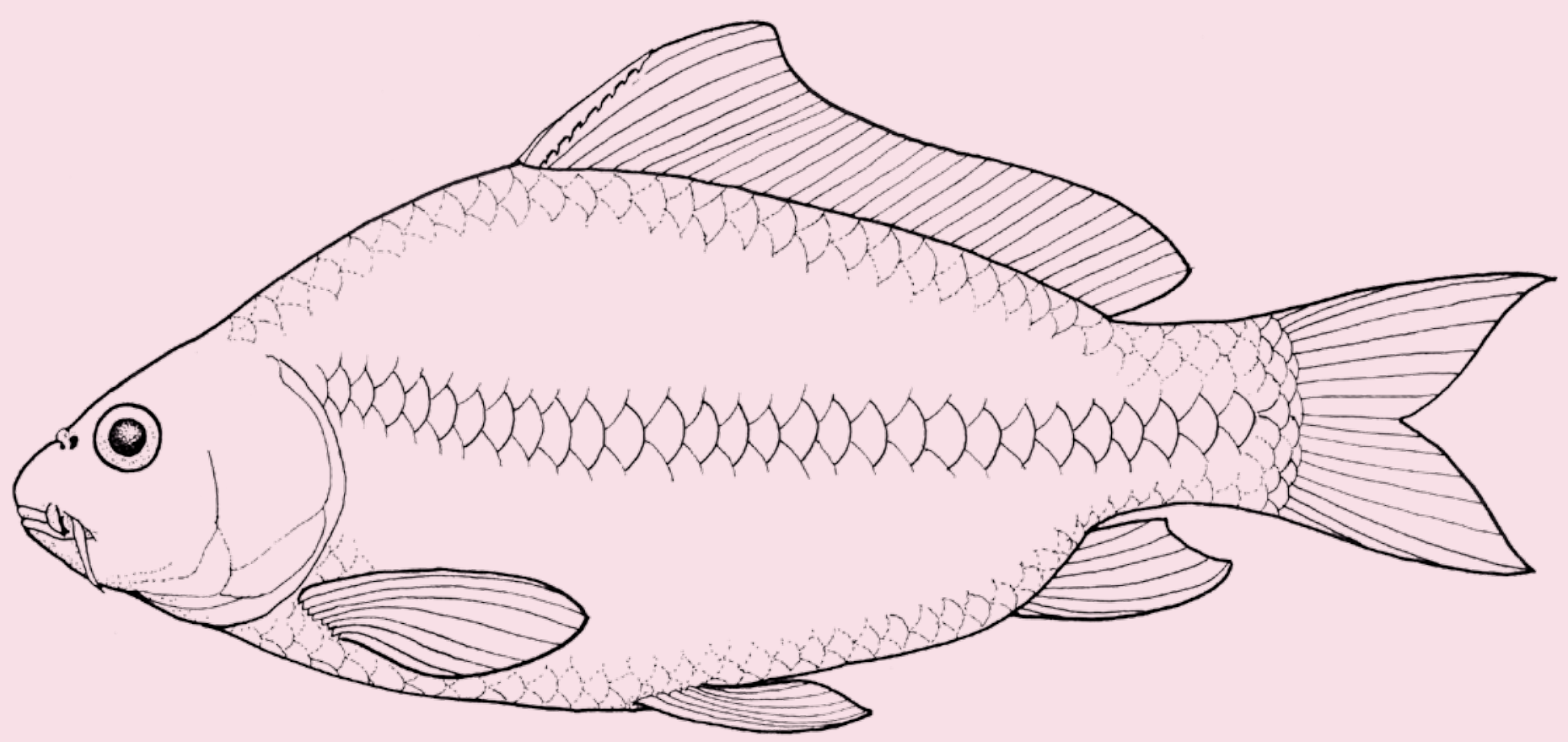

Com dentes ausentes nas maxilas, os representantes desta ordem geralmente possuem dentes faríngeos bem desenvolvidos. Originários do continente Asiático, onde são muito diversos, os Cypriniformes não ocorrem naturalmente na América do Sul, nem na Austrália (NELSON, 2006). O registro de seus representantes no Brasil e na bacia do rio Iguaçu, consequentemente, é oriundo sobretudo de escapes de pisciculturas, visto que algumas espécies são cultivadas no Brasil e em vários outros países. 


\section{FAMÍLIA}

\section{Cyprinidae}




\section{FAMÍLIA}

\section{Cyprinidae}

A família Cyprinidae congrega mais de 220 gêneros e 2.420 espécies, considerada a mais ampla família de peixes de água doce do mundo. Apresentam dentes faríngeos, com uma a três séries de dentes, mas nunca mais do que oito dentes em cada série, lábios normalmente pequenos e borda superior da maxila limitada somente pela pré-maxila (NELSON, 2006).

- Ctenopharyngodon idella (Valenciennes, 1844) Carpa-capim

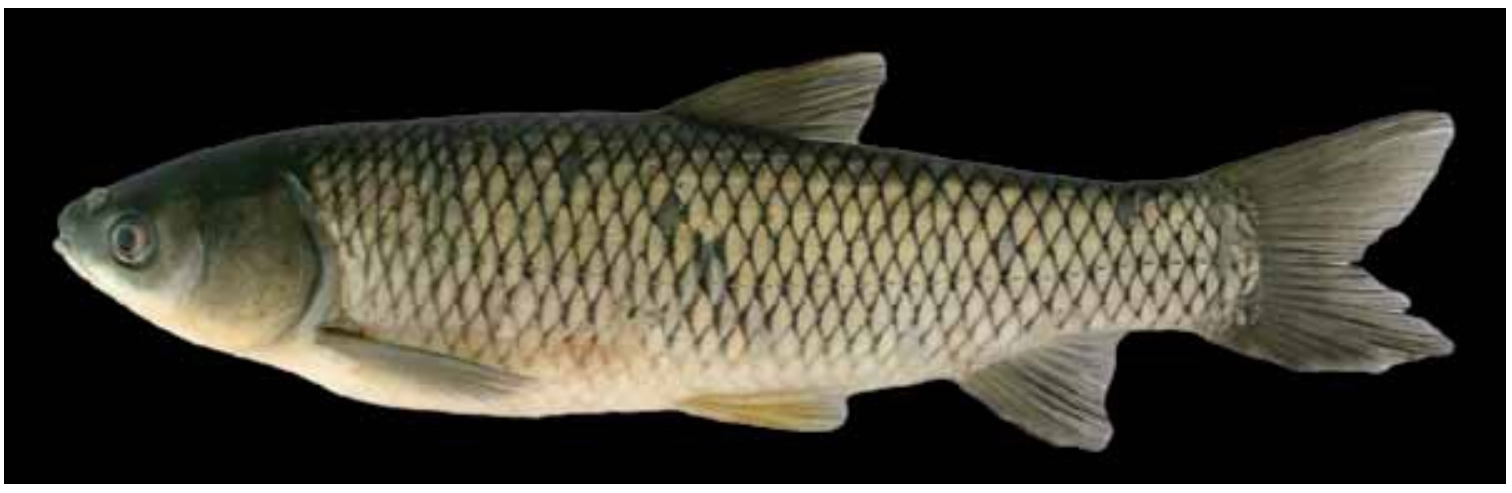

Comprimento padrão 228,4 mm

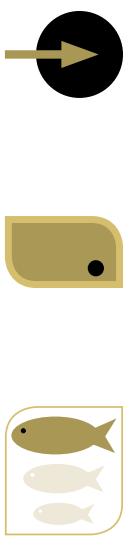

Região superior do corpo acinzentada. Ventre esbranquiçado ou amarelado. Sem faixas ou manchas evidentes na lateral do corpo. Nadadeiras hialinas apresentando poucos pigmentos escuros dispersos. Cabeça deprimida, sendo que a extremidade inferior do olho coincide com a horizontal que passa pela fenda bucal. Boca levemente subterminal.

Altura do corpo contida 3,5 a 3,7 e do pedúnculo caudal 7,7 a 7,9 vezes no CP; comprimento da cabeça contido 2,9 a 3,4 e do pedúnculo caudal 7,3 vezes no $C P$. Comprimento do focinho contido 3,8 a 3,9, diâmetro orbital 4,4 a 5,1 e distância interorbital 2,0 a 2,3 vezes no CC.

Maxilas sem dentes. Possui linha lateral completa com 40 escamas. Nadadeira dorsal com 9 raios, peitoral com 16 ou 17, pélvica com 8 e anal com 10 raios.

Nativa do oeste asiático, esta espécie, nas fases iniciais do seu ciclo de vida, alimenta-se de pequenos crustáceos e outros invertebrados, porém, quando adultos passam a alimentar-se de vegetação aquática (SIGLER; SIGLER, 1987). Espécie não indígena do Brasil, é cultivada em tanques de piscicultura em algumas regiões, incluindo a do rio Iguaçu. Sua ocorrência na bacia é atribuída aos escapes de pisciculturas. 


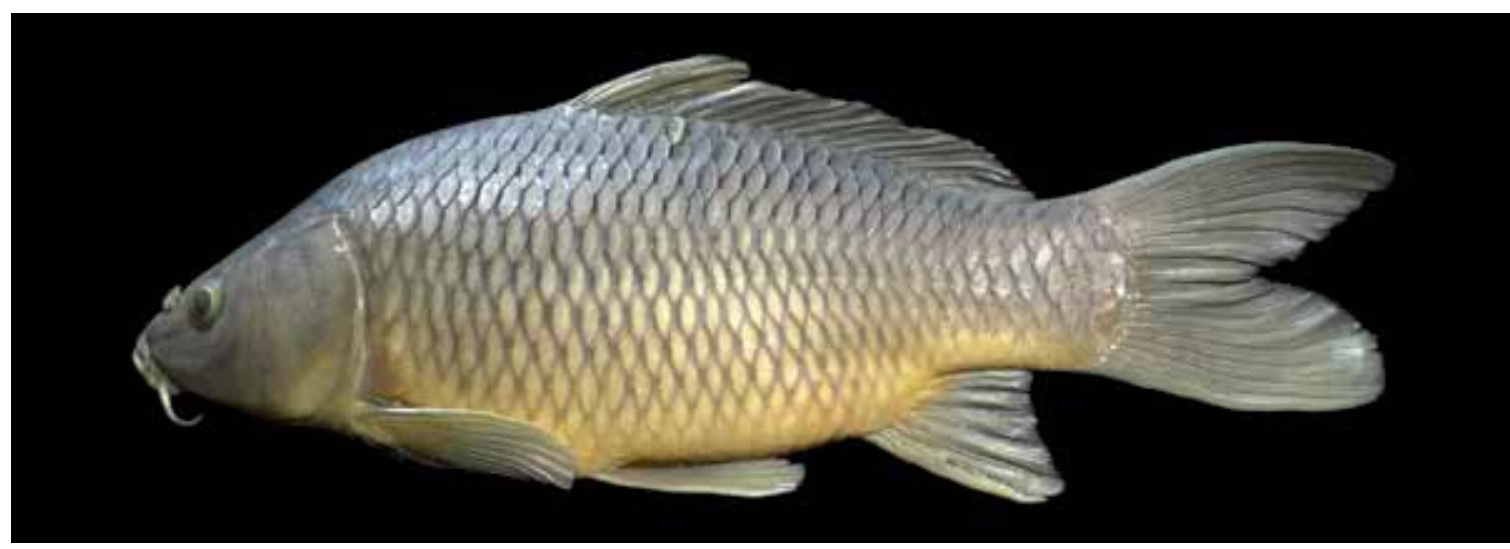

Comprimento padrão 274,0 mm

Região superior do corpo acinzentada. Ventre esbranquiçado ou amarelado. Sem faixas ou manchas evidentes na lateral do corpo. Nadadeiras hialinas apresentando poucos pigmentos escuros dispersos. Indivíduos dessa espécie podem apresentar o corpo total ou parcialmente coberto por escamas. No segundo caso, as escamas apresentam dimensões maiores e distribuem-se irregularmente sobre o corpo. Extremidade inferior do olho acima da horizontal que passa pela fenda bucal. Boca levemente subterminal, com um par de barbilhões maxilares.

Altura do corpo contida 2,4 a 2,7 e do pedúnculo caudal 6,5 a 7,0 vezes no $C P$; comprimento da cabeça 3,2 a 3,6 e do pedúnculo caudal 6,5 a 7,9 vezes no CP. Comprimento do focinho contido 2,7 a 3,1, diâmetro orbital 3,4 a 5,1 e distância interorbital 2,6 a 3,2 vezes no CC.

Maxilas sem dentes. Possui linha lateral completa, quando revestido uniformemente de escamas, com 36 a 38 escamas. Nadadeira dorsal iii $+\mathrm{I}+20$ a 22 raios, peitoral com 16 a 17, pélvica com 9 e anal com i ou ii $+\mathrm{I}+6$ raios.

Espécie nativa da Ásia é cultivada em algumas regiões do Brasil. No rio Iguaçu, sua alimentação é constituída basicamente de vegetais superiores (HAHN; FUGI; ALMEIDA; RUSSO; LOUREIRO, 1997), caracterizando-a como herbívora. A atividade reprodutiva ocorre em indivíduos com $\mathrm{L}_{50}=244,0 \mathrm{~mm}$ nos machos e $\mathrm{L}_{50}=365,0 \mathrm{~mm}$ nas fêmeas. No reservatório de Segredo essa atividade foi observada entre setembro e janeiro (SUZUKI; AGOSTINHO, 1997). 
Chave para espécies de Hypophthalmichthys

Baseada em Kolar, Chapman, Courtenay, Housel, Willians, Jennyngs (2005).

1. Olhos em posição lateral, mas pouco visíveis em vista ventral; quilha ventral iniciando bem anteriormente, quase no istmo; rastros branquiais finos, longos e fundidos, conferindo um aspecto esponjoso H. molitrix

1'. Olhos em posição lateral, mas ventralmente orientados, muito visíveis em vista ventral; quilha ventral iniciando na região entre a origem das nadadeiras pélvicas; rastros branquiais finos e longos, mas não fundidos H. nobilis

\section{- Hypophthalmichthys molitrix (Valenciennes, 1844) Carpa-prateada}

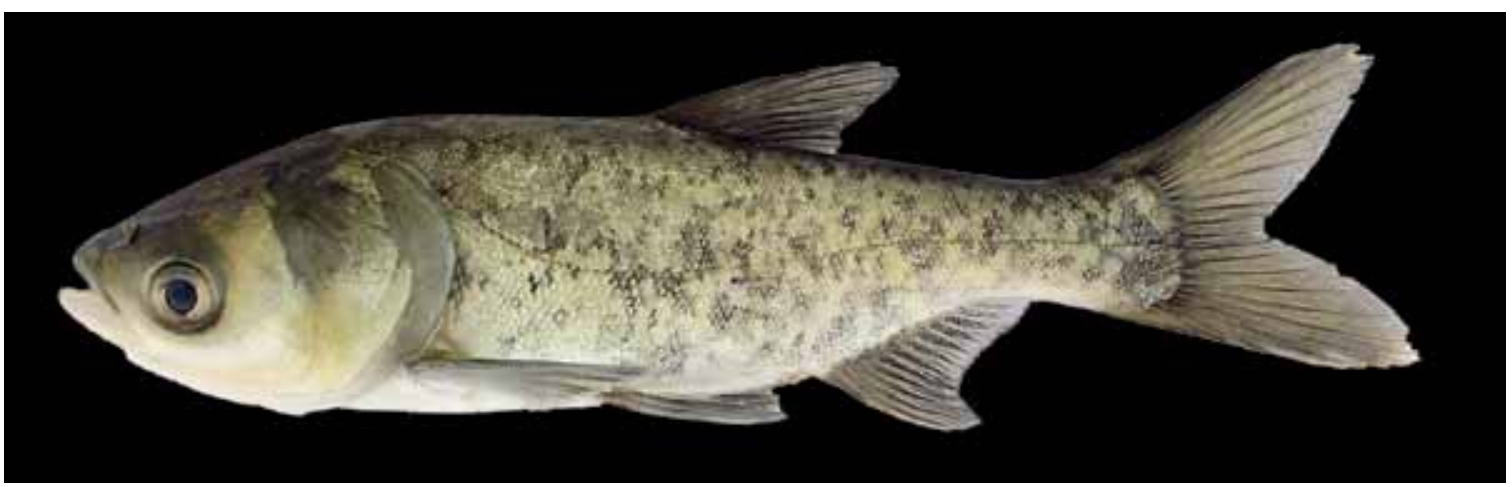

Comprimento padrão 179,7 mm

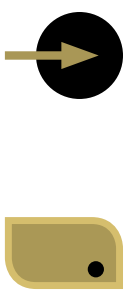

Região superior do corpo acinzentada, esverdeada ou castanho-escura, mais escura sobre a cabeça. Ventre esbranquiçado ou amarelado. Sem faixas ou manchas evidentes na lateral do corpo dos adultos. Nadadeiras de coloração variável desde hialinas a com muitos pigmentos escuros dispersos, sendo que a base da nadadeira caudal é mais escura do que as extremidades. Olhos laterais, pouco visualisados em vista ventral.

Altura do corpo contida 3,4 e do pedúnculo caudal 7,8 vezes do CP; comprimento da cabeça contido 2,8 e do pedúnculo caudal 7,3 vezes no CP. Comprimento do focinho contido 3,5, diâmetro orbital 5,6 e distância interorbital 2,8 vezes no CC.

Maxilas sem dentes. Possui linha lateral completa com 97 a 102* escamas. Nadadeira dorsal com 9 raios, peitoral com 18, pélvica com 8 e anal com 15 raios.

Espécie não indígena do Brasil, é cultivada em tanques de piscicultura em algumas regiões, incluindo a do rio Iguaçu. Sua ocorrência na bacia é atribuída aos escapes de pisciculturas.

*Etnier e Starnes (1993) 


\section{- Hypophthalmichthys nobilis (Richardson, 1845)}

Carpa-cabeçuda, carpa-cabeça-grande

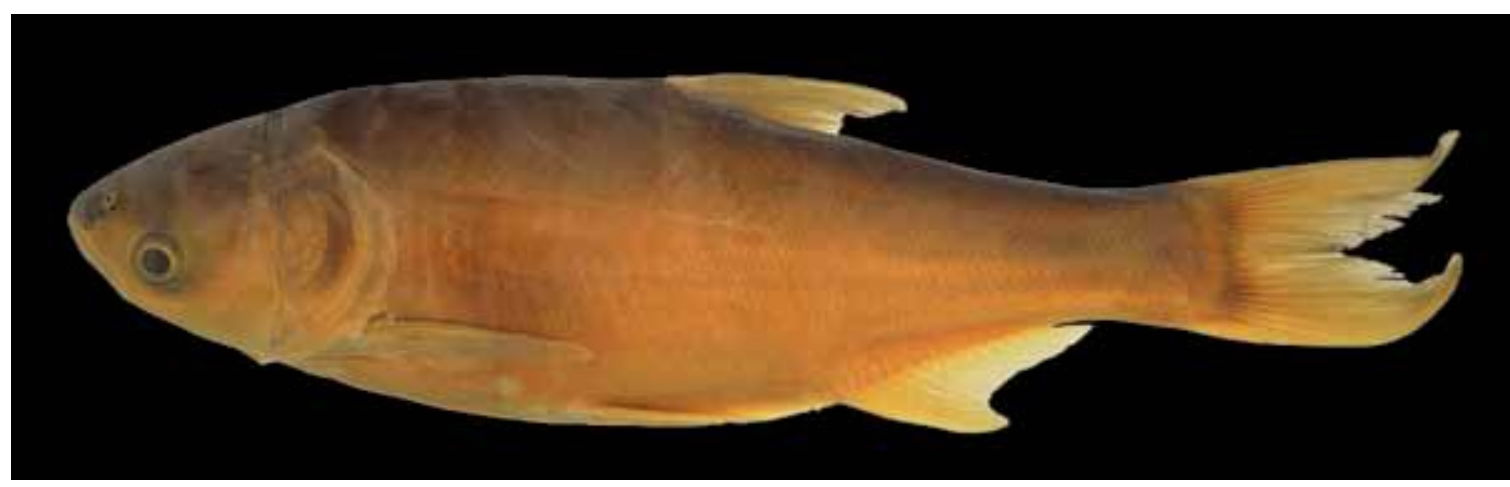

Comprimento padrão 193,8 mm

Região superior do corpo acinzentada, esverdeada ou castanho-escura, mais escura sobre a cabeça. Ventre esbranquiçado ou amarelado. Pintas acinzentadas numerosas, às vezes pouco conspícuas, visualizadas em exemplares recém coletados. Nadadeiras com muitos pigmentos escuros dispersos. Apresentam pigmentos escuros por todo o corpo e nadadeiras. Olhos laterais com orientação ventral, podendo ser visualizados em vista ventral.

Altura do corpo contida 3,2 a 3,7 e do pedúnculo caudal 7,9 a 10,4 vezes no CP; comprimento da cabeça contido 3,0 a 3,2 e do pedúnculo caudal 5,4 a 6,8 vezes no CP. Comprimento do focinho contido 3,4 a 3,9, diâmetro orbital 5,4 a 7,5 e distância interorbital 2,1 a 2,4 vezes no CC.

Maxilas sem dentes. Possui linha lateral completa com 91 a 103* escamas. Nadadeira dorsal com 9 raios, peitoral com 20, pélvica com 9 e anal com 15 raios.

Considerada um dos grandes filtradores de águas interiores, essa espécie apresenta seus rastros branquiais altamente especializados, com capacidade de reter partículas com tamanho de 4 mícrons (ETNIER; STARNES, 1993). Espécie não indígena do Brasil, é cultivada em tanques de piscicultura em algumas regiões, incluindo a do rio Iguaçu. Sua ocorrência na bacia é atribuída aos escapes de pisciculturas.

*Etnier e Starnes (1993) 


\section{Ordem}

\section{CHARACIFORMES}

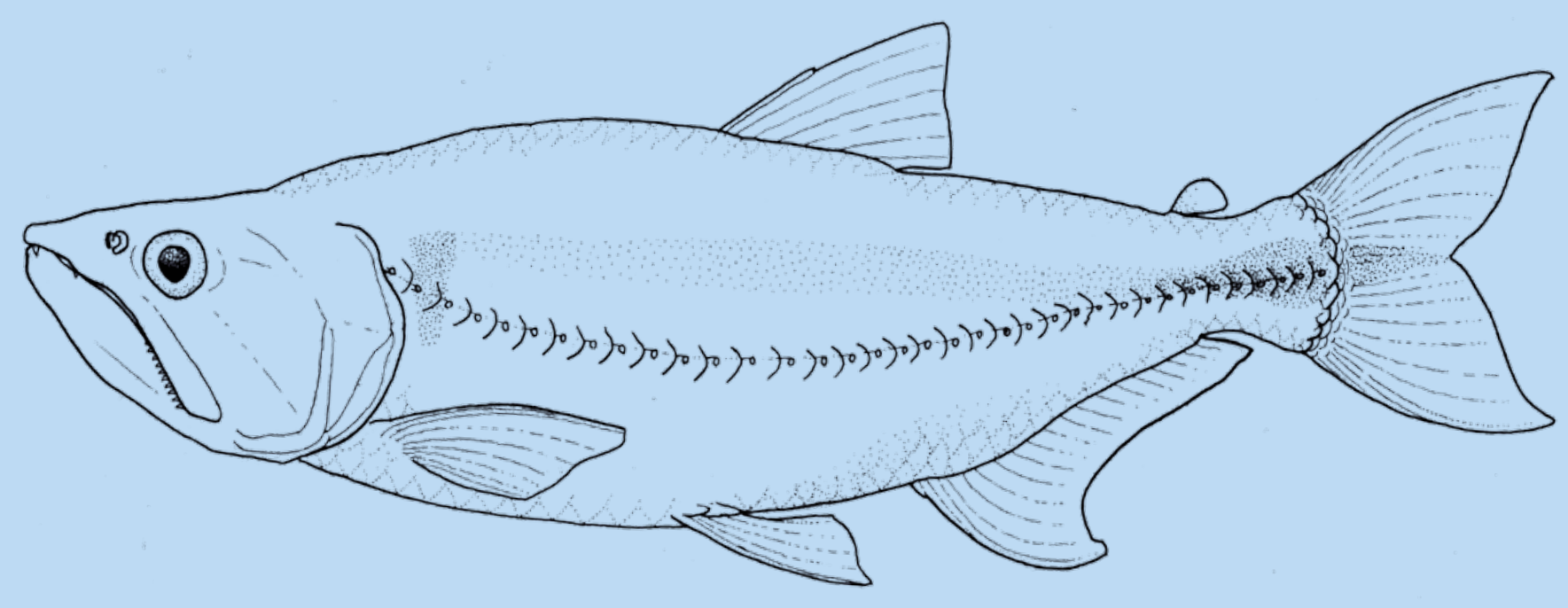

Ordem grandemente representada na região neotropical, possui muitas espécies na bacia do rio Iguaçu. Engloba os peixes com o corpo coberto por escamas ciclóides e com as nadadeiras pélvicas em posição abdominal. Embora com gêneros muito ricos em espécies nesta bacia, outros presentes na bacia do rio Paraná estão ausentes na fauna nativa do rio Iguaçu, incluindo os grandes migradores com importância comercial. Por outro lado, gêneros com muitas espécies no Iguaçu, quando comparados com o rio Paraná, apresentam espécies de porte maior e muito abundantes, como é o caso dos lambaris do gênero Astyanax. 0 endemismo da ictiofauna do rio Iguaçu é marcante nas espécies desta ordem, mas também várias espécies não nativas têm sido introduzidas acidental ou deliberadamente na bacia. 
FAMÍLIAS

Parodontidae

Curimatidae

Prochilodontidae

Anostomidae

Crenuchidae

Serrasalmidae

Characidae

Salmininae

Bryconinae

Stevardiinae

Erythrinidae 


\section{FAMÍLIA}

\section{Parodontidae}

Composta por três gêneros atualmente, a família possui somente um representante no rio Iguaçu. Seus exemplares são de pequeno porte, possuem corpo fusiforme, boca subterminal, lábio inferior e fontanela ausentes. São geralmente encontrados em riachos de águas correntes, onde conseguem se manter próximos ou fixados a rochas (PAVANELLI, 2003). Alguns espécimes dessa família apresentam tubérculos nupciais sobre o focinho e região internasal durante o período reprodutivo (PAVANELLI, 1999).

- Apareiodon vittatus Garavello, 1977

Canivete

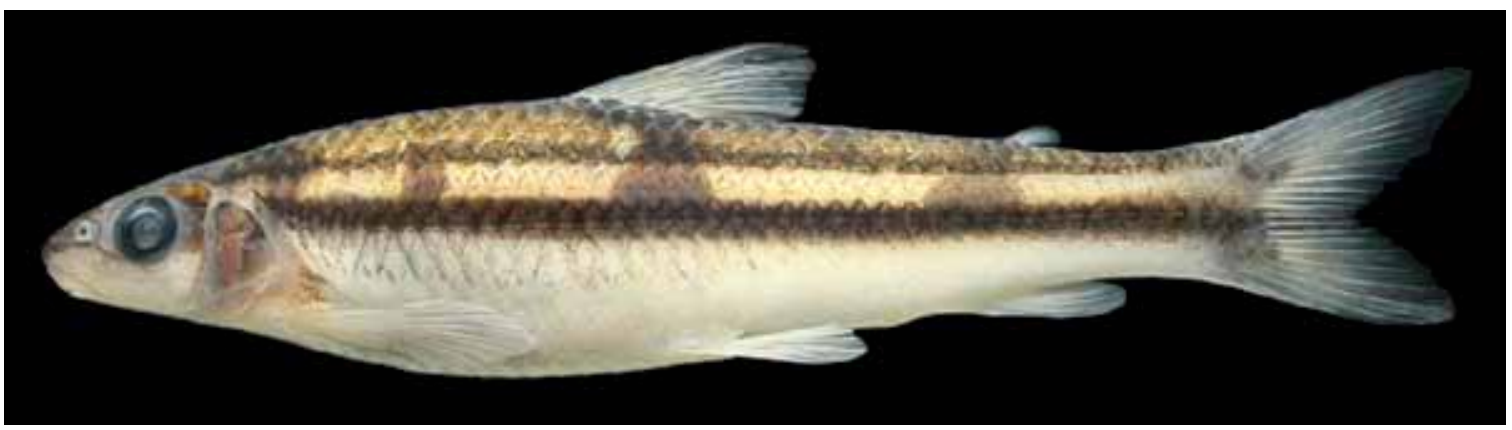

Comprimento padrão $77,0 \mathrm{~mm}$

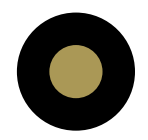

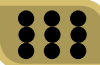

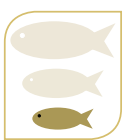

Região superior do corpo castanha-escura, uma faixa longitudinal preta sobre a linha lateral, que se prolonga sobre os raios caudais medianos, e outra mais estreita sobre a segunda fileira de escamas abaixo da nadadeira dorsal. Apresenta cinco a sete faixas escuras transversais largas, às vezes menos conspícuas, acima da faixa longitudinal principal. Ventre de coloração amarelo ou bege-claro, focinho proeminente em vista lateral, de comprimento semelhante à distância interorbital. Boca inferior, os dentes do pré-maxilar são espatulados, com várias cúspides distribuídas numa borda reta, arredondada nas laterais, e não possuem lábio.

Altura do corpo contida 3,8 a 4,5 e do pedúnculo caudal 7,3 a 9,7 vezes no CP; comprimento da cabeça contido 3,8 a 4,9, pré-dorsal 3,9 a 4,7 e do pedúnculo caudal 7,3 a 10,0 vezes no CP. Comprimento do focinho contido 2,7 a 3,2, diâmetro orbital 3,6 a 4,3 e distância interorbital 1,9 a 2,5 vezes no CC.

Possui $4^{*}$ dentes no pré-maxilar, com $11^{*}$ cúspides, e maxilar com $2^{*}$ dentes. Linha lateral completa com 38 a 40* escamas; $4^{*}$ séries de escamas acima da linha lateral e $3^{*}$ abaixo. Nadadeira dorsal com i+10 ou 11* raios, peitoral com i+12 a 14*, pélvica com $i+7^{*}$ e anal com $i+6$ ou $7^{*}$ raios. Apresenta 23 a $33^{*}$ rastros braquiais superiores e 30 a $36 *$ inferiores.

Espécie endêmica da bacia do rio Iguaçu, é encontrada com facilidade em vários ambientes. Com especializações anatômicas, como estômago mecânico, Apareiodon vittatus é considerada detritívora, podendo apresentar elevados índices de algivoria (HAHN; FUGI; ALMEIDA; RUSSO; LOUREIRO, 1997; DELARIVA, 2002). Os menores indivíduos em reprodução foram registrados com $C P=69,0 \mathrm{~mm}$ para machos e 
$\mathrm{CP}=73,0 \mathrm{~mm}$ para fêmeas (SUZUKI; AGOSTINHO, 1997). O período reprodutivo ocorre essencialmente de setembro a janeiro (UNIVERSIDADE ESTADUAL DE MARINGÁ, 2002; UNIVERSIDADE ESTADUAL DO OESTE DO PARANÁ, 2009a) e sua distribuição geográfica é restrita à bacia hidrográfica do rio Iguaçu (PAVANELLI, 2007).

*Garavello (1977)

\section{FAMÍLIA}

\section{Curimatidae}

Membros dessa família apresentam modificações em vários sistemas do corpo, principalmente relacionados à alimentação e respiração, podendo-se destacar alterações na boca, arcos branquiais e trato digestório. Nesse último, o estômago é transformado em moela, o que proporciona melhor aproveitamento da matéria orgânica, microdetritos, microvegetais e filamentos de algas. Seus exemplares apresentam porte pequeno, escamas ciclóides e os dentes são ausentes nos adultos (VARI, 2003).

- Cyphocharax cf. santacatarinae (Fernández-Yépez, 1948) Escrivão

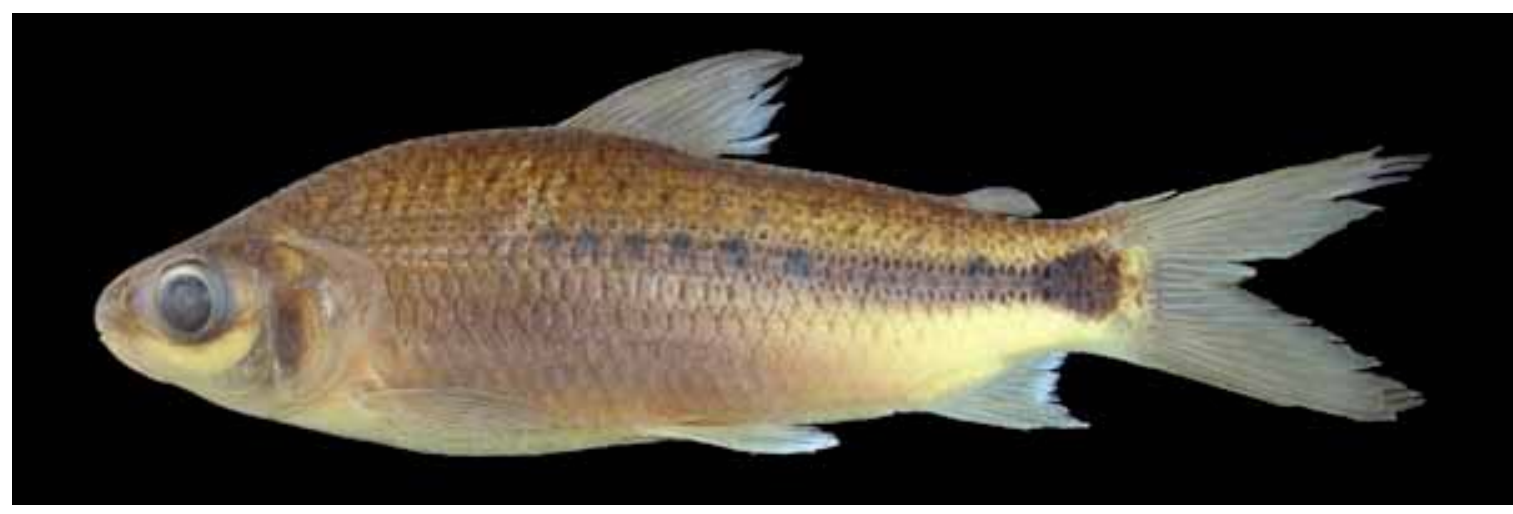

Comprimento padrão 110,5 mm

Prateado quando vivo, após fixado apresenta coloração cinza ou marrom-escuro na região dorsal do corpo e cabeça, com grande mancha cinza ou marrom-escura na lateral do pedúnculo caudal, em continuação a uma faixa longitudinal situada sobre a linha lateral, desde a região correspondente à origem da nadadeira dorsal, às vezes pouco conspícua. Manchas arredondadas marrom ou cinza-escuras podem ser visualizadas sobre a faixa longitudinal ou na região acima dela. Escamas com pigmentação escura um pouco mais evidente na borda, sobretudo na região acima da faixa longitudinal. Nadadeiras claras com poucos pigmentos escuros sobre os raios. Corpo moderadamente alongado, boca levemente subterminal, focinho arredondado em vista lateral.

Altura do corpo contida 2,5 a $2,9 *$ e do pedúnculo caudal 6,7 a $7,7^{*}$ vezes no $C P$; comprimento da cabeça contido 3,3 a 3,8*, pré-dorsal 1,9 a 2,0* e do pedúnculo caudal 9,7 a 10,0 vezes no CP. Comprimento do focinho contido 3,3 a 3,7*, diâmetro orbital 3,2 a $3,8^{*}$ e distância interorbital 2,2 a $2,4^{*}$ vezes no CC. 
Linha lateral completa com 32 a $34^{*}$ escamas; $5 \frac{1}{12^{*}}$ séries de escamas acima da linha lateral e $4 \frac{1}{2}$ ou $5^{*}$ abaixo. Nadadeira dorsal com ii-iii $+9^{*}$ raios, peitoral com 14 ou $15^{\star}$ pélvica com $\mathrm{i}+8^{*}$ e anal com ii-iii+7 ou $8^{*}$ raios.

Cyphocharax cf. santacatarinae é descrita de rios costeiros do Estado de Santa Catarina e distribui-se nas bacias costeiras do Estado de São Paulo a Santa Catarina (VARI, 1992). Embora não apareça na região do alto rio Iguaçu (INGENITO; DUBOC; ABILHOA, 2004) até o reservatório de Segredo (GARAVELLO; PAVANELLI; SUZUKI, 1997), tem sido capturada com facilidade no reservatório de Salto Caxias, onde foi identificada como C. modestus por Universidade Estadual de Maringá (2002). Sua ocorrência na bacia do baixo rio Iguaçu e ausência no médio e alto é inexplicada apenas com dados de distribuição geográfica. Embora seus caracteres coincidam sobremaneira com a redescrição de C. santacatarinae apresentada por Vari (1992), quando procedeu a revisão do gênero, aqui é utilizada a partícula cf., para que trabalhos futuros possam confirmar esta identificação. Fica aqui a sugestão de que análises moleculares comparativas entre a espécie do rio Iguaçu e das bacias adjacentes sejam conduzidas, a fim de confirmar esta identificação, sobretudo porque exemplares desta espécie da bacia do rio Iguaçu nunca foram incluídos anteriormente em trabalhos de cunho taxonômico.

A hipótese de transposição da espécie também não deve ser descartada, mas exemplares jovens e distribuição geográfica em vários ambientes foram encontrados logo nas primeiras coletas do projeto "Estudos ambientais na área de influência do reservatório de Salto Caxias", conduzido por Nupélia/UEM de março de 1997 a fevereiro de 2001, em convênio com a Copel, indicando que a espécie parece ser nativa ou estar plenamente estabelecida na região. Segundo Vari (1992), essa espécie encontra-se distribuída em rios costeiros do Estado do Paraná, Santa Catarina e sul de São Paulo. Também foi encontrada no rio Iguaçu em coletas realizadas por universidades paranaenses (UEM e UNIOESTE), onde foi identificada como C. modestus (BAUMGARTNER; BAUMGARTNER; PAVANELLI; SILVA; FRANA; OLIVEIRA; MICHELON, 2006).

A dieta dessa espécie é composta essencialmente por detritos do sedimento (detritívora), seu ritmo alimentar na calha principal do rio Iguaçu intensifica-se durante o outono, enquanto que em tributários é constante durante todo o ano. O período reprodutivo ocorre entre setembro e fevereiro e o tamanho de primeira maturação é de $L_{50}=97,0 \mathrm{~mm}$ nos machos e $L_{50}=102,0 \mathrm{~mm}$ nas fêmeas (UNIVERSIDADE ESTADUAL DE MARINGÁ, 2002). Segundo UNIVERSIDADE ESTADUAL DO OESTE DO PARANÁ (2008a) os menores indivíduos em reprodução apresentaram $C P=110,0 \mathrm{~mm}$ em fêmeas e $\mathrm{CP}=108,0 \mathrm{~mm}$ em machos.

*Vari (1992) 


\section{- Steindachnerina brevipinna (Eigenmann \& Eigenmann, 1889)} Saguiru

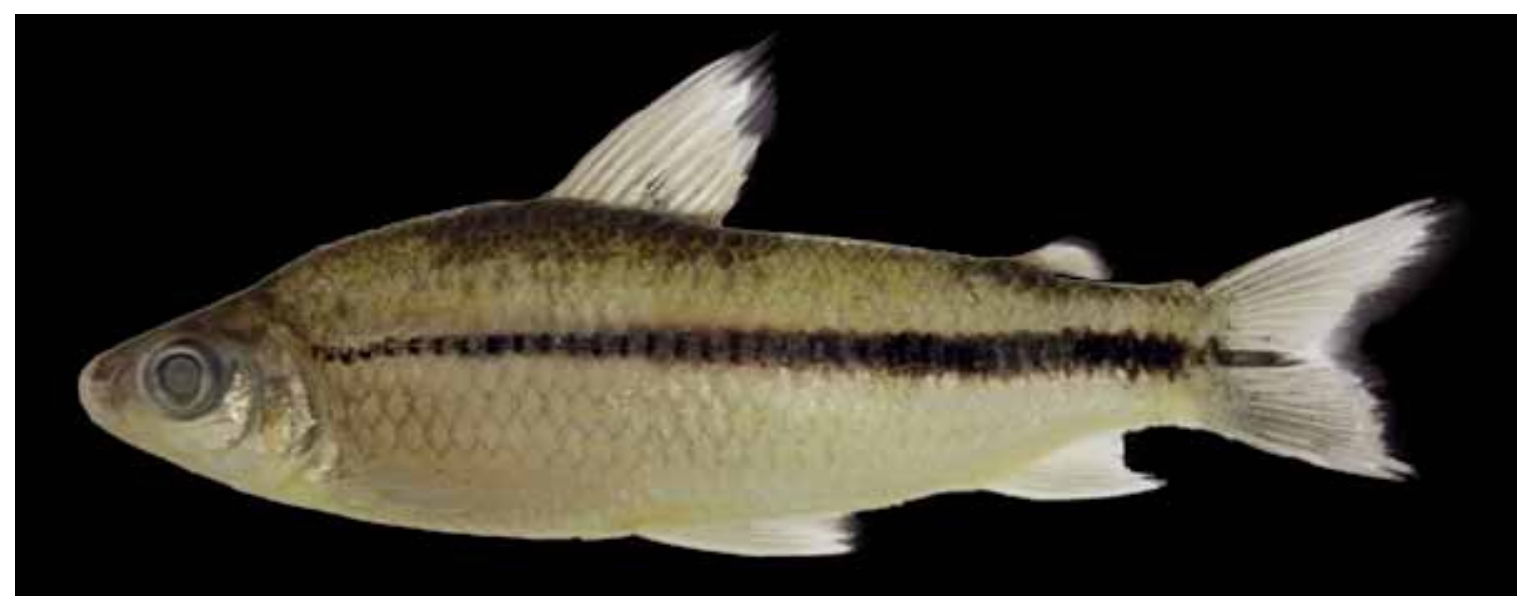

Comprimento padrão 95,0 mm

Corpo moderadamente alongado, perfil da cabeça reto ou ligeiramente côncavo. Região dorsal anterior do corpo com uma quilha mediana e região pré-pélvica levemente achatada. Coloração oliva-escuro na região dorsal. Pigmentação escura ao longo da linha lateral, formando uma faixa preta que se estende do pré-opérculo até o pedúnculo caudal, e se continua sobre os raios caudais medianos. Uma mancha preta entre o segundo e o quinto raio da nadadeira dorsal, próxima à base dos raios, às vezes pouco conspícua.

Altura do corpo contida 2,6 a 3,2* e do pedúnculo caudal 6,6 a 8,3* vezes no $C P$; comprimento da cabeça contido 3,1 a $3,7^{*}$, pré-dorsal 1,9 a $2,1^{*}$ e do pedúnculo caudal 8,3 a 9,3* vezes no CP. Comprimento do focinho contido 2,9 a 3,7*, órbita de 2,8 a 3,6* e distância interorbital 2,2 a 2,6* vezes no CC.

Linha lateral completa com 33 a $37^{*}$ escamas; $5 \frac{1 / 2}{2}$ a $6 \frac{1}{2} 2^{*}$ séries de escamas acima da linha lateral e $4 \frac{1}{2}$ a $5 \frac{1 / 2^{*}}{}$ abaixo. Nadadeira dorsal com ii +8 ou $9^{*}$, raramente iii $+9^{*}$ raios, peitoral com 12 a $14^{\star}$, pélvica com $\mathrm{i}+8^{\star}$ e anal com ii-iii $+7^{\star}$ raios.

Steindachnerina brevipinna é descrita do rio Paraguai, rio Paraná e baixo rio Uruguai (VARI, 1991), e sua ocorrência no rio Iguaçu foi registrada somente abaixo da usina de Salto Caxias, com poucos exemplares. Apresenta hábito alimentar detritívoro, alimentando-se exclusivamente de detrito finamente particulado e sedimento (GIORA; FIALHO, 2003). Não apresenta cuidado parental e a primeira maturação gonadal ocorre com $L_{50}=65,0 \mathrm{~mm}$ nos machos e $L_{50}=70,0 \mathrm{~mm}$ nas fêmeas (SUZUKI; VAZZOLER; MARQUES; LIZAMA; INADA, 2004). 


\section{FAMÍLIA}

\section{Prochilodontidae}

Sem espécies nativas da bacia do rio Iguaçu, possui apenas uma representante que ocorre raramente nas capturas, mas são muito apreciadas em outras bacias hidrográficas. Apresentam hábitos reprodutivos migratórios, podem atingir grande porte, possuem lábios carnosos bem desenvolvidos, o que lhes proporcionam sucesso na obtenção de alimento, grande quantidade de dentes diminutos, em forma de espátula, e nadadeira dorsal precedida por um espinho pequeno, simples ou bifurcado anteriormente (CASTRO; VARI, 2004). Espécies desta família são detritívoras e alimentam-se de matéria orgânica e microorganismos associados ao substrato de fundo (FUGI; HAHN; AGOSTINHO, 1996).

\section{- Prochilodus lineatus (Valenciennes, 1836)} Curimba

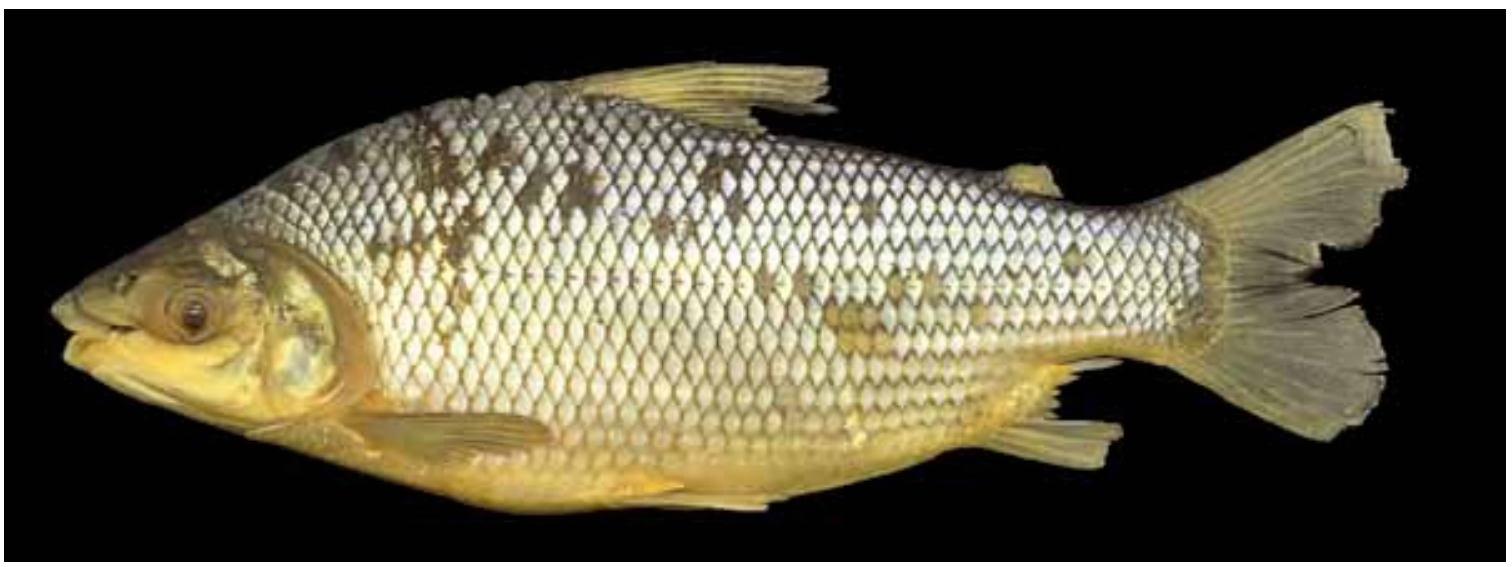

Comprimento padrão 262,2 mm

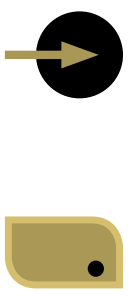

Prateado quando vivo, região dorsal do corpo cinza mais escuro que a ventral, que é esbranquiçada. Corpo moderadamente alto, comprimido, perfil dorsal da cabeça levemente côncavo, perfil dorsal do corpo convexo antes da nadadeira dorsal. Boca terminal, com lábios protráteis, comprimento do focinho maior que o diâmetro ocular. Lábios bem desenvolvidos, formando um disco oral quando protraídos. Dentes pequenos e numerosos implantados nos lábios. Nadadeiras hialinas ou esbranquiçadas, às vezes com pintas cinza-escuras, sobretudo nos exemplares jovens.

Altura do corpo contida 2,2 a 3,3* e do pedúnculo caudal 6,8 a 9,3* vezes no CP; comprimento da cabeça contido 2,7 a $4,3^{*}$, pré-dorsal 1,9 a $2,5^{*}$ e do pedúnculo caudal 6,5 a 9,4* vezes no CP. Comprimento do focinho contido 2,1 a 3,1*, diâmetro orbital 3,3 a 6,7* e distância interorbital 1,7 a $2,1^{*}$ vezes no CC.

Seus dentes são funcionais e dispõem-se em duas fileiras em cada maxila, sendo a fileira interna em forma de $V$, com 13 a 25* dentes na hemissérie superior e 9 a $18^{*}$ na inferior. Fileira externa de dentes em ambas as maxilas disposta na margem externa dos lábios, aproximadamente $95^{*}$ dentes na hemissérie superior e aproximadamente $75^{*}$ na inferior. Linha lateral completa com 44 a 50* escamas, 7 a 10* séries de escamas acima da linha lateral e 6 a 9* abaixo. Nadadeira dorsal com iii+9 ou 10* raios, peitoral 
com i+13 a $18^{*}$, pélvica com i+7 ou $8^{*}$, e anal com iii+7 a 9*, raramante $\mathrm{ii}+8^{*}$ raios.

Essa espécie até pouco tempo não havia sido registrada no rio Iguaçu, mas, nos últimos anos, vêm sendo registrados exemplares no reservatório de Salto Caxias (UNIVERSIDADE ESTADUAL DE MARINGÁ, 2002) e no reservatório de Foz do Areia (UNIVERSIDADE ESTADUAL DO OESTE DO PARANÁ, 2008a). Possivelmente, essa espécie tenha sido introduzida no rio Iguaçu por escape de tanques de piscicultura. No alto rio Paraná, P. lineatus possui hábito alimentar detritívoro (HAHN; FUGI; LOUREIRO-CRIPPA; PERETTI; RUSSO, 2004), não apresenta cuidado parental, reproduz-se principalmente entre outubro e abril e seus indivíduos iniciam a atividade reprodutiva com $L_{50}=213,0 \mathrm{~mm}$ nos machos e $L_{50}=240,0 \mathrm{~mm}$ nas fêmeas, sendo que seus exemplares realizam grandes migrações reprodutivas (SUZUKI; VAZZOLER; MARQUES; LIZAMA INADA, 2004). Essa espécie possui ampla distribuição geográfica em toda a bacia do rio Paraná-Paraguai e nas bacias dos rios Paraíba do Sul, Uruguai e Jacuí (CASTRO; VARI, 2007).

*Castro e Vari (2004)

\section{FAMÍLIA}

\section{Anostomidae}

Essa família caracteriza-se por apresentar exemplares de pequeno a grande porte, de corpo alongado e fusiforme, com uma única série com três ou quatro dentes no pré-maxilar e hemissérie do dentário, maxilar pequeno e sem dentes, e boca relativamente pequena (GARAVELLO; BRITSKI, 2003). Exemplares dessa família são importantes na pesca comercial em outras bacias hidrográficas, onde ocorrem em abundância. Representantes desta família capturados na bacia do rio Iguaçu não são nativos. Seus hábitos alimentares os qualificam como onívoros, utilizando principalmente invertebrados, vegetais e frutos como base da sua alimentação.

\section{Chave para espécies de Leporinus}

1. Corpo com oito faixas transversais pretas L. octofasciatus

1'. Corpo sem faixas transversais, mas com manchas pretas evidentes

2. Pré-maxilar e dentário com quatro dentes L. friderici

2'. Pré-maxilar e dentário com três dentes 3

3. Boca subterminal, fenda bucal abaixo da horizontal que passa pela borda inferior do olho L. aff. elongatus

3'. Boca terminal 4

4. Raio mais longo da nadadeira anal maior do que o dobro do comprimento do último raio

L. obtusidens

4'. Raio mais longo da nadadeira anal menor do que o dobro do comprimento do último raio

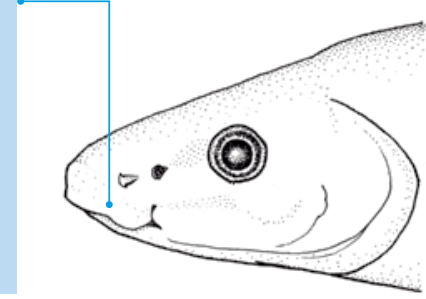




\section{- Leporinus aff. elongatus Valenciennes, 1850}

Piapara

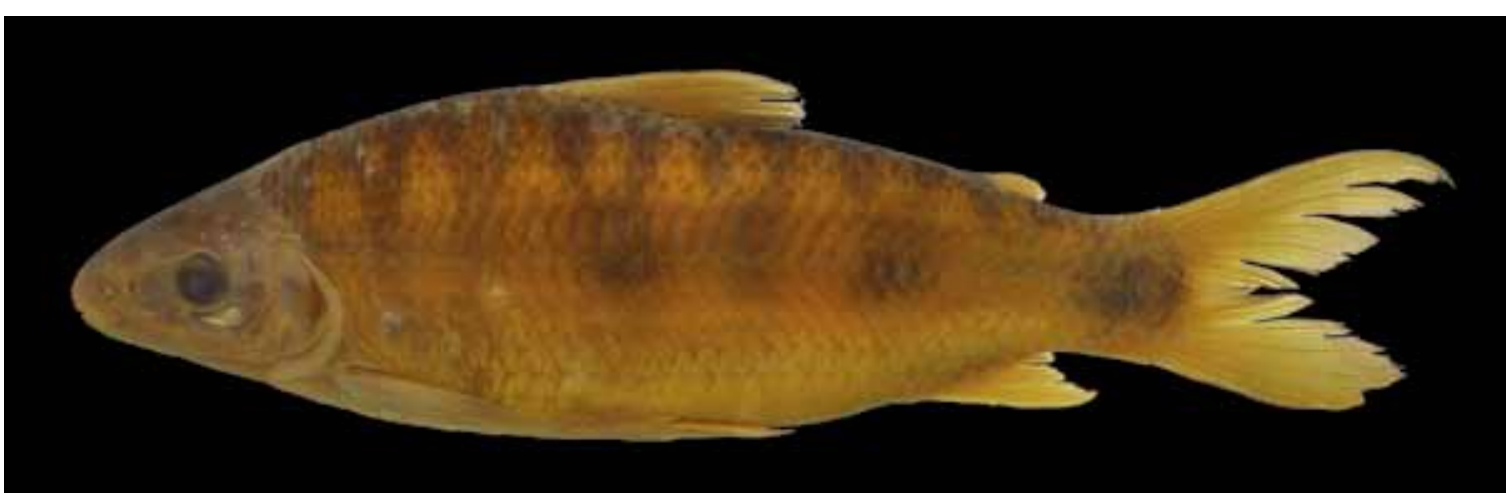

Comprimento padrão 194,9 mm

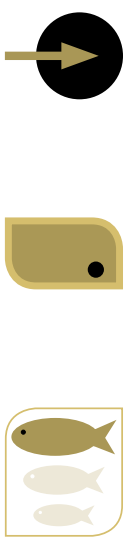

Região superior do corpo castanha, ventral amarelo-clara, com largas faixas transversais cinzas, às vezes inconspícuas ou mais evidentes na região mais dorsal, e três grandes manchas pretas na lateral do corpo. Nadadeira dorsal amarelada ou bege-clara, demais nadadeiras levemente amareladas e a anal ligeiramente escurecida. Quando em vida podem apresentar as nadadeiras amarelo vivo ou alaranjadas, sobretudo as pélvicas e anal. Possui corpo alongado e comprimido, boca subterminal, com lábio superior proeminente, cuja horizontal da fenda bucal passa abaixo da órbita, a qual possui a margem superior horizontalmente em linha com a linha lateral.

Altura do corpo contida 3,2 a 3,5* e do pedúnculo caudal 8,6 a 8,9* vezes no CP; comprimento da cabeça contido 3,2 a $3,8^{*}$, pré-dorsal 2,0 a $2,1^{*}$ e do pedúnculo caudal 7,0 a 7,9* vezes no CP. Comprimento do focinho contido 2,0 a 2,2* diâmetro orbital 2,9 a 3,8* e distância interorbital 6,7 a 8,4* vezes no CC.

Possui $3^{*}$ dentes no pré-maxilar e $3^{*}$ na hemissérie do dentário. Linha lateral completa com 41 a 44* escamas, 6 a $7^{*}$ séries de escamas acima da linha lateral e $6^{*}$ abaixo. Nadadeira dorsal com i+11* raios, peitoral com $i+15$ ou $16^{*}$, pélvica com $i+9 *$, e anal com ii $+9 *$ raios.

Essa espécie foi identificada por Garavello (1979) como Leporinus obtusidens (Valenciennes, 1837). Amplamente distribuída nas bacias dos rios Paraná-Paraguai, a 'piapara', identificada de longa data como Leporinus elongatus Valenciennes, 1850, parece ser restrita à bacia do rio Jequitinhonha e talvez também à do São Francisco (BRITSKI; GARAVELLO, 2007). Portanto, utilizamos aqui a partícula aff. Na planície de inundação do alto rio Paraná, essa espécie foi considerada como insetívora por Agostinho, Hahn, Gomes e Bini (1997). Não apresenta cuidado parental, realiza grandes migrações, se reproduz principalmente de outubro a fevereiro e inicia a atividade reprodutiva com $L_{50}=190,0 \mathrm{~mm}$ nos machos e $L_{50}=208,0 \mathrm{~mm}$ nas fêmeas (SUZUKI; VAZZOLER; MARQUES; LIZAMA; INADA, 2004). No rio Iguaçu ela não é nativa, sendo sua captura esporádica e restrita a exemplares adultos, indicando que sua ocorrência pode ser devida ao escape de pisciculturas.

*Graça e Pavanelli (2007) 


\section{- Leporinus friderici (Bloch, 1794) \\ Piau-três-pintas}

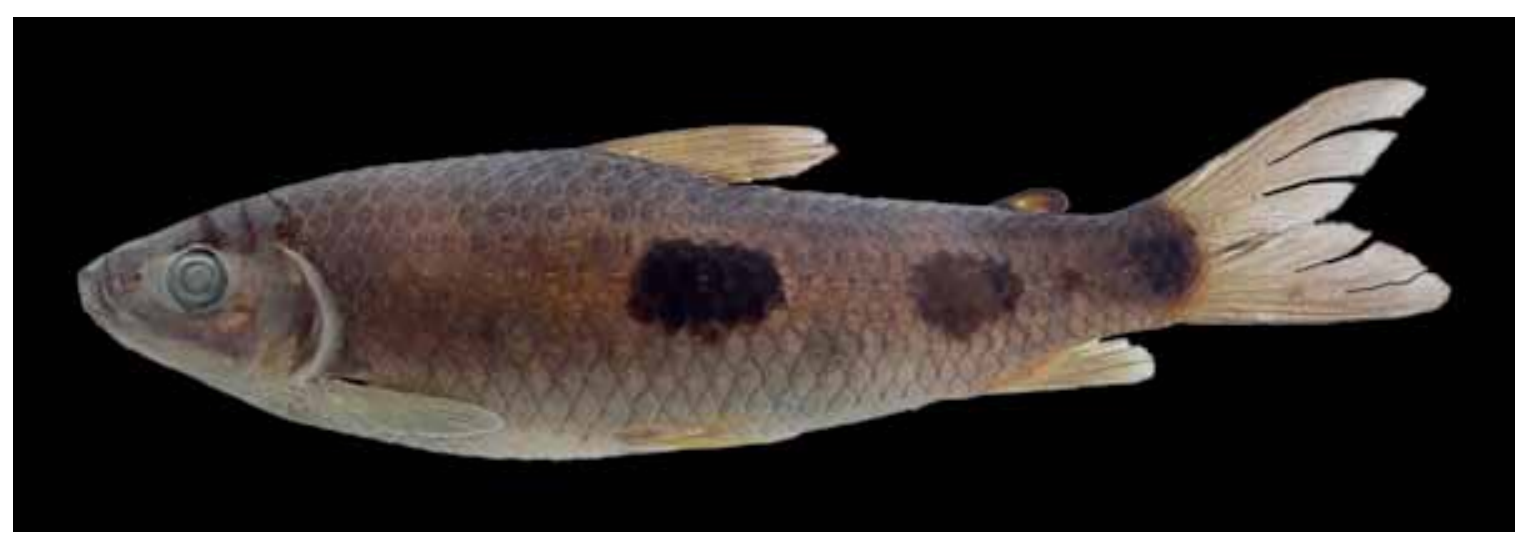

Comprimento padrão 197,8 mm

Região superior do corpo castanha, ventral amarelo-clara, com largas faixas transversais cinza-claras, mais evidentes nos exemplares jovens, e três grandes manchas pretas, horizontalmente alongadas na lateral do corpo. Nadadeira dorsal hialina, demais nadadeiras amareladas e a anal levemente escurecida. Possui corpo alongado e comprimido, boca terminal. Quando vivo pode apresentar listras longitudinais alaranjadas na região anterior do flanco, abaixo da linha lateral, olho com região superior vermelha, assim como a região de contato de algumas escamas da região umeral, conferindo um tom avermelhado.

Altura do corpo contida 3,2 a 4,2* e do pedúnculo caudal 9,3 a $10,5^{*}$ vezes no $C P$; comprimento da cabeça contido 4,0 a 4,3*, pré-dorsal 2,1 a $2,3^{*}$ e do pedúnculo caudal 8,6 a $10,5^{*}$ vezes no CP. Comprimento do focinho contido 2,4 a 2,6*, diâmetro orbital 3,2 a 3,9* e distância interorbital 2,1 a $2,8^{*}$ vezes no CC.

Possui $4^{*}$ dentes no pré-maxilar e na hemissérie do dentário. Linha lateral completa com 37 a $40^{*}$ escamas, 4 a $5 \frac{1}{2} 2^{*}$ séries de escamas acima da linha lateral e 4 a $5 \frac{1}{2} 2^{*}$ abaixo. Nadadeira dorsal com $\mathrm{i}+11^{*}$ raios, peitoral com $\mathrm{i}+14$ a $16^{*}$, pélvica com $\mathrm{i}+8^{*} \mathrm{e}$ nadadeira anal com $\mathrm{i}+9 *$ raios.

Na bacia do alto rio Paraná é encontrada em rios e lagoas, alimenta-se de vegetais, insetos e peixes (ANDRIAN; DÓRIA; TORRENTE; FERRETI, 1994). Não possui cuidado parental, realiza pequenas migrações, se reproduz entre outubro e março e inicia sua reprodução com $L_{50}=131,0 \mathrm{~mm}$ nos machos e $L_{50}=162,0 \mathrm{~mm}$ nas fêmeas (SUZUKI; VAZZOLER; MARQUES; LIZAMA; INADA, 2004). Amplamente distribuída nas bacias de rios do Suriname, Guiana Francesa, Amazonas e do Prata (BRITSKI; GARAVELLO, 2007), não é nativa da bacia do rio Iguaçu. Sua ocorrência esporádica deve ser atribuída aos escapes de pisciculturas. 


\section{- Leporinus macrocephalus Garavello \& Britski, 1988 \\ Piavuçu, piaussu}

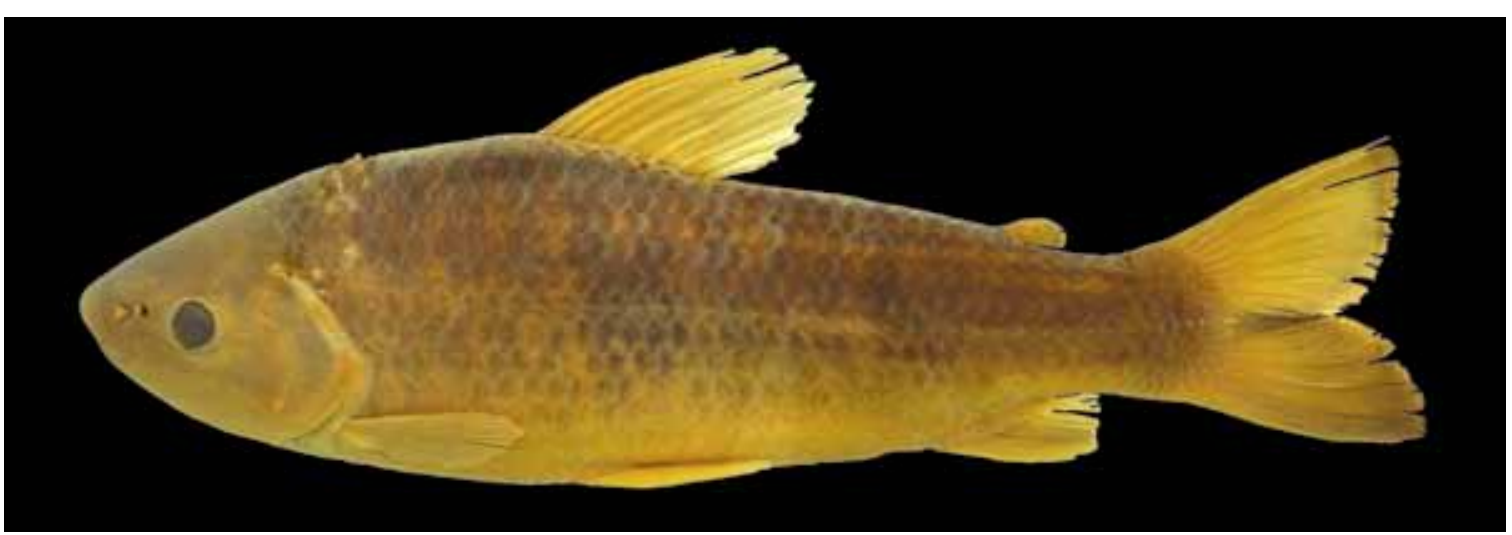

Comprimento padrão 240,9 mm

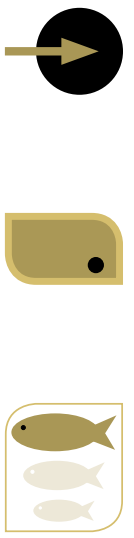

Região superior do corpo castanha, ventral amarelo-clara, com largas faixas transversais cinzas pouco conspícuas, e três grandes manchas pretas na lateral do corpo, mais evidentes nos jovens. Escamas com a borda escurecida, conferindo um aspecto reticulado ao corpo. Nadadeiras pares esbranquiçadas, ímpares com leve pigmentação cinza-escura, mais intensa na nadadeira anal. Possui corpo robusto e boca terminal.

Altura do corpo contida 3,0 a 3,5* e do pedúnculo caudal 8,1 a $8,9^{*}$ vezes no CP; comprimento da cabeça contido 2,5 a 3,0*, pré-dorsal $2,0^{*}$ e do pedúnculo caudal 4,9 a 6,6* vezes no CP. Comprimento do focinho contido 2,2 a 2,5*, diâmetro orbital 2,9 a $3,7^{*}$ e distância interorbital 1,7 a 1,9* vezes no CC.

Possui $3^{*}$ dentes no pré-maxilar e $3^{*}$ na hemissérie do dentário. Linha lateral completa com 42 ou $43^{*}$ escamas, $5 \frac{1}{1} 2$ ou $6^{*}$ escamas acima da linha lateral e 5 ou $5 \frac{1}{2} 2^{*}$ abaixo. Nadadeira dorsal com $\mathrm{i}+11^{*}$ raios, peitoral com $\mathrm{i}+15$ ou $16^{*}$, pélvica com $\mathrm{i}+8^{*}$ e anal com i+9* raios.

Amplamente distribuída nas bacias hidrográficas do rio Paraguai e médio rio Paraná (BRITSKI; GARAVELLO, 2007), é também capturada esporadicamente no rio Iguaçu (UNIVERSIDADE ESTADUAL DE MARINGÁ, 2002), possivelmente devido o escape de pisciculturas. 


\section{- Leporinus obtusidens (Valenciennes, 1837)}

Piau

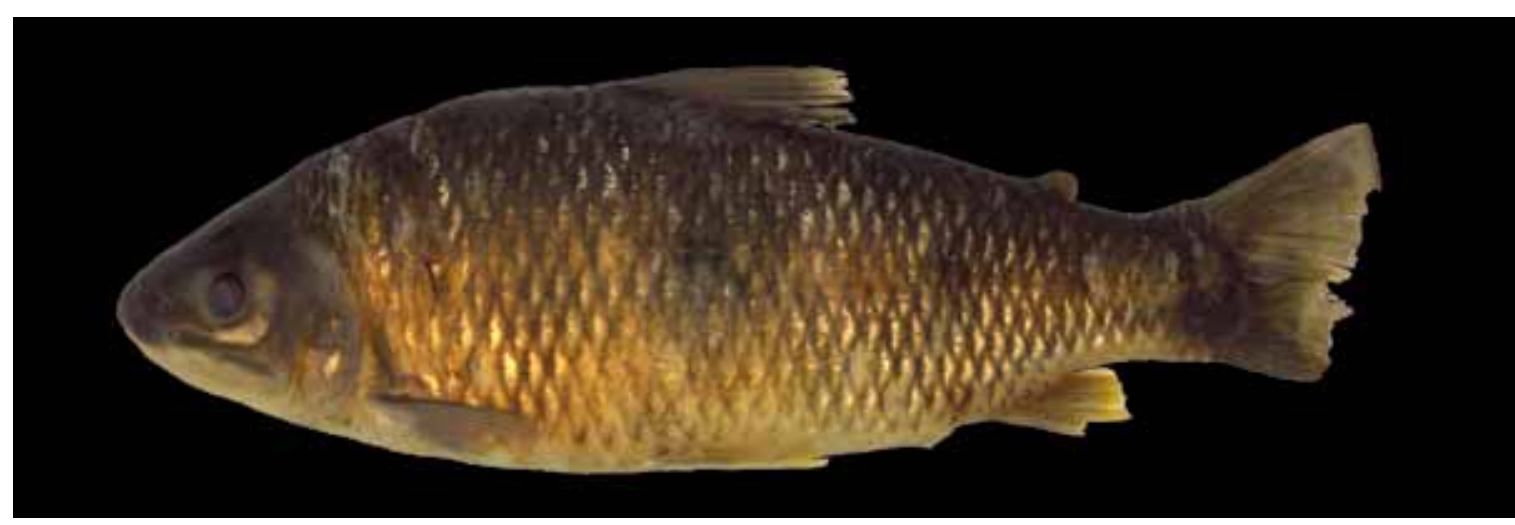

Comprimento padrão 225,7 mm

Região superior do corpo castanha, ventral amarelo-clara, com largas faixas transversais cinzas, às vezes inconspícuas ou mais evidentes na região mais dorsal, e três grandes manchas pretas na lateral do corpo. Nadadeira dorsal amarelada ou bege-clara, demais nadadeiras levemente amareladas e anal ligeiramente escurecida. Possui corpo alongado e comprimido, boca terminal, cuja horizontal da fenda bucal passa sobre a órbita, olho com margem superior horizontalmente em linha com a linha lateral. O raio mais longo da nadadeira anal é mais longo que o dobro do raio mais curto.

Altura do corpo contida 3,2 a $3,4^{*}$ e do pedúnculo caudal 8,6 a 9,3* vezes no $C P$; comprimento da cabeça contido 3,3 a 4,2*, pré-dorsal 2,1 a $2,2^{*}$ e do pedúnculo caudal 7,5 a $8,7^{*}$ vezes no CP. Comprimento do focinho contido 2,4 a 2,5* diâmetro orbital 2,4 a $2,5^{*}$ e distância interorbital 1,8 a 2,3* vezes no CC.

Possui $3^{*}$ dentes no pré-maxilar e $3^{*}$ na hemissérie do dentário. Linha lateral completa com 38 a $40^{*}$ escamas, 6 a $7^{*}$ séries de escamas acima da linha lateral e 5 a $6^{*}$ abaixo. Nadadeira dorsal com $i+11^{*}$ raios, peitoral com $i+15$ ou $16^{*}$, pélvica com $i+9^{*}$, e anal com $i+9^{*}$ raios.

Esta espécie foi identificada por Garavello (1979) como Leporinus silvestrii Boulenger, 1902. No alto rio Paraná alimenta-se de vegetais e insetos (ANDRIAN; DÓRIA; TORRENTE; FERRETI, 1994), realiza grandes migrações, sem cuidado parental, se reproduz entre outubro e fevereiro, iniciando a atividade reprodutiva com $L_{50}=161,0 \mathrm{~mm}$ nos machos e $L_{50}=216,0 \mathrm{~mm}$ nas fêmeas (SUZUKI; VAZZOLER; MARQUES; LIZAMA; INADA 2004). Ocorre em rios das bacias do Prata, São Francisco e Guaíba (BRITSKI; GARAVELLO, 2007), mas não é nativa do rio Iguaçu. A exemplo das demais congêneres, seus exemplares são capturados adultos e esporadicamente, sugerindo que sua ocorrência no Iguaçu possa ser fruto de escapes de pisciculturas. 


\section{- Leporinus octofasciatus Steindachner, 1915 \\ Piau, flamenguinho, ferreirinha}

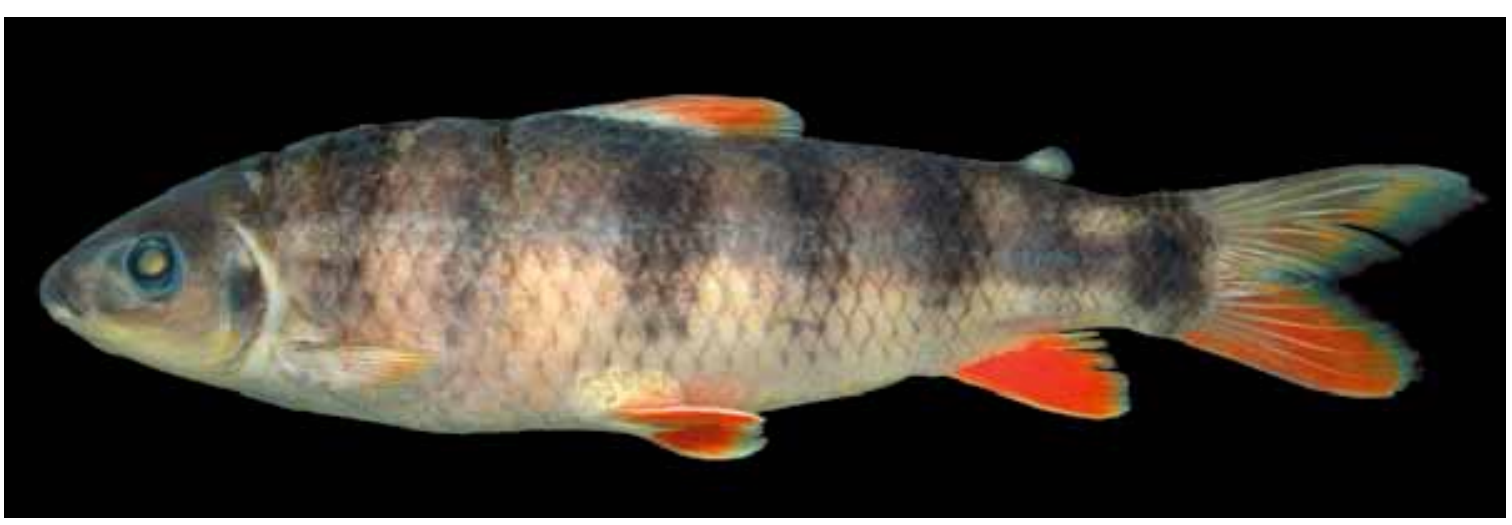

Comprimento padrão 190,0 mm

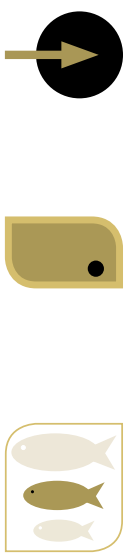

Região superior do corpo castanha, ventral amarelo-clara, com oito largas faixas transversais pretas na lateral do corpo. Quando em vida, apresenta as nadadeiras vermelhas ou alaranjadas. Possui corpo alongado e comprimido e boca levemente subterminal.

Altura do corpo contida 3,6 a 3,8* e do pedúnculo caudal 9,1 a 9,3* vezes no CP; comprimento da cabeça contido 3,1 a 4,3*, pré-dorsal 1,9 a $2,1^{*}$ e do pedúnculo caudal 9,2 a 9,3* vezes no CP. Comprimento do focinho contido 2,2 a 2,7* diâmetro orbital 4,0 a $4,2 *$ e distância interorbital 2,2 a 2,6 * vezes no CC.

Possui $3^{*}$ dentes no pré-maxilar e $4^{*}$ na hemissérie do dentário. Linha lateral completa com 35 a 39* escamas, 5* séries de escamas acima da linha lateral e 4 a $5^{*}$ abaixo. Nadadeira dorsal com i+11* raios, peitoral com i+15 ou $16^{*}$, pélvica com i+8*, e anal com ii+8 ou $9^{* *}$ raios.

Na bacia do alto rio Paraná, esta espécie alimenta-se de vegetais (LUZ-AGOSTINHO; BINI; FUGI; AGOSTINHO; JÚLIO JÚNIOR, 2006). Ocorre na bacia do rio Paraná e em Joinville, sua localidade-tipo, segundo Britski e Garavello (2007), porém, não é nativa do rio Iguaçu, onde ocorre esporadicamente.

**Britski e Garavello (1978); *Garavello (1979) 


\section{FAMÍLIA

Com exemplares de pequeno porte e corpo fusiforme, espécies dessa família são normalmente encontradas em riachos de água corrente, onde suas nadadeiras bem desenvolvidas proporcionam grande equilíbrio, mesmo em águas com grande correnteza. Além dessas características, os membros dessa família apresentam fontanela frontal ausente e fontanela parietal pequena e circular, dentes cônicos ou tricuspidados em apenas uma série no pré-maxilar, dois ou mais raios não ramificados na nadadeira peitoral e menos de 14 raios na anal (BUCKUP, 2003).

\section{Chave para espécies de Characidium}

1. Nadadeira adiposa presente Characidium sp. 1

1'. Nadadeira adiposa ausente Characidium sp. 2

- Characidium sp. 1 Charutinho

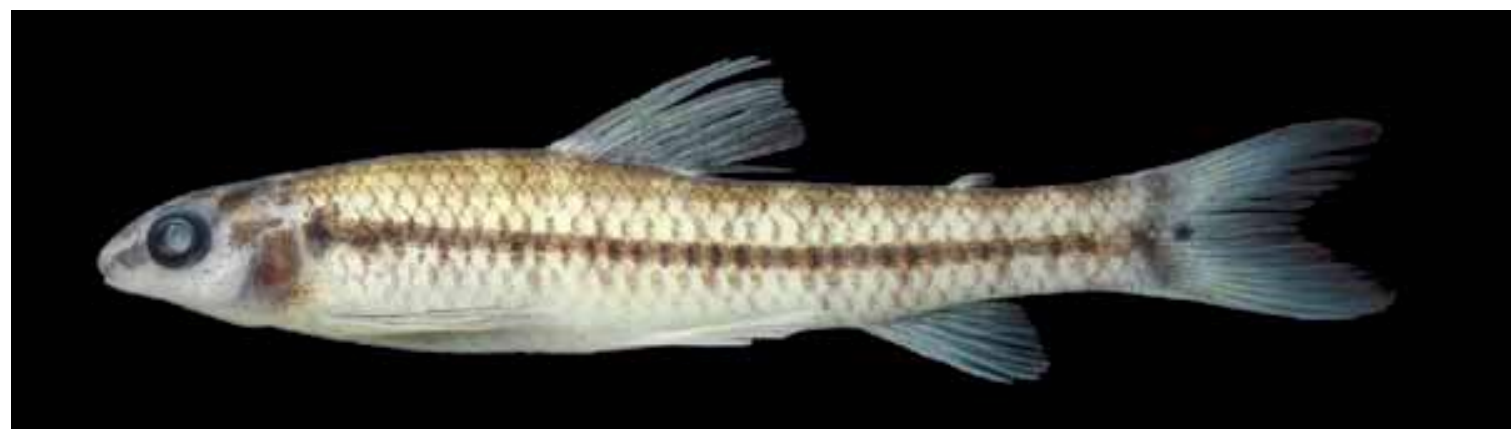

Comprimento padrão 49,0 mm

Corpo amarelo-claro, com uma faixa longitudinal marrom-escura bem evidente e oito a dez faixas transversais marrom-escuras, largas, às vezes esmaecendo em direção à região ventral. Nadadeiras hialinas, com poucos pigmentos escuros sobre os raios, apenas a caudal com uma pinta preta na base dos raios caudais medianos. Possui boca subterminal, istmo coberto por escamas, nadadeira adiposa, corpo baixo e alongado.

Altura do corpo contida 3,9 a 5,3 e do pedúnculo caudal 8,6 a 10 vezes no CP; comprimento da cabeça contido 4,2 a 5,2, pré-dorsal 2,2 a 2,3 e do pedúnculo caudal 4,6 a 5,8 vezes no CP. Comprimento do focinho contido 3,7 a 4,8, diâmetro orbital 2,8 a 3,7 e distância interorbital 4,6 a 6,0 vezes no CC.

Possui 5 a 7 dentes no pré-maxilar. Linha lateral completa com 35 a 38 escamas, 4 ou $4 \frac{1}{2}$ séries de escamas acima da linha lateral e 3 ou $3 \frac{1}{2}$ abaixo. Nadadeira dorsal com ii +9 raios, peitoral com ii-iii +8 a 10, pélvica com i+7 a 9 , e anal com ii +5 a 7 raios. Apresenta 4 a 6 rastros braquiais superiores e 5 a 7 inferiores. 
Esta espécie não corresponde à descrição de nenhuma congênere e acredita-se ser nova para a Ciência. Seus exemplares iniciam a atividade reprodutiva com $\mathrm{L}_{50}=38,0$ $\mathrm{mm}$ nos machos e $\mathrm{L}_{50}=48,0 \mathrm{~mm}$ nas fêmeas (SUZUKI, 1999). Embora ainda não descrita, acredita-se que a espécie apresente distribuição geográfica restrita à bacia hidrográfica do rio Iguaçu, sendo citada sua ocorrência por Garavello, Pavanelli; Suzuki (1997), Universidade Estadual de Maringá (2002) e Baumgartner, Baumgartner, Pavanelli, Silva, Frana, Oliveira; Michelon (2006).

\section{- Characidium sp. 2 \\ Charutinho}

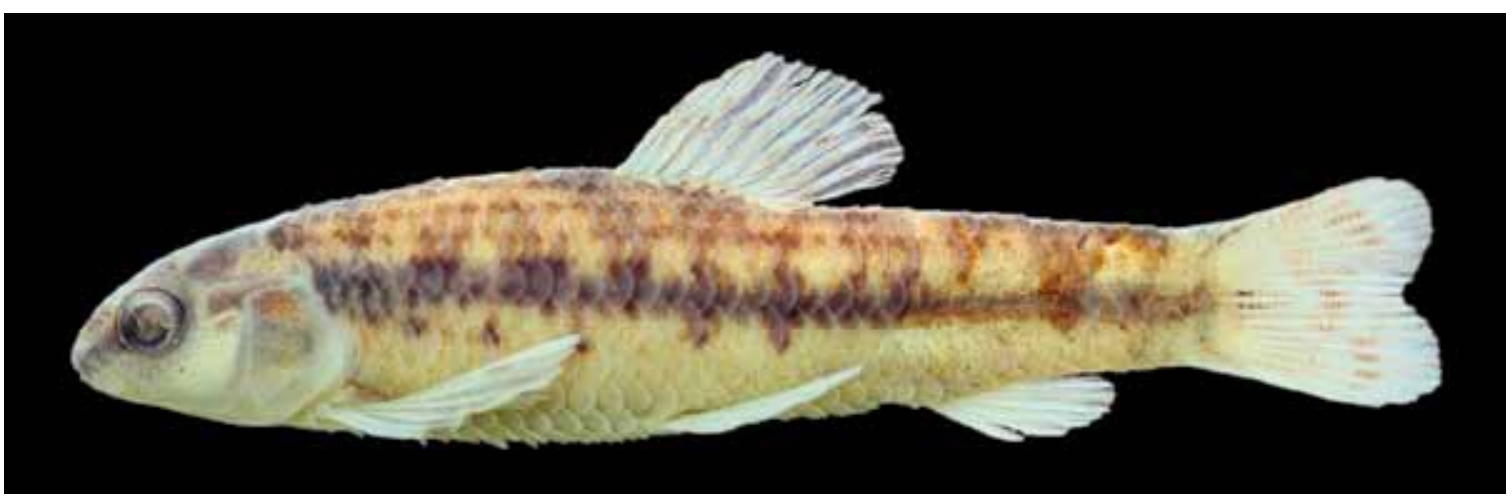

Comprimento padrão $32,9 \mathrm{~mm}$

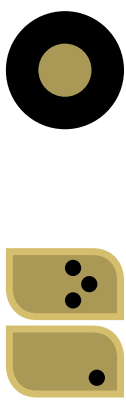

Corpo amarelo-claro, com uma faixa longitudinal marrom-escura bem evidente e com limites irregulares, oito a dez faixas transversais marrom-escuras, largas, às vezes esmaecendo e mais largas dorsalmente. Nadadeiras ímpares com pigmentos escuros sobre os raios, às vezes formando faixas irregulares. Demais nadadeiras hialinas. Possui boca subterminal, istmo não coberto por escamas, corpo relativamente alto e olho pequeno quando comparado ao Characidium sp. 1. Nadadeira adiposa ausente.

Altura do corpo contida 4,4 a 4,8 e do pedúnculo caudal 8,5 a 8,7 vezes no CP; comprimento da cabeça contido 4,1 , pré-dorsal 2,0 e do pedúnculo caudal 5,4 a 6,5 vezes no CP. Comprimento do focinho contido 3,7 a 4,0, diâmetro orbital 3,6 a 3,8 e distância interorbital 4,3 a 5,6 vezes no CC.

Apresenta 6 ou 7 dentes na série interna do pré-maxilar. Linha lateral completa com 35 ou 36 escamas, 5 escamas acima da linha lateral e 21/2 ou 3 abaixo. Nadadeira dorsal com ii-iii+8 a 9 raios, peitoral com iii +8 ou 9 , pélvica com $\mathrm{ii}+6$ ou $\mathrm{i}+7$, e anal com $\mathrm{i}+6$ ou $\mathrm{ii}+5$ raios. Apresenta 5 rastros braquiais superiores e 6 inferiores.

Não há estudos sobre a ecologia desta espécie até o momento, mas sua ocorrência tem sido restrita à bacia do rio Jordão, afluente do rio Iguaçu. O rio Jordão tem apresentado uma ictiofauna peculiar, mesmo quando comparada à do Iguaçu, com elevada taxa de endemismo. 


\section{FAMÍLIA}

\section{Serrasalmidae}

Essa família sempre foi considerada pela maioria dos autores como uma subfamília dentro de Characidae. Aqui é reconhecida como família segundo o trabalho de Mirande (2009). Engloba os pacus e piranhas, ambos ausentes da ictiofauna nativa do rio Iguaçu. Os pacus são famosos pela sua beleza e sabor agradável, o que os torna muito apreciados por aquariofilistas e pescadores profissionais ou amadores. Uma das suas espécies mais importantes na pesca comercial da bacia do Prata tem sido cultivada na região estudada e exemplares podem ter escapado dos tanques, sendo capturados na bacia do Iguaçu. Seus representantes caracterizam-se por apresentar corpo alto e comprimido, duas série de dentes na maxila superior e muitas vezes um par de dentes cônicos atrás da série principal da maxila inferior. Algumas espécies de pacus podem apresentar dimorfismo sexual, alterando o padrão de colorido do corpo e nadadeiras. Embora exemplares de muitos gêneros apresentem um espinho direcionado para frente, adjacente à base do primeiro raio da nadadeira dorsal, a espécie do gênero Piaractus, capturada no rio Iguaçu, não apresenta esta estrutura (JÉGU, 2003).

\section{- Piaractus mesopotamicus (Holmberg, 1887)} Pacu

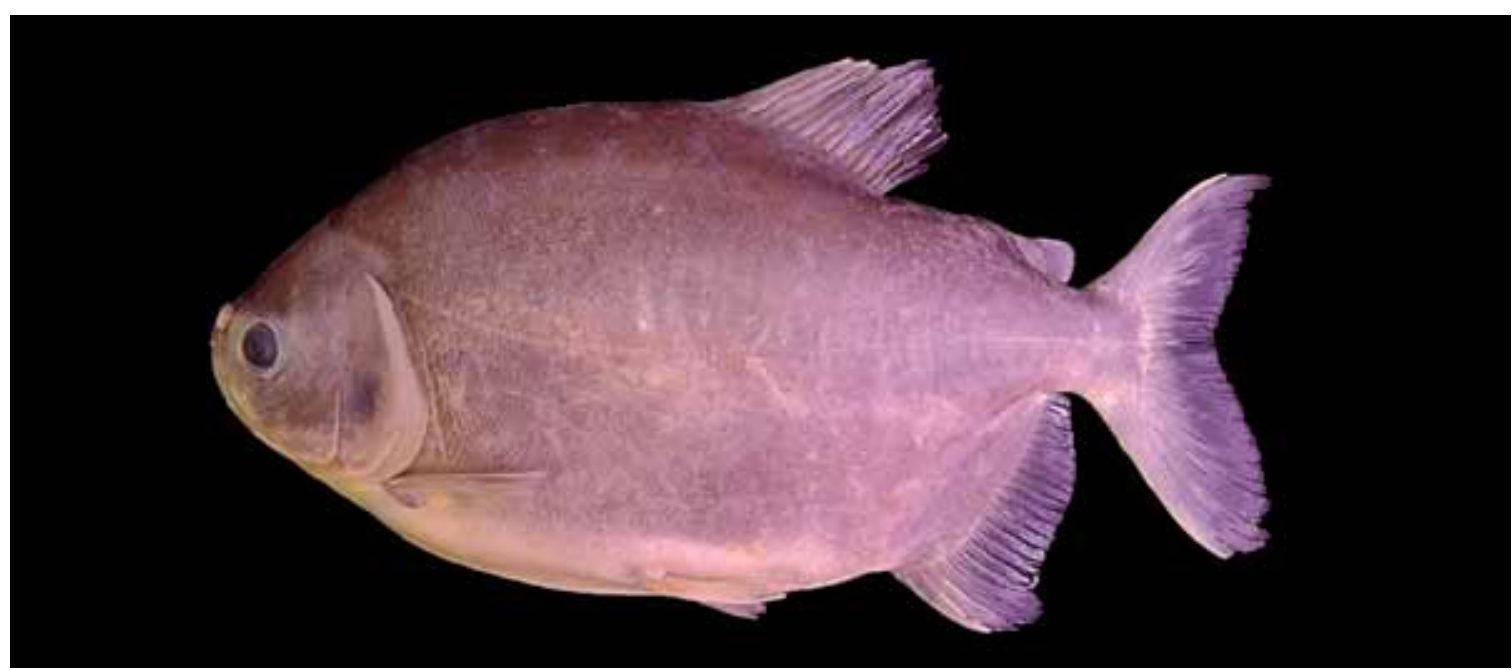

Comprimento padrão 265,0 mm

Corpo acinzentado, mais escuro na região dorsal, clareando em direção à ventral, nadadeiras peitorais e dorsal escuras, pélvica, anal e caudal às vezes alaranjadas em vida, ou esbranquiçadas. Focinho curto, boca terminal e corpo alto.

Altura do corpo contida 1,5 a $2,0^{*}$ e do pedúnculo caudal 8,8 a $8,9^{*}$ vezes no $C P$; comprimento da cabeça contido 2,7 a 4,2*, pré-dorsal 1,6 a $1,7^{*}$ e do pedúnculo caudal 8,8 a $9,4^{*}$ vezes no CP. Comprimento do focinho contido 2,9 a 3,3*, diâmetro orbital 5,2 a $5,5^{*}$ e distância interorbital 1,9 a $2,1^{*}$ vezes no CC.

Possui $2^{*}$ dentes na série interna do pré-maxilar, 6 a $8^{*}$ dentes na série externa e 1 a $2^{*}$ dentes no maxilar, na hemissérie externa do dentário apresenta $6^{*}$ dentes enquanto a interna possui somente $2^{*}$. Linha lateral completa com 107 a $119^{*}$ escamas, 49 a $54^{*}$ séries de escamas acima da linha lateral e 50 a 55* abaixo. Nadadeira dorsal 
com 15 ou $16^{*}$ raios, peitoral com 14 a 17*, pélvica com 8 ou 9*, anal com 23 a $25^{\star}$ e caudal com 19* raios. Possui 52 a $54^{*}$ espinhos simples, seguidos de $7^{\star}$ escamas transformadas em pares de espinhos na quilha ventral.

Esta espécie é considerada onívora, alimentando-se principalmente de insetos e vegetais (HAHN; FUGI; ANDRIAN, 2004). A espécie não apresenta cuidado parental e realiza grandes migrações reprodutivas (SUZUKI; VAZZOLER; MARQUES; LIZAMA; INADA, 2004). É amplamente capturada nas bacias do Paraná e Paraguai (JÉGU; INGENITO, 2007), sendo também capturados exemplares adultos na bacia do rio Iguaçu (UNIVERSIDADE ESTADUAL DE MARINGÁ, 2002), possivelmente decorrentes dos escapes de pisciculturas.

*Graça e Pavanelli (2007)

\section{FAMÍLIA}

\section{Characidae}

Essa família é considerada a maior em número de espécies de peixes neotropicais e a mais complexa entre os Characiformes. O pouco conhecimento desse grupo, seu elevado número de espécies, as semelhanças entre os gêneros e a falta de caracteres sinapomórficos para a definição de subfamílias como monofiléticas, fez com que diversos autores considerassem a maioria dos gêneros de Characidae como incertae sedis (com posição incerta) (LIMA; MALABARBA; BUCKUP; SILVA; VARI; HAROLD; BENINE; OYAKAWA; PAVANELLI; MENEZES; LUCENA; MALABARBA; LUCENA; REIS; LANGEANI; CASATTI; BERTACO; MOREIRA; LUCINDA, 2003). Os membros dessa família possuem ampla distribuição geográfica na região neotropical e seus exemplares podem apresentar de pequeno a grande porte e várias estratégias reprodutivas e alimentares. 


\section{Chave para espécies de Astyanax}

1. Mancha umeral preta, conspícua, ovalada horizontalmente; maxilar sem dentes

A. altiparanae

1'. Mancha umeral escura vertical, arredondada ou irregular, com limites pouco definidos; maxilar com pelo menos um dente 2

2. Margem do terceiro infraorbital próxima à margem do pré-opérculo, sem área nua, ou deixando uma área nua estreita entre estes ossos, contida mais de cinco vezes na altura do terceiro infraorbital.

2'. Margem do terceiro infraorbital distante da margem do pré-opérculo, deixando uma área nua entre estes ossos contida de duas a cinco vezes na altura do terceiro infraorbital

3. Mancha umeral preta mais larga na região superior e estreita na região inferior, dando a aparência de uma vírgula de limites irregulares, seguida de outra mancha posterior, vertical e difusa, às vezes pouco conspícua; nadadeiras avermelhadas quando em vida

A. bifasciatus

3'. Mancha umeral cinza-escura, às vezes difusa, alongada verticalmente, normalmente sem outra mancha posterior evidente; nadadeiras amareladas ou levemente rosadas quando em vida

4. Dentes do pré-maxilar com sete cúspides A. minor

4'. Dentes do pré-maxilar com cinco ou menos cúspides

5. Dentes sinfisianos do pré-maxilar com quatro cúspides, e os da série interna levemente convexos em vista frontal

A. jordanensis

5'. Dentes sinfisianos do pré-maxilar com cinco cúspides, e os da série interna levemente côncavos em vista frontal Astyanaxsp. 2

6. Dentes da série interna do pré-maxilar côncavos em vista frontal 7

6'. Dentes da série interna do pré-maxilar retos ou levemente convexos em vista frontal

7. Mancha umeral verticalmente alongada; olho grande, contido de 2,5 a 3,0 vezes no comprimento da cabeça A. dissimilis

7'. Mancha umeral arredondada e com um estreito prolongamento vertical para baixo; olho pequeno, contido 3,2 a 3,7 vezes no comprimento da cabeça

A. serratus

8. Dentes não sinfisianos do pré-maxilar com apenas três cúspides

A. gymnogenys

8'. Dentes não sinfisianos do pré-maxilar com cinco ou mais cúspides

9. Dente sinfisiano com sete cúspides; corpo baixo, sua altura contida 3,0 vezes ou mais no comprimento padrão Astyanax sp. 1

9'. Dente sinfisiano com cinco cúspides; corpo alto, sua altura contida 3,0 vezes ou menos no comprimento padrão

10. Com 11 ou 12 rastros branquiais superiores

A. gymnodontus

10'. Com nove ou 10 rastros branquiais superiores

A. longirhinus
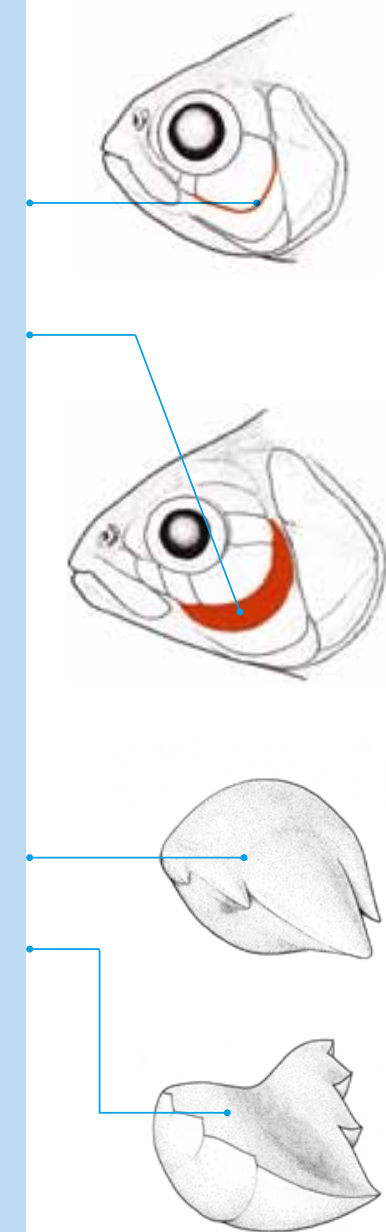
- Astyanax altiparanae Garutti \& Britski, 2000

Tambiú, lambari-relógio

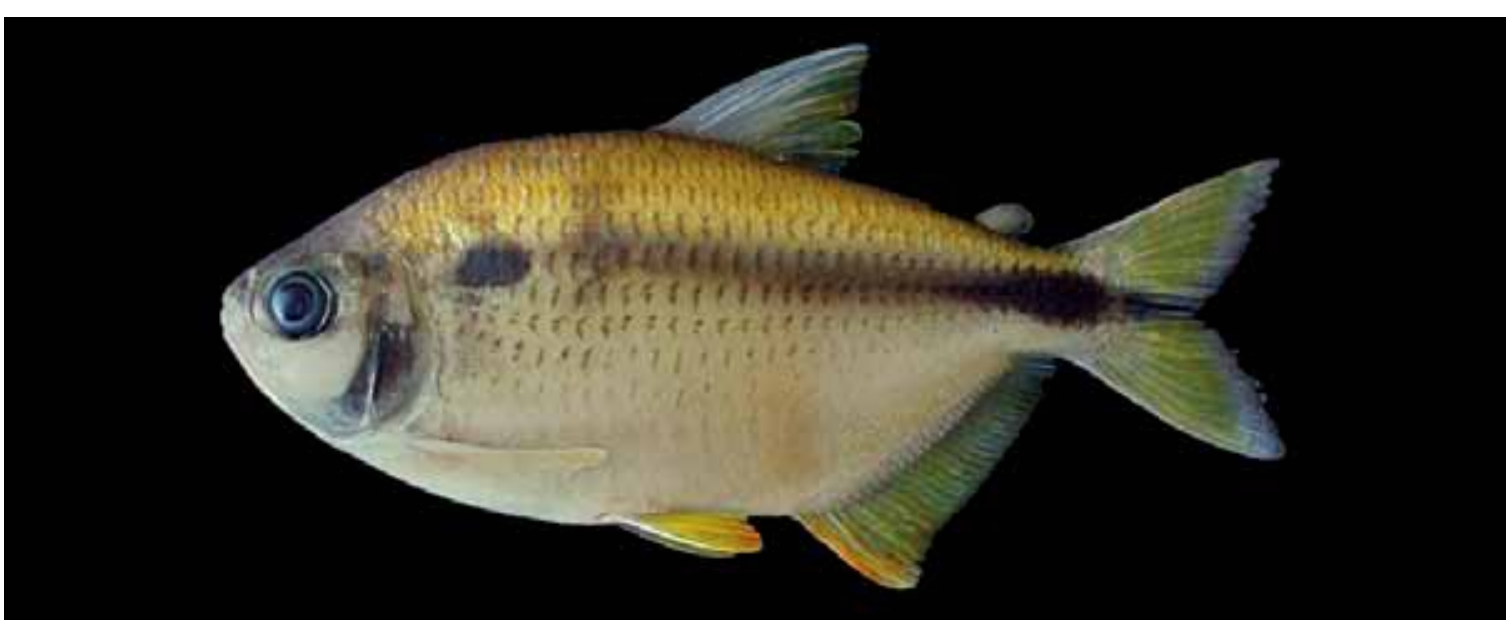

Comprimento padrão 83,0 mm

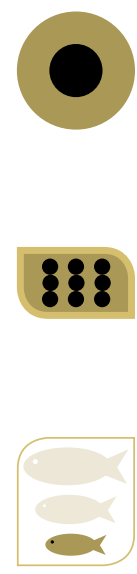

Corpo claro com nadadeiras amareladas; mancha umeral escura horizontalmente ovalada, duas faixas transversais marrons, difusas sobre e após a região umeral, mancha preta horizontalmente alongada no pedúnculo caudal, prolongando-se até a extremidade dos raios caudais medianos. Boca terminal e corpo alto.

Altura do corpo contida 1,9 a $2,6^{*}$ e do pedúnculo caudal 6,9 a 8,6* vezes no CP; comprimento da cabeça contido 3,7 a $4,4^{*}$, pré-dorsal 1,8 a $2,1^{*}$ e do pedúnculo caudal 7,8 a 8,4 vezes no CP. Comprimento do focinho contido 3,2 a 4,1, diâmetro orbital 2,8 a 4,0* e distância interorbital 1,9 a 2,5* vezes no CC.

Possui $5^{*}$ dentes na série interna do pré-maxilar com 5 a $7^{*}$ cúspides, e 4 a $5^{*}$ dentes tri ou pentacuspidados* na série externa. Linha lateral completa com 34 a 38* escamas, sendo 6 a $7^{\star}$ séries de escamas acima da linha lateral e 5 a $7^{*}$ abaixo. Nadadeira dorsal com iii+9* raios, peitoral com i+11 ou $12^{*}$, pélvica com $\mathrm{i}+7$ ou $8 *$ e anal com ii-v+24 a $32 *$ raios.

Espécie considerada herbívora (alimenta-se de vegetais superiores), mas pode também incorporar insetos terrestres (Hymenoptera, Coleoptera e Lepidoptera) e fragmentos de peixes (DELARIVA, 2002) em sua dieta. Seu ritmo alimentar intensifica-se durante o outono na região central do rio (calha), com oscilações aleatórias nos tributários e apresenta também tendência alimentar crepuscular (UNIVERSIDADE ESTADUAL DE MARINGÁ, 2002). Os menores indivíduos em atividade reprodutiva foram registrados com $C P=48,0 \mathrm{~mm}$ nas fêmeas e $C P=45,0 \mathrm{~mm}$ nos machos (UNIVERSIDADE ESTADUAL DO OESTE DO PARANÁ, 2008b, 2009b). Essa espécie é encontrada na bacia do alto Paraná (LIMA; BUCKUP; MENEZES; LUCENA; LUCENA; TOLEDO-PIZA; ZANATA, 2007) e rio Iguaçu (GRAÇA; PAVANELLI, 2002; PRIOLI; PRIOLI; JÚLIO JÚNIOR; PAVANELLI; OLIVEIRA; CARRER; CARRARO; PRIOLI, 2002; BAUMGARTNER; BAUMGARTNER; PAVANELLI; SILVA; FRANA; OLIVEIRA; MICHELON, 2006). 
- Astyanax bifasciatus Garavello \& Sampaio, 2010

Lambari-do-rabo-vermelho

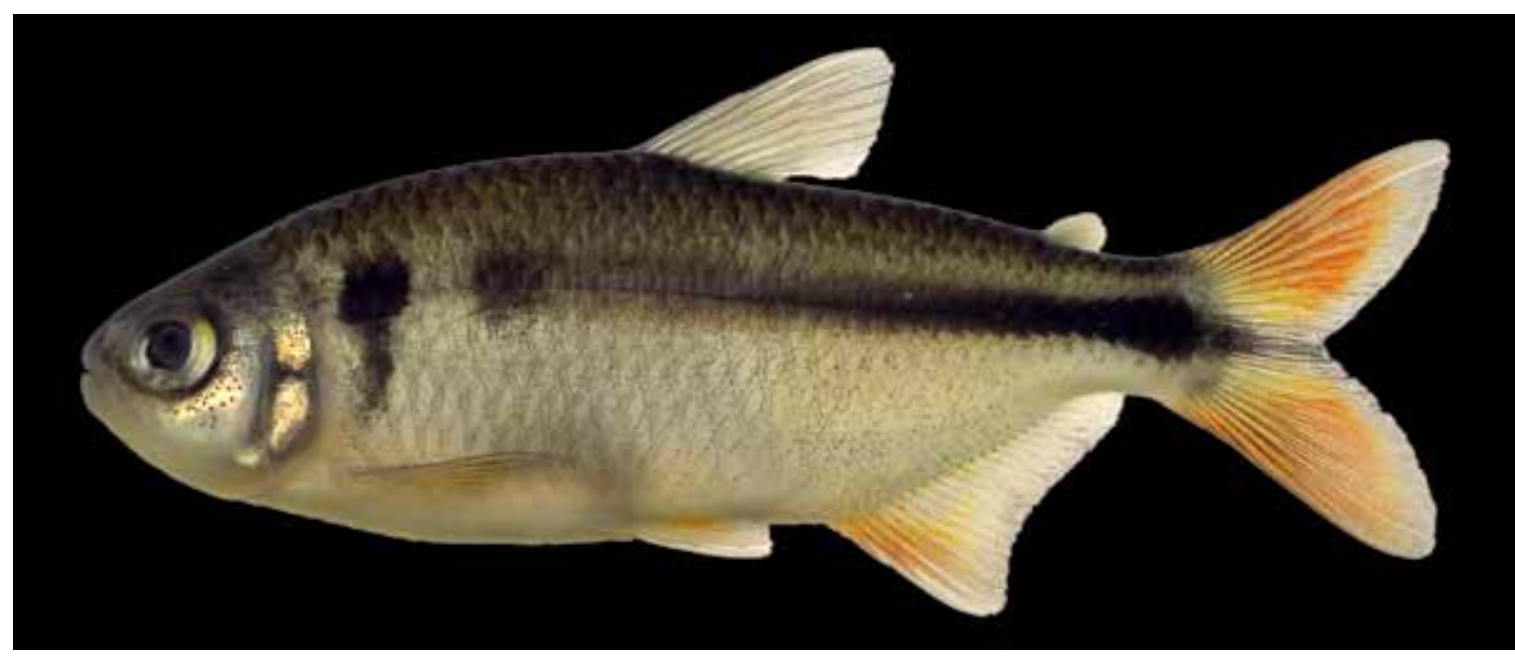

Comprimento padrão 76,4 mm

Corpo claro, nadadeira anal, caudal e dorsal avermelhadas em vida. Mancha umeral preta verticalmente alongada, sendo a porção superior mais larga que a inferior, seguida de uma mancha pós-umeral difusa. Faixa longitudinal escura e larga, mais evidente a partir da segunda mancha umeral, que se prolonga sobre os raios caudais medianos, prateada quando em vida. Espaço entre o $3^{\circ}$ infraorbital e o pré-opérculo ausente ou reduzido.

Altura do corpo contida 2,4 a 3,0 e do pedúnculo caudal 8,1 a 10,1 vezes no CP; comprimento da cabeça contido 3,9 a 4,4, pré-dorsal 1,9 a 2,1 e do pedúnculo caudal 7,9 a 9,9 vezes no CP. Comprimento do focinho contido 3,4 a 4,4, diâmetro orbital 2,4 a 2,7 e distância interorbital 2,9 a 3,3 vezes no CC.

Possui 5 dentes com 7 cúspides na série interna do pré-maxilar, 3 a 5 na série externa e 1 a $2^{*}$ dentes no maxilar. Linha lateral completa com 36 a 39 escamas, 6 a 7 séries de escamas acima da linha lateral e $4 \frac{1}{2}$ a $51 / 2$ abaixo. Nadadeira dorsal com ii +9 raios, peitoral com i+10 a 14, pélvica com i+7 e anal com iii +19 a 24* raios. Apresenta 8 ou 9 rastros braquiais superiores e 11 a 13 inferiores.

Uma das espécies mais abundante no baixo rio Iguaçu, é considerada herbívora (alimenta-se de vegetais superiores), podendo alternativamente alimentar-se de insetos e algas (DELARIVA, 2002; UNIVERSIDADE ESTADUAL DO OESTE DO PARANÁ, 2008b, 2009a, 2009b, 2010). Seu ritmo alimentar intensifica-se durante o outono na caIha central do rio Iguaçu, padrão não evidenciado em seus tributários. Indivíduos dessa espécie iniciam sua atividade reprodutiva com $C P=47,0 \mathrm{~mm}$ nos machos e $C P=53,0$ $\mathrm{mm}$ nas fêmeas, e apesar de reproduzirem-se durante todo o ano, a maior intensidade reprodutiva ocorre na primavera e inicio do verão (SUZUKI, 1999). Sua distribuição geográfica é aparentemente restrita à bacia hidrográfica do rio Iguaçu. Antes de sua recente descrição, esta espécie era conhecida na bacia do rio Iguaçu como Astyanax sp. B, a partir de Sampaio (1988). 
- Astyanax dissimilis Garavello \& Sampaio, 2010

Lambari

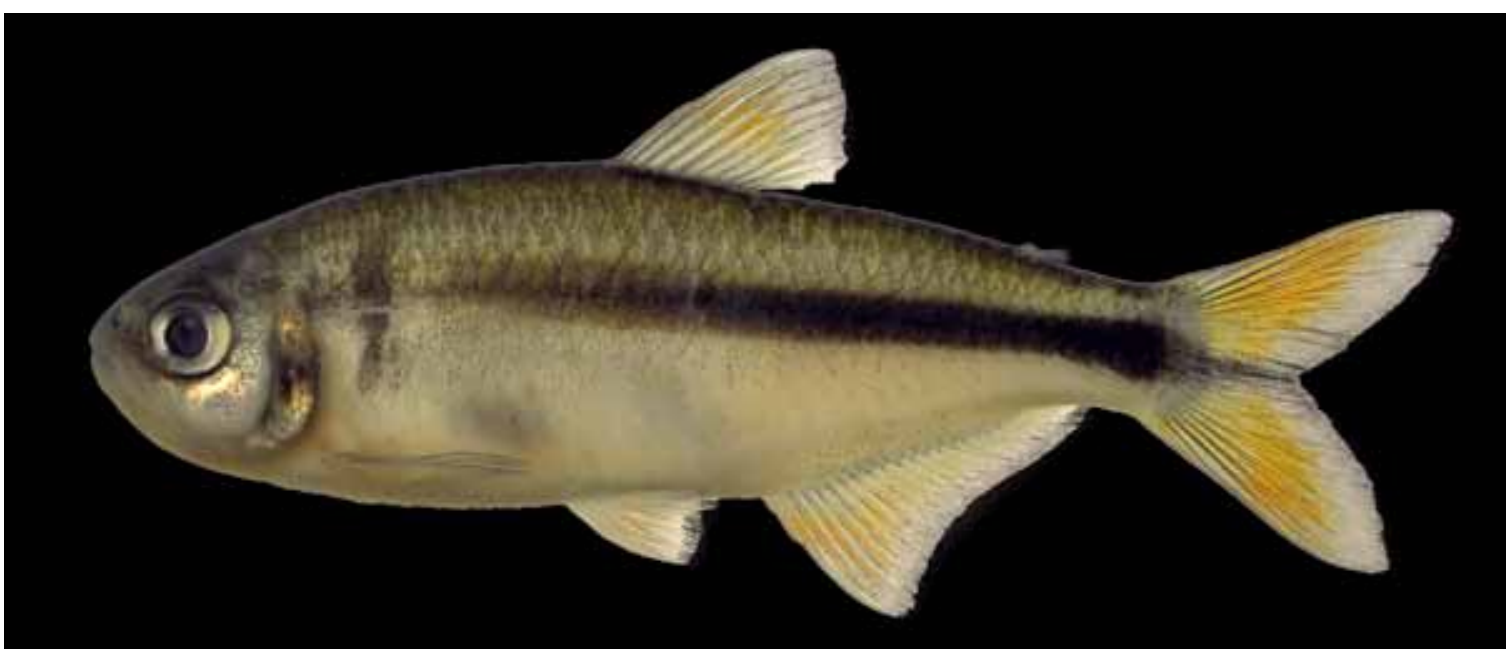

Comprimento padrão $74,8 \mathrm{~mm}$

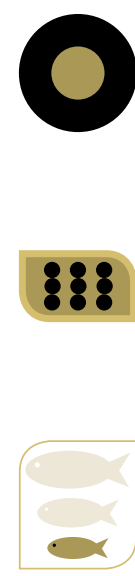

Corpo claro, com mancha umeral preta, verticalmente alongada, às vezes difusa, seguida de uma mancha pós-umeral escura, difusa e às vezes inconspícua. Faixa longitudinal escura e larga, mais evidente a partir da segunda mancha umeral, e prateada quando em vida. Margem do $3^{\circ}$ infraorbital separada do pré-opérculo por uma ampla área de pele (área nua) e boca terminal.

Altura do corpo contida 2,5 a 3,0 e do pedúnculo caudal 8,2 a 9,6 vezes no CP; comprimento da cabeça contido 3,7 a 4,1, pré-dorsal 1,8 a 2,0 e do pedúnculo caudal 7,4 a 8,5 vezes no CP. Comprimento do focinho contido 3,7 a 4,6, diâmetro orbital 2,5 a 3,0 e distância interorbital 2,7 a 3,2 vezes no CC.

Possui 4 ou 5 dentes (geralmente 5) na série interna do pré-maxilar, com 7 cúspides (raramente 5), que, em vista ventral, formam um arco côncavo na superfície frontal, conferindo uma concavidade a cada dente. Série externa com 3 a 5 dentes e maxilar com 1 a 3*. Linha lateral completa com 35 a 37 escamas, 6 a 71/2 séries de escamas acima da linha lateral e $4 \frac{1}{2}$ a 6 abaixo. Nadadeira dorsal com ii +8 ou 9 raios, peitoral com i+11 a 13, pélvica com i+7 a 9 e anal com iii+16 a 21* raios. Apresenta 8 ou 9 rastros branquiais superiores e 10 a 12 inferiores.

Alimenta-se essencialmente de vegetais superiores (espécie herbívora), podendo utilizar insetos alternativamente (HAHN; FUGI; ALMEIDA; RUSSO; LOUREIRO, 1997), sendo sua dieta influenciada por represamentos (DELARIVA, 2002). Essa espécie apresenta indivíduos em reprodução durante todo o ano (UNIVERSIDADE ESTADUAL DE MARINGÁ, 2002), e os menores indivíduos em reprodução foram registrados com $C P=54,0 \mathrm{~mm}$ nos machos e CP=66,0 mm nas fêmeas (SUZUKI; AGOSTINHO, 1997). Sua distribuição geográfica é aparentemente restrita à bacia hidrográfica do rio Iguaçu. Antes de sua recente descrição, esta espécie era conhecida na bacia do rio Iguaçu como Astyanax sp. E, a partir de Sampaio (1988).

*Garavello e Sampaio (2010) 


\section{- Astyanax gymnodontus (Eigenmann, 1911) Lambarizão}

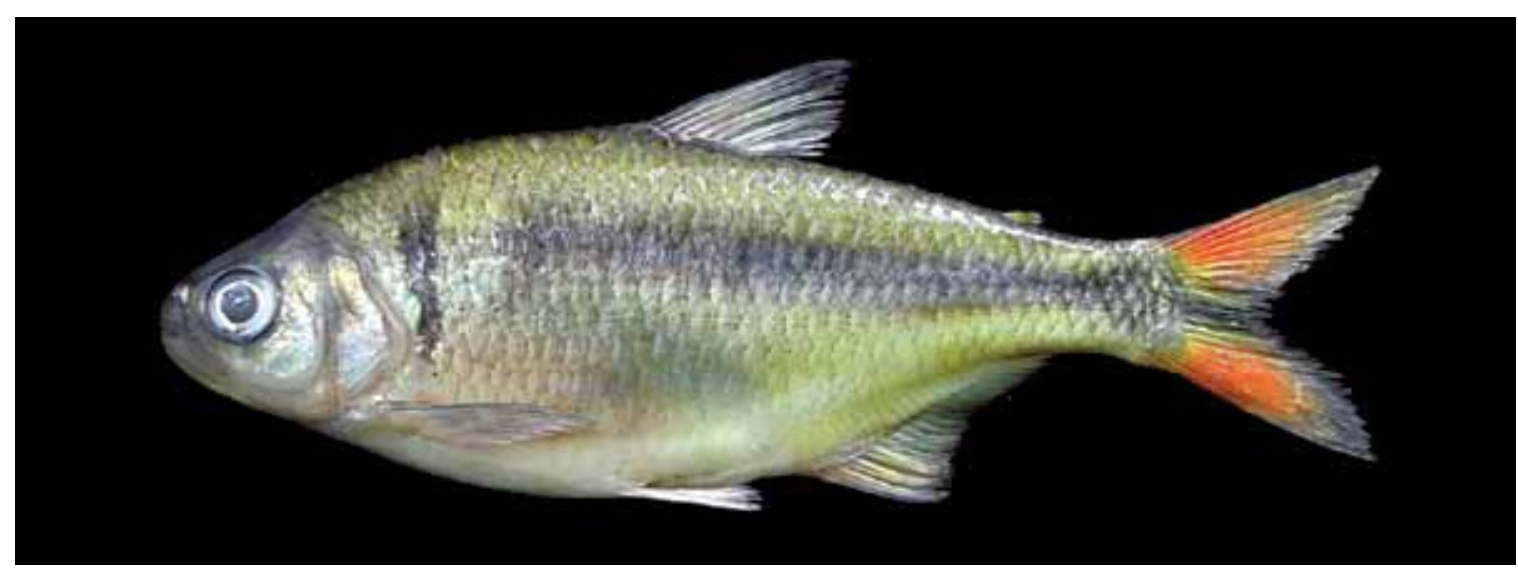

Comprimento padrão 115,0 mm

Corpo claro, sendo o dorso e a cabeça escurecidos. Mancha umeral preta e verticalmente alongada, com limites pouco definidos, seguida por outra muito difusa, normalmente pouco conspícua. Faixa longitudinal cinza-escura, larga e difusa acima da linha lateral, mais evidente a partir da segunda mancha umeral, que se prolonga sobre os raios caudais medianos. Pode ou não apresentar lábios ou dentes na série externa do pré-maxilar, desde lábio completamente ausente a bem desenvolvido e números variáveis de dentes na série externa do pré-maxilar, posicionados de maneira irregular, quando presentes. Pode apresentar divergências mesmo entre os lados da boca do mesmo indivíduo. $\mathrm{O} 3^{\circ}$ infraorbital e o pré-opérculo são separados por uma ampla área de pele (área nua).

Altura do corpo contida 2,4 a $2,9^{*}$ e do pedúnculo caudal 7,6 a $8,8^{*}$ vezes no $C P$; comprimento da cabeça contido 3,6 a 4,2*, pré-dorsal 1,8 a $2,1^{*}$ e do pedúnculo caudal 9,9 a $12^{*}$ vezes no CP. Comprimento do focinho contido 3,2 a 4,5*, diâmetro orbital 2,4 a 3,4* e distância interorbital 2,7 a 3,5* vezes no CC.

Possui 5 a $7^{*}$ dentes pentacuspidados na série interna ou única do pré-maxilar, 0 a 4 na série externa, e maxilar com 1 a $4^{*}$ dentes. Linha lateral completa com 37 a $41^{*}$ escamas, 6 a $8^{*}$ séries de escamas acima da linha lateral e 5 a $6^{*}$ abaixo. Nadadeira dorsal com ii-iii +8 a $10^{*}$ raios, peitoral com i+11 a $14^{*}$, pélvica com $i+7$ ou $8^{*}$ e anal com iii +19 a $22^{\star}$ raios. Apresenta 7 a 9 rastros branquiais superiores e 11 ou 12 inferiores.

Alimenta-se essencialmente de insetos, podendo utilizar alternativamente vegetais superiores (HAHN; FUGI; ALMEIDA; RUSSO; LOUREIRO, 1997; UNIVERSIDADE ESTADUAL DO OESTE DO PARANÁ, 2008b, 2009a, 2009b). Segundo estes autores, os menores indivíduos em atividade reprodutiva foram registrados com $\mathrm{CP}=55,0 \mathrm{~mm}$ nas fêmeas e $\mathrm{CP}=58,0 \mathrm{~mm}$ nos machos. Sua distribuição geográfica é aparentemente restrita à bacia do rio Iguaçu. A partir de Sampaio (1988), exemplares desta espécie com lábios desenvolvidos e dentes na série externa do pré-maxilar eram identificados na bacia do rio Iguaçu como Astyanax sp F. e Psalidodon gymnodontus Eigenmann, 1911, do gênero monoespecífico e endêmico, caracterizada por apresentar uma única série de dentes no pré-maxilar e lábios completamente ausentes, era igualmente reconhecida na bacia do rio Iguaçu. Entretanto, a presença de muitos exemplares que apresentavam condições intermediárias de desenvolvimento dos lábios e dos dentes na 
série externa do pré-maxilar (Psalidodon sp.), entre Astyanax sp. F e $P$. gymnodontus, motivaram a realização de um estudo conduzido por Pavanelli e Oliveira (2009), que concluíram que os exemplares inicialmente atribuídos a dois gêneros diferentes eram na verdade pertencentes a uma única espécie de lambari, com ampla variação dos caracteres bucais supramencionados.

*Pavanelli e Oliveira (2009)

\section{- Astyanax gymnogenys Eigenmann, 1911 \\ Lambari}

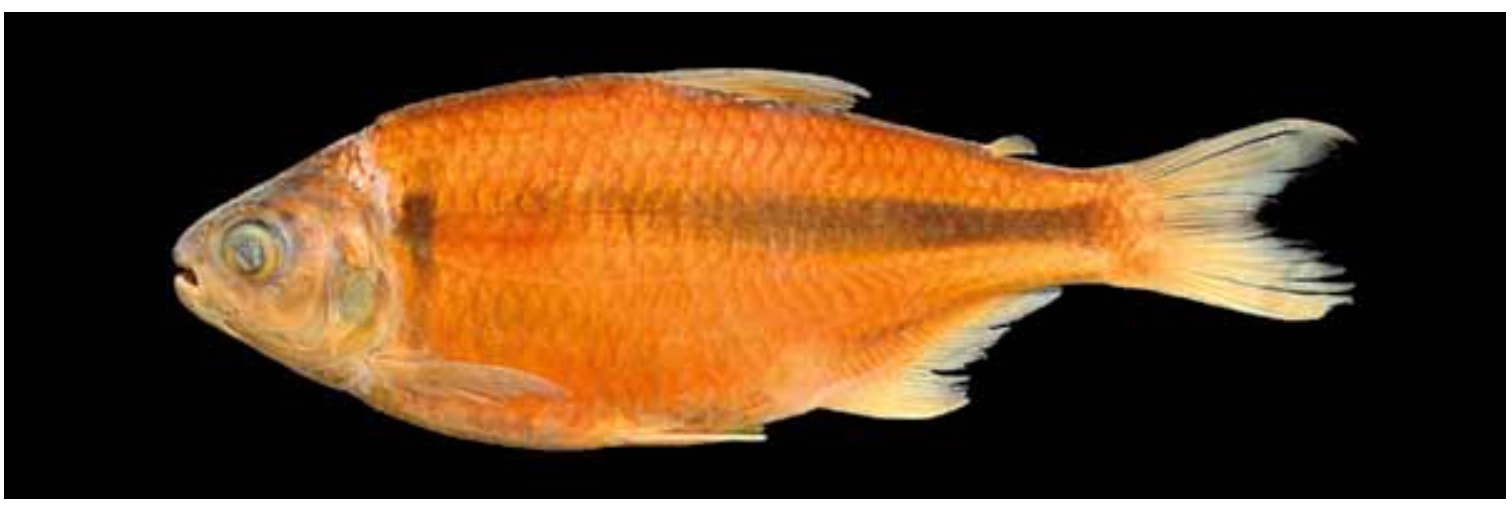

Comprimento padrão 113,8 mm

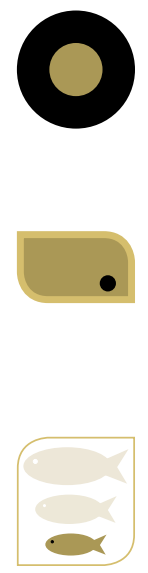

Corpo castanho, mais claro ventralmente. Mancha umeral preta, verticalmente alongada, seguida de uma mancha pós-umeral escura, difusa e às vezes inconspícua. Faixa longitudinal escura e larga, mais evidente a partir da segunda mancha umeral, que pode prolongar-se sobre os raios caudais medianos, e prateada quando em vida. Margem do $3^{\circ}$ infraorbital distante do pré-opérculo, deixando uma ampla área coberta por pele (área nua). Maxilar curto em relação ao pré-maxilar, olho pequeno, boca terminal e corpo alto.

Altura do corpo contida 2,4 a 2,7 e do pedúnculo caudal 8,1 a 9,2 vezes no CP; comprimento da cabeça contido 4,1 a 4,4, pré-dorsal 1,8 a 2,0 e do pedúnculo caudal 8,2 a 9,8 vezes no CP. Comprimento do focinho contido 3,7 a 4,2, diâmetro orbital 2,8 a 3,2 e distância interorbital 2,6 a 3,2 vezes no CC.

Possui $5^{*}$ dentes com $3^{*}$ cúspides na série interna do pré-maxilar, 2 a 4 * na série externa e maxilar com 1 a $3^{*}$ dentes. Linha lateral completa com 38 a 41 escamas, 6 a 7 séries de escamas acima da linha lateral e 5 a 51/2 abaixo. Nadadeira dorsal com ii +8 ou $9 *$ raios, peitoral com $\mathrm{i}+12$ ou $13^{*}$, pélvica com $\mathrm{i}+7$ ou $8 *$ e anal com iii +18 a 20 * raios. Apresenta $6 *$ rastros branquiais superiores e 10 ou $11^{*}$ inferiores.

No reservatório de Segredo, essa espécie é considerada malacófaga, alimentando-se principalmente de gastrópodos (HAHN; FUGI; ALMEIDA; RUSSO; LOUREIRO, 1997). O período de reprodução estende-se de outubro a janeiro, mais intensamente entre novembro e janeiro (SUZUKI; AGOSTINHO, 1997). Essa espécie é considerada como vulnerável à extinção por Abilhoa e Duboc (2004). Sua distribuição geográfica é aparentemente restrita à bacia hidrográfica do rio Iguaçu. Sampaio (1988) chamou exemplares desta espécie erroneamente de Astyanax sp. A em seu trabalho.

*Garavello e Sampaio (2010) 
- Astyanax jordanensis Alcaraz, Pavanelli \& Bertaco, 2009 Lambari

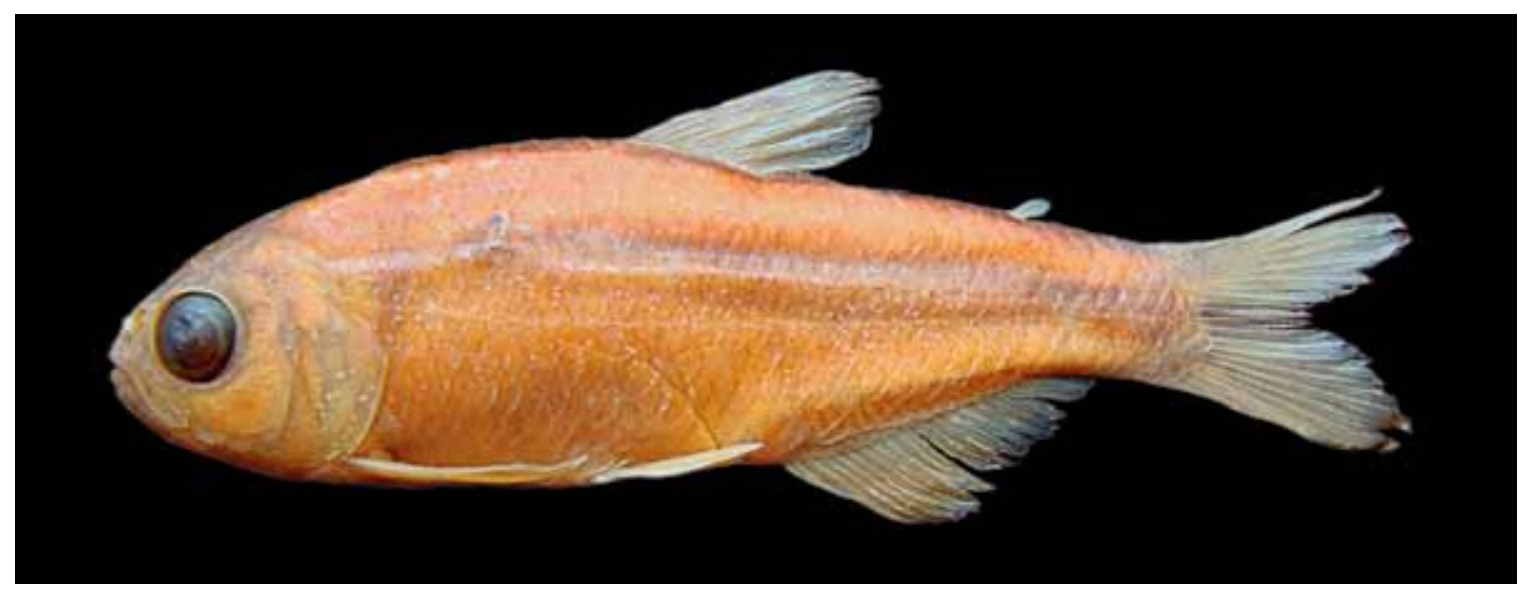

Comprimento padrão 47,7 mm

Corpo marrom-claro, mais escurecido nas porções dorsais da cabeça e do tronco, clareando em direção à região ventral. Faixa longitudinal marrom-escura na lateral do corpo, larga, mas pouco conspícua, que pode prolongar-se sobre os raios caudais medianos. Mancha umeral cinza-escura, às vezes pouco evidente, verticalmente alongada. Boca terminal e espaço entre o $3^{\circ}$ infraorbital e o pré-opérculo ausente ou reduzido.

Altura do corpo contida 2,8 a $3,6^{*}$ e do pedúnculo caudal 7,3 a 9,2* vezes no $C P$; comprimento da cabeça contido 3,2 a 3,9*, pré-dorsal 1,7 a 2,0* e do pedúnculo caudal 6,0 a $7,3^{*}$ vezes no CP. Comprimento do focinho 3,4 a 4,0* diâmetro orbital 3,4 a $4,4^{*}$ e distância interorbital 2,8 a 3,3* vezes no CC.

Possui $5^{*}$ dentes com 4 a $7^{*}$ cúspides na série interna do pré-maxilar, 3 a $5^{\star}$ na série externa e 1 ou $2^{*}$ dentes no maxilar. Linha lateral completa com 35 a $38^{*}$ escamas, 5 a $7^{*}$ séries de escamas acima da linha lateral e $5^{\star}$ abaixo. Nadadeira dorsal com $i-i i+9^{*}$ raios, peitoral com $i+9$ a $12^{*}$, pélvica com $i+6$ ou $7^{*}$ e anal com iii-v+14 a $17^{*}$ raios. Apresenta $6^{*}$ rastros branquiais superiores e 10 ou $11^{*}$ inferiores.

A ocorrência dessa espécie é aparentemente limitada aos rios Jacu e das Torres, bacia do rio Jordão (ALCARAZ; PAVANELLI; BERTACO, 2009), que é um afluente do rio Iguaçu que possui um certo grau de endemismo, mesmo quando comparado ao restante da bacia do Iguaçu. Atualmente o rio Jordão possui uma usina para geração de energia elétrica em sua foz, cujo reservatório submergiu uma queda d'água que pode ter atuado como barreira efetiva para a livre dispersão de espécies de peixes entre o rio Jordão e o rio Iguaçu, justificando este endemismo.

*Alcaraz, Pavanelli e Bertaco (2009) 


\section{- Astyanax longirhinus Garavello \& Sampaio, 2010 Lambari}

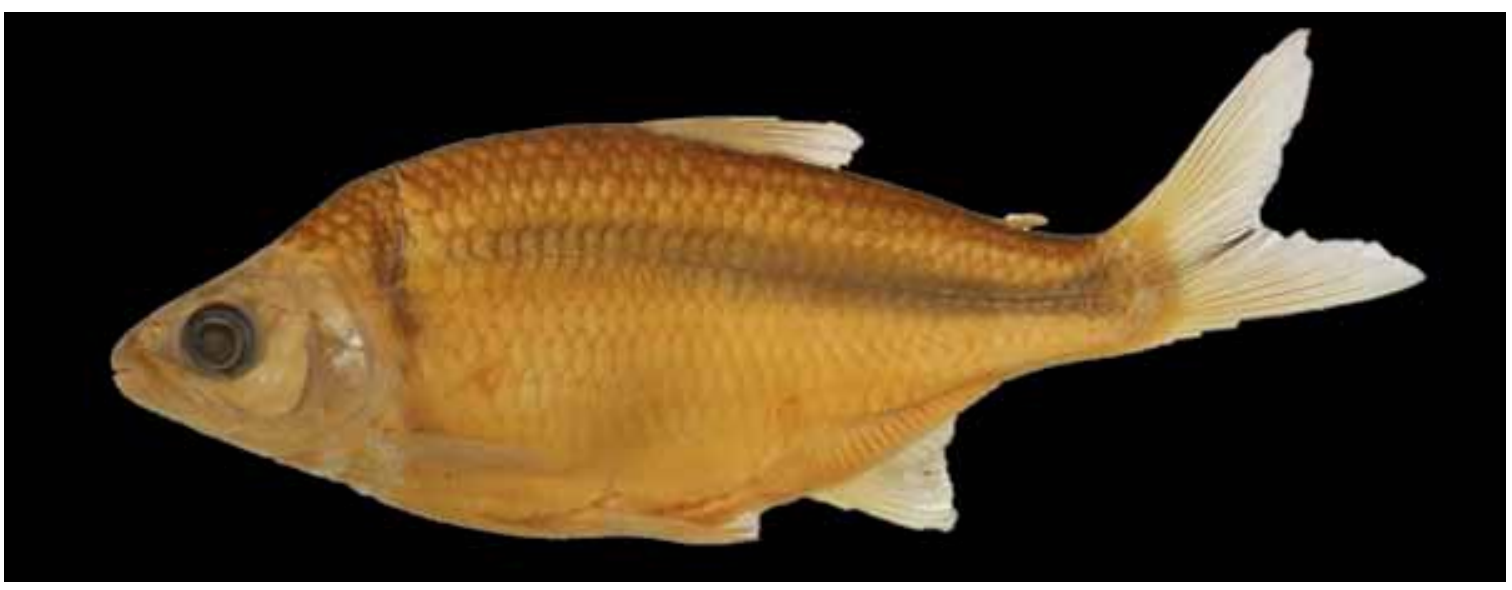

Comprimento padrão 105,0 mm

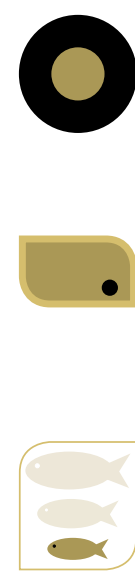

Corpo claro, escurecendo em direção ao dorso. Mancha umeral cinza-escura, prolongada verticalmente. Faixa longitudinal escura e larga, mais evidente após a região da mancha umeral, que pode prolongar-se sobre os raios caudais medianos, prateada quando em vida. Boca terminal. O $3^{\circ}$ infraorbital e o pré-opérculo são separados por uma ampla área de pele (área nua).

Altura do corpo contida 2,5 a 3,1* e do pedúnculo caudal 8,1 a 9,6 vezes no CP; comprimento da cabeça 3,8 a 3,9*, pré-dorsal 1,9 a 2,2* e do pedúnculo caudal 7,8 a 8,8 vezes no $C P$. Comprimento do focinho contido 3,3 a 4,3, diâmetro orbital 3,7 a 5,1* e distância interorbital 2,7 a 4,0* vezes no CC.

Possui 5 dentes com 3 a 5 cúspides na série interna do pré-maxilar, 2 a 4 na série externa e maxilar com 1 a 3 dentes. Linha lateral completa com 41 a 44 * escamas, 61/2 a 7 séries de escamas acima da linha lateral e 5 a 6 abaixo. Nadadeira dorsal com ii+9* raios, peitoral com $\mathrm{i}+11^{*}$, pélvica com $\mathrm{i}+7^{*}$ e anal com ii $-\mathrm{iii}+18$ a $20^{*}$ raios. Apresenta $7 *$ rastros branquiais superiores e $9 *$ inferiores.

Essa espécie alimenta-se exclusivamente de invertebrados (malacófaga) (HAHN; FUGI; ALMEIDA; RUSSO; LOUREIRO, 1997). Sua distribuição geográfica é aparentemente restrita à bacia hidrográfica do rio Iguaçu. Antes de sua recente descrição, esta espécie era conhecida na bacia do rio Iguaçu como Astyanax sp. G, a partir de Sampaio (1988).

*Garavello e Sampaio (2010) 
- Astyanax minor Garavello \& Sampaio, 2010

Lambari-do-rabo-amarelo

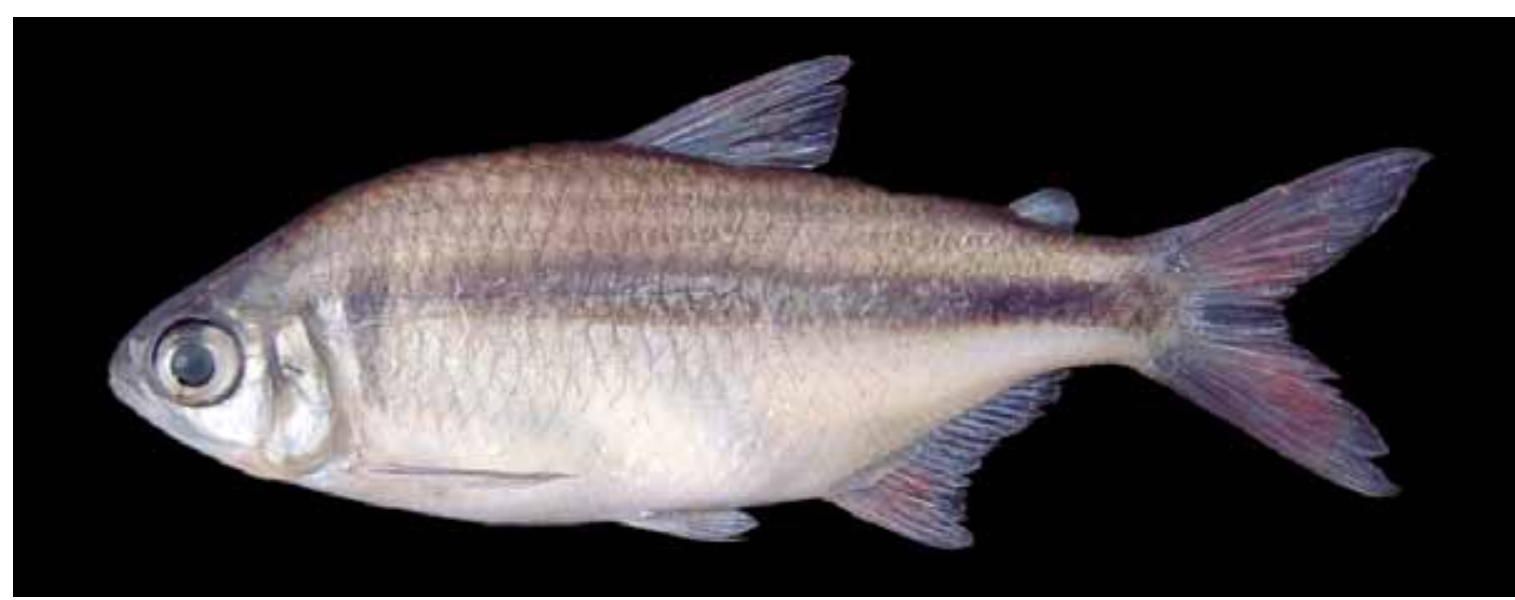

Comprimento padrão $89,0 \mathrm{~mm}$

Corpo claro, mancha umeral cinza-escura, verticalmente alongada, às vezes difusa. Nadadeiras ímpares amareladas ou alaranjadas em vida. Faixa longitudinal escura e larga, mais evidente após a região da mancha umeral, que se prolonga sobre os raios caudais medianos, prateada quando em vida. Espaço entre o $3^{\circ}$ infraorbital e o pré-opérculo ausente ou reduzido. Boca terminal.

Altura do corpo contida 2,2 a 2,8* e do pedúnculo caudal 7,5 a 9,0 vezes no CP; comprimento da cabeça contido 3,9 a $4,5^{*}$, pré-dorsal 1,8 a $2,2^{*}$ e do pedúnculo caudal 7,9 a 10,0 vezes no CP. Comprimento do focinho contido 3,6 a 4,5*, diâmetro orbital 2,4 a 3,2* e distância interorbital 2,5 a 3,2* vezes no CC.

Possui 5 dentes com 7 cúspides na série interna do pré-maxilar, 3 a 6 na série externa e 1 ou 2 dentes no maxilar. Linha lateral completa com 36 a 39* escamas, 51/2 a $6 \frac{1 / 2}{2}$ séries de escamas acima e $4 \frac{1}{2}$ a 6 abaixo da linha lateral. Nadadeira dorsal com $\mathrm{ii}+8$ a $10^{*}$ raios, peitoral com $\mathrm{i}+10$ a $14^{*}$, pélvica com i+7 ou $8^{*}$ e anal com iii +16 a $23^{*}$ raios. Apresenta 9 a $12^{\star}$ rastros branquiais superiores e 13 a 16* inferiores.

Essa espécie, muito abundante em reservatórios estabilizados e amplamente distribuída no baixo rio Iguaçu, caracteriza-se pela onivoria que Ihe confere grande plasticidade alimentar, porém, em alguns locais seu hábito é detritívoro. Seu ritmo alimentar intensifica-se durante o outono na calha principal do rio Iguaçu, não apresentando padrões de sazonalidade para os tributários. A reprodução pode ocorrer durante o ano todo, com maior intensidade entre novembro e março (UNIVERSIDADE ESTADUAL DO OESTE DO PARANÁ, 2008b, 2009a, 2009b, 2010). Segundo estes autores, os menores indivíduos em atividade reprodutiva foram registrados com $C P=56,0 \mathrm{~mm}$ nas fêmeas e $\mathrm{CP}=48,0 \mathrm{~mm}$ nos machos. Sua distribuição geográfica é aparentemente restrita à bacia hidrográfica do rio Iguaçu. Antes de sua recente descrição, esta espécie era conhecida na bacia do rio Iguaçu como Astyanax sp. C, a partir de Sampaio (1988).

*Garavello e Sampaio (2010) 
- Astyanax serratus Garavello \& Sampaio, 2010

Lambari

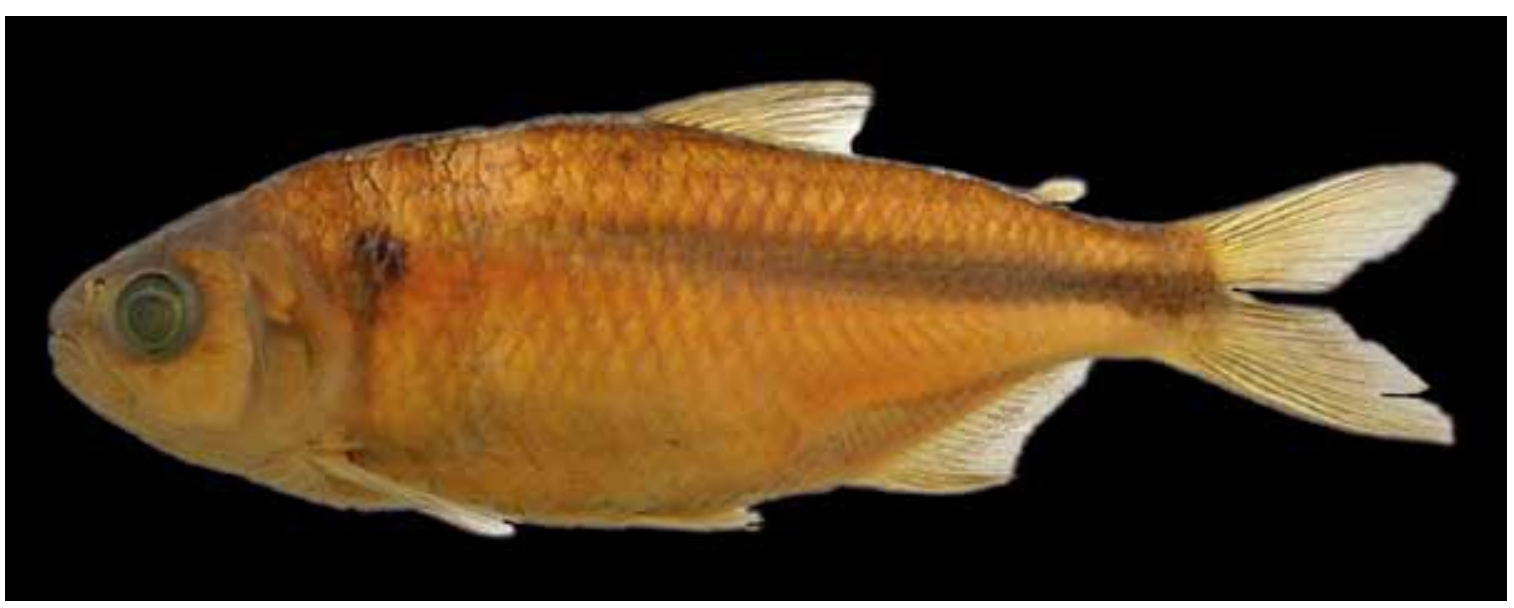

Comprimento padrão 100,2 mm

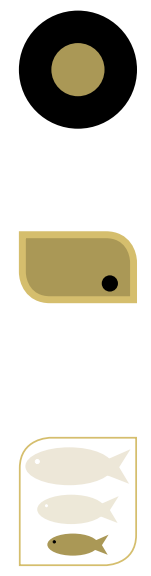

Corpo castanho-claro, mais claro ventralmente, escurecendo em direção ao dorso. Mancha umeral preta, arredondada e com estreito prolongamento vertical para baixo, seguida de uma mancha pós-umeral escura, difusa e às vezes inconspícua. Faixa longitudinal escura e larga, mais evidente a partir da segunda mancha umeral, que se prolonga sobre os raios caudais medianos, prateada quando em vida. Mandíbula robusta, margem do $3^{\circ}$ infraorbital separada do pré-opérculo por uma ampla área de pele (área nua) e boca terminal.

Altura do corpo contida 2,6 a 3,1 e do pedúnculo caudal 7,8 a 9,0 vezes no CP; comprimento da cabeça contido 3,4 a 3,9, pré-dorsal 1,8 a 2,1 e do pedúnculo caudal 7,4 a 8,5 vezes no CP. Comprimento do focinho contido 3,6 a 4,4, diâmetro orbital 3,2 a 3,7 e distância interorbital 2,3 a 2,9 vezes no CC.

Possui 5 dentes com 5 a 7 cúspides na série interna do pré-maxilar, que, em vista ventral, formam um arco côncavo na superfície frontal. Série externa com 4 ou 5 dentes e 1 a 4 dentes no maxilar. Linha lateral completa com 35 a 38 escamas, $61 / 2$ a 7 séries de escamas acima e 51/2 a 6 abaixo da linha lateral. Nadadeira dorsal com ii +8 ou 9 * raios, peitoral com i+11 a $13^{*}$, pélvica com i+6 a $8^{*}$ e anal com iii +16 a $20^{*}$ raios. Apresenta 8 a 9 rastros branquiais superiores e 10 a 12 inferiores.

Sua distribuição geográfica é aparentemente restrita à bacia hidrográfica do rio Iguaçu. Antes de sua recente descrição, esta espécie era conhecida na bacia do rio Iguaçu como Astyanax sp. D, a partir de Sampaio (1988).

*Garavello e Sampaio (2010) 
- Astyanax sp. 1

Lambari

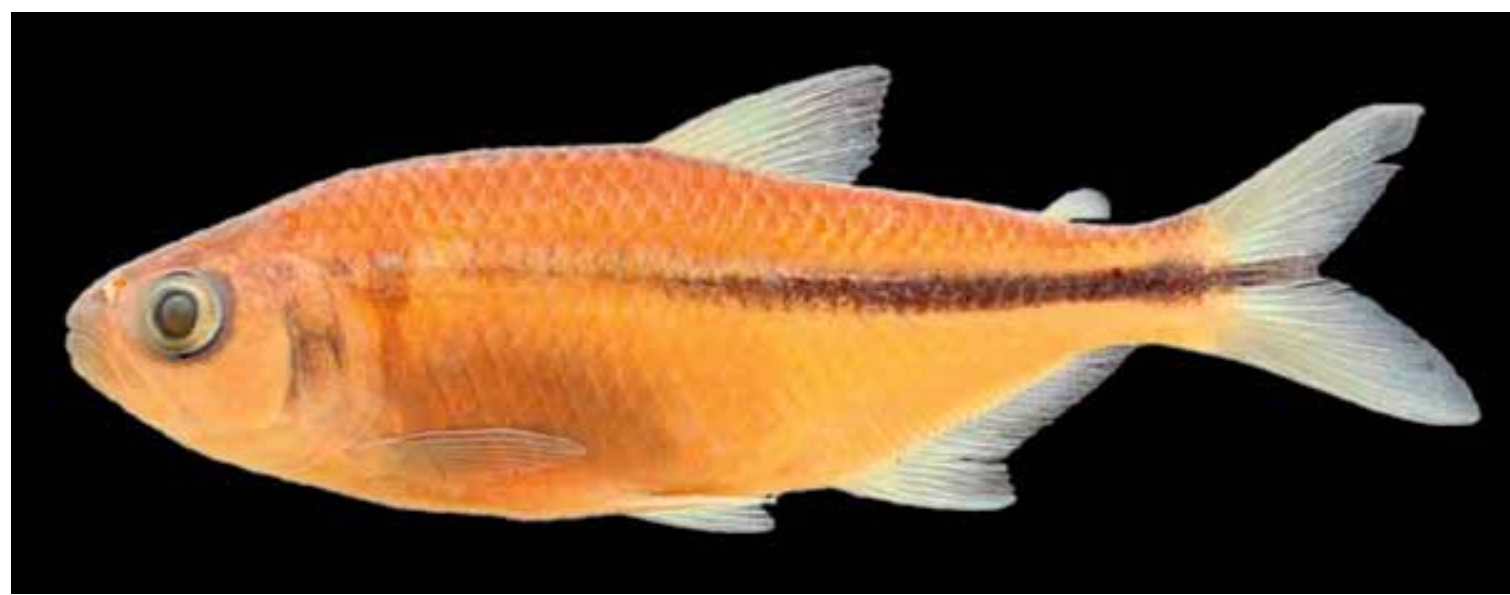

Comprimento padrão 78,1mm

Corpo castanho-claro, mais claro ventralmente, escurecendo em direção ao dorso. Mancha umeral preta, verticalmente alongada e com estreito prolongamento vertical para baixo. Faixa longitudinal escura e larga, mais evidente após a região da mancha umeral, que se prolonga sobre os raios caudais medianos, prateada quando em vida. Margem do $3^{\circ}$ infraorbital distante do pré-opérculo, deixando uma ampla área coberta por pele (área nua) e boca terminal.

Altura do corpo contida 3,0 a 3,5 e do pedúnculo caudal 9,5 a 11,1 vezes no $C P$; comprimento da cabeça 3,5 a 3,9, pré-dorsal 1,9 a 2,0 e do pedúnculo caudal 7,4 a 8,8 vezes no CP. Comprimento do focinho contido 3,6 a 4,1, diâmetro orbital 2,6 a 3,1 e distância interorbital 3,2 a 3,7 vezes no CC.

Possui 4 ou 5 dentes com 7 cúspides na série interna do pré-maxilar 3 ou 4 na série externa e maxilar com 1 ou 2 dentes. Linha lateral completa com 36 a 39 escamas, $61 / 2$ a $7 \frac{1}{2}$ séries de escamas acima da linha lateral e 5 a $61 / 2$ abaixo. Nadadeira dorsal com ii +9 raios, peitoral com i+11 a 14, pélvica com i+ 7 ou 8 e anal com ii +21 a 23 raios. Apresenta 8 a 10 rastros branquiais superiores e 11 a 13 inferiores.

Capturada apenas no rio Candói, afluente do rio Jordão, em coletas realizadas pelo Nupélia, acredita-se que a espécie apresente sua distribuição geográfica restrita à bacia do rio Jordão, afluente do rio Iguaçu, a exemplo de outras espécies que caracterizam a ictiofauna deste rio como endêmica, mesmo em relação ao restante da bacia do Iguaçu. 
- Astyanax sp. 2

Lambari

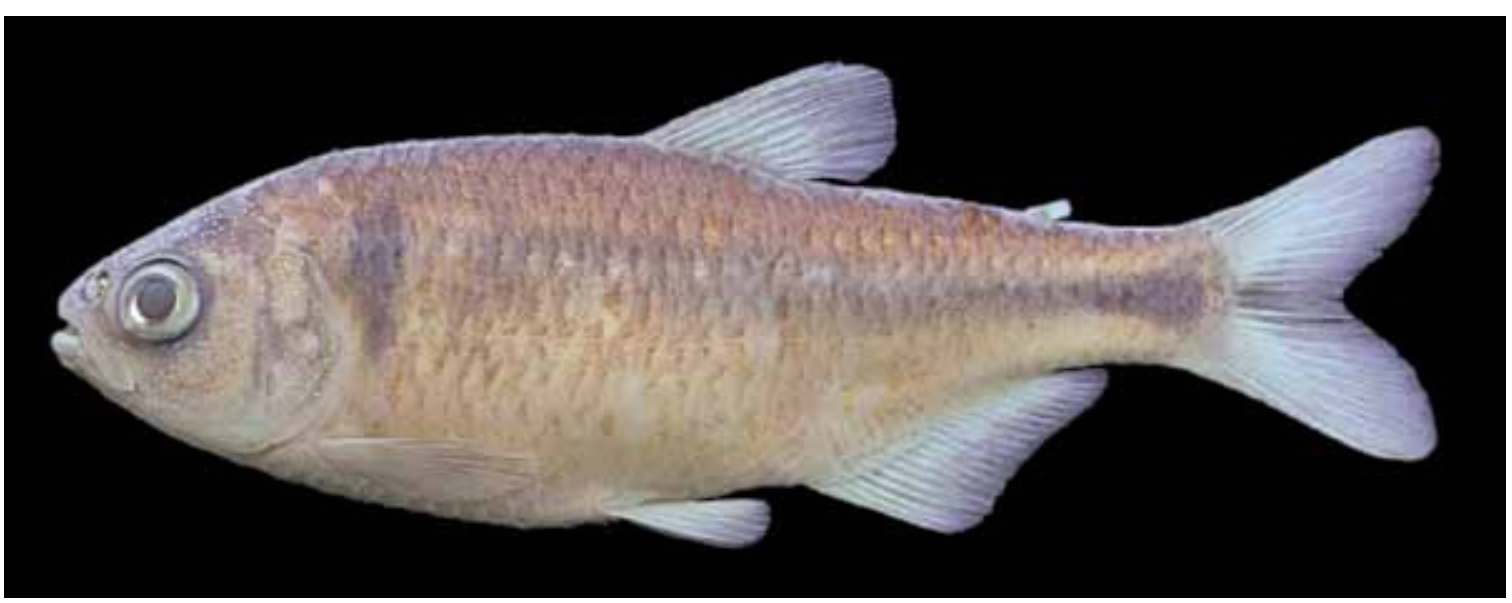

Comprimento padrão 65,8 mm

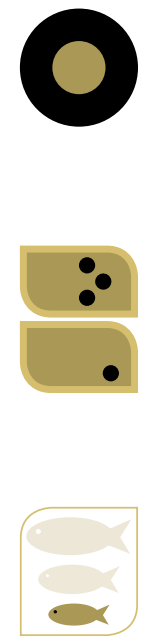

Corpo castanho, mais claro na região ventral e mais escuro na região dorsal, com uma faixa longitudinal marrom escura na lateral do corpo, que se estende da região após a mancha umeral até o final dos raios caudais medianos. Apresenta pigmentação escura na margem das nadadeiras dorsal e anal. Mancha umeral preta, verticalmente alongada, com prolongamento vertical para baixo. Corpo robusto e boca terminal. Margem do $3^{\circ}$ infraorbital separada do pré-opérculo por uma estreita área de pele (área nua).

Altura do corpo contida 2,9 a 3,3 e do pedúnculo caudal 8,4 a 9,3 vezes no CP; comprimento da cabeça 3,6 a 3,8, do pedúnculo caudal 6,7 a 8,1 e pré-dorsal 1,9 a 2,0 vezes no CP. Comprimento do focinho contido 3,0 a 4,1, diâmetro orbital 3,0 a 3,6 e distância interorbital 2,8 a 3,7 vezes no CC.

Possui 5 dentes com 5 cúspides na série interna do pré-maxilar e 4 ou 5 dentes na série externa. Maxilar com 1 a 3 dentes. Linha lateral completa com 35 a 37 escamas, $51 / 2$ a 6 séries de escamas acima da linha lateral e 4 a $4 \frac{1}{2}$ abaixo. Nadadeira dorsal com ii +9 raios, peitoral com i+12 ou 13, pélvica com i+6 ou 7 e anal com iii +17 a 19 raios. Apresenta 6 a 8 rastros branquiais superiores e 8 a 10 inferiores.

Capturada apenas no arroio Laranjal, afluente do rio Iguaçu, em expedição realizada pelo Gerpel, aprensenta características semelhantes a Astyanax leonidas Azpelicueta, Casciotta \& Almirón, 2002, diferindo principalmente no número de dentes do maxilar. 


\section{- Gênero indeterminado sp.}

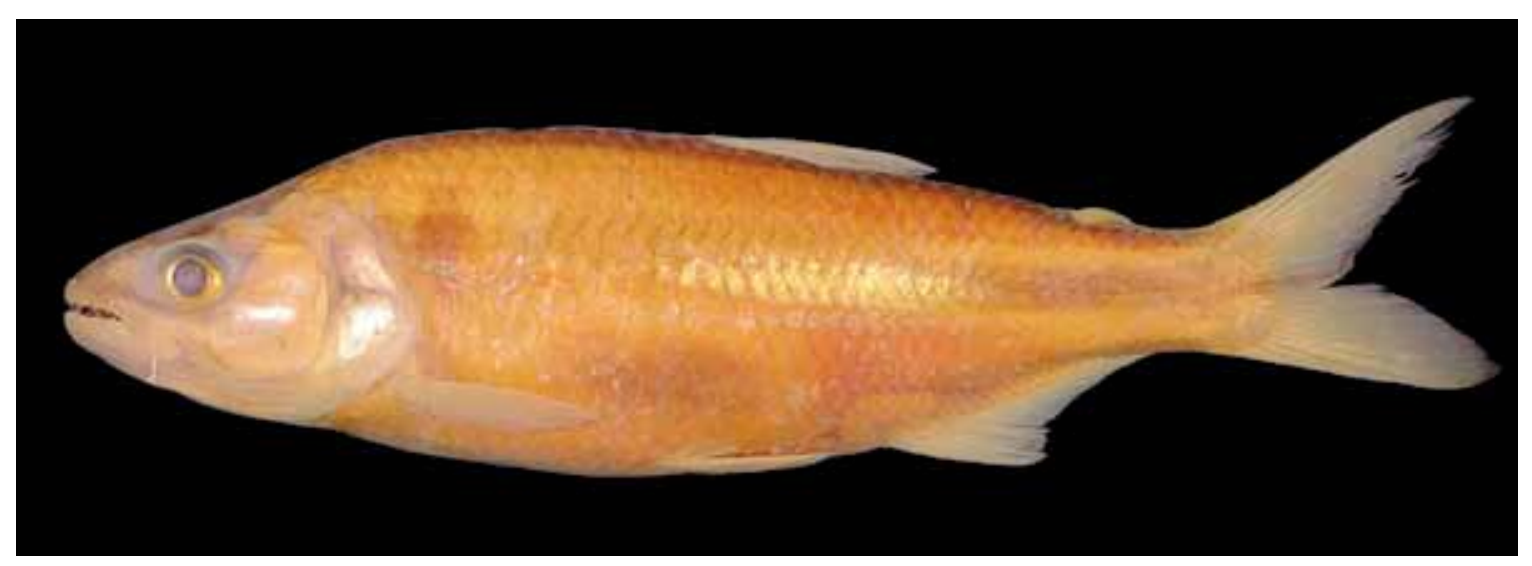

Comprimento padrão 168,0 mm

Corpo claro, escurecendo em direção ao dorso. Mancha umeral cinza-escura, irregularmente arredondada ou alongada verticalmente, geralmente com prolongamento vertical para baixo. Faixa longitudinal escura e larga, mais evidente após a região da mancha umeral, que pode prolongar-se sobre os raios caudais medianos, prateada quando em vida. Boca terminal. $03^{\circ}$ infraorbital e o pré-opérculo separados por uma ampla área de pele (área nua).

Altura do corpo contida 3,4 a $3,5^{*}$ e do pedúnculo caudal 9,8 a 9,9* vezes no $C P$; comprimento da cabeça contido 3,2 a 3,4*, pré-dorsal 1,8 a 1,9* e do pedúnculo caudal 7,9 a $8,4^{*}$ vezes no CP. Comprimento do focinho contido 3,5 a 3,9*, diâmetro orbital 4,7 a 4,8* e distância interorbital 3,9 a 4,0* vezes no CC.

Possui 4 dentes caniniformes na série interna do pré-maxilar e $4 *$ dentes cônicos na série externa. Maxilar com 9 ou 10* dentes cônicos. Linha lateral completa com 42 a $44^{*}$ escamas, 7 a $7 \frac{1}{2^{*}}$ séries acima da linha lateral e 5 a $5 \frac{1 / 2^{*}}{}$ abaixo. Nadadeira dorsal com ii $+9^{*}$ raios, peitoral com $\mathrm{i}+13^{*}$, pélvica com $\mathrm{i}+7$ ou $8^{*}$ e anal com iii +19 ou $20^{*}$ raios. Apresenta $7 *$ rastros branquiais superiores e $10 *$ inferiores.

Esta espécie é raramente capturada, carecendo, além da sua descrição original, de estudos relacionados à sua biologia. Sua distribuição geográfica é aparentemente restrita à bacia do rio Iguaçu. Possui uma fórmula dentária que não coincide com os caracteres dos gêneros de lambaris atualmente descritos, por isso é aqui considerada como espécie nova de um gênero indeterminado, provavelmente novo, que está em estudo por Luiz Roberto Malabarba, Carla Simone Pavanelli e Júlio César Garavello. Esta espécie foi chamada como gênero A por Garavello, Pavanelli e Suzuki (1997).

*Luiz Roberto Malabarba, comunicação pessoal (2010) 
- Hyphessobrycon reticulatus Ellis, 1911

Lambarizinho

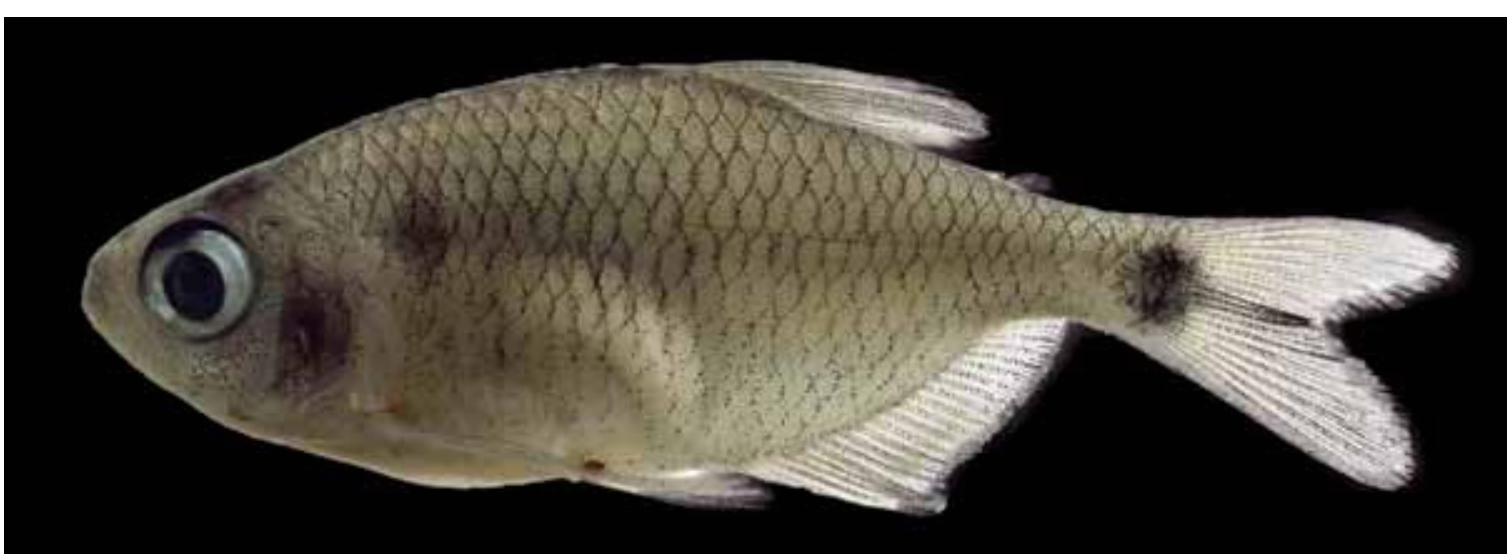

Comprimento padrão 34,3 mm

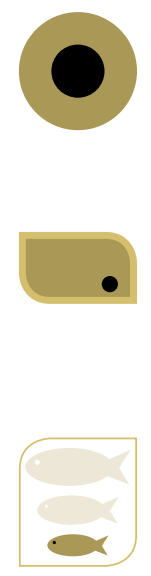

Corpo bege-claro, com uma mancha umeral preta, levemente arredondada, às vezes com estreito prolongamento vertical para baixo, e outra maior, sobre o pedúnculo caudal. Apresenta ainda uma listra longitudinal preta, que se inicia após a metade do corpo e se esmaece antes da mancha do pedúnculo. Uma listra cinza-escura mais estreita ao longo da base da nadadeira anal, às vezes pouco evidente. Escamas com pigmentos escuros na borda, conferindo um aspecto reticulado ao corpo. Nadadeiras ímpares com pigmentos escuros nas porções distais.

Altura do corpo contida 2,5 a 2,6 e do pedúnculo caudal 8,3 a 9,7 vezes no CP; comprimento da cabeça contido 3,5 a 3,7, pré-dorsal 1,5 e do pedúnculo caudal 6,9 a 8,5 vezes no CP. Comprimento do focinho contido 3,8 a 5,5, diâmetro orbital 2,7 a 3,0 e distância interorbital 2,2 vezes no CC.

Possui $5^{*}$ dentes com 3 a $5^{*}$ cúspides na série interna do pré-maxilar, 3 a $5^{*}$ dentes com $3^{*}$ cúspides na série externa e 0 ou $1^{*}$ dente no maxilar (geralmente 1 ). Linha lateral incompleta, com 5 a $7^{*}$ escamas poradas, longitudinal com 31 a 34* escamas, 6 a $7^{*}$ séries de escamas acima e 4 a $5^{*}$ abaixo da linha lateral. Nadadeira dorsal com $11^{*}$ raios, peitoral com i+11 a 13, pélvica com i+6 ou 7 e anal com 18 a $21^{\star}$ raios. Apresenta $7 *$ rastros branquiais superiores e 9 * inferiores.

Essa espécie encontra-se distribuída nas bacias costeiras do Rio de Janeiro e Santa Catarina (LIMA; BUCKUP; MENEZES; LUCENA; LUCENA; TOLEDO-PIZA; ZANATA, 2007) e no rio Iguaçu (SAMPAIO, 1988). Na última, esta espécie tem distribuição geográfica ampla, mas não abundante.

*Ellis (1911) 
- Oligosarcus longirostris Menezes \& Géry, 1983

Saicanga

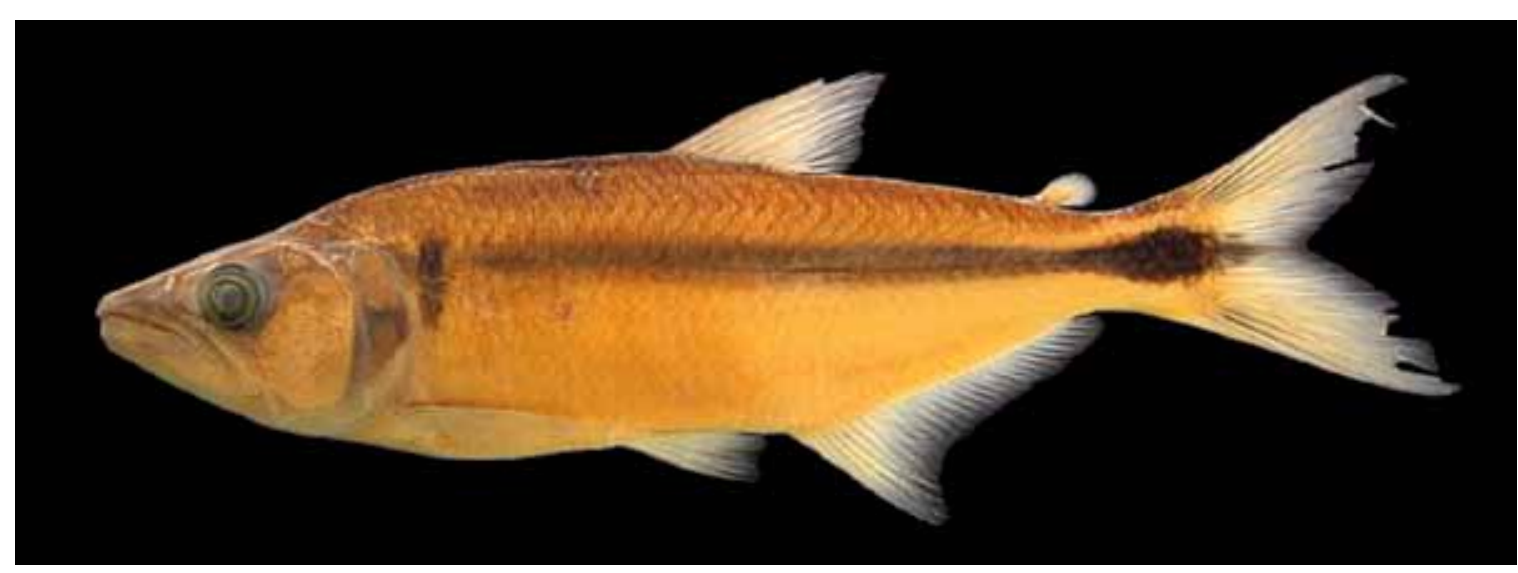

Comprimento padrão $164,6 \mathrm{~mm}$

Corpo amarelo-claro, castanho na região dorsal. Mancha umeral preta verticalmente alongada, e outra mancha preta alongada horizontalmente sobre o pedúnculo caudal. Nadadeiras vermelhas ou amarelas quando em vida, amareladas nos exemplares fixados, com as bordas escurecidas. Faixa longitudinal preta e larga, iniciando-se após a região da mancha umeral e prolongando-se sobre os raios caudais medianos, prateada quando em vida. Focinho pontudo e longo.

Altura do corpo contida 3,4 a 3,9* e do pedúnculo caudal 9,3 a $11,8^{*}$ vezes no CP; comprimento da cabeça contido 2,9 a $3,2^{*}$ e pré-dorsal 1,7 a $1,8^{*}$ vezes no $C P$. Comprimento do focinho contido 3,3 a 3,8* diâmetro orbital 3,6 a 4,7* e distância interorbital 4,4 a $4,8^{*}$ vezes no CC.

Possui numerosos dentes cônicos e bem desenvolvidos, maxilar com 24 a $32^{*}$ dentes e dentário com 14 a 19*. Linha lateral completa com 47 a $51^{*}$ escamas, 9 ou $10^{*}$ séries de escamas acima da linha lateral e 7 a $8^{*}$ abaixo. Nadadeira dorsal com ii $+9^{*}$ raios, peitoral com $i+13$ a $15^{*}$, pélvica com $i+7^{\star}$ e anal com iv +22 a $26^{\star}$ raios. Apresenta 12 a $14^{*}$ rastros branquiais inferiores.

Essa espécie de hábito alimentar piscívoro, apresenta pressão de predação sobre espécies como Cyphocarax santacatarinae, algumas espécies do gênero Astyanax e espécies não identificadas (devido ao elevado estado de decomposição das presas) das famílias Cichlidae e Pimelodidae (HAHN; FUGI; ALMEIDA; RUSSO; LOUREIRO, 1997; UNIVERSIDADE ESTADUAL DE MARINGÁ, 2002). O ritmo alimentar dessa espécie intensifica-se durante o outono na calha central do rio Iguaçu, mas seu ritmo alimentar não apresentou sazonalidade em seus tributários. Esta espécie se reproduz entre julho e março, e os menores indivíduos em atividade reprodutiva foram registrados com $\mathrm{CP}=96,0 \mathrm{~mm}$ tanto em machos quanto fêmeas (UNIVERSIDADE ESTADUAL DO OESTE DO PARANÁ, 2008b, 2009a, 2009b). Sua distribuição geográfica é aparentemente restrita à bacia do rio Iguaçu. 


\section{SUBFAMÍLIA}

\section{Salmininae}

Esta subfamília, caracterizada por apresentar um único gênero, com espécies predadoras, ictiófagas, que habitam principalmente grandes cursos d'água, já teve seu status alterado várias vezes. Foi considerada tribo de Bryconinae por Géry (1977), o gênero Salminus já foi incluído como incertae sedis dentro de Characidae por Lima, Malabarba, Buckup, Silva, Vari, Harold, Benine, Oyakawa, Pavanelli, Menezes, Lucena, Malabarba, Lucena, Reis, Langeani, Casatti, Bertaco, Moreira e Lucinda (2003), mas foi considerada subfamília de Characidae ao longo de décadas por diversos autores, como, entre outros, Britski, Silimon e Lopes (2007). Após recente análise filogenética da família Characidae, publicada por Mirande (2009), ela volta novamente a ter status de subfamília de Characidae, como considerada aqui. Suas poucas espécies ocorrem em várias bacias sulamericanas, mas não são nativas da bacia do rio Iguaçu. Sua única representante na bacia é capturada esporadicamente, apenas na fase adulta.

\section{- Salminus brasiliensis (Cuvier, 1816) \\ Dourado}

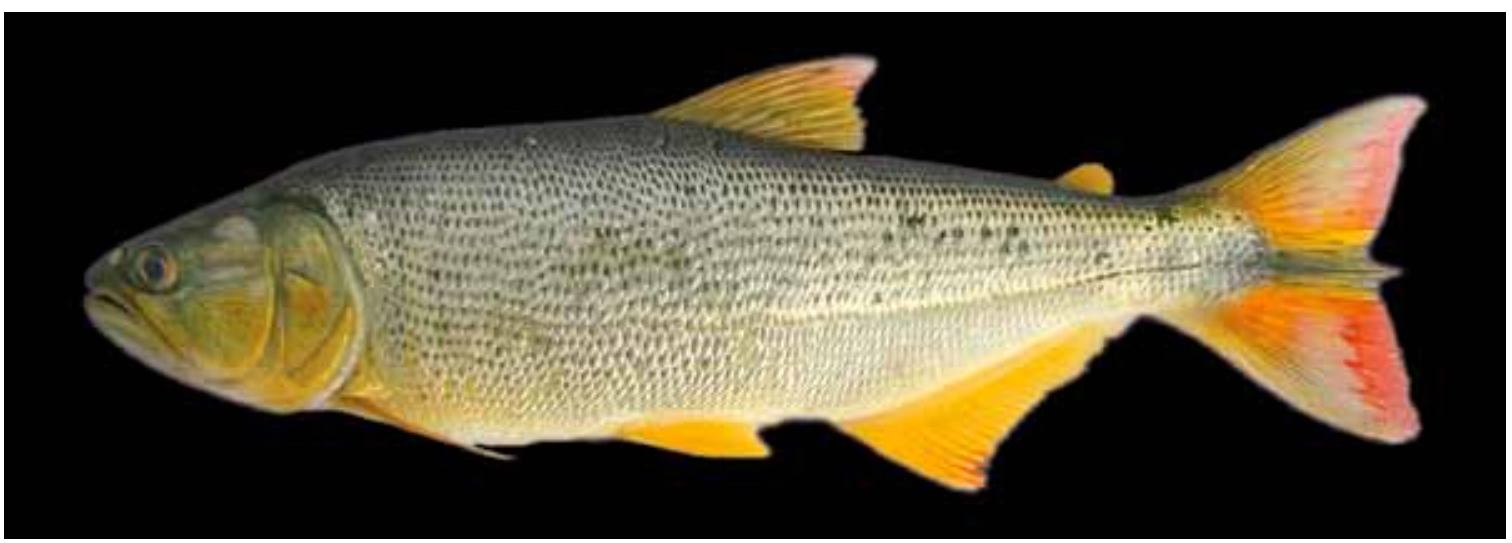

Comprimento padrão 207,3 mm

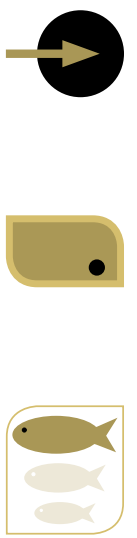

Região superior do corpo acinzentada, ventral amarelo-clara, com coloração amarelo ouro característica, sobretudo na cabeça e nadadeiras, sendo que as últimas também podem se apresentar avermelhadas quando em vida. Mancha preta horizontalmente alongada que se estende do pedúnculo caudal até a extremidade dos raios caudais medianos. Boca ampla e terminal.

Altura do corpo contida 3,6 a $3,7^{*}$ e do pedúnculo caudal 11,3 a $11,5^{*}$ vezes no $\mathrm{CP}$; comprimento da cabeça contido 3,1 a $3,3^{*}$, pré-dorsal 1,8 a $1,9^{*}$ e do pedúnculo caudal 9,3 a 9,6* vezes no CP. Comprimento do focinho contido 3,4 a 4,0*, diâmetro orbital 5,7 a 5,9* e distância interorbital 2,7 a 3,2* vezes no CC.

Possui 9 a $11^{*}$ dentes na série interna do pré-maxilar e $8^{*}$ na externa, série interna do dentário com 40 a 50*, externa com 28 ou $29^{\star}$ e maxilar com 30 a 33* dentes. Linha lateral completa com 93 a 96* escamas, 16 a $18^{*}$ séries de escamas acima da linha lateral e 8 ou 9* abaixo. Nadadeira dorsal com 11 ou 12* raios, peitoral com 15*, pélvica com $9 *$ e anal com 26 a $28 *$ raios. 
Descrita nas bacias dos rios da Prata, Mamoré e drenagens da Laguna dos Patos, seu primeiro registro no rio Iguaçu ocorreu no reservatório de Salto Santiago em janeiro de 2008 (GUBIANI; FRANA; MACIEL; BAUMGARTNER, 2010).

Apresenta hábito alimentar piscívoro e realiza grandes migrações para reprodução (SUZUKI; VAZZOLER; MARQUES; LIZAMA; INADA, 2004) em suas bacias de origem. No rio Iguaçu ela não é nativa, sendo sua captura esporádica e restrita a exemplares adultos, indicando que sua ocorrência pode ser devida ao escape de pisciculturas.

*Graça e Pavanelli (2007)

SUBFAMÍLIA

\section{Bryconinae}

Membros dessa subfamília não são nativos da ictiofauna do rio Iguaçu. Nas bacias onde ocorrem, entretanto, são bastante apreciados na pesca, pois apresentam portes de médio a grande. Caracterizam-se por apresentar três (raramente quatro) séries de dentes no pré-maxilar, dentes maiores na série interna do pré-maxilar, um dente sinfisiano atrás da série de dentes principal do dentário (LIMA, 2003), nadadeira anal longa e linha lateral bem abaixo do meio do flanco (BRITSKI; SILIMON; LOPES, 2007). 


\section{- Brycon hilarii (Valenciennes, 1850)}

Piraputanga

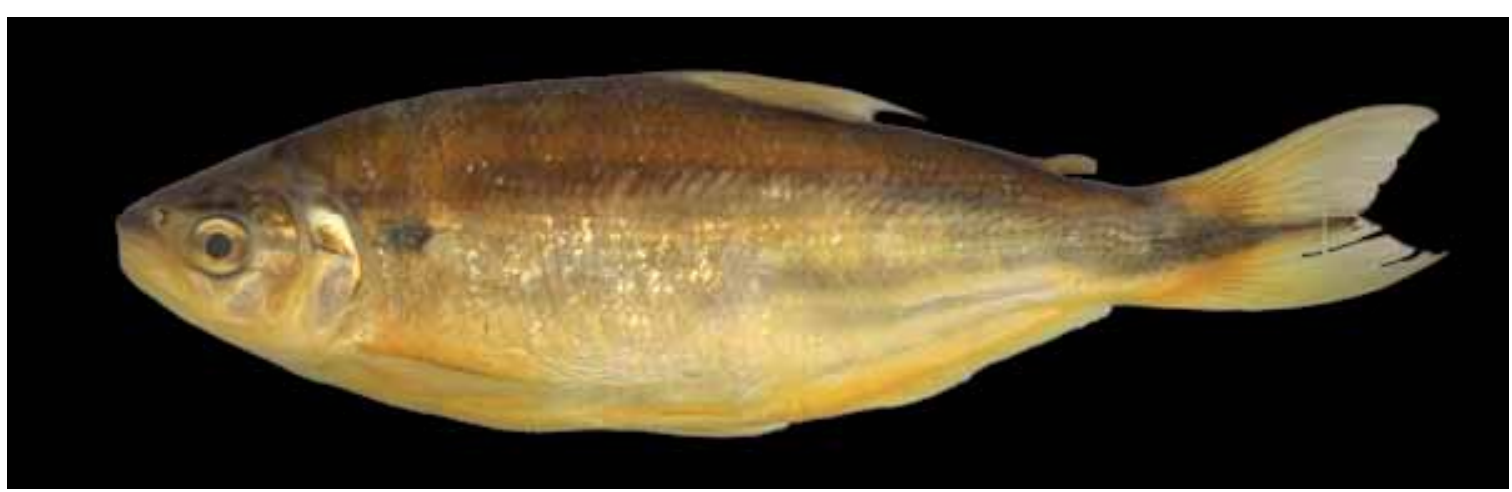

Comprimento padrão 250,2 mm

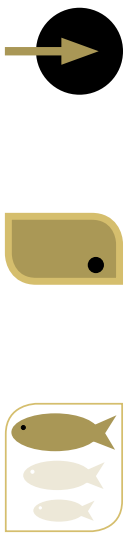

Região superior do corpo acinzentada, ventral amarelo-clara. Mancha umeral preta alongada horizontalmente. As nadadeiras pélvica, anal e caudal podem se apresentar avermelhadas quando em vida. Mancha umeral preta levemente arredondada e outra longitudinalmente alongada que se estende do pedúnculo caudal até a extremidade dos raios caudais medianos. Faixa longitudinal cinza-escuro, muitas vezes inconspícua na lateral do corpo. Boca terminal.

Altura do corpo contida 2,8 a 3,9* e do pedúnculo caudal 8,6 a $11,8^{*}$ vezes no $\mathrm{CP}$; comprimento da cabeça 2,9 a $4,7^{*}$, pré-dorsal 1,8 a $2,2^{*}$ e do pedúnculo caudal 5,6 a $8,1^{*}$ vezes no CP. Comprimento do focinho contido 2,9 a $3,8^{*}$, diâmetro orbital 3,3 a $5,1^{*}$ e distância interorbital de 1,9 a $2,8 *$ vezes no CC.

Possui $3^{*}$ séries de dentes no pré-maxilar, sendo que a série interna possui 4 a $6^{*}$ dentes com 3 a $5^{\star}$ cúspides, a externa possui 7 a 13* dentes com $3^{*}$ cúspides e a série central apresenta 3 a $5^{*}$ dentes com $3^{*}$ cúspides. Maxilar com 11 a 23* dentes. Linha lateral completa com 65 a $82^{*}$ escamas, 11 a 17* séries de escamas acima da linha lateral e 6 a $9^{*}$ abaixo. Nadadeira dorsal com $\mathrm{ii}+9^{*}$ raios, peitoral com i+12 a 15*, pélvica com $\mathrm{i}+7^{*}$ e anal com $\mathrm{iii}+19$ a $27^{*}$ raios. Apresenta 14 a $18^{*}$ rastros branquiais superiores e 12 a $18 *$ inferiores.

Esta espécie, na bacia do rio Paraguai, é considerada onívora, alimentando-se principalmente de insetos e vegetais (BRITSKI; SILIMON; LOPES, 1999). Não apresenta cuidado parental e realiza grandes migrações (SUZUKI; VAZZOLER; MARQUES; LIZAMA; INADA, 2004). Nativa de bacia do rio Paraguai, sua captura no rio Iguaçu é esporádica e restrita a exemplares adultos, indicando que sua ocorrência pode ser devida ao escape de pisciculturas.

*Lima (2001) 


\section{Stevardiinae}

Após muitos anos considerada como sinônimo de Glandulocaudinae, esta subfamília foi recentemente validada por Mirande (2009), que redefiniu e ampliou a abrangência deste grupo, agora incluindo representantes do clado A de Malabarba e Weitzman (2003), entre outros. Os gêneros da bacia do rio Iguaçu que são atualmente alocados nesta subfamília já foram considerados pertencentes a Tetragonopterinae e incertae sedis em Characidae pela maioria dos autores, em épocas diferentes. São espécies de pequeno porte que se caracterizam basicamente por apresentar quatro dentes na série interna do pré-maxilar.

\section{Chave para espécies de Bryconamericus}

1. Mancha umeral preta, grande e arredondada, bem evidente; série externa de dentes do pré-maxilar com três dentes

1'. Mancha umeral cinza-escura, ou preta, estreita e alongada verticalmente, às vezes pouco conspícua; série externa do pré-maxilar com quatro a seis dentes (raramente três)

2. Corpo alto, sua altura contida no máximo três vezes no comprimento padrão; cabeça grande, seu comprimento contido menos de quatro vezes no comprimento padrão; nadadeira anal com 21 a 26 raios

2'. Corpo baixo, sua altura contida mais de três vezes no comprimento padrão; cabeça pequena, seu comprimento contido quatro vezes ou mais no comprimento padrão; nadadeira anal com 19 a 22 raios .... Bryconamericus sp. 
- Bryconamericus ikaa Casciotta, Almirón \& Azpelicueta, 2004 Lambarizinho

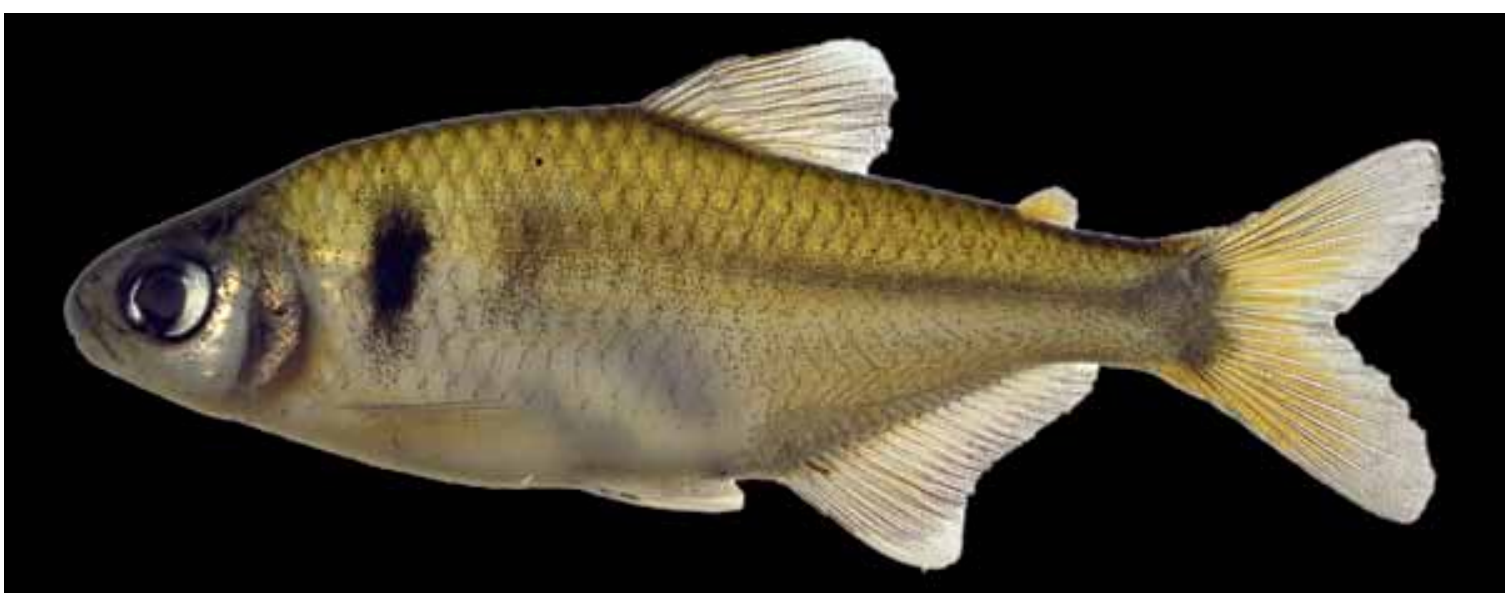

Comprimento padrão 54,8 mm

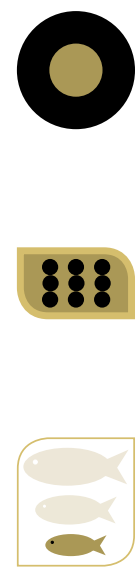

Corpo bege-claro, mais escuro dorsalmente, prateado quando em vida. Mancha umeral preta verticalmente alongada, com prolongamentos inconspícuos para cima e para baixo, seguida por outra mancha castanha, difusa e muitas vezes inconspícua. Faixa longitudinal castanha, mais evidente a partir da segunda mancha umeral, que não se prolonga sobre os raios caudais medianos. Nadadeiras hialinas, que podem apresentar-se avermelhadas ou amareladas quando em vida, normalmente com pigmentos escuros dispersos em seus terços distais. Boca subterminal.

Altura do corpo contida 2,7 a 3,0* e do pedúnculo caudal 8,4 a 9,0* vezes no CP; comprimento da cabeça contido 3,5 a 3,9*, pré-dorsal 1,8 a $1,9 *$ e do pedúnculo caudal 7,5 a 8,6* vezes no CP. Comprimento do focinho contido 3,7 a 4,3*, diâmetro orbital 2,7 a 3,1* e distância interorbital 3,3 a 3,8* no CC.

Possui $4^{*}$ dentes na série interna do pré-maxilar, com 3 a $5^{\star}$ cúspides. Série externa com 4 a $6^{*}$ dentes, com 3 ou $4^{*}$ cúspides e 3 ou 4* dentes no maxilar. Linha lateral completa com 36 a 38* escamas, $5^{*}$ séries de escamas acima e 31/2 a 41/2* abaixo da linha lateral. Nadadeira dorsal com $\mathrm{ii}+8^{*}$ raios, peitoral com i+10 a $12^{*}$, pélvica com $\mathrm{i}+7^{\star}$ e anal com iii-iv +21 a $26^{*}$ raios. Apresenta 6 ou 7 rastros branquiais superiores e 9 ou 10 inferiores.

Esta espécie possui hábito alimentar onívoro, com consumo de diversos itens, tendo sido fortemente afetada pela formação do reservatório de Salto Caxias, que proporcionou a deposição do material particulado, limitando a espécie à condição de detritívora (DELARIVA, 2002). O período reprodutivo desta espécie ocorre entre agosto e janeiro (UNIVERSIDADE ESTADUAL DE MARINGA, 2002), e os menores indivíduos em atividade reprodutiva foram registrados com $C P=50,0 \mathrm{~mm}$ nas fêmeas e $C P=55,0 \mathrm{~mm}$ nos machos (UNIVERSIDADE ESTADUAL DO OESTE DO PARANÁ, 2010). Sua distribuição geográfica é aparentemente restrita à bacia do rio Iguaçu, tendo sido registrada por Garavello, Pavanelli e Suzuki (1997), Universidade Estadual de Maringá (2002) e Baumgartner, Baumgartner, Pavanelli, Silva, Frana, Oliveira e Michelon (2006). Antes de sua descrição, esta espécie era conhecida na bacia do rio Iguaçu como Bryconamericus sp. A, a partir de Sampaio (1988).

*Casciotta, Almirón e Azpelicueta (2004) 
- Bryconamericus pyahu Azpelicueta, Casciotta \& Almirón, 2003 Lambarizinho

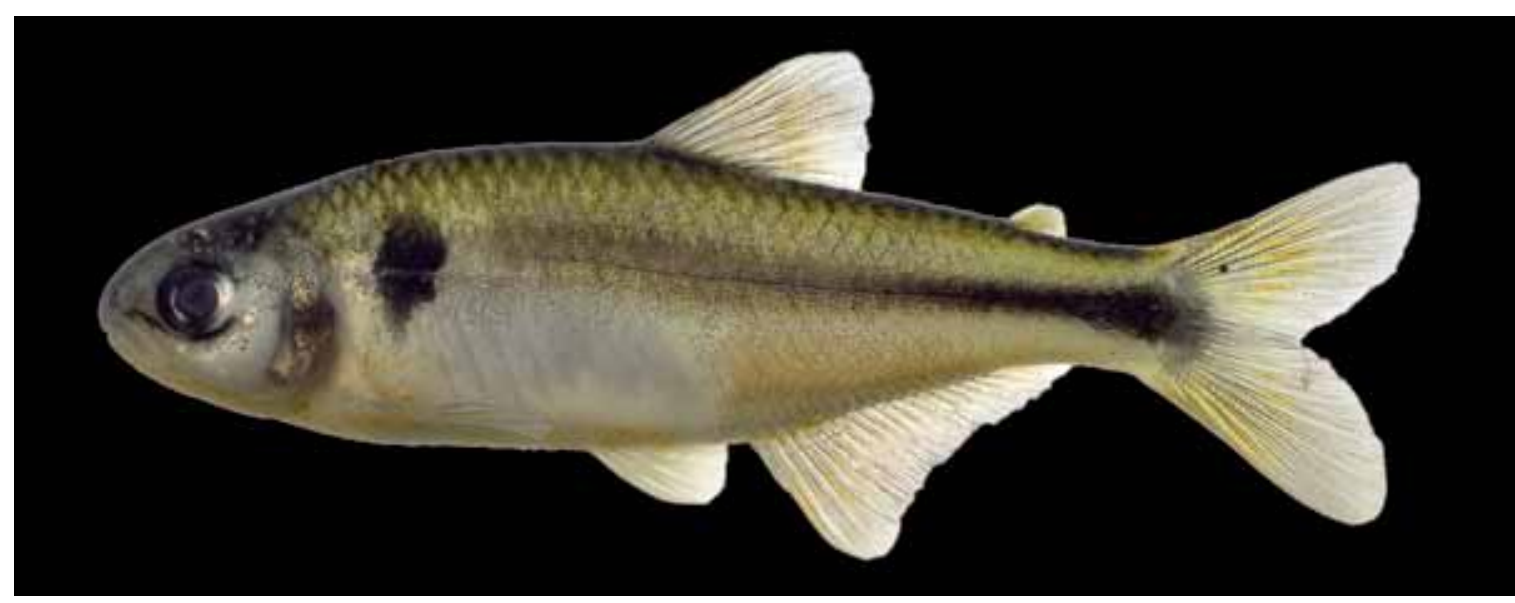

Comprimento padrão 49,9 mm

Corpo bege-claro, mais escuro dorsalmente, prateado quando em vida. Mancha umeral preta, grande e arredondada, sem prolongamentos para cima e para baixo. Faixa longitudinal preta, mais evidente após a mancha umeral, mais larga sobre o pedúnculo caudal, formando uma mancha horizontalmente alongada, que pode se prolongar fracamente sobre os raios caudais medianos. Nadadeiras hialinas, normalmente com pigmentos escuros dispersos em seus terços distais. Boca subterminal.

Altura do corpo contida 2,9 a 3,6* e do pedúnculo caudal 8,2 a 9,5* vezes no $C P$; comprimento da cabeça contido 3,6 a 4,0*, pré-dorsal 1,9 a 2,0* e do pedúnculo caudal 5,5 a 6,8* vezes no CP. Comprimento do focinho contido 3,6 a 4,4*, diâmetro orbital 2,6 a 3,3* e distância interorbital 3,4 a 4,0* vezes no CC.

Possui $4^{*}$ dentes na série interna do pré-maxilar, com 3 a $5^{*}$ cúspides. Série externa com $3^{*}$ dentes, com $3^{*}$ cúspides, e maxilar com 3 a $5^{*}$ dentes contendo 1 a $3^{*}$ cúspides. Linha lateral completa com 37 a $39^{*}$ escamas, $5^{*}$ séries de escamas acima e $31 / 2$ a $4^{*}$ abaixo da linha lateral. Nadadeira dorsal com ii $+8^{*}$ raios, peitoral com i+11 ou $12^{*}$, pélvica com i+7* e anal com iii-iv +21 a $24^{*}$ raios. Apresenta 4 a $5^{*}$ rastros branquiais superiores e $9^{*}$ inferiores.

Sua distribuição geográfica é aparentemente restrita à bacia hidrográfica do rio Iguaçu. Não há estudos disponíveis sobre sua biologia. Antes de sua descrição, esta espécie era conhecida na bacia do rio Iguaçu como Bryconamericus sp. B, a partir de Garavello, Pavanelli e Suzuki (1997). 


\section{- Bryconamericus sp. Lambarizinho}

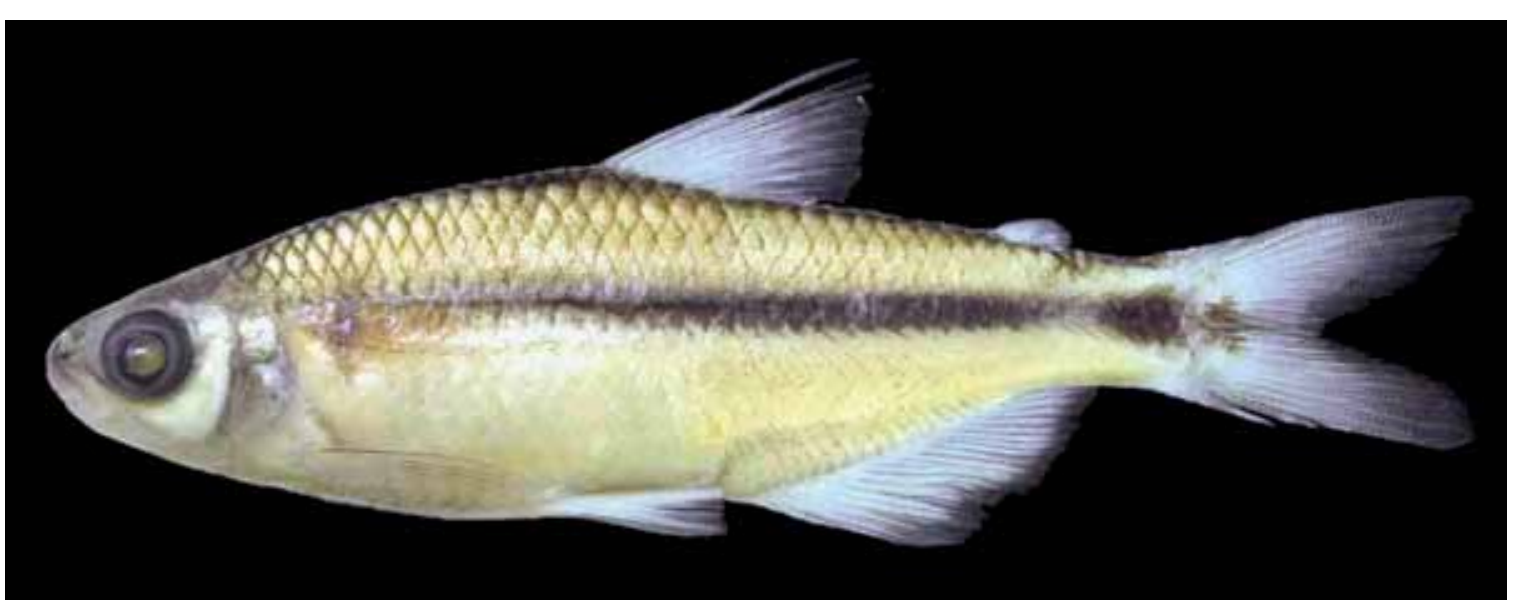

Comprimento padrão 50,1 mm

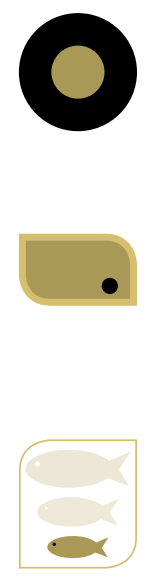

Corpo bege-claro, mais escuro dorsalmente, prateado quando em vida. Mancha umeral castanho-escura, difusa e verticalmente alongada, às vezes com pequenos prolongamentos para cima e para baixo. Faixa longitudinal preta, mais larga sobre o pedúnculo caudal, formando uma mancha arredondada ou horizontalmente alonga$\mathrm{da}$, que pode prolongar-se fracamente sobre os raios caudais medianos. Nadadeiras hialinas, normalmente com pigmentos escuros dispersos em seus terços distais. Boca subterminal.

Altura do corpo contida 3,2 a 3,7 e do pedúnculo caudal 9,3 a 10,5 vezes no CP; comprimento da cabeça 4,0 a 4,3, pré-dorsal 1,9 a 2,0 e do pedúnculo caudal 8,4 a 9,7 vezes no CP. Comprimento do focinho contido 4,0 a 5,0, diâmetro orbital 2,4 a 2,8 e distância interorbital 3,1 a 3,7 vezes no CC.

Possui 4 dentes com 3 cúspides na série interna do pré-maxilar. Série externa com 3 ou 4 dentes e 2 ou 3 dentes no maxilar. Linha lateral completa com 37 ou 38 escamas, $5 \frac{1}{2} 2$ séries de escamas acima e $4 \frac{1}{2}$ ou 5 séries abaixo da linha lateral. Nadadeira dorsal com ii+8 raios, peitoral com i+11 a 13, pélvica com i+7 e anal com ii+17 a 20 raios. Apresenta 6 ou 7 rastros branquiais superiores e 7 a 9 inferiores.

Esta espécie inicia a atividade reprodutiva com $\mathrm{CP}=45,0 \mathrm{~mm}$ tanto para machos como para fêmeas (SUZUKI; AGOSTINHO, 1997). Sua distribuição geográfica é aparentemente restrita à bacia do rio Iguaçu. 
- Cyanocharax aff. alburnus (Hensel,1870) Lambarizinho

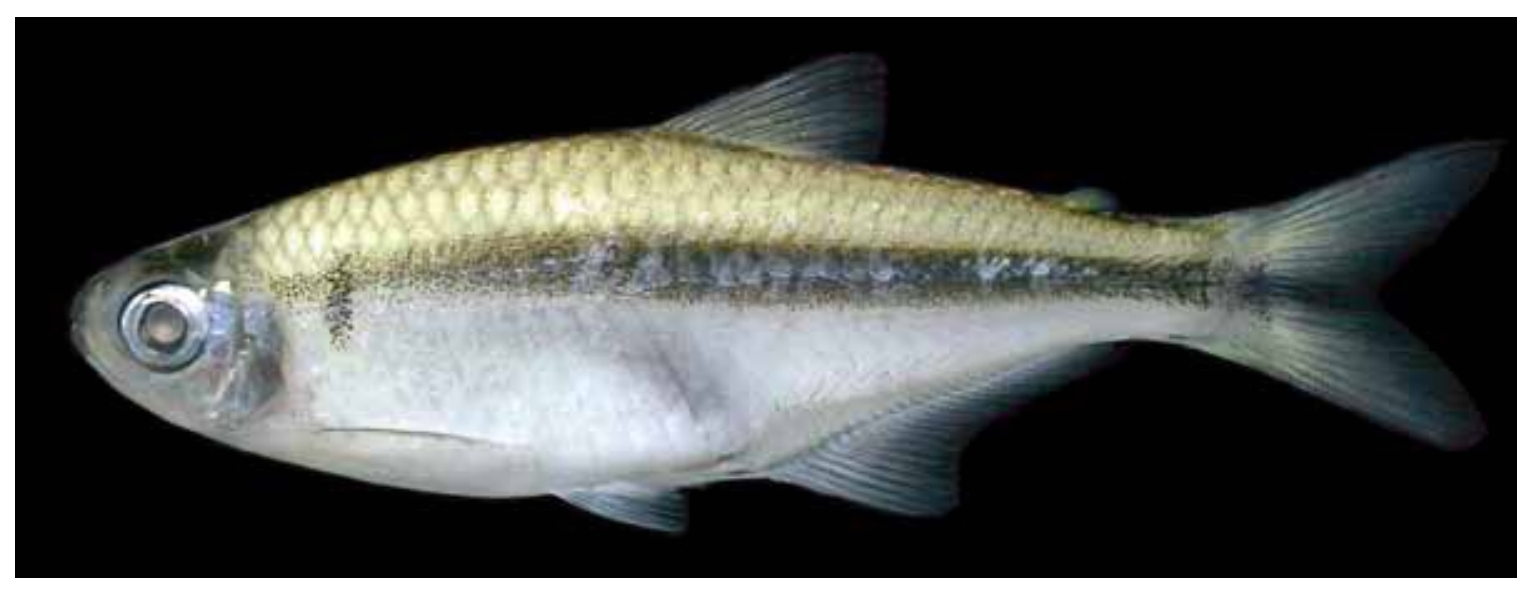

Comprimento padrão 58,6 mm

Corpo esbranquiçado abaixo da linha lateral, amarelado acima, com concentração de pigmentos escuros na região dorsal do corpo e cabeça. Nadadeiras hialinas com poucos pigmentos escuros dispersos. Mancha umeral preta, pequena e alongada verticalmente. Faixa longitudinal larga e escura, às vezes formando uma mancha preta horizontalmente alongada sobre o pedúnculo caudal, estendendo-se sobre os raios caudais medianos. Boca terminal.

Altura do corpo contida 3,1 a 3,7 e do pedúnculo caudal 10,4 a 12,2 vezes no CP; comprimento da cabeça contido 4,5 a 4,9, pré-dorsal 1,8 a 1,9 e do pedúnculo caudal 7,1 a 8,5 vezes no CP. Comprimento do focinho contido 4,2 a 5,6, diâmetro orbital 2,1 a 2,5 e distância interorbital 2,6 a 3,1 vezes no CC.

Possui 4 ou 5 dentes com 5 cúspides na série interna do pé-maxilar. Série externa com 3 a 5 dentes e 1 ou 2 dentes no maxilar. Linha lateral completa com 35 a 37 escamas, 5 ou $5 \frac{1}{2} 2$ séries de escamas acima e 4 abaixo da linha lateral. Nadadeira dorsal com ii +8 raios, peitoral com i+10 a 12 , pélvica com i+6 e anal com ii +22 a 24 raios. Apresenta 7 a 9 rastros braquiais superiores e 10 a 12 inferiores.

Alimenta-se de insetos terrestres (DELARIVA, 2002) e seu período reprodutivo ocorre de setembro a novembro (UNIVERSIDADE ESTADUAL DE MARINGÁ, 2002). Descrita do Rio Grande do Sul e considerando sua distribuição geográfica original, que não inclui a bacia do rio Iguaçu, esta espécie era conhecida no Iguaçu como Bryconamericus sp. C, a partir de Garavello, Pavanelli e Suzuki (1997). Entretanto, após comparações com a descrição original e exame por Luiz Roberto Malabarba (informação verbal), verificamos que o número de raios da nadadeira pélvica $(i+6)$ difere do encontrado nos Bryconamericus ( $i+7)$ e confere com a diagnose do novo gênero.

Análises morfológicas e moleculares realizadas por Felipe A. S. Santos, Nelson Fagundes e Luiz R. Malabarba revelaram que as populações do rio Iguaçu diferem das do Rio Grande do Sul no número de raios das nadadeiras anal e peitoral. Esta espécie é aparentemente nova, está em estudo por Malabarba e colaboradores, e é aqui chamada de $C$. aff. alburnus. 


\section{- Mimagoniates microlepis (Steindachner, 1877)}

Piabinha

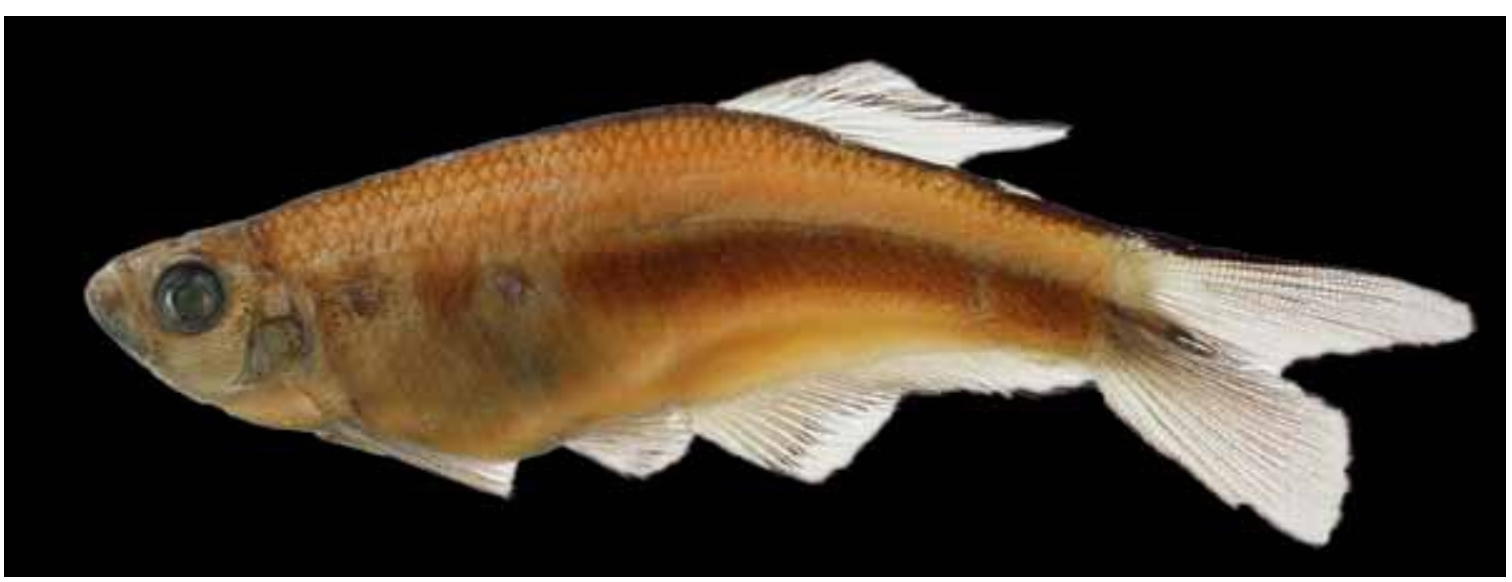

Comprimento padrão 50,0 mm

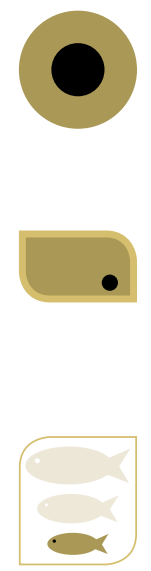

Corpo castanho-claro, mais escuro na região acima da faixa longitudinal, a qual é castanho-escura, larga e se inicia após a mancha umeral. Possui uma faixa preta e estreita no dorso do corpo, que se estende do final da nadadeira dorsal até o final dos primeiros raios do lobo superior da nadadeira caudal, e pigmentação escura nas extremidades das nadadeiras anal e pélvica. Boca superior, com a fenda inclinada para baixo. Origem da nadadeira dorsal posterior à vertical que passa sobre a origem da nadadeira anal, cuja base não apresenta bainha de escamas. Os machos adultos apresentam as escamas da base da nadadeira caudal modificadas.

Altura do corpo contida 3,3 a 3,7 e do pedúnculo caudal 7,3 a 8,9 vezes no $C P$; comprimento da cabeça contido 4,3 a 4,5 e pré-dorsal 1,6 a 1,8 vezes no CP. Comprimento do focinho contido 4,1 a 4,7, diâmetro orbital 2,6 a 2,8 e distância interorbital 3,1 a 3,5 vezes no CC.

Possui duas séries de dentes no pré-maxilar pouco definidas, sendo a externa com 2 a 6 e a interna com 4 a 6 dentes e 3 a 6 dentes no maxilar. Linha lateral incompleta com 6 a 8 escamas perfuradas, linha longitudinal com 43 a 46* escamas. Nadadeira dorsal com 9 ou 10 raios, peitoral com 10 ou 11, pélvica com 7 e anal com 30 a $34 *$ raios.

Apresenta hábito alimentar constituído basicamente por artrópodes alóctones, principalmente insetos e microcrustáceos (LAMPERT; AZEVEDO; FIALHO, 2003). Os machos adultos possuem uma estrutura complexa resultante de uma modificação de escamas e raios da nadadeira caudal, formando o chamado órgão caudal. Anteriormente alocada na subfamília Glandulocaudinae, depois incertae sedis em Characidae, é incluída em Stevardiinae após validação e redefinição da subfamília por Mirande (2009). Sua distribuição geográfica, anteriormente registrada ao longo das bacias costeiras do sul do Estado da Bahia até o norte do Rio Grande do Sul, incluía o alto rio Iguaçu e posteriormente o alto rio Tibagi (MENEZES; RIBEIRO; WEITZMAN; TORRES, 2008), e é aqui ampliada também para o baixo rio Iguaçu.

*Ingenito, Duboc e Abilhoa (2004) 


\section{FAMÍLIA

Com comportamento sedentário e emboscador, as espécies dessa família não realizam grande migrações, deslocando-se o mínimo possível. Seus exemplares caracterizam-se por apresentar corpo cilíndrico, nadadeira caudal arredondada, nadadeira dorsal com 8 a 15 raios, nadadeira anal com 10 ou 11 raios, nadadeira adiposa e fontanela ausentes e apresentam vários dentes caniniformes (OYAKAWA, 2003).

\section{Chave para espécies de Hoplias}

1. Região gular de coloração uniforme; linha lateral com 38 a 40 escamas perfuradas; olho grande, contido 5,1 a 6,0 vezes no comprimento da cabeça Hoplias sp. 1

$\mathbf{1}^{\prime}$. Região gular com faixas claras e escuras intercaladas; linha lateral com 42 a 44 escamas perfuradas; olho pequeno, contido 6,1 a 6,4 vezes no comprimento da cabeça Hoplias sp. 2

- Hoplias sp. 1

Traíra

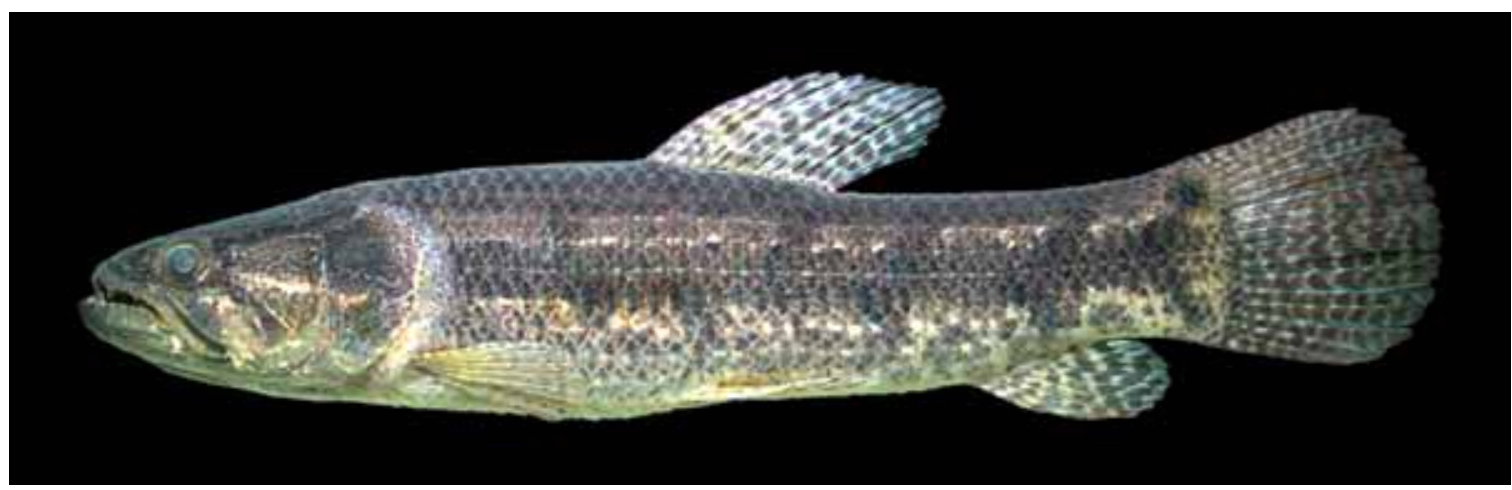

Comprimento padrão $174,0 \mathrm{~mm}$

Corpo castanho, mais escuro na região acima da linha lateral, amarelado abaixo, com manchas marrons ou cinza-escuras, irregularmente distribuídas sobre todo o corpo, às vezes unidas, conferindo uma coloração marrom quase uniforme a quase todo o corpo, excluindo apenas a região ventral. Faixas transversais cinza-escuras ou pretas, irregulares e oblíquas. Nadadeiras claras, com pintas cinzas ou marrom-escuras, muitas vezes formando listras irregulares. Região gular de coloração uniforme, sem faixas definidas. Nadadeira caudal com borda arredondada. Fenda bucal ampla, pré-maxilares e dentários com dentes caninos, palato com dentes e nadadeira adiposa ausente.

Altura do corpo contida 3,8 a 4,8 e do pedúnculo caudal 6,6 a 7,4 vezes no $C P$; comprimento da cabeça contido 3,1 a 3,4, pré-dorsal 1,9 a 2,0 e do pedúnculo caudal 6,9 a 9,5 vezes no CP. Altura da cabeça contida 1,7 a 1,9, comprimento do focinho 4,0 a 4,3, diâmetro orbital 5,1 a 6,0 e distância interorbital 3,5 a 4,0 vezes no CC. 
Linha lateral com 38 a 40 escamas perfuradas, que se iniciam após 2 ou 3 escamas sem poro logo após o opérculo, 5 a 6 séries de escamas acima e 5 abaixo da linha lateral. Nadadeira dorsal com ii-iii +11 ou 12 raios, peitoral com i+10 a 13, pélvica com i+7 ou 8 e anal com ii-iii +8 ou 9 raios.

Nos reservatórios de Salto Santiago e Salto Osório, os menores indivíduos em reprodução desta espécie foram registrados com $C P=181,0 \mathrm{~mm}$ nos machos e $\mathrm{CP}=176,0$ mm nas fêmeas (UNIVERSIDADE ESTADUAL DO OESTE DO PARANÁ, 2008b, 2009a, 2009b).

Hoplias sp. 1 pertence ao complexo de espécies atualmente identificadas como Hoplias malabaricus, amplamente distribuído em toda a América Latina (OYAKAWA, 2003). Sua ocorrência na bacia do rio Iguaçu é frequente, e estudos comparativos desta espécie com as congêneres da bacia adjacente do rio Paraná indicam que deva ser uma espécie diferente. Está em estudo por Alessandro Bifi, Carla Pavanelli e Osvaldo Oyakawa.

- Hoplias sp. 2

Traíra

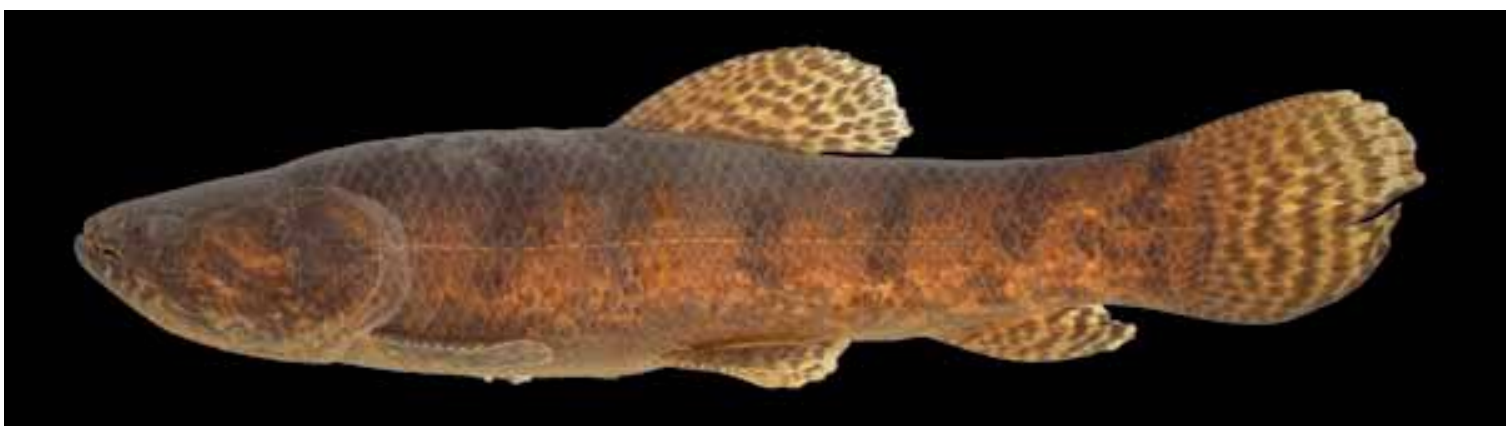

Comprimento padrão 244,5 mm

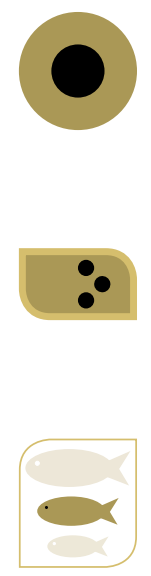

Corpo castanho, mais escuro na região acima da linha lateral, amarelado abaixo, com manchas marrons ou cinza-escuras, irregularmente distribuídas sobre todo o corpo, às vezes unidas, conferindo uma coloração marrom quase uniforme a quase todo o corpo, excluindo apenas a região ventral. Faixas transversais cinza-escuras ou pretas, irregulares, na lateral do corpo. Nadadeiras claras, com pintas cinzas ou marrom-escuras, muitas vezes formando listras irregulares. Região gular com faixas escuras e claras intercaladas. Nadadeira caudal com borda arredondada. Fenda bucal ampla, pré-maxilares e dentários com dentes caninos, palato com dentes e nadadeira adiposa ausente.

Altura do corpo contida 4,0 a 4,7 e do pedúnculo caudal 7,2 a 8,1 vezes no $C P$; comprimento da cabeça contido 3,1 a 3,4, pré-dorsal 1,9 a 2,1 e do pedúnculo caudal 7,3 a 9,1 vezes no CP. Altura da cabeça contida 1,7 a 1,9, comprimento do focinho 4,0 a 4,2, diâmetro orbital 6,1 a 6,4 e distância interorbital 3,7 a 4,0 vezes no CC.

Linha lateral com 42 a 44 escamas perfuradas, que se iniciam após 2 ou 3 escamas sem poro logo após o opérculo, 6 a 7 escamas acima e 6 abaixo da linha lateral. Nadadeira dorsal com ii+11 ou 12 raios, peitoral com i+13 ou 14, pélvica com i+7 e anal com ii-iii+8 ou 9 raios. 
Hoplias sp. 2 pertence ao complexo de espécies atualmente identificadas como Hoplias malabaricus, amplamente distribuído em toda a América Latina (OYAKAWA, 2003). Sua ocorrência na bacia do rio Iguaçu é aparentemente restrita à região do reservatório da UHE de Salto Caxias, e estudos comparativos desta espécie com as congêneres da bacia adjacente do rio Paraná indicam que deva ser uma espécie diferente. Está em estudo por Alessandro Bifi, Carla Pavanelli e Osvaldo Oyakawa. 


\section{Ordem}

\section{SILURIFORMES}

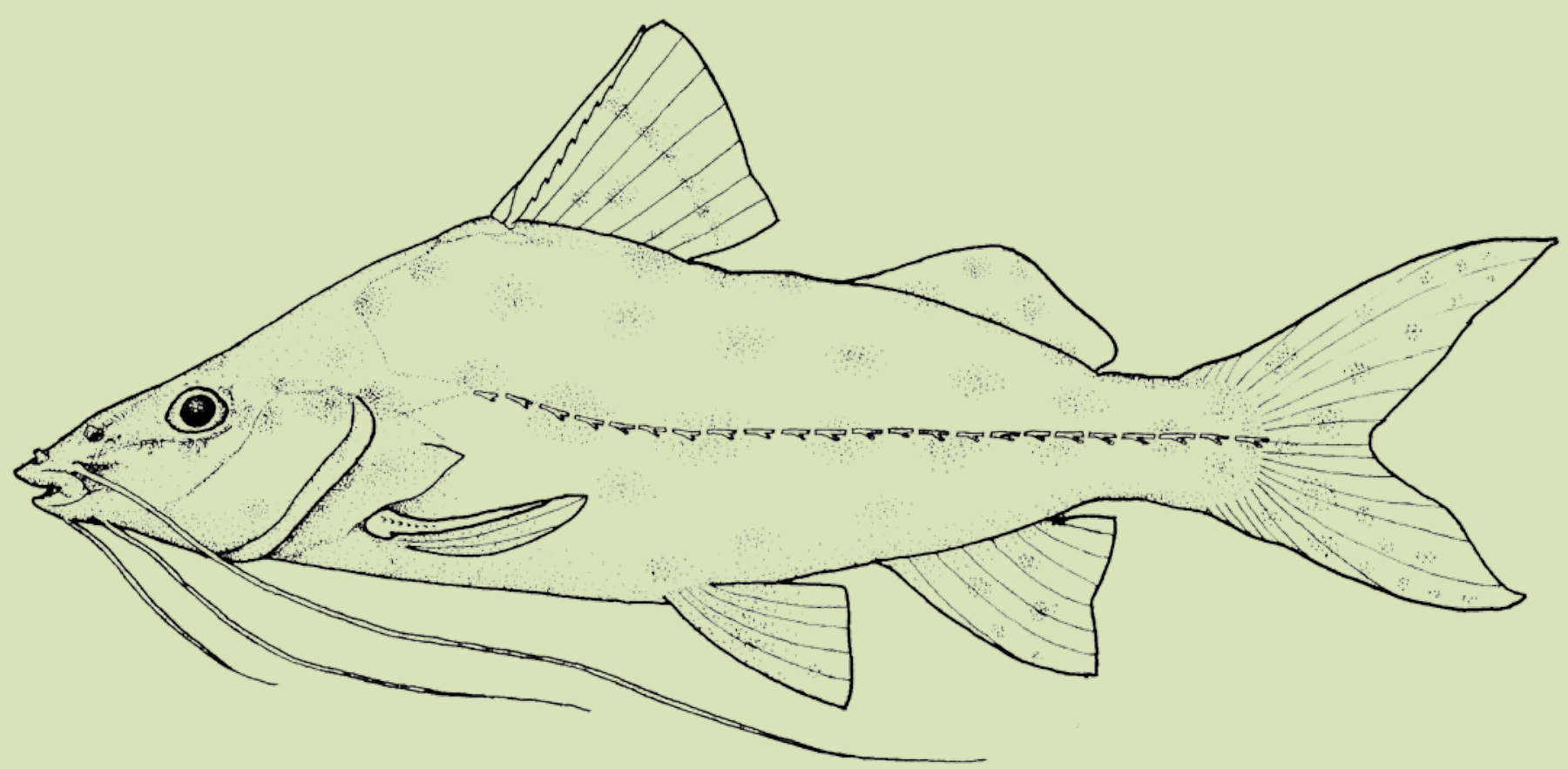

Uma das grandes ordens de peixes da região neotropical, possui vários representantes na bacia do rio Iguaçu. Suas espécies possuem o corpo nu ou revestido por placas dérmicas e apresentam hábitos geralmente associados às porções mais próximas do substrato. Embora com várias espécies nesta bacia, muitos gêneros presentes na bacia do rio Paraná estão ausentes da fauna original do rio Iguaçu, incluindo os grandes migradores reprodutivos com importância comercial. $O$ endemismo da ictiofauna do rio Iguaçu é marcante nas espécies desta ordem, mas também várias espécies não nativas têm sido introduzidas acidental ou deliberadamente na bacia. 


\section{FAMÍLIAS}

Trichomycteridae

\section{Callichthyidae}

Loricariidae

Neoplecostominae

Hypoptopomatinae

Loricariinae

Hypostominae

Heptapteridae

Ictaluridae

Auchenipteridae

Clariidae

Pimelodidae 


\section{FAMÍLIA}

\section{Trichomycteridae}

Composta por 41 gêneros, no entanto apenas Trichomycterus é encontrado na bacia do rio Iguaçu. Além do pequeno porte, esse grupo de peixes caracteriza-se por apresentar vários odontódeos no opérculo e interopérculo, dois pares de barbilhões na boca (maxilares e rictais) e um par nasal em algumas subfamílias, a nadadeira dorsal é disposta na região posterior ao meio do corpo e não apresentam nadadeira adiposa (DE PINNA; WOSIACKI, 2003). Na bacia do rio Iguaçu, encontram-se 10 espécies descritas do gênero Trichomycterus, das quais nove ocorrem no baixo rio Iguaçu, além de duas ainda não descritas. Em comparação com congêneres que ocorrem em outras bacias, algumas espécies de Trichomycterus do rio Iguaçu apresentam um formato do corpo peculiar, com o pedúnculo caudal muito alto, bem mais alto do que a cabeça, e porte relativamente maior.

\section{Chave para espécies de Trichomycterus}

1. Nadadeira caudal bifurcada nos adultos; pedúnculo caudal muito alto, sua altura contida menos de 5 vezes no comprimento padrão ...... T. crassicaudatus

1'. Nadadeira caudal truncada; pedúnculo caudal baixo, sua altura contida mais de cinco vezes no comprimento padrão

2. Borda da nadadeira caudal com uma faixa escura ......................................... . castroi

2'. Borda da nadadeira caudal sem faixa escura .................................................................. 3

3. Corpo de coloração uniforme, sem manchas .................................................................. 4

3'. Corpo com manchas cinza-escuras ou castanhas distribuídas pelo flanco ....... 5

4. Região ventral da cabeça com papilas ..................................................... T. papilliferus

4'. Região ventral da cabeça sem papilas ..................................................... T. plumbeus

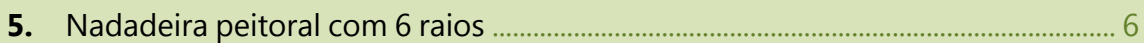

5'. Nadadeira peitoral com mais de 6 raios .............................................................................. 7

6. Primeiro raio da nadadeira peitoral com pequeno prolongamento; cabeça curta, seu comprimento contido mais de 5,2 vezes no comprimento padrão; pintas castanho-escuras bem evidentes sobre o corpo ....... T. taroba

6'. Primeiro raio da nadadeira peitoral sem prolongamento; cabeça longa, seu comprimento contido 5,2 vezes ou menos no comprimento padrão; pintas castanhas difusas sobre o corpo ……...................................... T. mboycy

7. Cabeça longa, seu comprimento contido 4,2 vezes ou menos no comprimento padrão; nadadeira peitoral com 8 raios .................................................. T. igobi

7'. Cabeça curta, seu comprimento contido 4,2 vezes ou mais no comprimento padrão; nadadeira peitoral com 7 raios

8. Primeiro raio da nadadeira peitoral com pequeno prolongamento Trichomycterus sp. 1

8'. Primeiro raio da nadadeira peitoral sem prolongamento

9. Pintas e manchas cinza-escuras formando uma faixa escura no flanco Trichomycterus sp. 2

9'. Pintas e/ou manchas castanho-escuras no flanco, mas nunca formando uma faixa

10. Pintas e pequenas manchas castanhas ou cinza-escuras presentes no flanco, mas não sobrepostas

10'. Manchas castanhas ou cinza-escuras grandes e pequenas, unidas ou sobrepostas no flanco T. stawiarski 
- Trichomycterus castroi de Pinna, 1992

Candiru

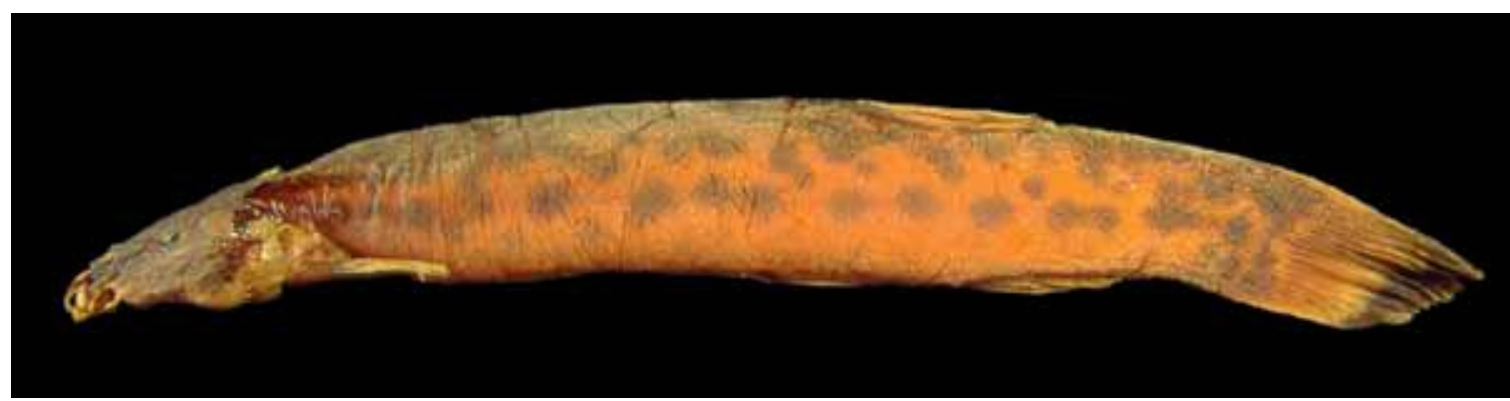

Comprimento padrão 102,8 mm

Corpo amarelado, mais claro na região ventral, manchas castanhas ou cinza-escuras irregulares distribuídas sobre o tronco, exceto na região ventral. Nadadeiras com pintas cinza-escuras, mais concentradas em suas bases, exceto a caudal, amarelada e com poucos pigmentos escuros na base, seguida por uma faixa mais clara adjacente a uma faixa preta e larga na borda. Corpo alongado, deprimido na região da cabeça, arredondado na região anterior do tronco e comprimido na região posterior. Cabeça mais larga que o tronco, boca subterminal e barbilhões largos próximo à base, estreitando em direção às extremidades. Origem da nadadeira dorsal posterior à vertical que passa pela origem da nadadeira pélvica, nadadeira caudal truncada.

Altura do corpo contida 5,9 a $7,7^{*}$, do pedúnculo caudal 7,1 a $8,3^{*}$ e comprimento da cabeça 5,0 a 5,6* vezes no CP. Comprimento dos barbilhões nasal 2,2 a 3,1*, maxilar 2,1 a $2,9^{*}$ e rictal contido 2,5 a 3,0*, do focinho 2,0 a 2,1*, diâmetro orbital 9,7 a $10,2^{*} \mathrm{e}$ distância interorbital 3,4 a 4,0* vezes no CC.

Nadadeira dorsal com $9^{*}$ raios, peitoral com $8^{*}$, pélvica com $5^{\star}$ e anal com $7^{\star}$ raios.

Geralmente associada a substratos rochosos, sua distribuição geográfica é aparentemente restrita à bacia hidrográfica do rio Iguaçu.

\footnotetext{
*de Pinna (1992)
}

\section{- Trichomycterus crassicaudatus Wosiacki \& de Pinna, 2008 \\ Candiru}

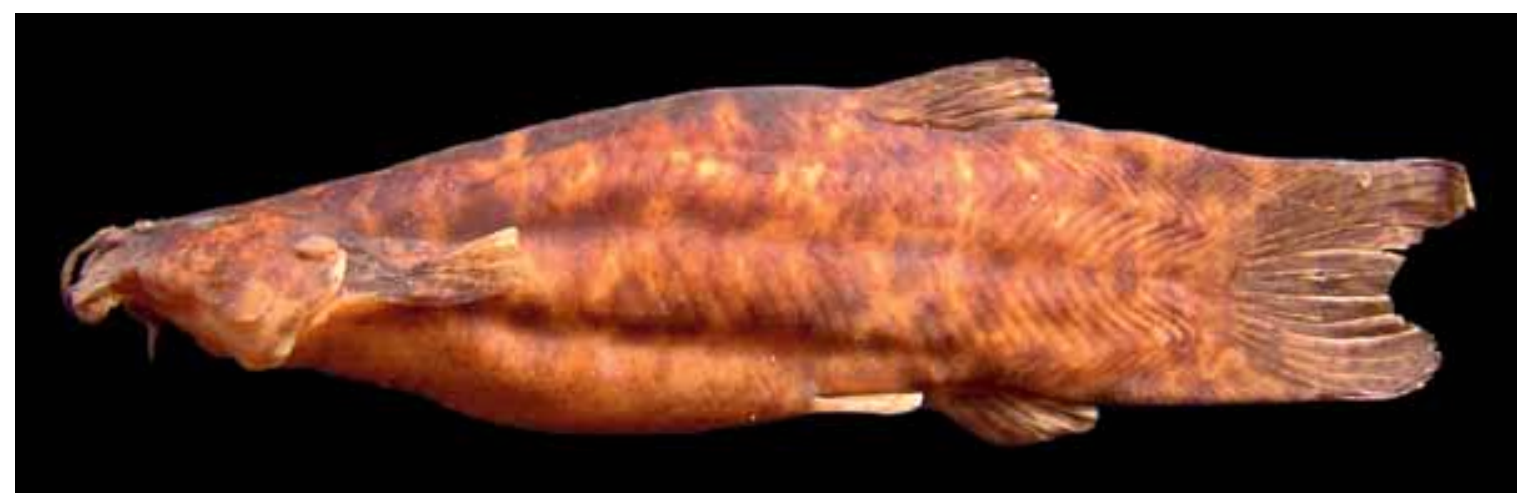

Comprimento padrão 97,5mm 


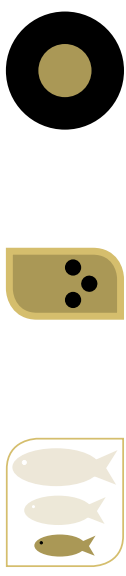

Corpo amarelado, clareando na região ventral, manchas castanhas ou cinza-escuras irregulares distribuídas pelo corpo, exceto na região ventral. Nadadeiras com pintas cinza-escuras. Corpo alongado, deprimido na região da cabeça, arredondado na região anterior do tronco e comprimido na região posterior. Cabeça mais larga que o tronco, boca subterminal e barbilhões largos próximo à base, estreitando em direção às extremidades. Origem da nadadeira dorsal posterior à vertical que passa pela origem da nadadeira pélvica, nadadeira caudal bifurcada nos adultos.

Altura do corpo contida 3,4 a 4,0*, do pedúnculo caudal 3,9 a 4,4* e comprimento da cabeça 4,2 a $4,7^{*}$ vezes no CP. Comprimento dos barbilhões nasal 2,4 a 3,0*, maxilar 2,5 a $3,6^{*}$ e rictal contido 2,5 a $3,9^{*}$, do focinho 1,8 a $2,3^{*}$, diâmetro orbital 10,3 a $12,5^{*}$ e distância interorbital 3,2 a 4,5* vezes no CC.

Nadadeira dorsal com $9^{*}$ raios, peitoral com $8^{\star}$, pélvica com $5^{\star}$ e anal com $7^{*}$ raios.

Geralmente associada a substratos rochosos, esta espécie apresenta distribuição geográfica restrita à sub-bacia do rio Jordão, afluente do baixo rio Iguaçu.

*Wosiacki e de Pinna (2008a)

\section{- Trichomycterus davisi (Haseman, 1911) Candiru}

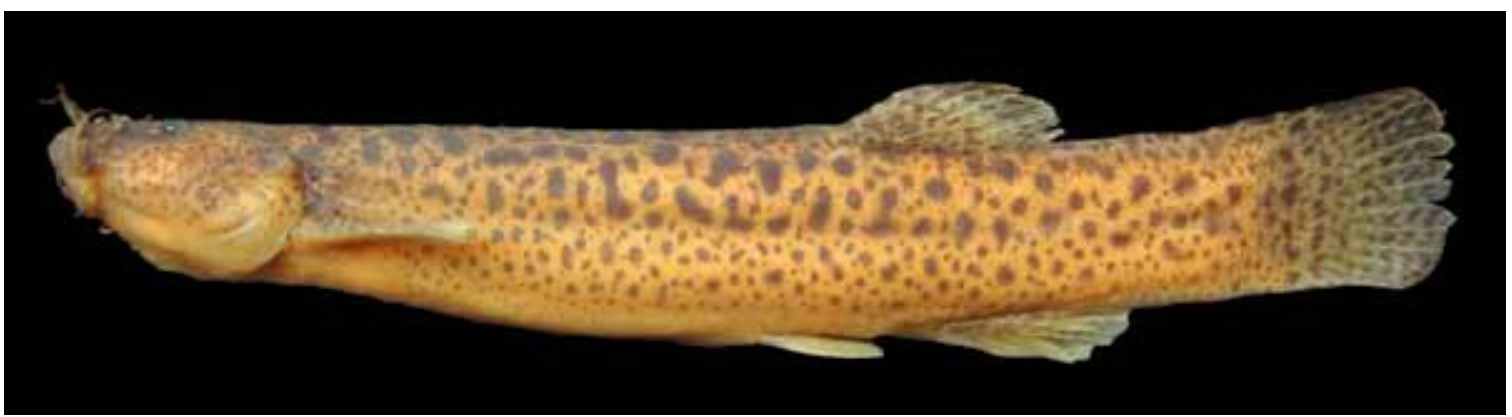

Comprimento padrão 83,1 mm

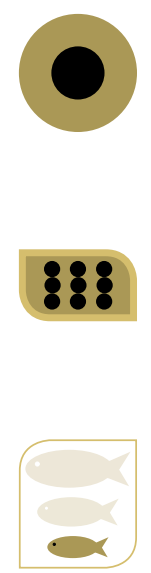

Corpo amarelado, clareando na região ventral, manchas castanhas ou cinza-escuras irregulares distribuídas pelo corpo, exceto na região ventral. Nadadeiras com pintas cinza-escuras. Corpo alongado, deprimido na região da cabeça, arredondado na região anterior do tronco e comprimido na região posterior. Cabeça mais larga que o tronco, boca subterminal e barbilhões largos próximo à base, estreitando em direção às extremidades. Origem da nadadeira dorsal posterior à vertical que passa pela origem da nadadeira pélvica, nadadeira caudal truncada.

Altura do corpo contida 5,2 a 8,2*, do pedúnculo caudal 6,3 a $11,0^{*}$ e comprimento da cabeça 4,2 a 7,6* vezes no CP. Comprimento dos barbilhões nasal 0,9 a 2,8*, maxilar 0,9 a $2,7^{*}$ e rictal contido 0,9 a $2,6^{*}$, do focinho 1,4 a $5,1^{*}$, diâmetro orbital 5,1 a $18,0 *$ e distância interorbital 2,3 a $8,9 *$ vezes no CC.

Nadadeira dorsal com 9* raios, peitoral com 7*, pélvica com 5* e anal com 6 ou 7* raios.

Esta espécie distribui-se geograficamente em rios das bacias do Iguaçu e Ribeira de Iguape (WOSIACKI; DE PINNA, 2007). 
- Trichomycterus igobi Wosiacki \& de Pinna, 2008

Candiru

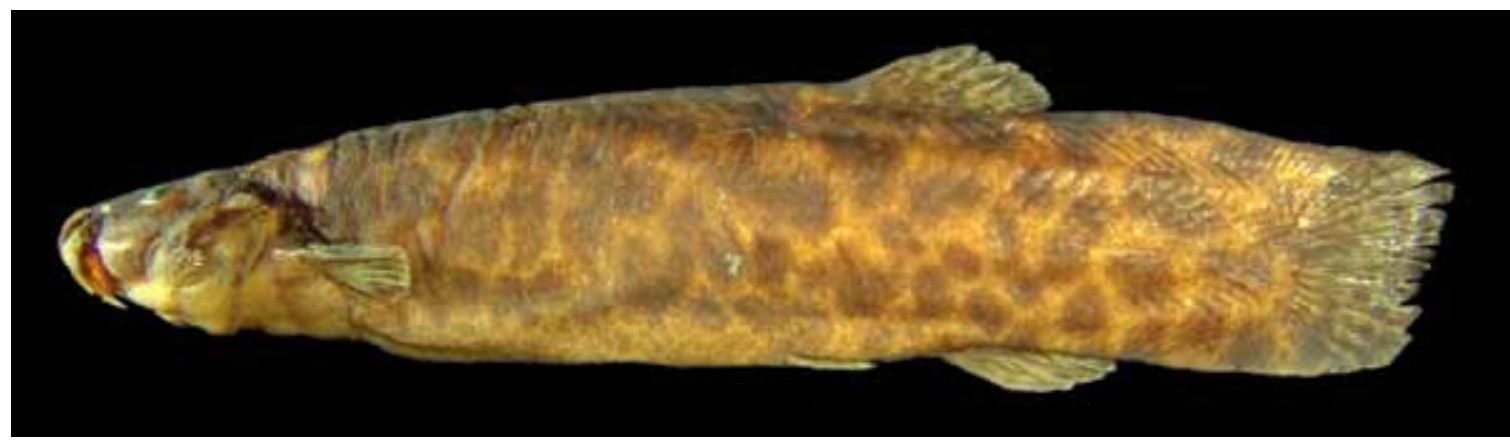

Comprimento padrão 125,9 mm

Corpo amarelado, mais claro na região ventral, manchas castanhas ou cinza-escuras irregulares distribuídas sobre o corpo, exceto na região ventral. Nadadeiras com pintas cinza-escuras, mais concentradas em suas bases. Corpo alongado, deprimido na região da cabeça, arredondado na região anterior do tronco e comprimido na região posterior. Cabeça mais larga que o tronco, boca subterminal e barbilhões largos próximo à base, estreitando em direção às extremidades. Origem da nadadeira dorsal posterior à vertical que passa pela origem da nadadeira pélvica, nadadeira caudal truncada.

Altura do corpo contida 4,0 a 5,8* do pedúnculo caudal 5,3 a 6,3* e comprimento da cabeça 3,7 a 4,2* vezes no CP. Comprimento dos barbilhões nasal 2,4 a $3,3^{*}$, maxilar 2,3 a $3,6^{*}$ e rictal contido 2,3 a 3,6*, do focinho 1,9 a 2,6*, diâmetro orbital 7,5 a $11,1^{*}$ e distância interorbital 3,3 a 4,8* vezes no CC.

Nadadeira dorsal com 7 ou $8^{*}$ raios, peitoral com $8^{*}$, pélvica com $5^{\star}$ e anal com 6 ou $7^{*}$ raios.

Geralmente associada a substratos rochosos, esta espécie apresenta distribuição geográfica restrita à sub-bacia do rio Jordão, afluente do baixo rio Iguaçu.

*Wosiacki e de Pinna (2008b) 
- Trichomycterus mboycy Wosiacki \& Garavello, 2004

Candiru

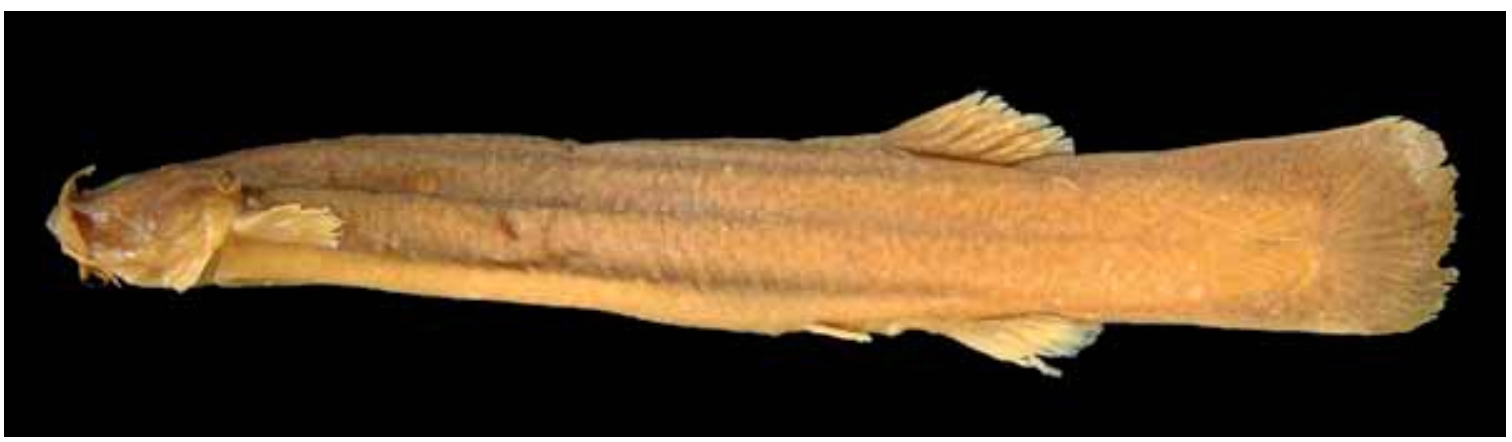

Comprimento padrão 125,7 mm

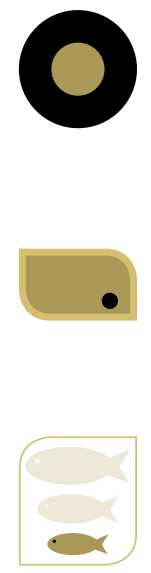

Corpo marrom amarelado, mais claro na região ventral, pintas castanhas ou cinza-escuras irregulares distribuídas pelo tronco, exceto na região ventral. Nadadeiras dorsal e anal com pintas cinza-escuras, peitoral com poucos pigmentos escuros e pélvica sem pigmentação. Corpo alongado, deprimido na região da cabeça, arredondado na região anterior do tronco e comprimido na região posterior. Cabeça mais larga que o corpo, boca subterminal e barbilhões largos próximo à base, estreitando em direção às extremidades. Origem da nadadeira dorsal posterior à vertical que passa pela origem da nadadeira pélvica, nadadeira caudal truncada ou arredondada.

Altura do corpo contida 6,3 a 7,4*, do pedúnculo caudal 7,4 a $8,1^{*}$ e comprimento da cabeça 5,3 a 6,2* vezes no CP. Comprimento dos barbilhões nasal 1,6 a 2,4*, maxilar 1,6 a $2,0^{*}$ e rictal contido 1,7 a $2,4^{*}$, do focinho contido 2,2 a 2,5*, diâmetro orbital 6,7 a $15,4^{*}$ e distância interorbital 3,6 a 4,5* vezes no CC.

Nadadeira dorsal com 9* raios, peitoral com 6*, pélvica com 5* e anal com $7^{*}$ raios.

Geralmente associada a substratos rochosos, sua distribuição geográfica é aparentemente restrita à bacia hidrográfica do rio Iguaçu.

*Wosiacki e Garavello (2004) 
- Trichomycterus papilliferus Wosiacki \& Garavello, 2004

Candiru

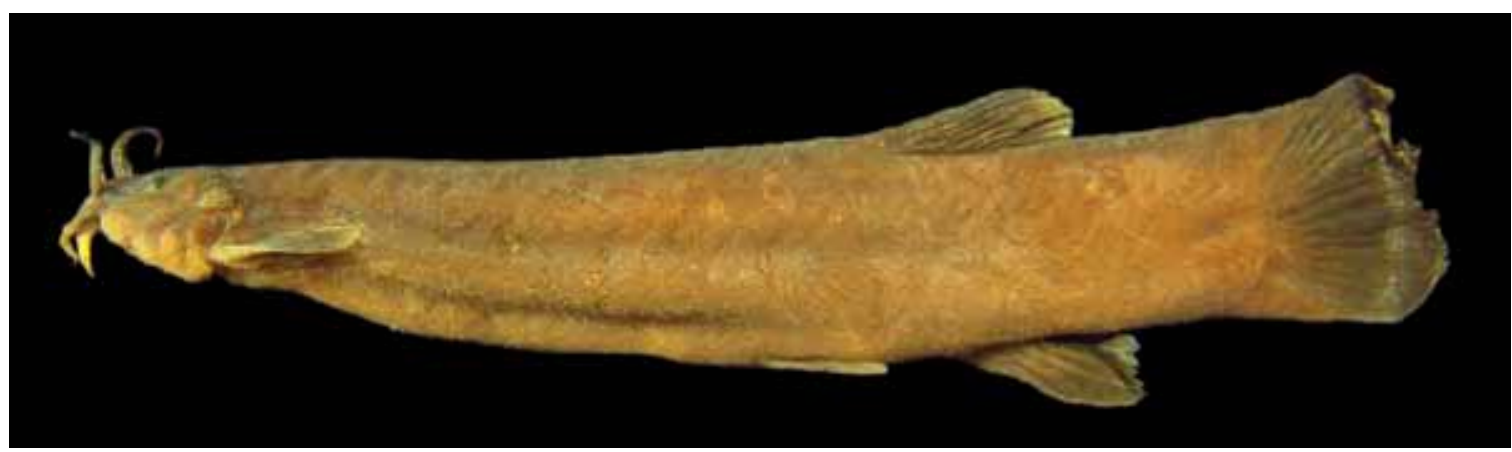

Comprimento padrão 101,1 mm

Corpo castanho, mais claro na região ventral da cabeça. Nadadeiras marrom-escuras. Corpo alongado, deprimido na região da cabeça, arredondado na região anterior do tronco e comprimido na região posterior. Cabeça com papilas desenvolvidas na região ventral, boca subterminal e barbilhões largos próximo à base, estreitando em direção às extremidades. Origem da nadadeira dorsal posterior à vertical que passa pela origem da nadadeira pélvica, nadadeira caudal truncada.

Altura do corpo contida 5,2 a $7,2^{*}$, do pedúnculo caudal 6,0 a 9,2* e comprimento da cabeça 5,1 a $6,4^{*}$ vezes no CP. Comprimento dos barbilhões nasal 1,6 a $3,5^{*}$, maxilar 3,2 a $5,7^{*}$ e rictal contido 3,4 a $8,2^{*}$, do focinho 2,2 a $2,6^{*}$, diâmetro orbital 7,8 a $14,9^{*}$ e distância interorbital 3,5 a 5,2* vezes no CC.

Nadadeira dorsal com $8^{*}$ raios, peitoral com $7^{*}$, pélvica com $5^{\star}$ e anal com $6^{\star}$ raios.

A atividade reprodutiva desta espécie inicia com $\mathrm{CP}=75,0 \mathrm{~mm}$ nos machos e $C P=105,0 \mathrm{~mm}$ nas fêmeas, segundo Suzuki e Agostinho (1997). No reservatório de Segredo, era identificada como Trichomycterus sp. D após Garavello, Pavanelli e Suzuki (1997). Geralmente associada a substratos rochosos, sua distribuição geográfica é aparentemente restrita à bacia hidrográfica do rio Iguaçu.

*Wosiacki e Garavello (2004)

- Trichomycterus plumbeus Wosiacki \& Garavello, 2004 Candiru

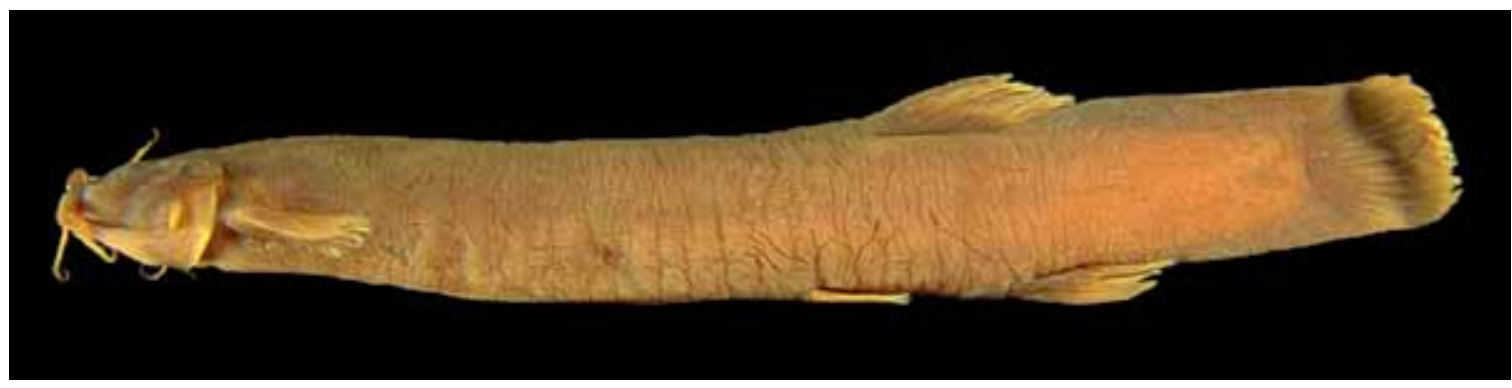

Comprimento padrão 108,6 mm 


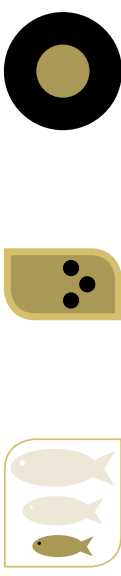

Corpo castanho-escuro, mais claro na região ventral da cabeça. Nadadeiras com pigmentação escura principalmente sobre a base dos seus raios. Corpo alongado, deprimido na região da cabeça, arredondado na região anterior do tronco e comprimido na região posterior. Cabeça mais estreita anteriormente e mais larga posteriormente, boca subterminal e barbilhões largos próximo à base, estreitando em direção às extremidades. Origem da nadadeira dorsal posterior à vertical que passa pela origem da nadadeira pélvica, nadadeira caudal truncada.

Altura do corpo contida 6,1 a $7,9^{*}$, do pedúnculo caudal 6,7 a 9,3* e comprimento da cabeça 4,5 a 5,6* vezes no CP. Comprimento dos barbilhões nasal 1,6 a 2,6*, maxilar 1,2 a $2,2^{*}$ e rictal contido 1,0 a $7,6^{*}$, do focinho 1,8 a $2,5^{*}$, diâmetro orbital 6,4 a $19,2^{*}$ e distância interorbital 4,0 a 5,7* vezes no CC.

Nadadeira dorsal com $9^{\star}$ raios, peitoral com 7 ou $8^{*}$, pélvica com $5^{\star}$ e anal com $7^{*}$ raios.

Geralmente associada a substratos rochosos, esta espécie apresenta distribuição geográfica restrita à sub-bacia do rio Jordão, afluente do baixo rio Iguaçu.

*Wosiacki e Garavello (2004)

\section{- Trichomycterus stawiarski (Miranda Ribeiro, 1968) Candiru}

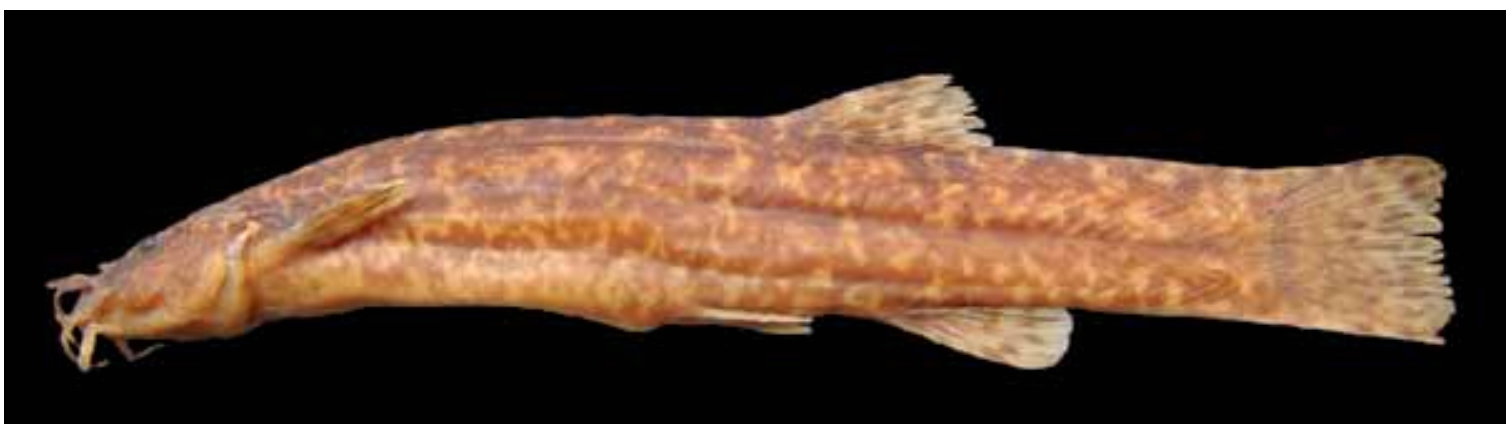

Comprimento padrão $66,6 \mathrm{~mm}$
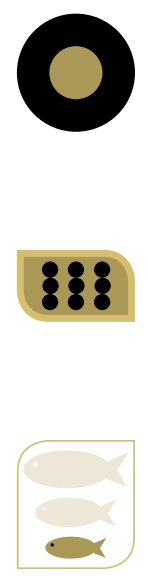

Corpo marrom amarelado, mais claro na região ventral, manchas castanho-escuras irregulares distribuídas pelo corpo, exceto na região ventral. Nadadeiras com pintas castanho-escuras. Corpo alongado, deprimido na região da cabeça, arredondado na região anterior do tronco e comprimido na região posterior. Cabeça mais larga que o corpo, boca subterminal e barbilhões largos próximo à base, estreitando em direção às extremidades. Origem da nadadeira dorsal posterior à vertical que passa pela origem da nadadeira pélvica, nadadeira caudal truncada.

Altura do corpo contida 5,4 a $7,3^{*}$, do pedúnculo caudal 6,9 a $9,4^{*}$ e comprimento da cabeça 4,4 a 5,6* vezes no CP. Comprimento dos barbilhões nasal 1,7 a 4,6*, maxilar 1,6 a $3,5^{*}$ e rictal contido 1,6 a 3,6*, do focinho 2,1 a 3,3*, diâmetro orbital 4,5 a 9,1* e distância interorbital 3,9 a 6,5* vezes no CC.

Nadadeira dorsal com 8 ou $9 *$ raios, peitoral com $7^{*}$, pélvica com $5^{*}$ e anal com 6 a $8 *$ raios.

Geralmente associada a substratos rochosos, esta espécie apresenta distribuição geográfica restrita à bacia do rio Iguaçu.

*Wosiacki (1997) 


\section{- Trichomycterus taroba Wosiacki \& Garavello, 2004}

Candiru

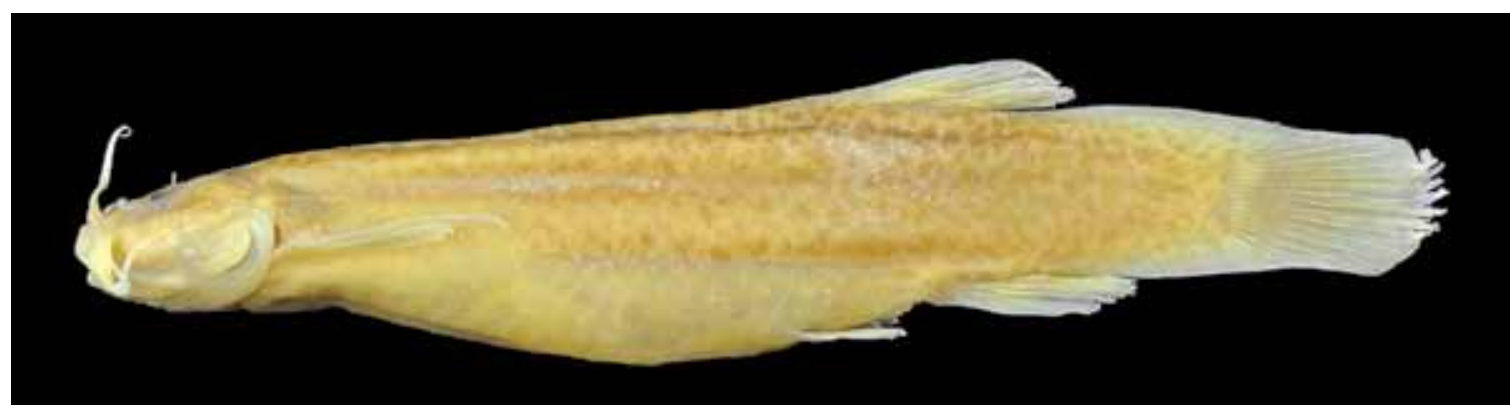

Comprimento padrão 52,0 mm

Corpo amarelado, mais claro na região ventral, pintas e manchas castanho-escuras irregulares distribuídas pelo corpo, exceto na região ventral. Nadadeiras hialinas, com pigmentos escuros próximo à base, às vezes formando pintas. Corpo alongado, deprimido na região da cabeça, arredondado na região anterior do tronco e comprimido na região posterior. Cabeça mais larga que o corpo, boca subterminal e barbilhões largos próximo à base, estreitando em direção às extremidades. Origem da nadadeira dorsal posterior à vertical que passa pela origem da nadadeira pélvica, nadadeira peitoral com leve prolongamento no primeiro raio e nadadeira caudal truncada.

Altura do corpo contida 4,3 a $6,0^{*}$, do pedúnculo caudal 6,1 a $8,5^{*}$ e comprimento da cabeça 4,5 a $5,2^{*}$ vezes no $C P$. Comprimento dos barbilhões nasal 1,0 a $2,2^{*}$, maxilar 1,0 a $3,2^{*}$ e rictal contido 1,0 a $2,7^{*}$, do focinho 1,8 a $2,7^{*}$, diâmetro orbital 6,1 a $13,3^{*} \mathrm{e}$ distância interorbital 2,6 a 4,0* vezes no CC.

Nadadeira dorsal com $9^{*}$ raios, peitoral com $6 *$, pélvica com $5^{*}$ e anal com 7 ou $8^{*}$ raios.

Geralmente associada a substratos rochosos, esta espécie apresenta distribuição geográfica restrita à bacia do baixo rio Iguaçu.

*Wosiacki e Garavello (2004) 


\section{- Trichomycterus sp. 1 \\ Candiru}

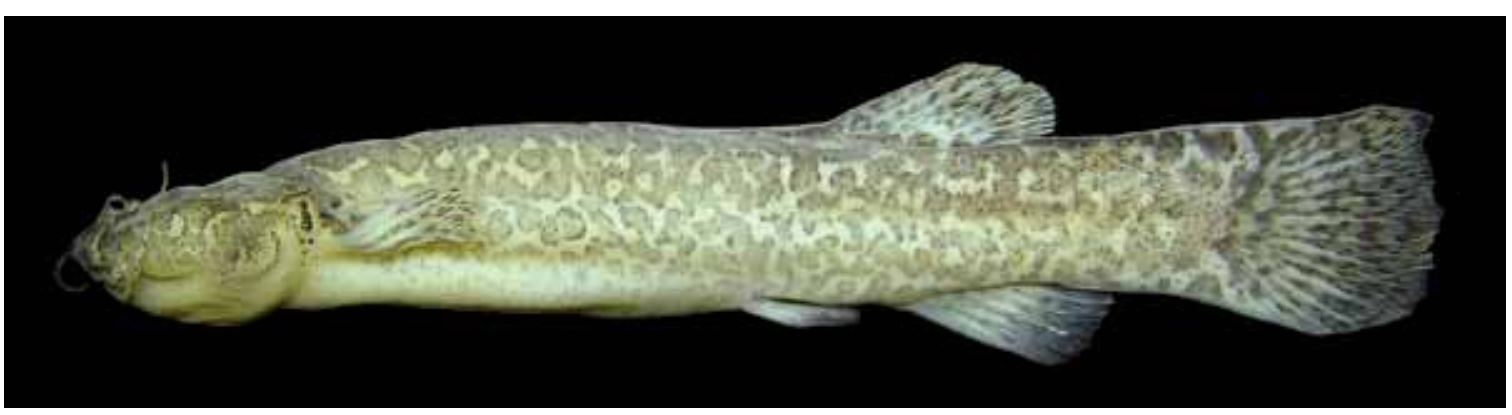

Comprimento padrão $62,1 \mathrm{~mm}$

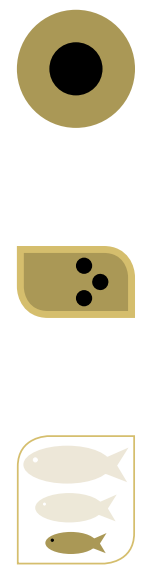

Corpo cinza amarelado, mais claro na região ventral, manchas cinza escuras irregulares distribuídas pelo corpo, exceto na região ventral, formando faixas claras irregulares em indivíduos maiores. Nadadeiras com pintas castanho escuras. Corpo alongado, deprimido na região da cabeça, arredondado na região anterior do tronco e comprimido na região posterior. Cabeça mais larga que o corpo, boca subterminal e barbilhões largos próximo à base, estreitando em direção às extremidades. Origem da nadadeira dorsal posterior à vertical que passa pela origem da nadadeira pélvica, nadadeira peitoral com leve prolongamento no primeiro raio, nadadeira caudal truncada.

Altura do corpo contida 5,5 a 6,1, do pedúnculo caudal 7,2 a 7,6 e comprimento da cabeça 4,4 a 4,9 vezes no CP. Comprimento dos barbilhões nasal 1,3 a 1,4, maxilar 1,1 a 1,3 e rictal contido 1,4 a 1,5 , do focinho 2,3 a 2,7, diâmetro orbital 7,5 a 8,3 e distância interorbital 4,0 a 4,2 vezes no CC.

Nadadeira dorsal com 8 ou 9 raios, peitoral com 7, pélvica com 5 e anal com 8 raios.

Geralmente associada a substratos rochosos, há registro de indivíduos similares na bacia do alto rio Paraná. Sua ocorrência no rio Iguaçu foi registrada abaixo do reservatório de Salto Caxias. 


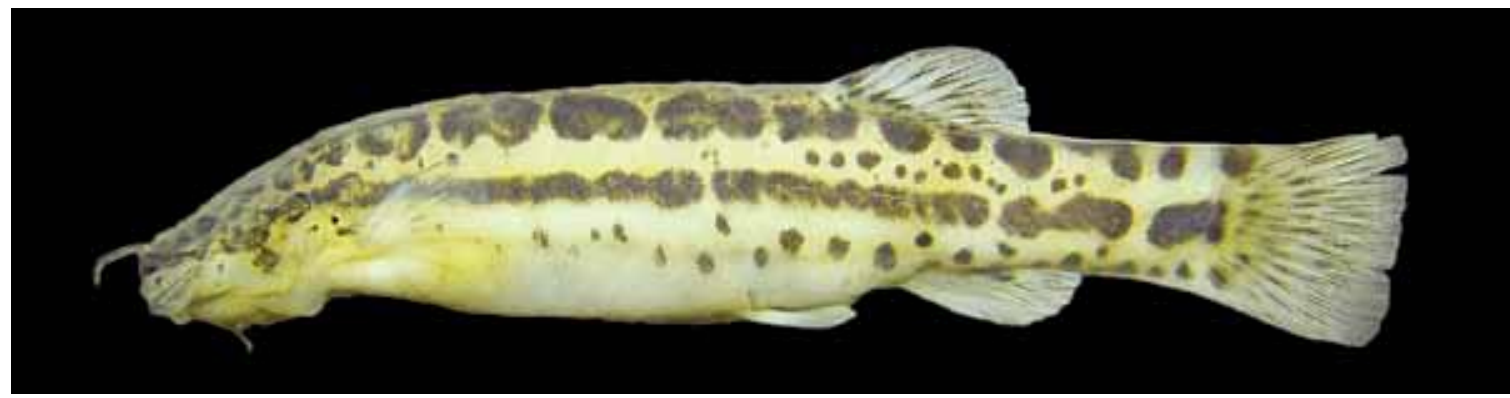

Comprimento padrão 39,5 mm

Corpo amarelado, mais claro na região ventral, manchas castanho-escuras irregulares distribuídas pelo corpo, exceto na região ventral, faixa longitudinal escura irregular no flanco. Nadadeiras hialinas, com pigmentos escuros próximo à base, às vezes formando pintas. Corpo alongado, deprimido na região da cabeça, arredondado na região anterior do tronco e comprimido na região posterior. Cabeça mais larga que o corpo, boca subterminal e barbilhões largos próximo à base, estreitando em direção às extremidades. Origem da nadadeira dorsal posterior à vertical que passa pela origem da nadadeira pélvica e nadadeira caudal truncada.

Altura do corpo contida 4,6 a 5,0, do pedúnculo caudal 7,9 a 8,1 e comprimento da cabeça 4,6 a 5,0 vezes no CP. Comprimento dos barbilhões nasal 1,5 a 1,7 , maxilar 1,4 a 1,7 e rictal contido 1,6 a 2,0, do focinho 2,3 a 2,6, diâmetro orbital 6,8 a 8,5 e distância interorbital 4,0 a 4,6 vezes no CC.

Nadadeira dorsal com 8 ou 9 raios, peitoral com 7, pélvica com 5 e anal com 7 ou 8 raios.

Geralmente associada a substratos rochosos, há registro de indivíduos similares na bacia do alto rio Paraná. Sua ocorrência no rio Iguaçu foi registrada abaixo do reservatório de Salto Caxias. 


\section{FAMÍLIA}

\section{Callichthyidae}

Esta família é caracterizada por apresentar espécies com duas séries de placas na lateral do corpo, linha lateral reduzida, osso antiorbital lacrimal ausente, séries infraorbital reduzidas para dois ossos e dentes pré-maxilares ausentes nos adultos. Uma importante característica dos indivíduos dessa família é a presença de órgão acessório à respiração, localizado no intestino, o que lhes dá condição de sobrevivência em situação de anoxia (REIS, 2003). Entre as espécies que compõem esta família, no baixo rio Iguaçu, são encontradas três nativas, Corydoras carlae, $C$. ehrhardti e $C$. aff. paleatus, e duas espécies não nativas, Callichthys callichthys e Hoplosternum littorale.

- Callichthys callichthys (Linnaeus, 1758)

Tamboatá, caboja

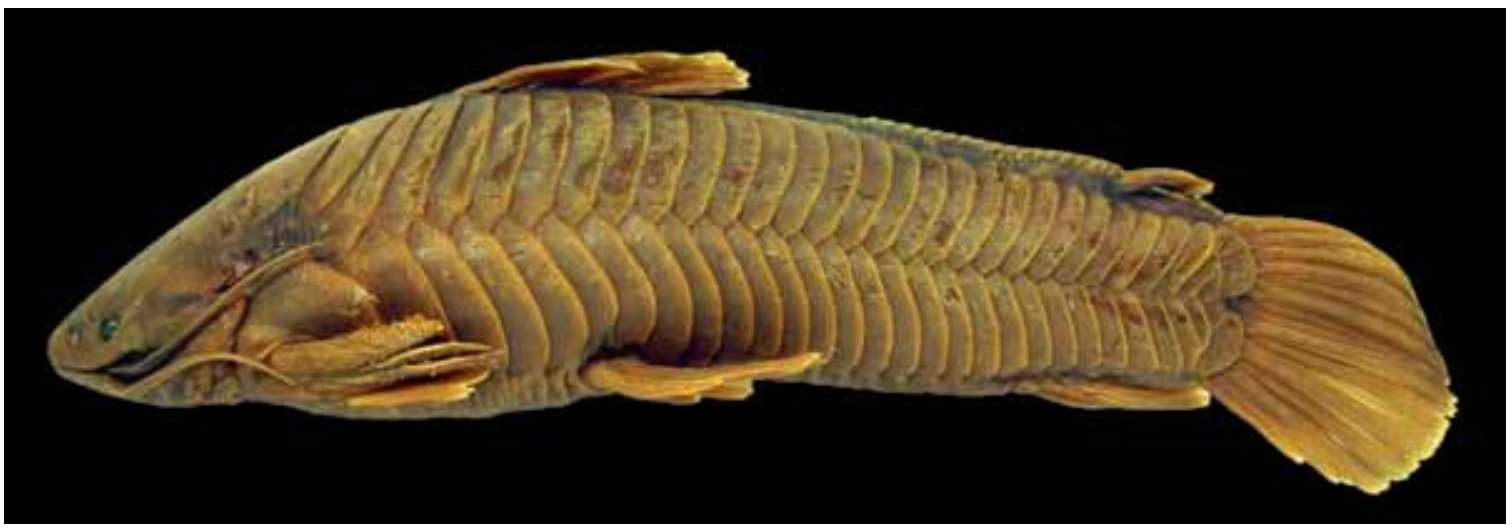

Comprimento padrão $87,6 \mathrm{~mm}$

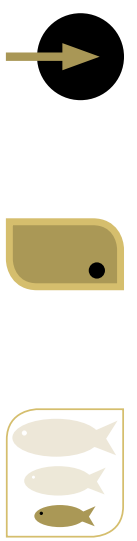

Corpo cinza-escuro, pouco mais claro na região ventral, nadadeiras com pigmentos escuros dispersos, principalmente sobre os raios. Corpo alongado e coberto por duas séries de placas laterais altas, as quais são ausentes na região abdominal. Boca terminal. Ossos coracoides cobertos por uma pele espessa, barbilhões relativamente longos e nadadeira caudal truncada.

Altura do corpo contida 3,9 a 5,5, do pedúnculo caudal 5,7 a 7,1 e comprimento da cabeça 3,6 a 4,2 vezes no CP. Comprimento do focinho contido 2,1 a 2,4, do acúleo dorsal 1,4 a 1,9, diâmetro orbital 8,7 a 10,8 e distância interorbital 1,4 a 1,6 vezes no CC.

Nadadeira dorsal com $\mathrm{I}+7$ raios, peitoral com $\mathrm{I}+7$, pélvica e anal com 6 raios. Possui 28 a 30 placas dérmicas na série lateral superior, 26 a 27 na inferior e linha lateral incompleta, com 3 poros na série lateral superior.

Esta espécie possui ampla distribuição geográfica, sendo encontrada nas bacias hidrográficas dos rios Amazonas, Araguaia, Paraguai, Uruguai, Madeira, São Francisco, Paraná e bacias costeiras do sul e do sudeste (BRITTO, 2007). Provavelmente tenha sido introduzida na bacia do rio Iguaçu, por ser utilizada por alguns pescadores como isca viva. Na planície de inundação do alto rio Paraná, esta espécie é encontrada em riachos, lagoas e canais, e alimenta-se de pequenos peixes, insetos e vegetais (HAHN; FUGI; ANDRIAN, 2004). 
1. Nadadeiras com coloração uniforme, sem pintas ou manchas C. ehrhardti

1'. Nadadeiras com pintas pretas ou castanho-escuras

2. Lateral do corpo com muitas pintas e algumas manchas castanho-escuras, irregulares; nadadeira dorsal castanho-escura distalmente

C. carlae

2'. Lateral do corpo com três grandes manchas pretas ou castanho-escuras bem definidas e outras manchas menores, mas sem pintas pulverizadas entre as manchas; nadadeira dorsal com pintas castanho-escuras pequenas e difusas, às vezes unidas, formando faixas irregulares C. aff. paleatus

- Corydoras carlae Nijssen \& Isbrücker, 1983

Coridoras, limpa-vidro

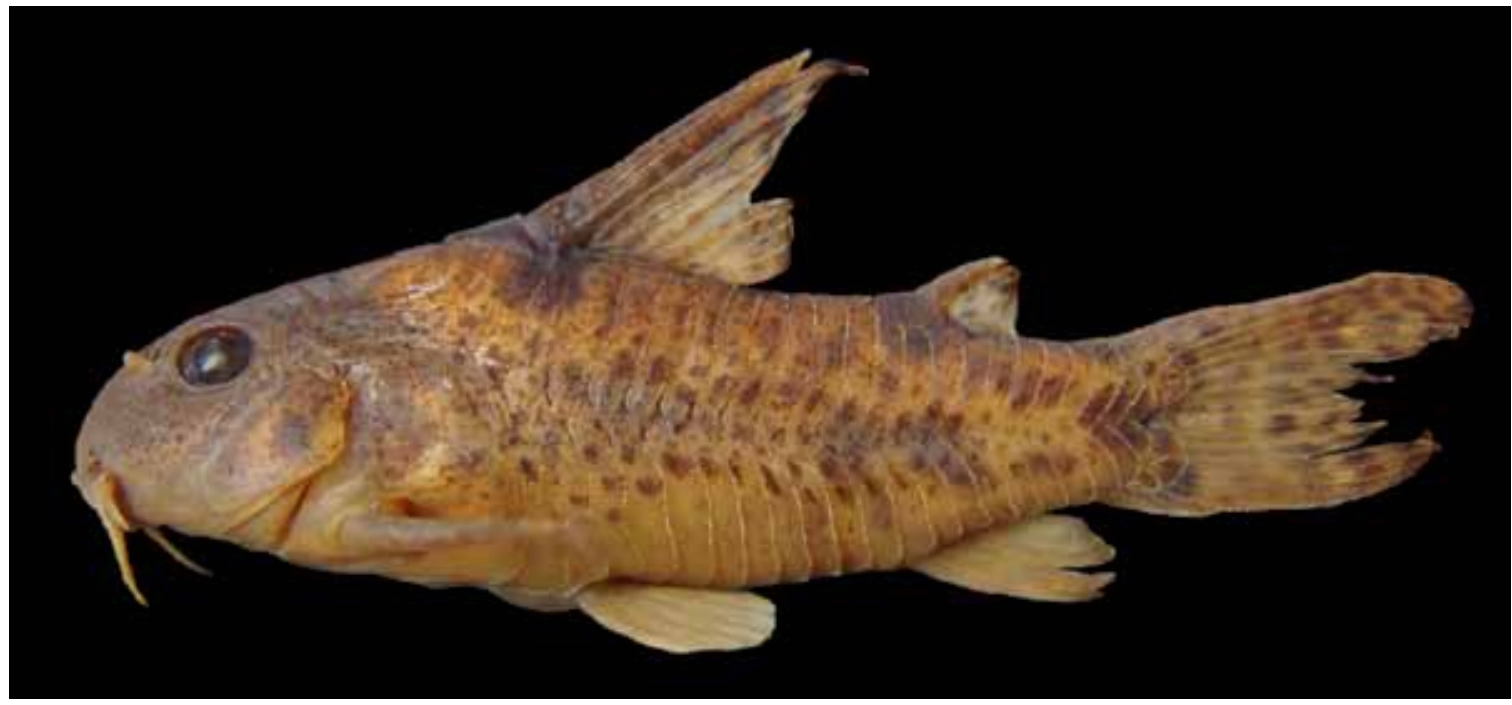

Comprimento padrão 48,8 mm

Corpo amarelado, com manchas castanho-escuras irregulares distribuídas por todo o corpo, uma mancha preta evidente na origem das nadadeiras dorsal e adiposa. Nadadeiras com pequenas pintas castanhas dispersas, às vezes formando faixas na caudal. Corpo curto e coberto por duas séries de placas laterais altas, boca subterminal. Ossos do coracoide expostos, barbilhões relativamente curtos e nadadeira caudal bifurcada.

Altura do corpo contida 2,7 a 3,0, do pedúnculo caudal 6,7 a 7,8 e comprimento da cabeça 3,2 a 3,5 vezes no CP. Comprimento do focinho contido 2,0 a 2,4, do acúleo dorsal 0,9 a 1,1, diâmetro orbital 3,3 a 3,7 e distância interorbital 2,7 a 3,0 vezes no CC.

Nadadeira dorsal com I+7 ou 8 raios, peitoral com I+7 ou 8, pélvica com 6 e anal com 6 ou 7 raios. Possui 23 a 24 placas dérmicas na série lateral superior e 20 a 22 na inferior e linha lateral incompleta, com 3 ou 4 poros na série lateral superior.

Esta espécie apresenta distribuição geográfica restrita à bacia hidrográfica do rio Iguaçu (BRITTO, 2007). 


\section{- Corydoras ehrhardti Steindachner, 1910 \\ Coridoras, limpa-vidro}

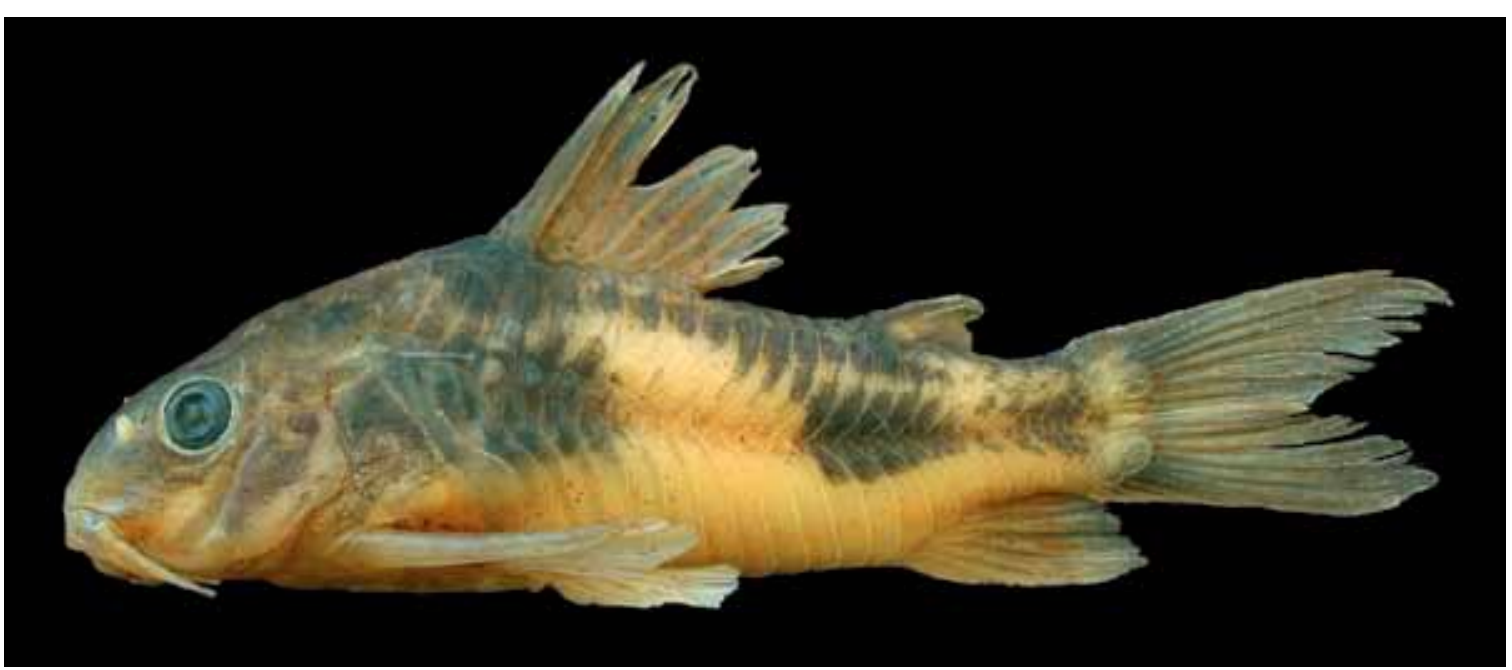

Comprimento padrão 53,6 mm

Corpo amarelado, com três grandes manchas pretas laterais irregulares, uma logo após o opérculo, uma abaixo da nadadeira adiposa e outra menor e mais difusa sobre o pedúnculo caudal. Região dorsal com uma mancha preta evidente na origem das nadadeiras dorsal e adiposa e nadadeiras com pigmentação escura dispersa, não formando pintas nem listras. Corpo curto e coberto por duas séries de placas laterais altas, boca subterminal. Ossos do coracoide expostos, barbilhões relativamente curtos e nadadeira caudal bifurcada.

Altura do corpo contida 2,8 a 3,2, do pedúnculo caudal 7,4 a 8,3 e comprimento da cabeça 3,2 a 3,6 vezes no CP. Comprimento do focinho contido 1,8 a 2,2, do acúleo dorsal 1,1 a 1,6, diâmetro orbital 3,3 a 3,7 e distância interorbital 2,1 a 2,4 vezes no CC.

Nadadeira dorsal com I+7 ou 8 raios, peitoral com I+7, pélvica com 6 e anal com 6 ou 7 raios. Possui 23 ou 24 placas dérmicas na série lateral superior e 20 ou 21 na inferior e linha lateral incompleta, com 3 ou 4 poros na série lateral superior.

Essa espécie é encontrada nos rios Iguaçu, Paranapanema e rios das bacias costeiras, desde o rio Ribeira de Iguape até o rio Itajaí-Mirim (BRITTO, 2007). Ocorre também na bacia do rio Iguaçu onde é facilmente capturada. No capítulo sobre a ictiofauna do reservatório de Segredo, esta espécie foi chamada de Corydoras sp. (GARAVELLO; PAVANELLI; SUZUKI, 1997). 
- Corydoras aff. paleatus (Jenyns, 1842)

Coridoras, limpa-fundo

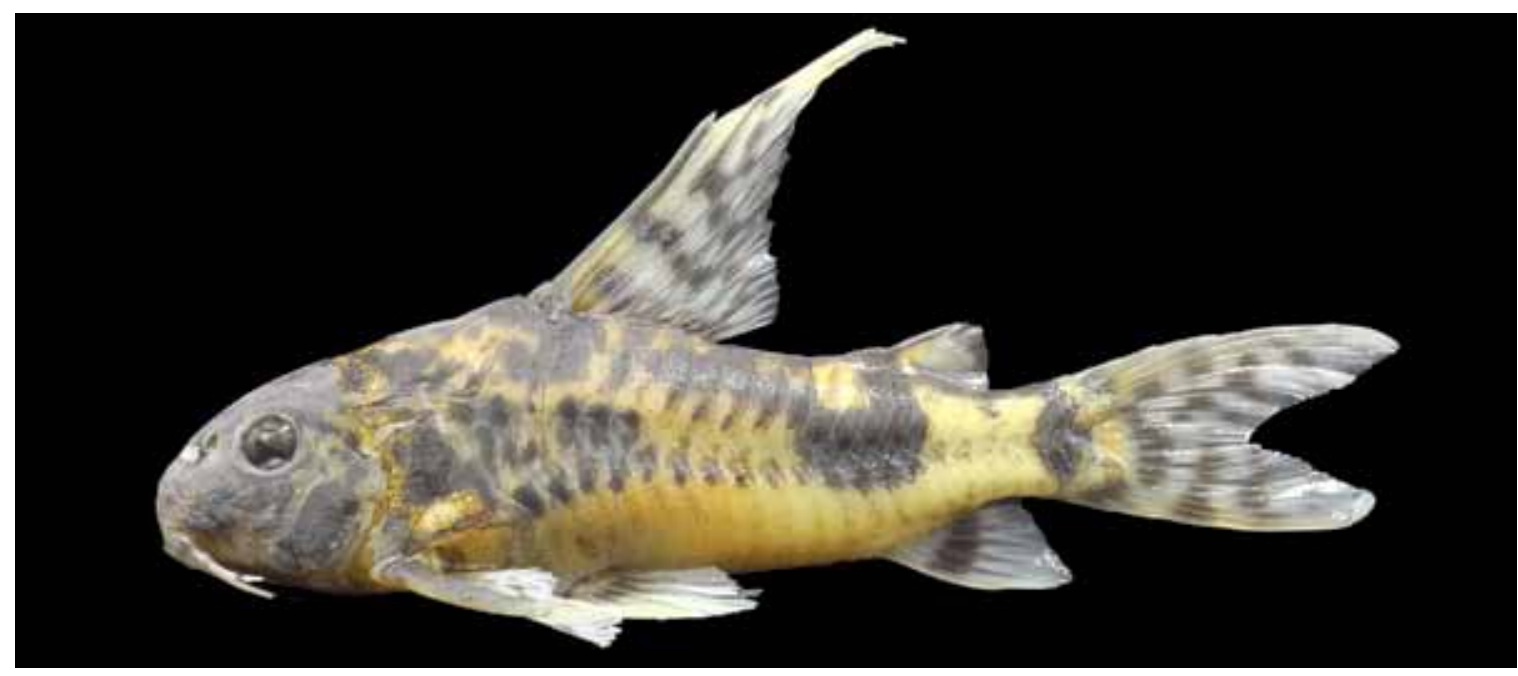

Comprimento padrão 60,0 mm

Corpo amarelado, com três grandes manchas pretas laterais irregulares, uma logo após o opérculo, uma abaixo da nadadeira adiposa e outra menor e mais difusa sobre o pedúnculo caudal. Região dorsal com uma mancha preta evidente na origem das nadadeiras dorsal e adiposa e nadadeiras com pintas pretas, às vezes unidas formando listras, sobretudo na caudal. Corpo curto e coberto por duas séries de placas laterais altas, boca subterminal. Ossos do coracoide expostos, barbilhões relativamente curtos e nadadeira caudal bifurcada.

Altura do corpo contida 2,6 a 3,2, do pedúnculo caudal 7,1 a 8,8 e comprimento da cabeça 2,9 a 3,6 vezes no CP. Comprimento do focinho contido 1,9 a 2,4, do acúleo dorsal 0,8 a 1,4, diâmetro orbital 3,3 a 4,1 e distância interorbital 2,1 a 2,6 vezes no CC.

Nadadeira dorsal com I+7 ou 8 raios, peitoral com I+7 ou 8 , pélvica e anal com 6 raios. Possui 22 a 24 placas dérmicas na série lateral superior e 20 ou 21 na inferior e linha lateral incompleta, com 3 ou 4 poros na série lateral superior.

No reservatório de Segredo esta espécie foi considerada bentófaga, alimentando-se principalmente de insetos e detritos de sedimentos (HAHN; FUGI; ALMEIDA; RUSSO; LOUREIRO, 1997), porém, pode utilizar outros recursos, como microinvertebrados, que no reservatório de Salto Caxias constituíram a base de sua dieta (DELARIVA, 2002). A reprodução ocorre durante $o$ ano todo, com maior intensidade entre julho e setembro (UNIVERSIDADE ESTADUAL DO OESTE DO PARANÁ, 2010). Segundo estes autores, os menores indivíduos em reprodução foram registrados com $C P=42,0 \mathrm{~mm}$ nas fêmeas $\mathrm{e}$ $\mathrm{CP}=45,0 \mathrm{~mm}$ nos machos. Os machos apresentam um prolongamento dos primeiros raios ramificados das nadadeiras dorsal e peitorais. No reservatório de Segredo, as fêmeas têm seu comprimento de primeira maturação a partir de CP=41,0 mm (SUZUKI AGOSTINHO, 1997). Exemplares de C. paleatus são encontrados nas bacias dos rios Uruguai, Paraná e costeiras, desde o rio Itapocu até a Laguna dos Patos (BRITTO, 2007), além da bacia do rio Iguaçu, onde é muito comum. No entanto, há uma suspeita de que as populações atualmente identificadas como $C$. paleatus ao longo destas bacias devam pertencer a um complexo de espécies (SHIBATTA; HOFFMANN, 2005), o qual está sendo estudado por Luiz Tencatt e Carla Pavanelli, por isso a utilização aqui da partícula aff., considerando a espécie do Iguaçu como endêmica e diferente das de outras bacias. 
- Hoplosternum littorale (Hancock, 1828)

Tamboatá, caboja

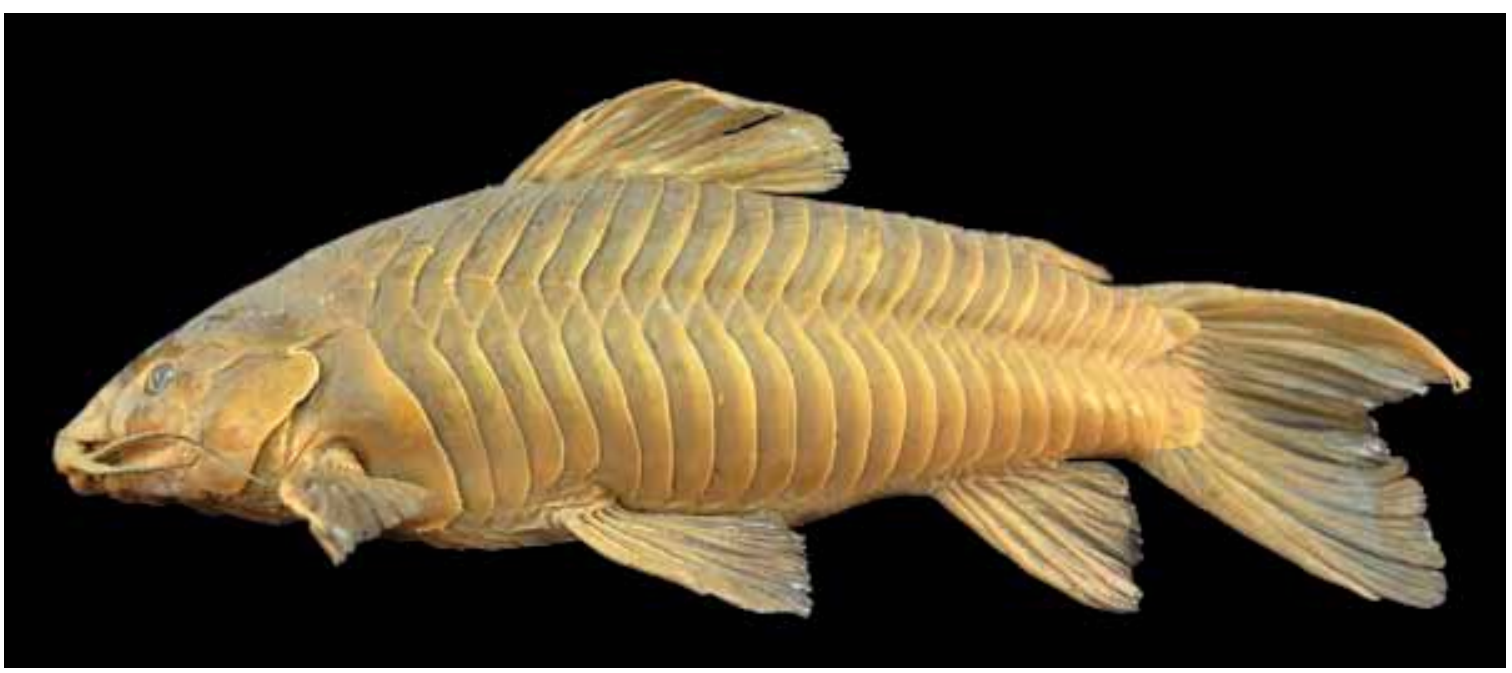

Comprimento padrão $171,0 \mathrm{~mm}$

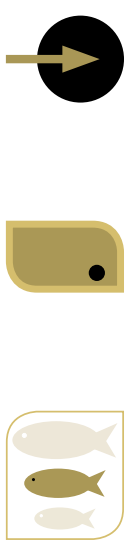

Corpo cinza-escuro, mais claro na região ventral, nadadeiras com pigmentos escuros dispersos, principalmente sobre os raios. Corpo alongado e coberto por duas séries de placas laterais altas, as quais são ausentes na região abdominal e boca terminal. Ossos coracoides expostos, não cobertos por pele, barbilhões relativamente longos e nadadeira caudal bifurcada.

Altura do corpo contida 3,0 a $3,3^{*}$, do pedúnculo caudal 5,6 a $6,5^{*}$ e comprimento da cabeça 3,1 a $3,5^{*}$ vezes no CP. Comprimento do focinho contido 2,1 a $2,2^{*}$, do acúleo dorsal 2,4 a 2,5, diâmetro orbital 5,4 a 6,4* e distância interorbital 1,6 a 1,7* vezes no CC.

Nadadeira dorsal com $\mathrm{I}+7^{*}$ raios, peitoral com I+9 ou 10*, pélvica com 6 * e anal com $8^{*}$ raios. Possui 26 ou $27^{*}$ placas dérmicas na série lateral superior, 23 ou $24^{*}$ na inferior e linha lateral incompleta, com 4 a 6* poros na série lateral superior.

Apresenta distribuição geográfica ampla, sendo encontrada nas bacias hidrográficas dos rios Amazonas, Araguaia, Paraguai, Uruguai, Madeira, São Francisco, Paraná e bacias costeiras do sul e do sudeste do Brasil (BRITTO, 2007). Provavelmente tenha sido introduzida na bacia do rio Iguaçu, por ser utilizada por alguns pescadores como isca viva. Na planície de inundação do alto rio Paraná, apresenta hábito alimentar invertívoro, ou seja, alimenta-se de invertebrados, tanto bentônicos como pelágicos (HAHN; FUGI; ANDRIAN, 2004). É considerada não migradora e sem cuidado parental (SUZUKI; PELICICE; LUIZ; LATINI; AGOSTINHO, 2004) e a reprodução estende-se de setembro a abril, com maior intensidade em janeiro e fevereiro, sendo que os indivíduos iniciam a atividade reprodutiva com $\mathrm{L}_{50}=83,0 \mathrm{~mm}$ (VAZZOLER; SUZUKI; MARQUES; LIZAMA, 1997). 


\section{FAMÍLIA}

\section{Loricariidae}

Espécies da família Loricariidae possuem uma grande variação em relação ao tamanho corporal, desde pequenos cascudinhos a indivíduos de grande porte. Apresentam o corpo coberto por várias séries de placas dérmicas, geralmente se alimentam no fundo e possuem boca em posição ventral. A família Loricariidae é composta de seis subfamílias (REIS; PEREIRA; ARMBRUSTER, 2006), das quais, quatro são encontradas no rio Iguaçu (Neoplecostominae, Hypoptopomatinae, Loricariinae e Hypostominae).

\section{SUBFAMÍLIA}

\section{Neoplecostominae}

Composta por cascudinhos de pequeno porte, de corpo baixo, alongado e pedúnculo caudal arredondado, essa subfamília abrange seis gêneros: Hemipsilichthys, Isbrueckerichthys, Kronichthys, Neoplecostomus, Pareiorhaphis e Pareiorhina (ARMBRUSTER, 2004; PEREIRA, 2005), sendo capturados em corredeiras, entre as pedras ou aderidos à vegetação, entretanto, apenas dois gêneros ocorrem na bacia do baixo rio Iguaçu: Neoplecostomus e Pareiorhaphis.

\section{- Neoplecostomus sp. Cascudinho}

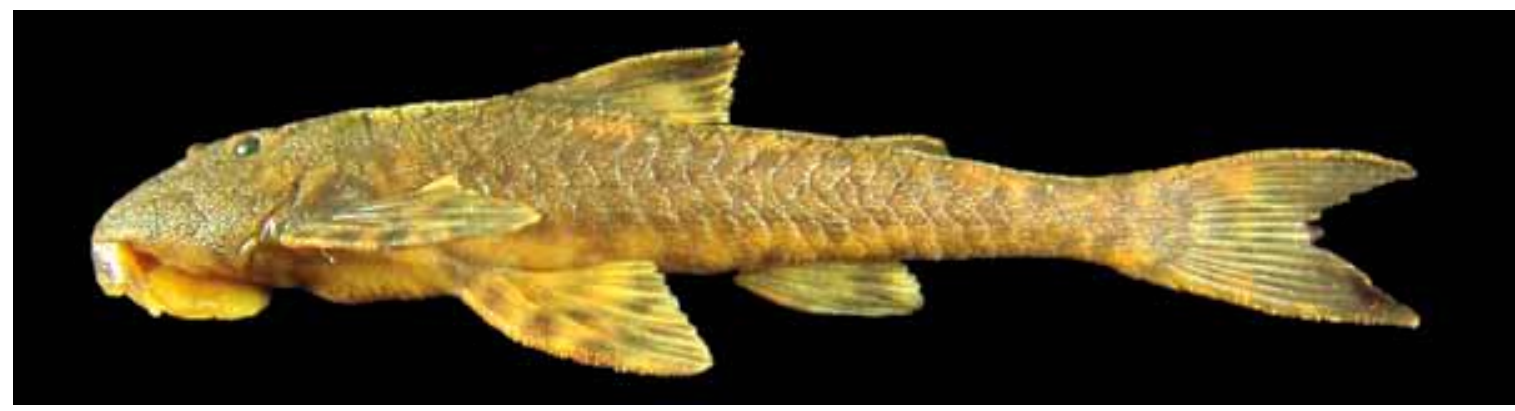

Comprimento padrão 65,5 mm

Corpo e nadadeiras castanhos, com várias manchas cinza-escuras irregulares Corpo coberto por placas dérmicas, cabeça larga, olho pequeno e boca ventral.

Altura do corpo contida 5,4 a 6,7, do pedúnculo caudal 12,7 a 15,5 , comprimento da cabeça 3,0 a 3,4, pré-dorsal 2,3 a 2,5, do $1^{\circ}$ raio da nadadeira dorsal 5,0 a 5,9 e do acúleo da nadadeira peitoral 4,0 a 4,8 vezes no CP. Comprimento do focinho contido 1,6 a 1,8, diâmetro orbital 7,8 a 9,7 e distância interorbital 2,8 a 3,6 vezes no CC.

Nadadeira dorsal com 8 raios, peitoral com I+6, pélvica e anal com 6 raios. Possui 15 a 19 dentes no pré-maxilar, 13 a 17 dentes na hemissérie do dentário, 27 ou 28 placas na série lateral do corpo, 4 placas pré-dorsais e base da nadadeira dorsal com 6 placas.

Esta espécie apresenta distribuição geográfica aparentemente restrita à bacia do rio Iguaçu e está sendo estudada por Edson Henrique Lopes Pereira. 


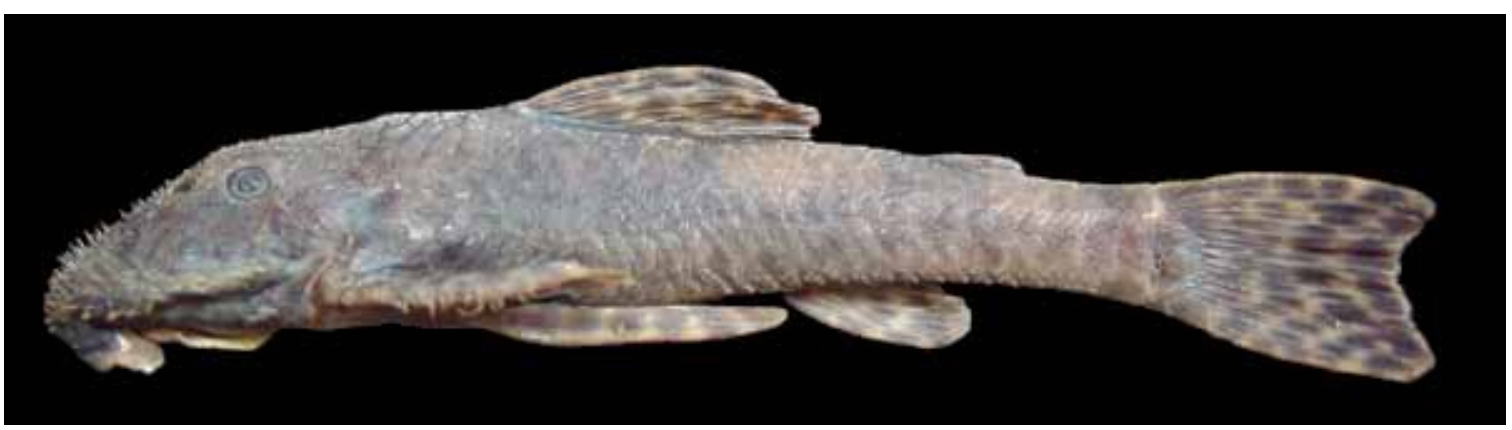

Comprimento padrão 91,1 mm

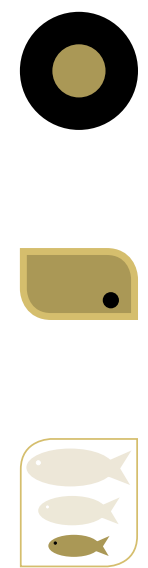

Corpo e nadadeiras castanho-acinzentados, com várias pintas irregulares cinza ou marrom-escuras. Corpo coberto por placas dérmicas, cabeça larga, olho pequeno e boca ventral. Machos adultos com vários odontódeos mais desenvolvidos na borda do focinho.

Altura do corpo contida 5,6, do pedúnculo caudal 10,4, comprimento da cabeça 3,0 , pré-dorsal 2,2 , do $1^{\circ}$ raio da nadadeira dorsal 4,3 e do acúleo da nadadeira peitoral 4,3 vezes no CP. Comprimento do focinho contido 1,6, diâmetro orbital 8,5 e distância interorbital 3,2 vezes no CC.

Nadadeira dorsal com 8 raios, peitoral com I+6, pélvica com 6 e anal com 5 raios. Possui 44 dentes no pré-maxilar, 48 dentes na hemissérie do dentário, 31 placas na série lateral do corpo, 4 placas pré-dorsais e base da nadadeira dorsal com 8 placas.

Esta espécie apresenta distribuição geográfica aparentemente restrita à bacia do rio Iguaçu, onde ocorre esporadicamente, sendo que apenas um exemplar adulto foi capturado na região do baixo Iguaçu. O espécime não apresenta uma placa na região ventral, posterior à abertura branquial, comum da espécie descrita do médio Iguaçu. Portanto, aqui chamamos a espécie de Pareiorhaphis cf. parmula. 


\section{SUBFAMÍLIA}

\section{Hypoptopomatinae}

Essa subfamília é representada por cascudinhos de pequeno porte, onde adultos atingem no máximo 4 centímetros de comprimento e são encontrados aderidos à vegetação ou troncos submersos. Dos 16 gêneros que compõem a subfamília (MARTINS LANGEANI, 2011), apenas Hisonotus é encontrado na bacia do rio Iguaçu.

\section{Chave para espécies de Hisonotus}

1. Faixa clara desde o focinho à região posterior da cabeça presente

1'. Faixa clara desde o focinho à região posterior da cabeça ausente ... Hisonotus sp.

\section{- Hisonotus yasi (Almirón, Azpelicueta \& Casciotta, 2004)} Cascudinho

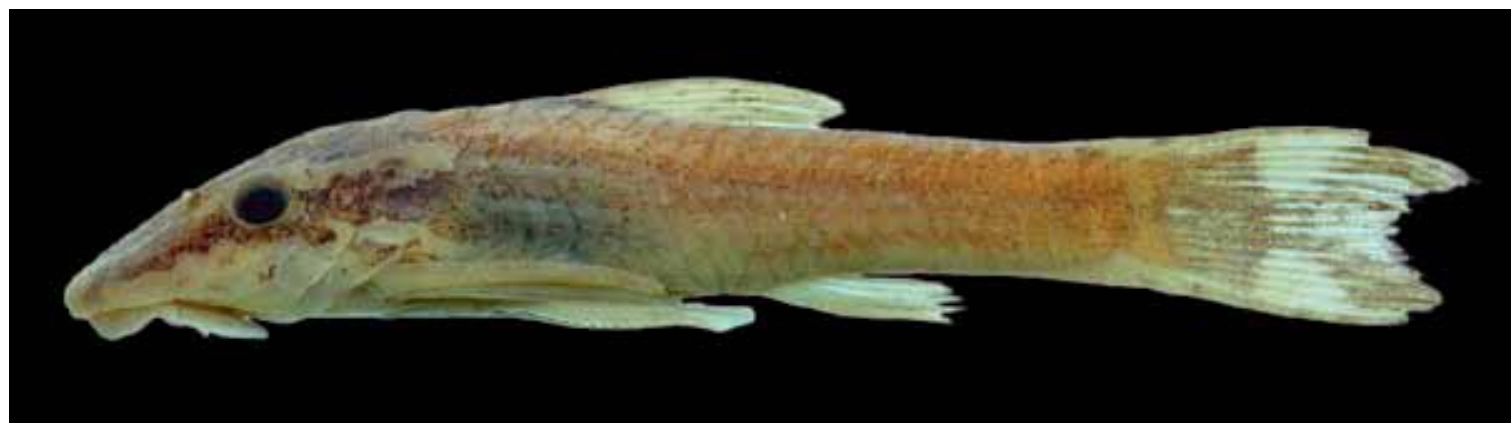

Comprimento padrão $28,8 \mathrm{~mm}$

Corpo castanho no dorso e na lateral, mais claro na região ventral, com uma faixa clara da ponta do focinho ao olho, prolongando-se até a região superior da cabeça. A região dorsal apresenta uma faixa clara estendendo-se da cabeça ao pedúnculo caudal, e duas manchas claras arredondadas estão presentes na nadadeira caudal, uma localizada no lobo superior e a outra no lobo inferior. Corpo baixo, coberto por placas dérmicas e boca ventral. Nadadeira adiposa ausente.

Altura do corpo contida 5,2 a $6,8^{*}$, do pedúnculo caudal 6,8 a $9,3^{*}$, comprimento da cabeça 2,7 a $3,1^{*}$, pré-dorsal 2,1 a $2,4^{*}$, do $1^{\circ}$ raio da nadadeira dorsal 3,8 a $4,8^{*}$ e do acúleo da nadadeira peitoral 3,6 a $4,5^{*}$ vezes no CP. Comprimento do focinho contido 2,6 a 3,3*, diâmetro orbital 6,2 a 7,6* e distância interorbital 2,2 a 2,7* vezes no CC.

Nadadeira dorsal com 8 raios, peitoral com I+6, pélvica e anal com 6 raios. Possui 15 a $20^{*}$ dentes no pré-maxilar, 13 a 20* dentes na hemissérie do dentário, 24 a 27* placas na série lateral do corpo, 3 placas pré-dorsais e base da nadadeira dorsal com 6 placas. 
Identificada como Microlepidogaster sp. no levantamento ictiofaunístico do reservatório de Segredo (GARAVELLO; PAVANELLI; SUZUKI, 1997), essa espécie foi recentemente descrita como Epactionotus yasi. Porém, aqui foi considerada como pertencente ao gênero Hisonotus, por corresponder mais à combinação de caracteres que define este gênero do que a Epactionotus. Essa espécie apresenta distribuição geográfica aparentemente restrita à bacia hidrográfica do rio Iguaçu.

*Almirón, Azpelicueta e Casciotta (2004)

\section{- Hisonotus sp. \\ Cascudinho}

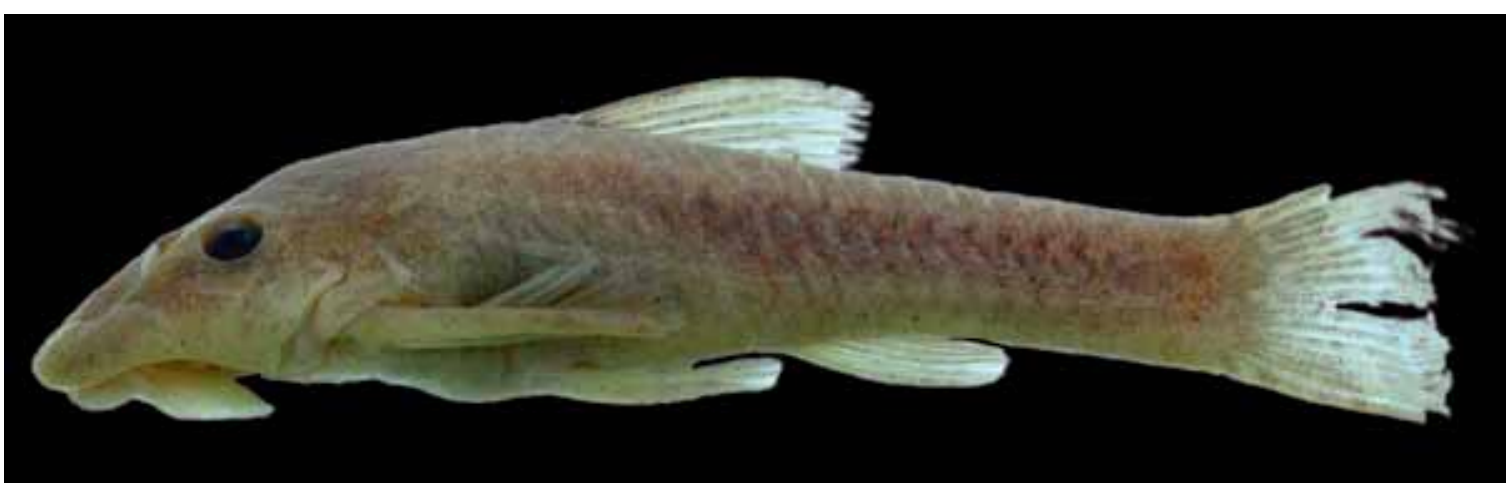

Comprimento padrão 29,7 mm

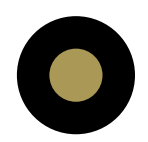

Corpo castanho-claro, bege na região ventral, coberto por placas e boca ventral. Nadadeiras com poucos pigmentos castanhos dispersos, e adiposa ausente.

Altura do corpo contida 4,5 a 5,3, do pedúnculo caudal 7,7 a 8,7, comprimento da cabeça 2,7 a 2,8, pré-dorsal 2,1 , do $1^{\circ}$ raio da nadadeira dorsal 3,8 a 4,0 e do acúleo peitoral 3,6 a 3,9 vezes no CP. Comprimento do focinho contido 1,8 a 1,9, diâmetro orbital 6,6 a 6,9 e distância interorbital 2,5 a 2,6 vezes no CC.

Nadadeira dorsal com 8 raios, peitoral com I+6, pélvica e anal com 6 raios. Possui 10 a 13 dentes no pré-maxilar e 11 na hemissérie do dentário, 24 placas na série lateral do corpo, 3 placas pré-dorsais e base da nadadeira dorsal com 6 placas.

Esta espécie apresenta distribuição geográfica aparentemente restrita à bacia do rio Iguaçu e está em estudo por Roberto Esser dos Reis. 


\section{SUBFAMÍLIA}

\section{Loricariinae}

Com ampla distribuição geográfica na América do Sul, essa subfamília é caracterizada por congregar espécies com o pedúnculo caudal deprimido, nadadeira adiposa ausente e odontódeos bem desenvolvidos na cabeça, corpo e nadadeira peitoral. Os indivíduos são geralmente de pequeno a médio porte. Essa subfamília é composta por 31 gêneros (FERRARIS, 2003b) dos quais somente dois (Loricariichthys e Rineloricaria) são registrados no baixo rio Iguaçu.

\section{Chave para espécies de Loricariichthys}

1. Lado da cabeça e focinho quase retos em vista dorsal L. cf. rostratus

1'. Lado da cabeça e focinho curvados em vista dorsal L. cf. melanocheilus

\section{- Loricariichthys cf. melanocheilus Reis \& Pereira, 2000 Cascudo-chinelo}

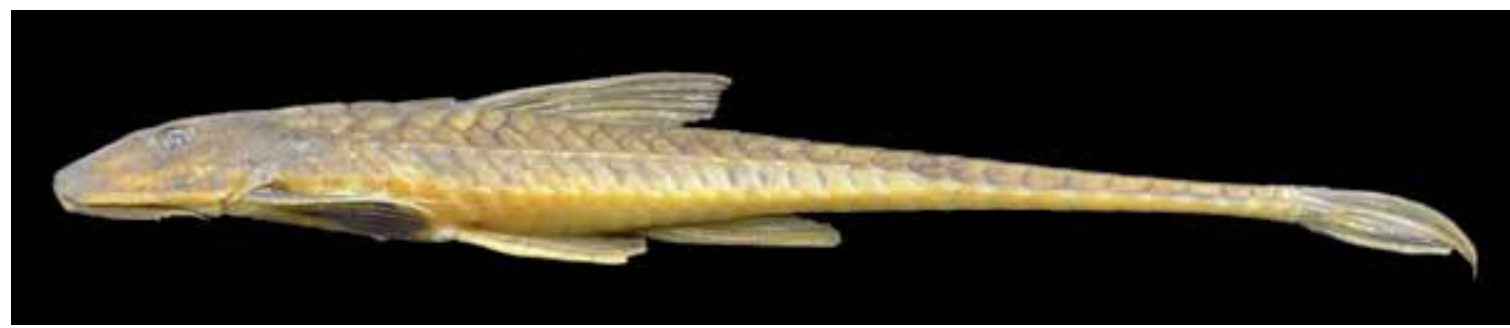

Comprimento padrão 227,2 mm

Corpo e nadadeiras castanhos, com manchas ou pintas pretas, assim como as nadadeiras peitorais e pélvicas, sobretudo em indivíduos maiores. Corpo bege na região ventral, baixo e coberto por placas, boca ventral, cabeça e pedúnculo caudal deprimidos. Machos apresentam prolongamento do lábio inferior em períodos reprodutivos.

Altura do corpo contida 11,4 , do pedúnculo caudal 31,3 a $47,6^{*}$, comprimento da cabeça 4,0 a $4,5^{*}$, pré-dorsal 2,8 a $3,1^{*}$, do $1^{\circ}$ raio da nadadeira dorsal 4,0 a $5,0^{*} \mathrm{e}$ do acúleo peitoral 6,2 a 7,3* vezes no CP. Comprimento do focinho contido 2,0 a 2,2*, diâmetro orbital 5,5 a 7,6* e distância interorbital 4,7 a 5,9* vezes no CC.

Nadadeira dorsal com $8^{*}$ raios, peitoral com $\mathrm{I}+6^{*}$, pélvica e anal com $6^{*}$ raios. Possui 2 a $9^{*}$ dentes no pré-maxilar, 5 a 15* dentes na hemissérie do dentário, 30 a $32^{*}$ placas na série lateral do corpo, 3 placas pré-dorsais e base da nadadeira dorsal com 5 placas.

Esta espécie apresenta distribuição geográfica restrita à bacia do baixo rio Paraná, baixo e médio rio Uruguai (GHAZZI; OYAKAWA, 2007), entretanto, sua captura na bacia do rio Iguaçu é recente e restrita a um único exemplar. 
- Loricariichthys cf. rostratus Reis \& Pereira, 2000

Cascudo-chinelo

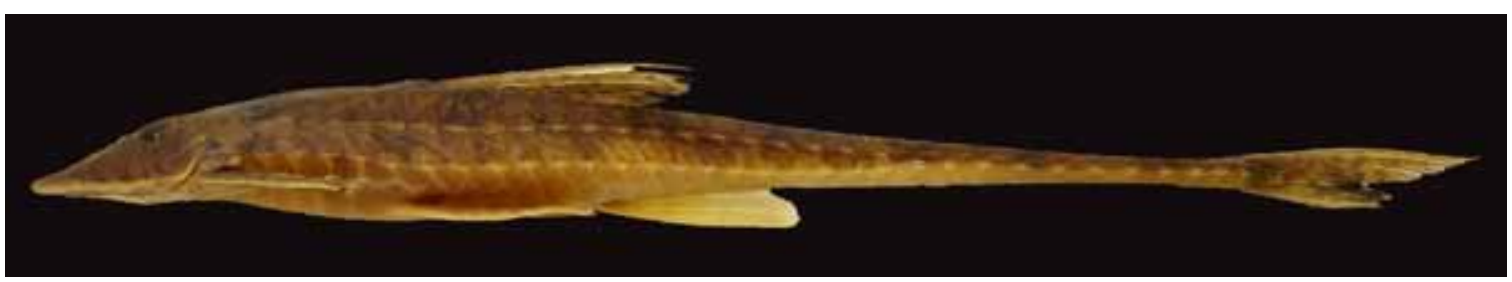

Comprimento padrão 203,6 mm

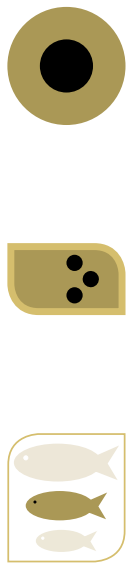

Corpo e nadadeiras castanhos, com manchas marrons e/ou pintas pretas, bege na região ventral. Corpo baixo e coberto por placas, boca ventral, cabeça e pedúnculo caudal deprimidos. Machos apresentam prolongamento do lábio inferior em períodos reprodutivos.

Altura do corpo contida 8,0 a 9,4, do pedúnculo caudal 40,0 a 45,5, comprimento da cabeça 4,3 a 4,8, pré-dorsal 2,8 a 3,0, do $1^{\circ}$ raio da nadadeira dorsal 4,5 a 4,9 e do acúleo peitoral 6,4 a 7,4 vezes no CP. Comprimento do focinho contido 1,8 a 2,1, diâmetro orbital 6,5 a 7,6 e distância interorbital 5,4 a 5,9 vezes no CC.

Nadadeira dorsal com 8 raios, peitoral com $\mathrm{I}+6$, pélvica e anal com 6 raios. Possui 4 a 6 dentes no pré-maxilar e 10 a 15 dentes na hemissérie do dentário, 31 ou 32 placas na série lateral do corpo, 3 placas pré-dorsais e base da nadadeira dorsal com 5 placas.

Esta espécie apresenta distribuição geográfica restrita à bacia do rio Paraná, acima da foz do rio Paraguai (GHAZZI; OYAKAWA, 2007). Sua captura na bacia do rio Iguaçu, no entanto, é restrita à área de influência do reservatório de Salto Caxias. $\mathrm{Na}$ planície de inundação do alto rio Paraná, esta espécie é considerada detritívora (HAHN; ANDRIAN; FUGI; ALMEIDA, 1997; HAHN; FUGI; LOUREIRO-CRIPPA; RUSSO, 2004).

\section{- Rineloricaria maacki Ingenito, Ghazzi, Duboc \& Abilhoa, 2008}

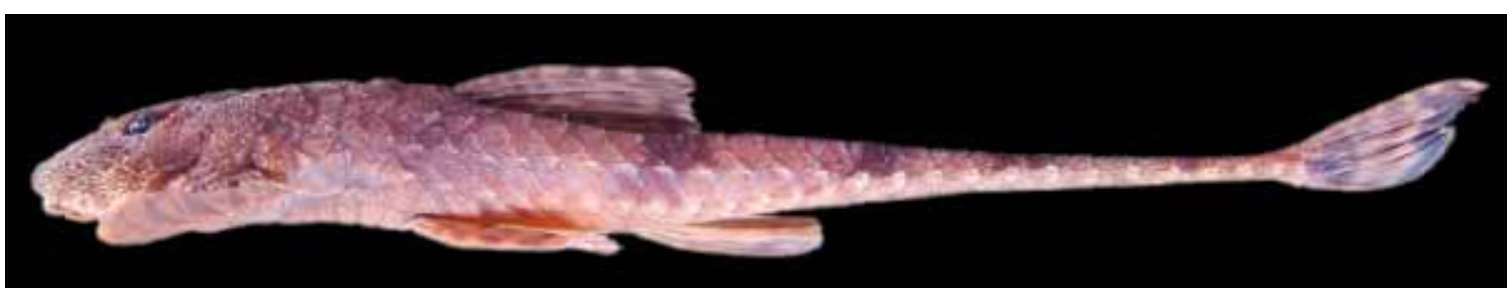

Comprimento padrão 133,8 mm
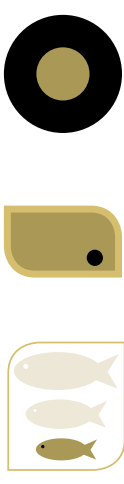

Corpo e nadadeiras castanhos, com cinco faixas transversais pretas no dorso e pintas pretas nas nadadeiras. Corpo baixo, coberto por placas, cabeça e pedúnculo caudal deprimidos e boca ventral. Machos em reprodução apresentam odontódeos bem desenvolvidos nos lados do focinho.

Altura do corpo contida 7,3 a 9,5, do pedúnculo caudal 53,1 a 58,0, comprimento da cabeça 3,8 a $4,3^{*}$, pré-dorsal 2,7 a $3,1^{*}$, do $1^{\circ}$ raio da nadadeira dorsal 4,8 a $5,3^{*}$ e do acúleo peitoral 5,3 a 6,8* vezes no CP. Comprimento do focinho contido 1,9 a 2,1*, diâmetro orbital 4,6 a 5,2* e distância interorbital 3,8 a 4,3* vezes no CC.

Nadadeira dorsal com $8^{*}$ raios, peitoral com I+6*, pélvica e anal com 6* raios. Possui 5 a $8^{*}$ dentes no pré-maxilar e 5 a $8^{*}$ dentes na hemissérie do dentário, 28 a 
$30^{*}$ placas na série lateral do corpo, $3^{*}$ placas pré-dorsais e base da nadadeira dorsal com $5^{\star}$ placas.

Ocorre em rios com fundo lodoso e arenoso, com médio a elevado fluxo de água, habitando locais com pouca ou nenhuma vegetação marginal. Esta espécie apresenta distribuição geográfica restrita à bacia do médio e do baixo rio Iguaçu (INGENITO; GHAZZI; DUBOC; ABILHOA, 2008).

*Ingenito, Ghazzi, Duboc e Abilhoa (2008)

\section{SUBFAMÍLIA}

\section{Hypostominae}

Algumas espécies dessa subfamília são de médio porte e apreciadas em virtude do seu sabor, o que as torna atrativas à pesca por pescadores locais. No entanto, não são utilizadas comercialmente na região por dificuldade no seu processamento, já que apresentam placas dérmicas difíceis de serem removidas. Em geral, os membros dessa subfamília vivem próximo ao fundo ou entre rochas, onde ficam abrigados durante o dia, sendo ativos principalmente à noite. Normalmente apresentam médio porte, região interopercular pouco móvel, mas provida de pequenos odontódeos e pedúnculo caudal cilíndrico (WEBER, 2003), exceto em indivíduos da tribo Ancistrini, que apresentam interopercular bastante móvel e provido de odontódeos bem desenvolvidos.

\section{Chave para espécies de Ancistrus}

1. Largura do dentário contida 6,5 vezes ou mais no comprimento da cabeça

A. abilhoai

1'. Largura do dentário contida menos de 6,4 vezes no comprimento da cabeça

2. Comprimento da cabeça contido 2,4 a 2,6 vezes no comprimento padrão

A. agostinhoi

2'. Comprimento da cabeça contido 2,6 a 2,9 vezes no comprimento padrão

3. Em machos adultos, ampla região de pele na região látero-superior do focinho, ultrapassando a metade da distância focinho-olho; geralmente tentáculos muito desenvolvidos A. mullerae

3'. Em machos adultos, pequena região de pele na região látero-superior do focinho, não atingindo a metade da distância focinho-olho, tentáculos pouco desenvolvidos

Ancistrus sp.
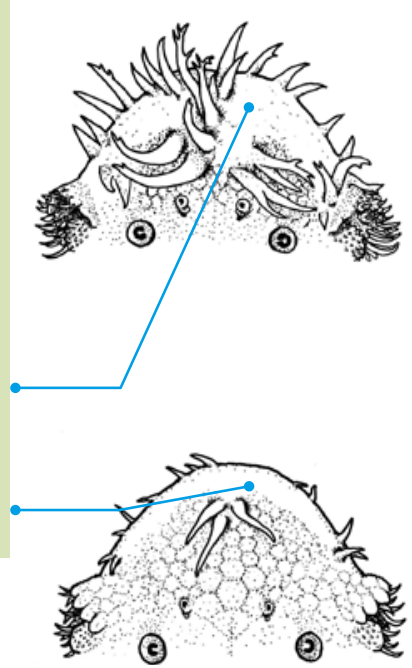


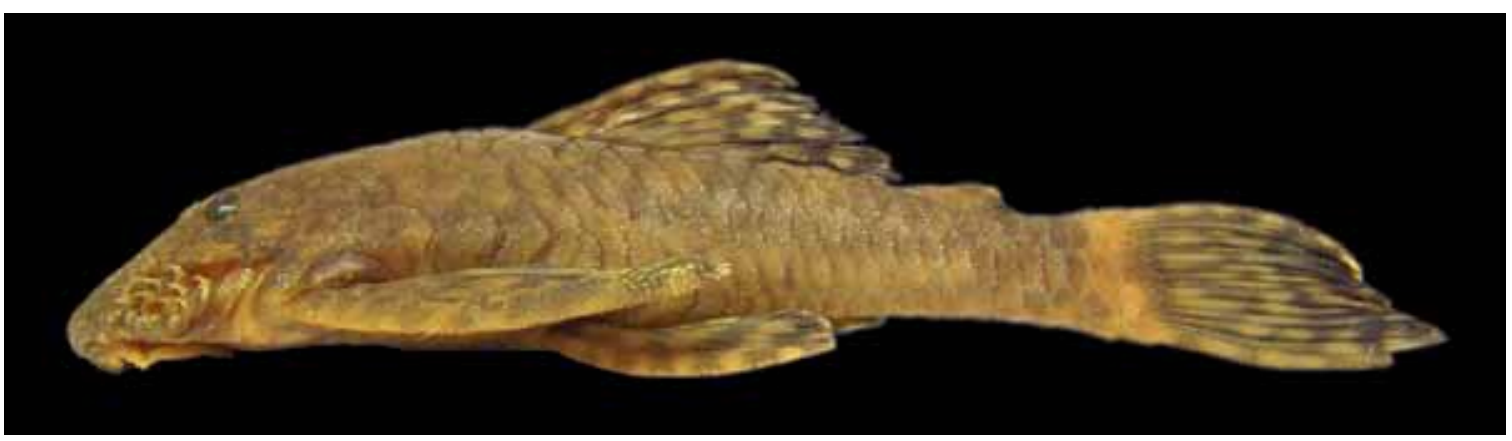

Comprimento padrão 99,3 mm

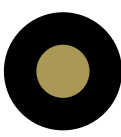

Corpo marrom-oliva, com machas amarelo-claras. Região ventral da cabeça até a nadadeira anal marrom-clara, com manchas amarelo-claras arredondadas ou vermiculadas. Nadadeiras amareladas com manchas cinza-escuras, podendo unir-se e formar três ou quatro faixas ou manchas arredondadas. Nadadeira caudal com manchas amarelo-claras arredondadas, podendo unir-se formando faixas. Corpo alto, coberto por placas dérmicas, odontódeos bem desenvolvidos no interopérculo e boca ventral. Machos adultos com tentáculos na região do focinho.

Altura do corpo contida 4,9 a 5,3*, do pedúnculo caudal 9,1 a $11,1^{*}$, comprimento da cabeça 2,6 a $2,9^{*}$, pré-dorsal 2,1 a $2,2^{*}$, do $1^{\circ}$ raio da dorsal 3,5 a $4,5^{*}$ e do acúleo peitoral 2,4 a $3,4^{*}$ vezes no CP. Comprimento do focinho contido 1,7 a $1,9^{*}$, diâmetro orbital 6,5 a $8,5^{*}$, largura do dentário 6,5 a 7,5* e distância interorbital 2,2 a 2,6* vezes no CC.

Nadadeira dorsal com $8^{*}$ raios, peitoral com $\mathrm{I}+6^{*}$, pélvica com $6^{*}$ e anal com 4 ou $5^{\star}$ raios. Possui 41 a $64^{\star}$ dentes no pré-maxilar e 40 a $68^{*}$ dentes na hemissérie do dentário, 22 a $24^{*}$ placas na série lateral do corpo, $3^{*}$ placas pré-dorsais e 6 ou $7^{*}$ placas na base da nadadeira dorsal.

Essa espécie está distribuída principalmente na região do alto e médio rio Iguaçu, com um único lote capturado no reservatório de Foz do Areia, no baixo Iguaçu (BIFI; PAVANELLI; ZAWADZKI, 2009).

*Bifi, Pavanelli e Zawadzki (2009)

\section{- Ancistrus agostinhoi Bifi, Pavanelli \& Zawadzki, 2009 Cascudo-roseta}

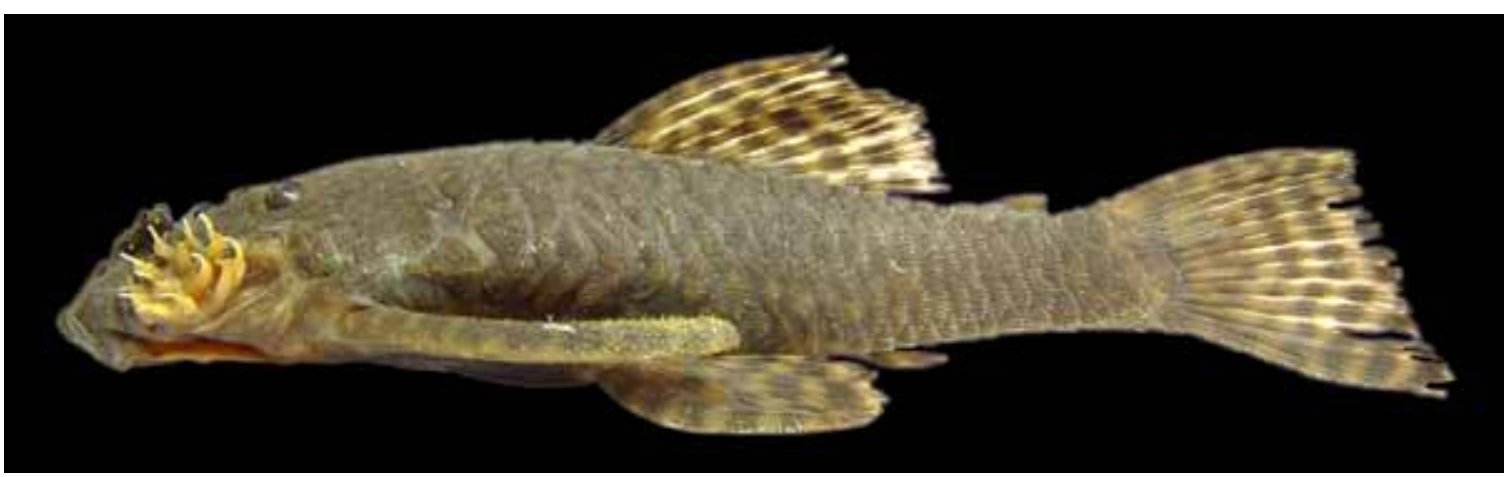

Comprimento padrão 96,1 mm 
Corpo cinza chumbo, com manchas amarelo-claras. Região ventral da cabeça até a nadadeira anal marrom acinzentada, com manchas amarelo-claras arredondadas ou vermiculadas. Nadadeiras amareladas com manchas marrom escuras, podendo unir-se e formar quatro ou cinco faixas. Nadadeira caudal com manchas amarelo-claras arredondadas, podendo unir-se formando faixas. Corpo alto, coberto por placas dérmicas, odontódeos bem desenvolvidos no interopérculo e boca ventral. Machos adultos com tentáculos na região do focinho.

Altura do corpo contida 4,5 a $5,3^{*}$, do pedúnculo caudal 8,3 a $9,4^{*}$, comprimento da cabeça 2,4 a $2,6^{*}$, pré-dorsal 2,0 a $2,2^{*}$, do $1^{\circ}$ raio da dorsal 3,6 a $5,0^{*}$ e do acúleo peitoral 2,7 a $3,7^{*}$ vezes no CP. Comprimento do focinho contido 1,7 a $1,9^{*}$, diâmetro orbital 5,8 a 8,1*, largura do dentário 5,2 a 6,3* e distância interorbital 2,3 a 3,1* vezes no CC.

Nadadeira dorsal com 8 ou 9* raios, peitoral com $\mathrm{I}+6^{*}$, pélvica com $6^{*}$ e anal com 4 ou $5^{*}$ raios. Possui 36 a $74^{*}$ dentes no pré-maxilar e 38 a $78^{*}$ dentes na hemissérie do dentário, 23 ou $24^{*}$ placas na série lateral do corpo, $3^{*}$ placas pré-dorsais e 6 ou 7 * placas na base da nadadeira dorsal.

A distribuição geográfica dessa espécie é restrita à sub-bacia do rio Jordão (BIFI; PAVANELLI; ZAWADZKI, 2009).

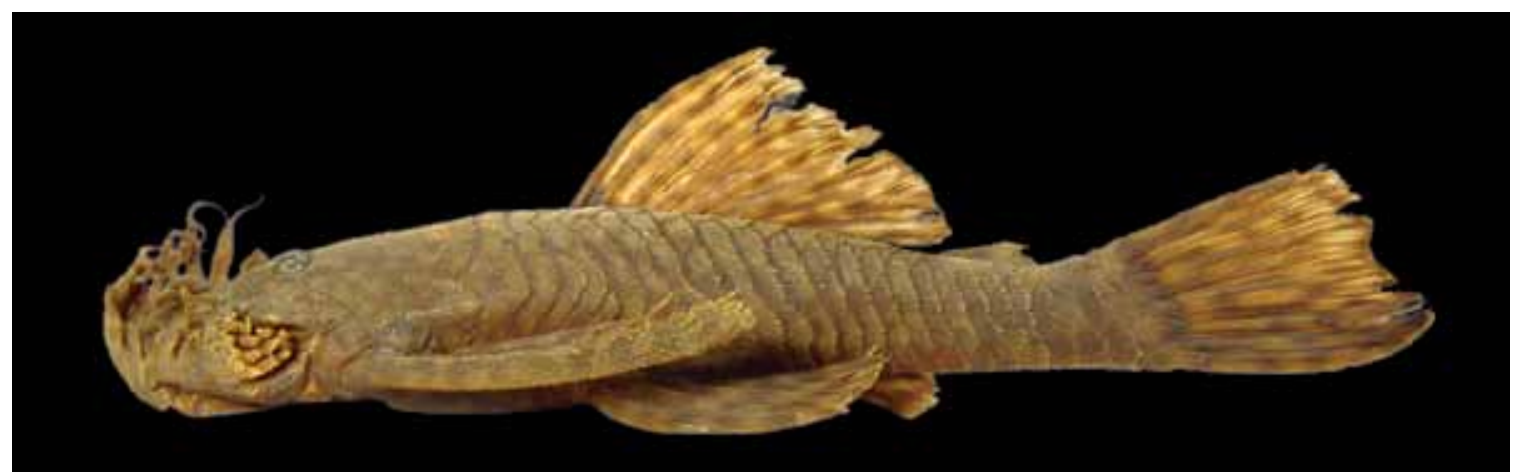

Comprimento padrão 109,1 mm

Corpo marrom-amarelado a escuro, com manchas amarelo-claras. Região ventral da cabeça até a nadadeira anal marrom amarelada, com manchas amarelo-claras arredondadas ou vermiculadas, que podem estar ausentes, principalmente em indivíduos menores. Nadadeiras marrom amareladas, com manchas cinza-escuras, podendo unir-se e formar três ou quatro faixas ou manchas arredondadas. Nadadeira caudal com faixas ou manchas amarelo-claras arredondadas, podendo unir-se formando faixas. Corpo baixo, coberto por placas dérmicas, odontódeos bem desenvolvidos no interopérculo e boca ventral. Machos adultos com tentáculos na região do focinho.

Altura do corpo contida 5,3 a $6,5^{*}$, do pedúnculo caudal 8,7 a $11,4^{*}$, comprimento da cabeça 2,6 a $2,9^{*}$, pré-dorsal 2,1 a $2,3^{*}$, do $1^{\circ}$ raio da dorsal 3,3 a $4,9^{*}$ e do acúleo peitoral 2,4 a $3,8^{*}$ vezes no CP. Comprimento do focinho contido 1,7 a $2,0^{*}$, diâmetro orbital 5,4 a 8,4*, largura do dentário 4,8 a 6,1* e distância interorbital 2,3 a 3,0* vezes no CC. 
Nadadeira dorsal com $8^{*}$ raios, peitoral com $\mathrm{I}+6^{*}$, pélvica com $6^{*}$ e anal com 4 ou $5^{*}$ raios. Possui 45 a $88^{*}$ dentes no pré-maxilar e 51 a $97^{*}$ dentes na hemissérie do dentário; 22 a $24^{*}$ placas na série lateral, $3^{*}$ placas pré-dorsais e 6 ou $7^{*}$ placas na base da nadadeira dorsal.

Identificada como Ancistrus sp. nos estudos realizados no reservatório de Salto Caxias, essa espécie alimenta-se basicamente de algas e detritos de sedimentos, sendo considerada detritívora (DELARIVA, 2002). O período reprodutivo ocorre de setembro a dezembro (UNIVERSIDADE ESTADUAL DE MARINGÁ, 2002). Esta espécie distribui-se no baixo rio Iguaçu, principalmente na região do reservatório de Salto Caxias (BIFI; PAVANELLI; ZAWADZKI, 2009).

*Bifi, Pavanelli e Zawadzki (2009)

- Ancistrus sp.

Cascudo-roseta

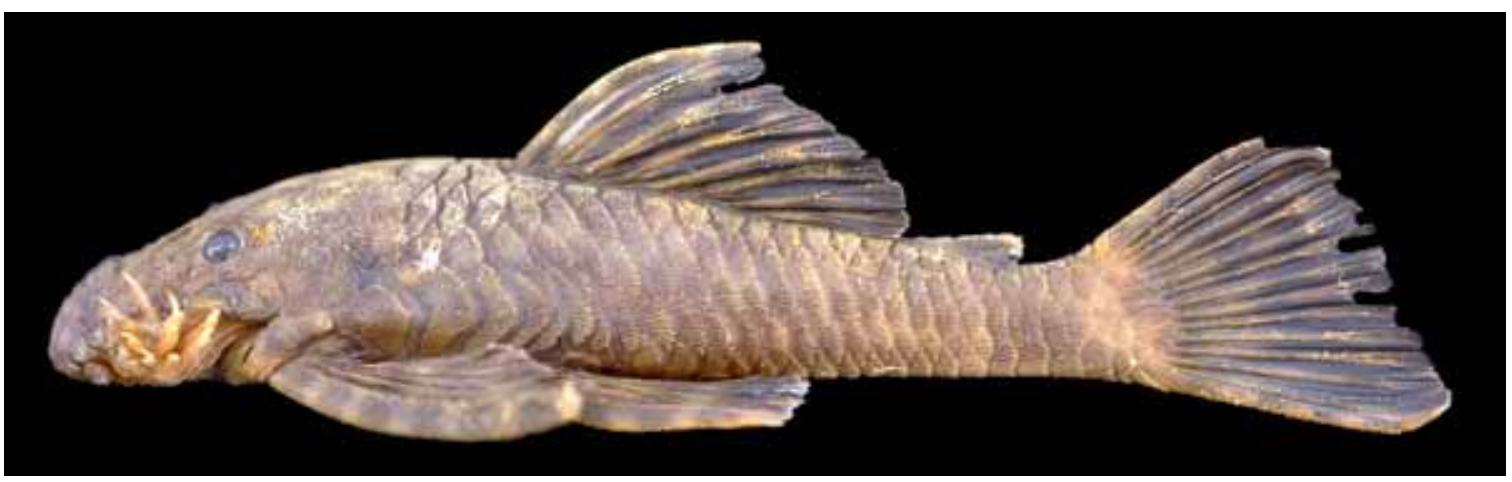

Comprimento padrão $98,3 \mathrm{~mm}$

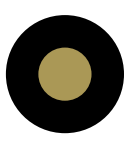

Corpo cinza-escuro, com manchas amarelo-claras. Região ventral da cabeça até a nadadeira anal marrom acinzentada, com manchas amarelo-claras arredondadas ou vermiculadas. Nadadeiras cinza amareladas com manchas cinza-escuras, podendo unir-se e formar faixas. Nadadeira caudal com manchas amarelo-claras arredondadas, podendo unir-se formando faixas. Corpo alto, coberto por placas dérmicas, com odontódeos bem desenvolvidos no interopérculo e boca ventral. Machos adultos com tentáculos na região do focinho.

Altura do corpo contida 4,9 a 5,6, do pedúnculo caudal 8,5 a 9,7, comprimento da cabeça 2,6 a 2,8, pré-dorsal 2,0 a 2,3, do $1^{\circ}$ raio da dorsal 3,5 a 4,2 e do acúleo peitoral 2,6 a 3,5 vezes no CP. Comprimento do focinho contido 1,7 a 1,9, diâmetro orbital 6,3 a 8,2, largura do dentário 5,1 a 6,2 e distância interorbital 2,2 a 3,0 vezes no CC.

Nadadeira dorsal com 8 raios, peitoral com I+6, pélvica com 6 e anal com 5 raios. Possui 44 a 83 dentes no pré-maxilar e 46 a 86 dentes na hemissérie do dentário, 23 ou 24 placas na série lateral do corpo, 3 placas pré-dorsais e 7 placas na base da nadadeira dorsal.

No reservatório de Segredo, essa espécie alimenta-se basicamente de algas e detritos de sedimentos, sendo considerada como detritívora (HAHN; FUGI; ALMEIDA; RUSSO; LOUREIRO, 1997). O período reprodutivo ocorre de setembro a fevereiro e a atividade reprodutiva inicia-se com $C P=65,0 \mathrm{~mm}$ nos machos e $\mathrm{CP}=54,0 \mathrm{~mm}$ nas fêmeas (SUZUKI; AGOSTINHO, 1997). Esta espécie ocorre no baixo rio Iguaçu, principalmente na região do reservatório de Segredo. Aparentemente é nova para a ciência e está em estudo por Alessandro G. Bifi, Carla S. Pavanelli e Cláudio H. Zawadzki. 


\section{Chave para espécies de Hypostomus}

1. Manchas e/ou pintas claras distribuídas pelo corpo e nadadeiras

1'. Manchas e/ou pintas escuras distribuídas pelo corpo e nadadeiras .................. 3

2. Acúleo da nadadeira peitoral igual ou menor do que o primeiro raio da pélvica, seu comprimento contido 3,4 ou mais vezes no comprimento padrão; focinho relativamente longo, seu comprimento contido 1,5 vezes ou menos no comprimento da cabeça H. albopunctatus

2'. Acúleo da nadadeira peitoral maior do que o primeiro raio da pélvica, seu comprimento contido 3,4 vezes ou menos no comprimento padrão; focinho relativamente curto, seu comprimento contido 1,5 vezes ou mais no comprimento da cabeça H. myersi

3. Nadadeira dorsal relativamente longa, alcançando a adiposa, quando adpressa, comprimento do seu $1^{\circ}$ raio contido 3 vezes ou menos no comprimento padrão H. commersoni

3'. Nadadeira dorsal relativamente curta, não alcançando a adiposa, quando adpressa, comprimento do seu $1^{\circ}$ raio contido 3,1 vezes ou mais no comprimento padrão

- Hypostomus albopunctatus (Regan, 1908)

Cascudo

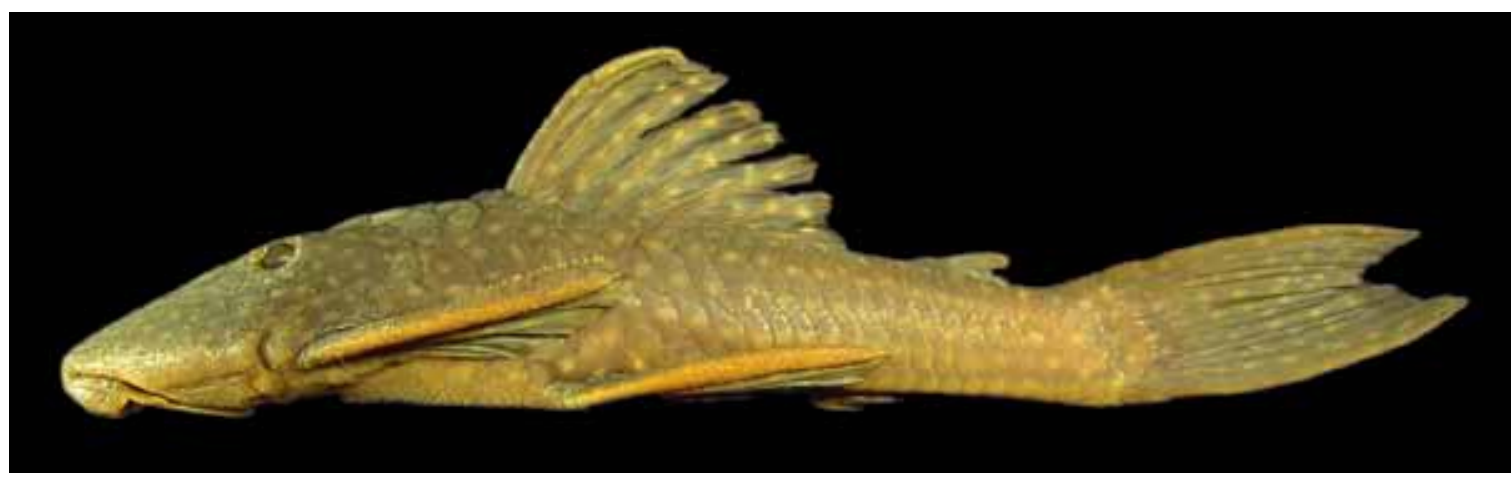

Comprimento padrão 205,6 mm

Corpo e nadadeiras castanho escuros, com pintas claras. Corpo baixo, coberto por placas dérmicas desprovidas de quilhas, cabeça deprimida e boca ventral.

Altura do corpo contida 4,6 a 7,4, do pedúnculo caudal 8,5 a 9,3, comprimento da cabeça 2,8 a 3,0, pré-dorsal 2,2 a 2,4, do $1^{\circ}$ raio da dorsal 3,6 a 4,5 e do acúleo peitoral 3,4 a 3,9 vezes no CP. Comprimento do focinho contido 1,4 a 1,5, diâmetro orbital 7,1 a 9,1 e distância interorbital 3,0 a 3,4 vezes no CC.

Nadadeira dorsal com 8 raios, peitoral com I+6, pélvica com 6 e anal com 5 raios. Possui 29 a 51 dentes no pré-maxilar e 28 a 44 dentes na hemissérie do dentário; 24 a 26 placas na série lateral do corpo, 3 ou 4 placas pré-dorsais e base da nadadeira dorsal com 8 placas.

Essa espécie foi considerada detritívora no reservatório de Segredo, consumindo preferencialmente detrito/sedimento, porém, pode alternativamente utilizar 
outros itens alimentares como algas, insetos, microcrustáceos e outros invertebrados (HAHN; FUGI; ALMEIDA; RUSSO; LOUREIRO, 1997). O período reprodutivo estende-se de dezembro a fevereiro (UNIVERSIDADE ESTADUAL DE MARINGÁ, 2002). Essa espécie apresenta distribuição geográfica por toda a bacia do alto rio Paraná (WEBER, 2003) e bacia do rio Iguaçu (GARAVELLO; PAVANELLI; SUZUKI, 1997; BAUMGARTNER; BAUMGARTNER; PAVANELLI; SILVA; FRANA; OLIVEIRA; MICHELON, 2006).

\section{- Hypostomus commersoni Valenciennes, 1836 Cascudo-avião}

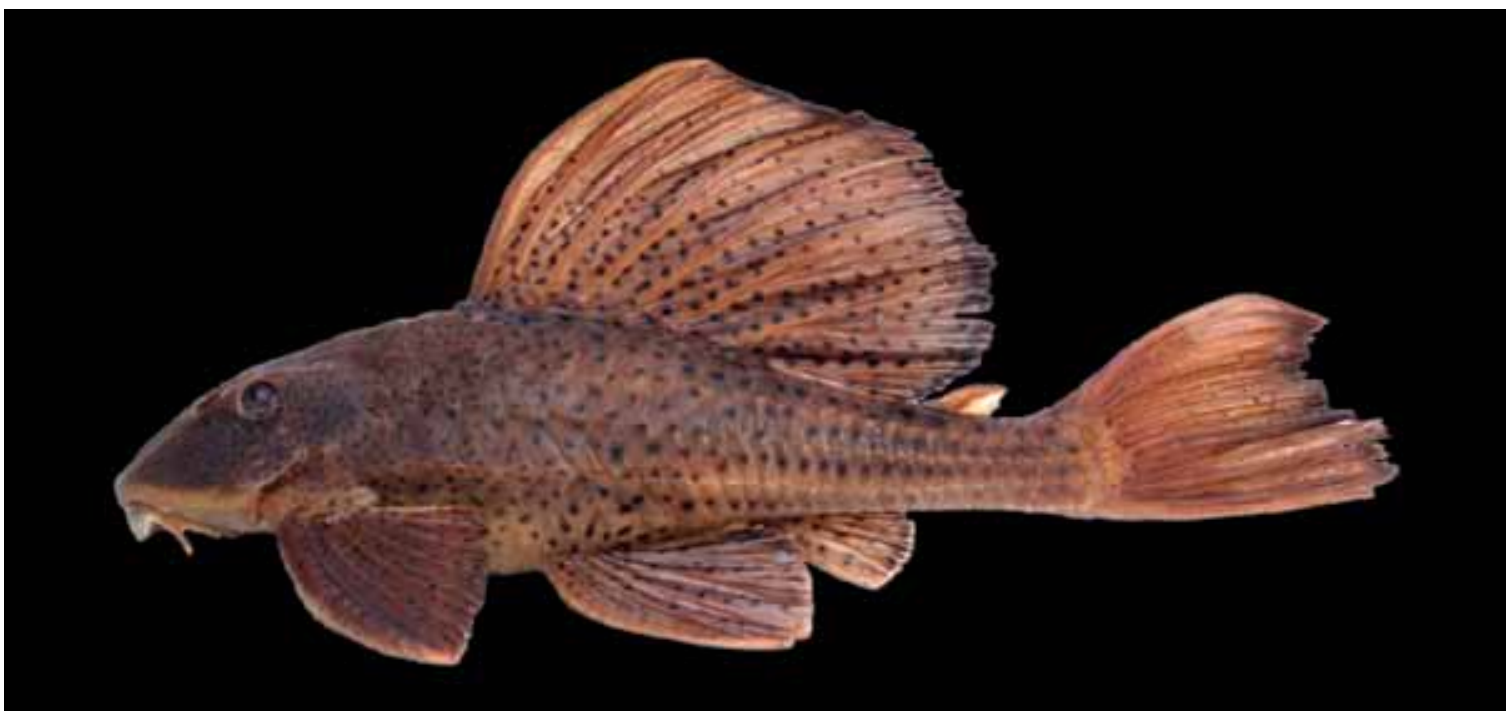

Comprimento padrão 230,0 mm

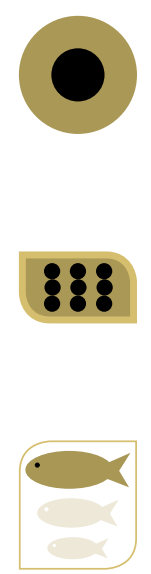

Corpo e nadadeiras castanhos, com várias pintas pretas. Nadadeiras bem desenvolvidas, destacando-se a dorsal, que é relativamente maior quando comparada à de suas congêneres. Corpo alto, coberto por placas dérmicas quilhadas, cabeça alta e boca ventral.

Altura do corpo contida 4,1 a 5,8, do pedúnculo caudal 9,2 a 11,5, comprimento da cabeça 3,0 a 3,3, pré-dorsal 2,4 a 2,6, do $1^{\circ}$ raio da dorsal 2,1 a 3,0 e do acúleo peitoral 2,8 a 3,6 vezes no CP. Comprimento do focinho contido 1,6 a 1,8, diâmetro orbital 5,5 a 9,1 e distância interorbital 2,3 a 2,6 vezes no CC.

Nadadeira dorsal com 8 raios, peitoral com I+6, pélvica com 6 e anal com 5 raios. Possui 23 a 41 dentes no pré-maxilar e 24 a 54 dentes na hemissérie do dentário; 28 a 30 placas na série lateral do corpo, 3 placas pré-dorsais e 9 ou 10 placas na base da nadadeira dorsal.

Seu período reprodutivo estende-se de dezembro a fevereiro (UNIVERSIDADE ESTADUAL DE MARINGÁ, 2002). Essa espécie está distribuída nas bacias hidrográficas do médio e baixo rio Paraná, do rio Uruguai, da laguna dos Patos (WEBER, 2003) e do rio Iguaçu (GARAVELLO; PAVANELLI; SUZUKI, 1997; BAUMGARTNER; BAUMGARTNER; PAVANELLI; SILVA; FRANA; OLIVEIRA; MICHELON, 2006). 
- Hypostomus derbyi (Haseman, 1911)

Cascudo-amarelo

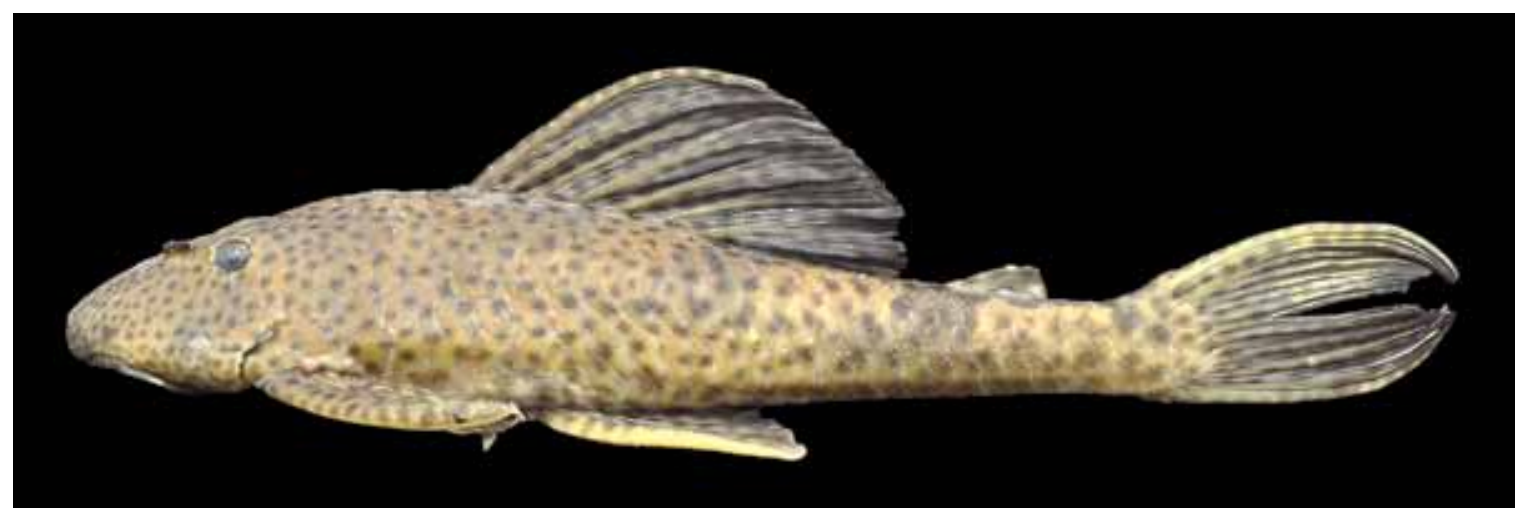

Comprimento padrão 205,0 mm

Corpo e nadadeiras castanhos, com muitas pintas pretas. Corpo alto, coberto por placas dérmicas com quilhas pouco pronunciadas e boca ventral.

Altura do corpo contida 4,8 a $6,6^{*}$, do pedúnculo caudal 9,4 a 11,5 , comprimento da cabeça 3,0 a 3,6*, pré-dorsal 2,3 a 2,6* do $1^{\circ}$ raio da dorsal 3,1 a $3,7^{*}$ e do acúleo peitoral 3,5 a $3,9^{*}$ vezes no CP. Comprimento do focinho contido 1,6 a 2,0*, diâmetro orbital 6,8 a $10,7^{*}$ e distância interorbital 2,4 a 3,0* vezes no CC.

Nadadeira dorsal com 8 raios, peitoral com I+6, pélvica com 6 e anal com 5 raios. Possui 17 a 28 dentes no pré-maxilar e 16 a 29 dentes na hemissérie do dentário; 27 ou 28 placas na série lateral do corpo, 3 placas pré-dorsais e 7 ou 8 placas na base da nadadeira dorsal.

Essa espécie alimenta-se de detritos e sedimentos (HAHN; FUGI; ALMEIDA; RUSSO; LOUREIRO, 1997), seu período reprodutivo estende-se de outubro a janeiro (UNIVERSIDADE ESTADUAL DE MARINGÁ, 2002), sendo que os indivíduos iniciam a atividade reprodutiva com $C P=125,0 \mathrm{~mm}$ nos machos e $C P=150,0 \mathrm{~mm}$ nas fêmeas (SUZUKI; AGOSTINHO, 1997). Essa espécie apresenta distribuição geográfica restrita à bacia do Iguaçu e arroio Urugua-í, bacia do rio Paraná na Argentina (CARVALHO; BOCKMANN, 2007).

*Gómez, López e Toresani (1990) 
- Hypostomus myersi (Gosline, 1947)

Cascudo

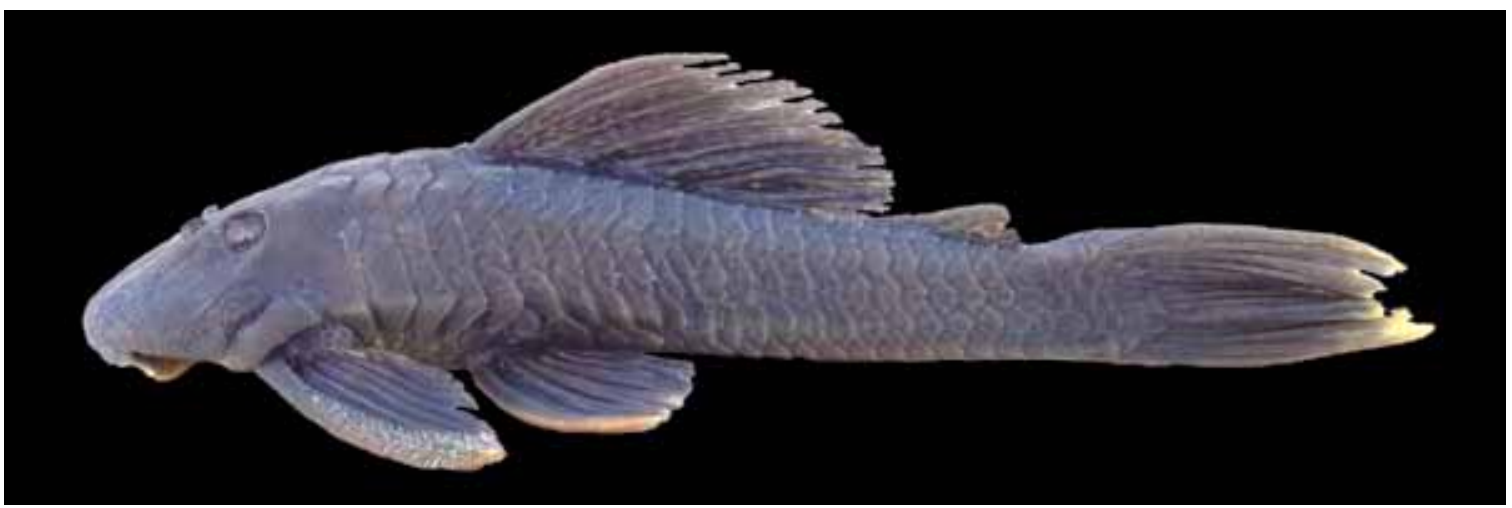

Comprimento padrão 230,0 mm

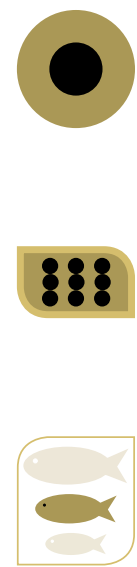

Corpo e nadadeiras marrom-acinzentados, com várias pintas amarelo-claras, às vezes unidas, formando vermiculações, região ventral do corpo clara. Corpo alto, coberto por placas dérmicas desprovidas de quilhas e boca ventral.

Altura do corpo contida 4,6 a $5,5^{*}$, do pedúnculo caudal 9,1 a 9,8, comprimento da cabeça 2,9 a 3,2*, pré-dorsal 2,2 a $2,5^{*}$, do $1^{\circ}$ raio da dorsal 3,3 a 4,0* e do acúleo peitoral 2,7 a $3,4^{*}$ vezes no CP. Comprimento do focinho contido 1,5 a $1,6^{*}$, diâmetro orbital 6,2 a 9,2* e distância interorbital 2,6 a 2,8* vezes no CC.

Nadadeira dorsal com 8 raios, peitoral com I+6, pélvica com 6 e anal com 5 raios. Possui 47 a 56 dentes no pré-maxilar e 46 a 62 dentes na hemissérie do dentário; 24 a 26 placas na série lateral do corpo, 3 ou 4 placas pré-dorsais e 8 ou 9 placas na base da nadadeira dorsal.

Essa espécie habita regiões de fundo e de margem, alimentando-se basicamente de detritos e sedimentos, não possui um padrão nítido de ritmo alimentar, mas pode se intensificar durante o outono. A reprodução se estende de novembro a fevereiro, com preferência para ambientes lóticos, sendo que a atividade reprodutiva inicia com tamanhos diferentes de acordo com os ambientes considerados. No reservatório de Salto Caxias a atividade inicia com $L_{50}=77,0 \mathrm{~mm}$ nas fêmeas (UNIVERSIDADE ESTADUAL DE MARINGÁ, 2002), enquanto que no reservatório de Segredo esta atividade inicia com $C P=85,0 \mathrm{~mm}$ nos machos e $\mathrm{CP}=87,0 \mathrm{~mm}$ nas fêmeas (SUZUKI; AGOSTI$\mathrm{NHO}, 1997)$. A distribuição geográfica dessa espécie é restrita à bacia do rio Iguaçu e Urugua-í, na Argentina (CARVALHO; BOCKMANN, 2007).

*Gómez, López e Toresani (1990) 


\section{FAMÍLIA

A família Heptapteridae, proposta na década de 90 e amplamente aceita, ainda apresenta problemas de ordem taxonômica (BOCKMANN; GUAZZELLI, 2003), tendo em vista que seus exemplares possuem grandes semelhanças com os da família $\mathrm{Pi}$ melodidae, das quais podem ser diferenciados por apresentar o canal látero-sensorial cefálico não ramificado. Em algumas regiões do país os exemplares de menor porte são utilizados por aquariofilistas, enquanto os de maior porte são muito apreciados na pesca comercial (GRAÇA; PAVANELLI, 2007). No rio Iguaçu não é registrada atividade comercial referente a essa família, mas seus exemplares são muito apreciados por pescadores locais e ribeirinhos, o que denota um enorme potencial para essa atividade. Em geral, são de pequeno a grande porte, apresentam três pares de barbilhões (um maxilar e dois mentonianos), nadadeira adiposa bem desenvolvida, corpo desprovido de placas ou escamas, membrana branquial não unida ao istmo e abertura branquial ampla (BOCKMANN; GUAZZELLI, 2003). No baixo rio Iguaçu ocorrem os gêneros Heptapterus, "Pariolius" e Rhamdia.

- Heptapterus sp.

Bagre-da-pedra

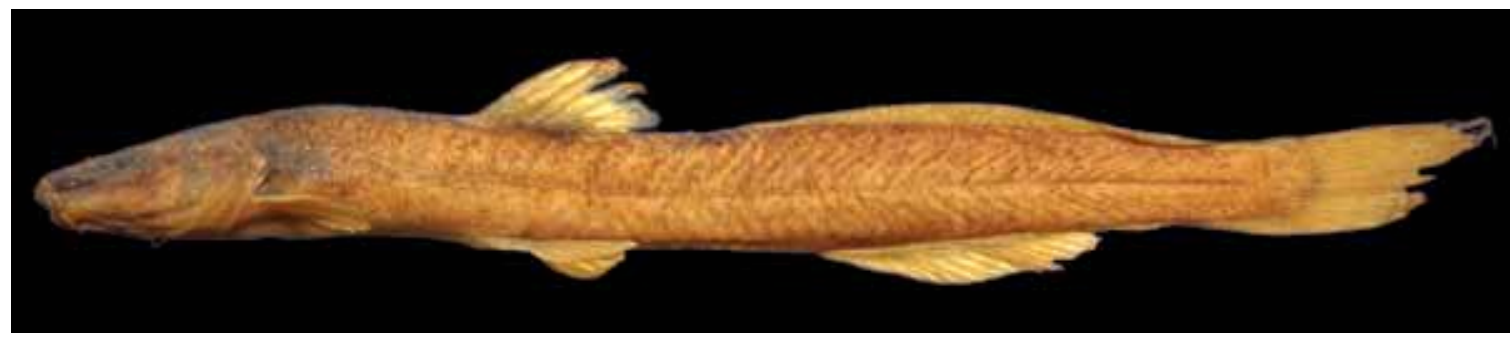

Comprimento padrão $166,1 \mathrm{~mm}$

Corpo e nadadeiras marrom-acinzentados, mais claro no ventre. Corpo alongado, arredondado próximo à cabeça, comprimido na região da base da nadadeira adiposa, a qual é bem longa, cabeça deprimida e boca subterminal.

Altura do corpo contida 7,2 a 9,7, do pedúnculo caudal 12,0 a 14,5 , comprimento da cabeça 4,8 a 5,5, da base da nadadeira anal 4,5 a 5,5 e da base da nadadeira adiposa 2,6 a 2,8 vezes no CP. Comprimento do focinho contido 2,3 a 2,6, diâmetro orbital 6,8 a 9,0 e distância interorbital 4,3 a 5,5 vezes no CC.

Nadadeira dorsal com 7 raios, peitoral com 8 ou 9, pélvica com 6 e anal com 16 a 18 raios.

A distribuição geográfica desta espécie provavelmente é restrita à bacia hidrográfica do rio Iguaçu. Heptapterus stewarti Haseman, 1911, descrita do alto rio Iguaçu, diferencia-se dessa espécie por apresentar uma nadadeira anal longa, com a base contida menos que 3,4 vezes no CP e com mais de 25 raios. Entretanto, este nome foi utilizado por Garavello, Pavanelli e Suzuki (1997) para designar esta espécie. Em estudo por Flávio A. Bockmann.

\section{Chave para espécies de "Pariolius"}

1. Nadadeira dorsal com oito raios " $P$ ". hollandi

1'. Nadadeira dorsal com sete raios

"Pariolius" sp. 
- "Pariolius" hollandi (Haseman, 1911)

Bagre-pedra, guasco

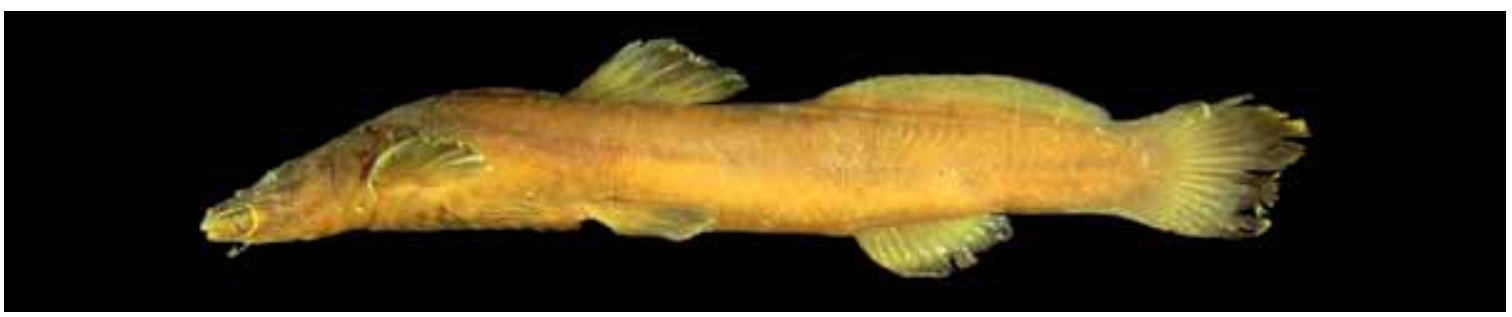

Comprimento padrão 111,1 mm

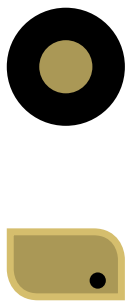

Corpo marrom a cinza-escuro, claro na região ventral e nadadeiras cinza-claras. Corpo alongado, deprimido na região da cabeça e comprimido no pedúnculo caudal, nadadeira adiposa longa e boca terminal.

Altura do corpo contida 6,7 a 9,9, do pedúnculo caudal 12,1 a 15,8, comprimento da cabeça 4,1 a 5,4, da base da nadadeira anal 6,7 a 8,7 e da nadadeira adiposa 2,8 a 3,6 vezes no CP. Comprimento do focinho contido 2,3 a 2,6, diâmetro orbital 5,2 a 8,1 e distância interorbital 6,1 a 8,2 vezes no CC.

Nadadeira dorsal com 8 raios, peitoral com 9 ou 10, pélvica com 6 e anal com 10 ou 11 raios.

A distribuição geográfica desta espécie provavelmente é restrita à bacia hidrográfica do rio Iguaçu (BOCKMANN; GUAZZELLI, 2003). Pertence a um gênero que está sendo descrito por Flávio A. Bockmann. Durante o processo de descrição, ele sugeriu a utilização do nome "Pariolius" entre aspas, indicando que o nome do gênero está sendo utilizado apenas provisoriamente (Flávio A. Bockmann, comunicação pessoal).

- "Pariolius" sp.

Bagre-pedra, guasco

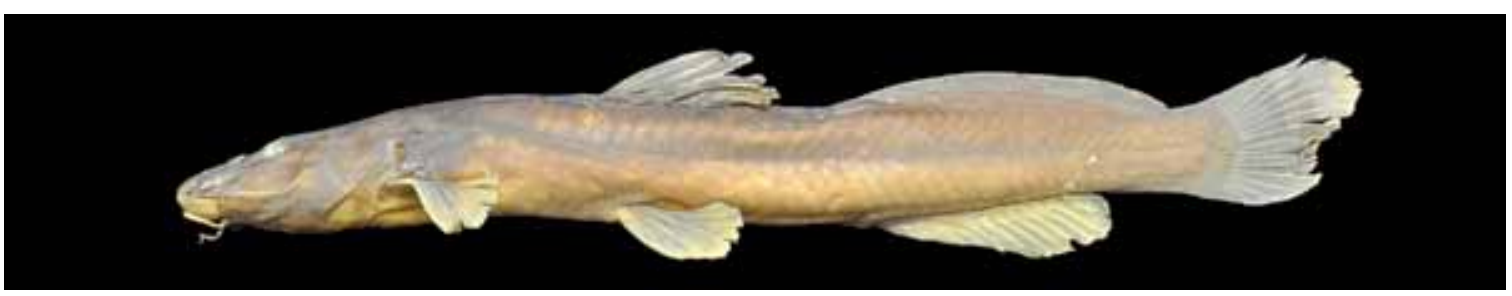

Comprimento padrão $178,0 \mathrm{~mm}$

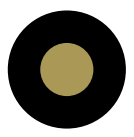

Corpo marrom a cinza-escuro, claro na região ventral e nadadeiras cinza-claras. Corpo alongado, deprimido na região da cabeça e comprimido no pedúnculo caudal, nadadeira adiposa longa e boca terminal.

Altura do corpo contida 7,0 a 8,8, do pedúnculo caudal 10,1 a 15,9, comprimento da cabeça 3,9 a 5,3, da base da nadadeira anal 5,9 a 8,1 e da base da nadadeira adiposa 3,0 a 3,7 vezes no CP. Comprimento do focinho contido 2,4 a 2,6, diâmetro orbital 6,1 a 7,9 e distância interorbital 5,9 a 8,1 vezes no CC.

Nadadeira dorsal com 7 raios, peitoral com 9 ou 10, pélvica com 6 e anal com 10 a 13 raios.

A distribuição geográfica desta espécie provavelmente é restrita à bacia hidrográfica do rio Iguaçu. Pertence a um gênero que está sendo descrito por Flávio A. Bockmann. Durante o processo de descrição, ele sugeriu a utilização do nome "Pariolius" entre aspas, indicando que o nome do gênero está sendo utilizado apenas provisoriamente (Flávio A. Bockmann, comunicação pessoal). 


\section{Chave para espécies de Rhamdia}

1. Perfil convexo entre o processo supraoccipital e a nadadeira dorsal .... Rhamdia sp.

1'. Perfil reto entre o processo supraoccipital e a nadadeira dorsal 2

2. Nadadeira dorsal alcança a adiposa, quando adpressa R. voulezi

2'. Nadadeira dorsal não alcança a adiposa, quando adpressa

R. branneri

- Rhamdia branneri Haseman, 1911

Bagre, jundiá

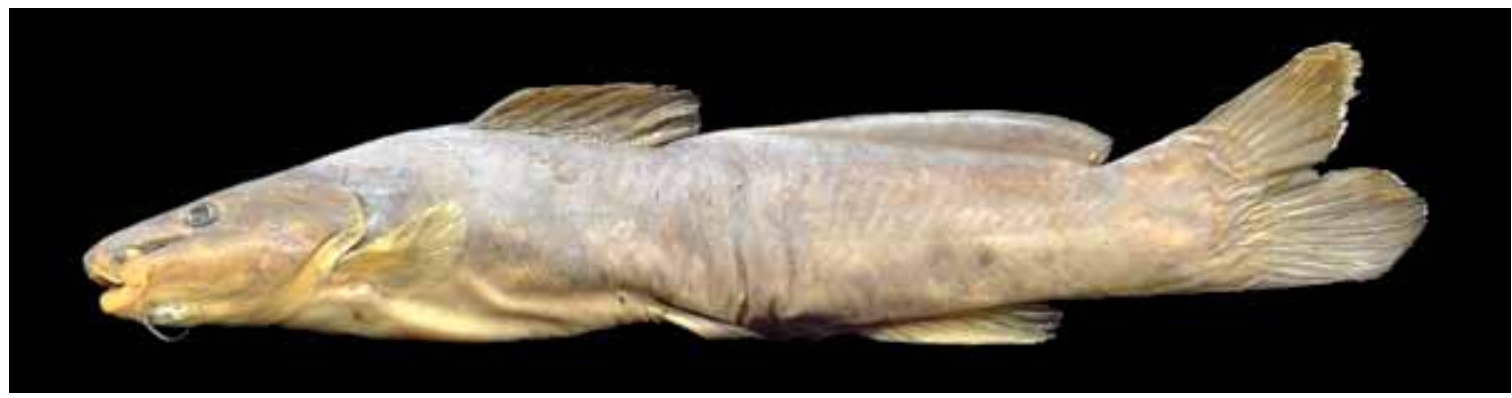

Comprimento padrão 360,0 mm

Corpo e nadadeiras cinzas, mais claro na região ventral. Corpo alongado, arredondado próximo à cabeça, comprimido na região da base da nadadeira adiposa, cabeça deprimida, adiposa longa e boca terminal.

Altura do corpo contida 3,9 a 4,2, do pedúnculo caudal 7,6 a 10,0, comprimento da cabeça 3,6 a 3,7, base da nadadeira anal 6,9 a 9,0 e base da nadadeira adiposa 2,9 a 3,4 vezes no CP. Comprimento do focinho contido 2,3 a 2,5, diâmetro orbital 5,8 a 6,9 e distância interorbital 2,9 a 3,4 vezes no CC.

Nadadeira dorsal com 7 a 9 raios, peitoral com 9 ou 10, pélvica com 6 e anal com 9 a 11 raios.

Essa espécie é considerada piscívora na região do baixo rio Iguaçu, podendo utilizar outros itens, como crustáceos do gênero Aegla (HAHN; FUGI; ALMEIDA; RUSSO; LOUREIRO, 1997. A reprodução ocorre entre setembro e março, mais intensamente entre outubro e dezembro, sendo que seus indivíduos iniciam a reprodução com $C P=112,0 \mathrm{~mm}$ nos machos e $C P=140,0 \mathrm{~mm}$ nas fêmeas (SUZUKI; AGOSTINHO, 1997).

A distribuição geográfica dessa espécie é restrita à bacia hidrográfica do rio Iguaçu, tendo sido registrada por Garavello, Pavanelli e Suzuki (1997), no reservatório de Segredo, por Universidade Estadual de Maringá (2002) no reservatório de Salto Caxias e por Baumgartner, Baumgartner, Pavanelli, Silva, Frana, Oliveira e Michelon (2006), nos reservatórios de Salto Santiago e Salto Osório. Essa espécie foi considerada como sinônima de Rhamdia quelen por Silfvergrip (1996), mas o autor não examinou material da bacia do rio Iguaçu. Considerando o endemismo da ictiofauna desta bacia e os estudos genéticos de Abucarma e Martins-Santos (2001), que apontaram diferenças cariotípicas entre as espécies desta bacia, $R$. branneri é aqui considerada como válida. 
- Rhamdia voulezi Haseman, 1911

Bagre, jundiá

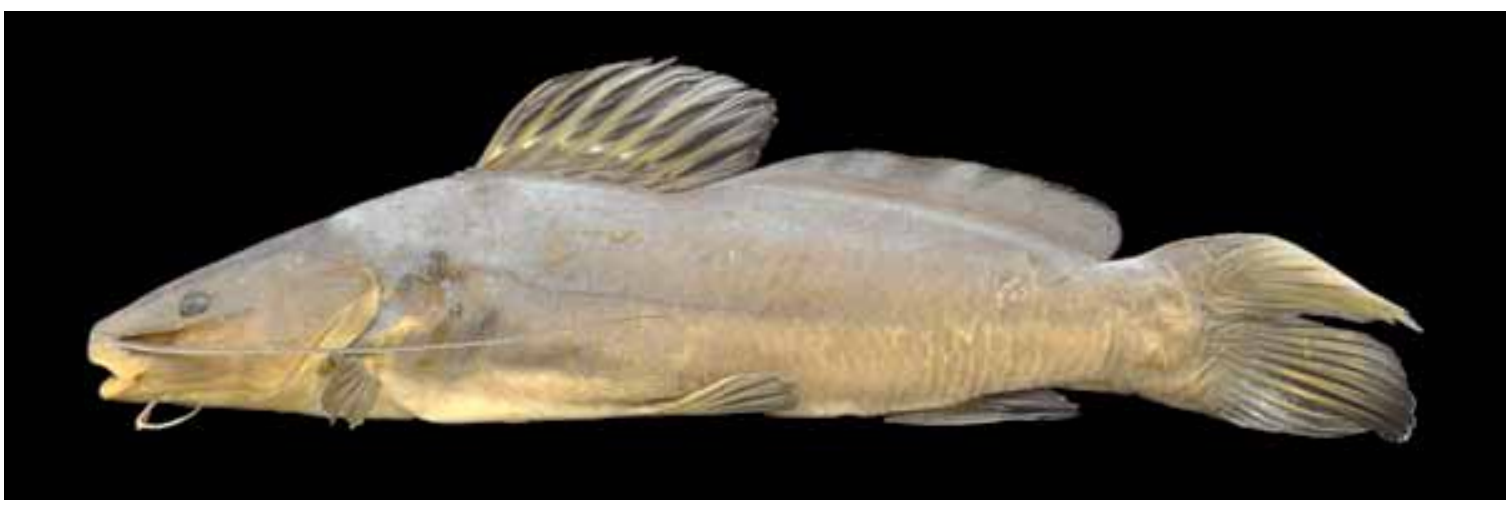

Comprimento padrão 320,0 mm
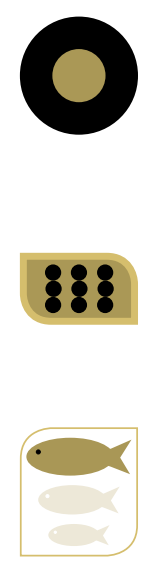

Corpo e nadadeiras cinzas, mais claro na região ventral. Corpo alongado, arredondado próximo à cabeça, comprimido na região da base da nadadeira adiposa, cabeça deprimida, adiposa longa e boca terminal.

Altura do corpo contida 4,1 a 5,4, do pedúnculo caudal 8,3 a 9,5, comprimento da cabeça 3,5 a 3,9, da base da nadadeira anal 6,8 a 8,8 e da base da nadadeira adiposa 2,5 a 3,0 vezes no CP. Comprimento do focinho contido 2,3 a 2,5, diâmetro orbital 4,9 a 7,0 e distância interorbital 2,6 a 3,5 vezes no CC.

Nadadeira dorsal com 7 a 9 raios, peitoral com 9 ou 10, pélvica com 6 e anal com 9 ou 10 raios.

Essa espécie é considerada piscívora na região do baixo rio Iguaçu, podendo utilizar outros itens, como crustáceos do gênero Aegla (HAHN; FUGI; ALMEIDA; RUSSO; LOUREIRO, 1997; UNIVERSIDADE ESTADUAL DO OESTE DO PARANÁ, 2006, 2008, 2009, 2010). A reprodução ocorre entre setembro e fevereiro, mais intensamente entre novembro e dezembro (SUZUKI; AGOSTINHO, 1997). Os menores indivíduos em atividade reprodutiva foram registrados com $C P=170,0 \mathrm{~mm}$ nas fêmeas e $C P=190,0$ $\mathrm{mm}$ nos machos (UNIVERSIDADE ESTADUAL DO OESTE DO PARANÁ, 2008b, 2009a, 2009b).

A distribuição geográfica dessa espécie é restrita à bacia hidrográfica do rio Iguaçu, tendo sido registrada em vários ambientes por Garavello, Pavanelli e Suzuki (1997), Universidade Estadual de Maringá (2002) e Baumgartner, Baumgartner, Pavanelli, Silva, Frana, Oliveira e Michelon (2006). Essa espécie foi considerada como sinônima de Rhamdia quelen por Silfvergrip (1996), mas o autor não examinou material da bacia do rio Iguaçu. Considerando o endemismo da ictiofauna desta bacia e os estudos genéticos de Abucarma e Martins-Santos (2001), que apontaram diferenças cariotípicas entre as espécies desta bacia, $R$. voulezi é aqui considerada como válida. 


\section{- Rhamdia sp.}

Bagre, jundiá

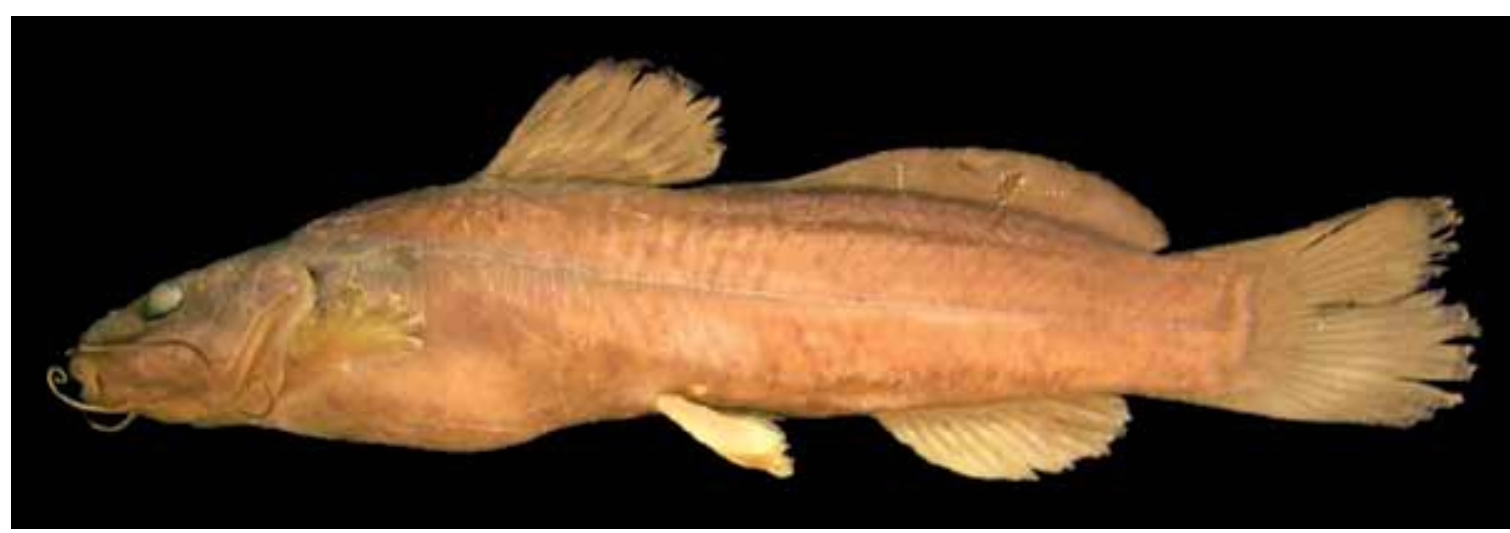

Comprimento padrão 114,7 mm

Corpo e nadadeiras marrom-acinzentados, mais claro na região ventral, com várias pintas marrons ao longo do corpo. Corpo alongado, arredondado próximo à cabeça, comprimido na região da base da nadadeira adiposa, a qual é longa, cabeça deprimida e boca terminal.

Altura do corpo contida 4,4 a 5,3, do pedúnculo caudal 7,5 a 8,6, comprimento da cabeça 3,8 a 4,2, da base da nadadeira anal 5,9 a 7,6 e da base da nadadeira adiposa 2,6 a 3,0 vezes no CP. Comprimento do focinho contido 2,4 a 2,6, diâmetro orbital 4,5 a 5,4 e distância interorbital 3,1 a 3,7 vezes no CC.

Nadadeira dorsal com 7 ou 8 raios, peitoral com 9 ou 10, pélvica com 6 e anal com 11 a 13 raios.

Essa espécie é considerada piscívora na região do baixo rio Iguaçu, podendo utilizar outros itens, como crustáceos do gênero Aegla (HAHN; FUGI; ALMEIDA; RUSSO; LOUREIRO, 1997; UNIVERSIDADE ESTADUAL DO OESTE DO PARANÁ, 2006). A distribuição geográfica dessa espécie provavelmente é restrita à bacia hidrográfica do rio Iguaçu, tendo sido registrada em vários ambientes por Garavello, Pavanelli e Suzuki (1997), Universidade Estadual de Maringá (2002) e Baumgartner, Baumgartner, Pavanelli, Silva, Frana, Oliveira e Michelon (2006). Estudos genéticos de Abucarma e Martins-Santos (2001) apontaram diferenças cariotípicas entre as espécies da bacia do rio Iguaçu, diferenciando esta espécie das duas outras congêneres. Espécie em estudo por Oscar Shibatta e Júlio Garavello. 


\section{FAMÍLIA}

\section{Ictaluridae}

Originária da América do Norte e Central, esta família é considerada de distribuição geográfica restrita, tendo sido trazida para o Brasil por seu potencial de cultivo. Os membros dessa família apresentam corpo alongado, desprovido de placas ou escamas, possuem quatro pares de barbilhões longos, incluindo um nasal, a nadadeira dorsal é localizada anteriormente e provida de um espinho vigoroso, e apresentam nadadeira adiposa (BURGESS, 1989).

\section{- Ictalurus punctatus (Rafinesque, 1818) Bagre-de-canal}

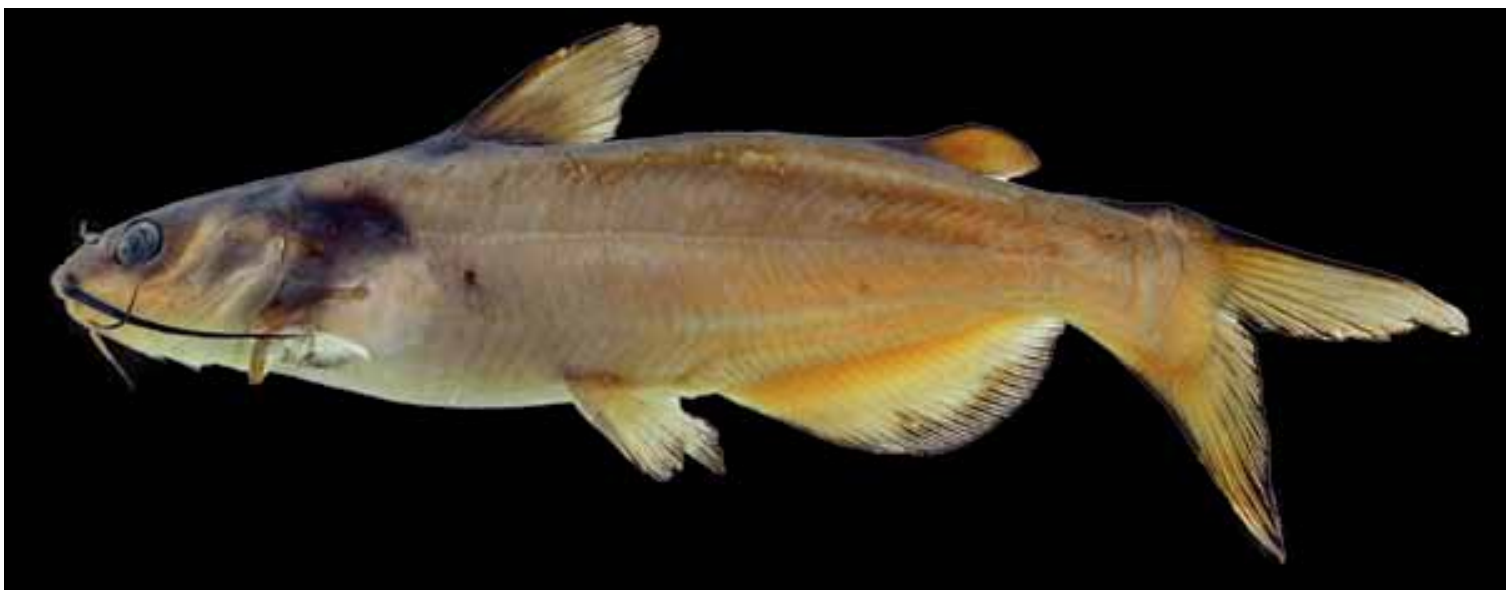

Comprimento padrão 180,5 mm

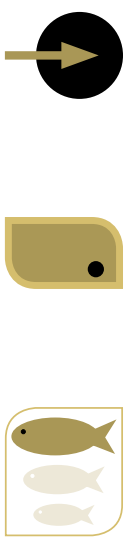

Corpo acinzentado, mais escuro na região dorsal e mais claro em direção ao ventre, tornando-se amarelado. Com pequenas pintas pretas geralmente distribuídas na lateral do corpo. Nadadeiras amareladas com extremidades pretas ou marrom-escuras, caudal bifurcada. Corpo alongado, comprimido e alto, cabeça larga e robusta, olhos grandes e boca subterminal.

Altura do corpo contida 4,5 a 4,8, do pedúnculo caudal 9,7 a 11,6, comprimento da cabeça 3,7 a 3,8, da base da nadadeira anal 3,1 a 3,3 e da base da nadadeira adiposa 12,6 a 16,4 vezes no CP. Comprimento do focinho contido 2,2 a 2,6, diâmetro orbital 4,0 a 5,8 e distância interorbital 2,3 a 3,1 vezes no CC.

Nadadeira dorsal com I+7 raios, peitoral com I+9, pélvica com 8 ou 9 e anal com 26 ou 27 raios.

Espécie nativa da América do Norte é raramente capturada no rio Iguaçu. Provavelmente, os espécimes capturados sejam provenientes de escapes de pisciculturas. 


\section{FAMÍLIA}

\section{Auchenipteridae}

Os Auchenipteridae reúnem exemplares de pequeno e médio porte, com dimorfismo sexual. Na maioria das vezes ocorre uma modificação na nadadeira anal, porém, em algumas espécies o dimorfismo pode ocorrer em outras partes do corpo, como nadadeira dorsal e barbilhões maxilares. Apresentam olho coberto por tecido adiposo, sem uma borda nítida, e a nadadeira adiposa é reduzida ou ausente (FERRARIS, 2003a). No baixo rio Iguaçu foram registrados apenas dois gêneros Glanidium e Tatia.

Os membros dessa família apresentam características reprodutivas diferenciadas dos demais bagres, com exceção de Scoloplax, da família Scoloplacidae. As fêmeas depois de inseminadas são capazes de manter os espermatozoides em "pacotes" no ovário por algum tempo antes de ocorrer a fecundação e desova (MENEZES; WEITZMAN; OYAKAWA; LIMA; CASTRO; WEITZMAN, 2007).

\section{- Glanidium ribeiroi Haseman, 1911} Bocudo

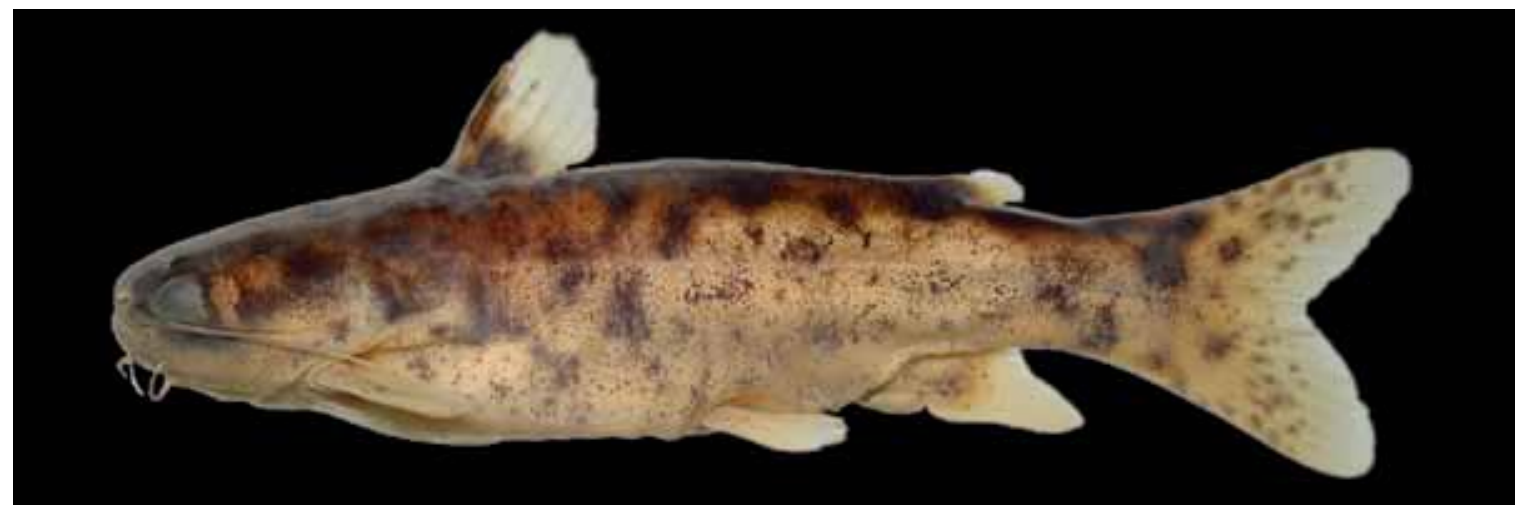

Comprimento padrão 79,0 mm

Corpo castanho na região dorsal, bege na região ventral, com manchas e pintas pretas distribuídas pela região dorsal e parte da lateral do tronco e cabeça, nadadeiras apresentando pintas escuras. Nadadeira caudal escura em alguns exemplares. Corpo curto, cabeça levemente deprimida e larga, coberta por pele espessa. Boca larga e terminal ou levemente prognata, dentes curtos, cônicos e dispostos em séries irregulares. Machos adultos com a nadadeira anal transformada em gonopódio.

Altura do corpo contida 4,5 a 5,0* e do pedúnculo caudal 8,1 a 9,4, comprimento da cabeça 3,5 a 3,8* , da base da nadadeira anal 14,9 a 17,6 (macho) e 9,4 a 12,3 (fêmea) vezes no $C P$. Comprimento do focinho contido 2,5 a 3,1, diâmetro orbital 5,5 a $6,3^{*}$ e distância interorbital 2,7 a 3,0 vezes no CC.

Nadadeira dorsal com $\mathrm{I}+5$ raios, peitoral com $\mathrm{I}+5$, pélvica com 5 e anal com 9 ou 10 raios.

Essa espécie alimenta-se principalmente de insetos (insetívora) e de peixes (piscívora) (HAHN; FUGI; ALMEIDA; RUSSO; LOUREIRO, 1997), podendo mudar seu hábito alimentar em função de alterações de habitat (represamento) (DELARIVA, 2002). O período reprodutivo estende-se de novembro a janeiro (UNIVERSIDADE ESTADUAL 
DE MARINGÁ, 2002), sendo que seus indivíduos iniciam a atividade reprodutiva com $\mathrm{CP}=75,0 \mathrm{~mm}$ nos machos e $\mathrm{CP}=95,0 \mathrm{~mm}$ nas fêmeas (SUZUKI; AGOSTINHO, 1997). A distribuição geográfica dessa espécie é restrita à bacia hidrográfica do rio Iguaçu (FERRARIS, 2003a).

- Tatia jaracatia Pavanelli \& Bifi, 2009

Bagre-sapo

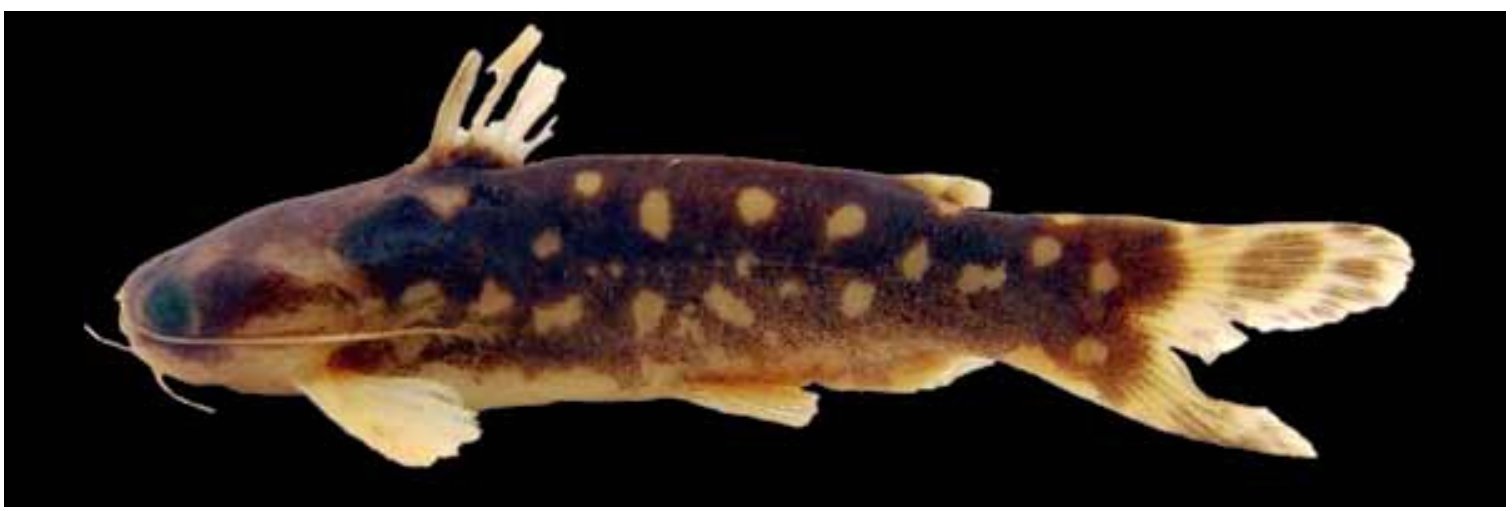

Comprimento padrão 52,2 mm

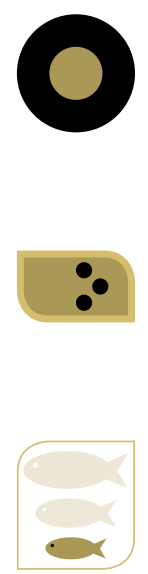

Corpo variando de castanho-claro a escuro, região ventral bege, com manchas brancas ou amarelo-claras, que podem ser grandes ou pequenas, redondas, difusas ou ovais, tanto em sentido longitudinal, quanto transversal, por toda a lateral do corpo. Nadadeira dorsal com poucos pigmentos escuros na porção mediana do primeiro e do segundo raio ramificado e nadadeira peitoral hialina. Nadadeira pélvica com pigmentação escura na região superior, concentrada próximo à base, assim como a nadadeira anal. Nadadeira caudal de uniformemente escura a com manchas escuras difusas ou ovais irregularmente distribuídas, podendo formar faixas. Alguns exemplares podem apresentar a nadadeira caudal uniformemente escura, sobretudo os jovens. Possui boca terminal e a nadadeira anal de machos adultos transformada em gonopódio.

Altura do corpo contida 3,7 a $5,0^{*}$, do pedúnculo caudal 6,0 a $7,6 *$, comprimento da cabeça 3,8 a $4,7^{*}$, da base da nadadeira anal 18,5 a $25,6^{*}$ (machos) e 9,2 a $12,3^{*}$ (fêmeas) vezes no CP. Comprimento do focinho contido 2,7 a 3,3*, diâmetro orbital 3,9 a 5,3* e distância interorbital 1,6 a 1,9* vezes no CC.

Nadadeira dorsal com $\mathrm{I}+5^{*}$ raios, peitoral com $\mathrm{I}+4^{*}$, pélvica com $6 *$ e anal com 9 raios.

Sua distribuição geográfica é restrita a bacia hidrográfica do rio Iguaçu.

*Pavanelli e Bifi (2009) 


\section{FAMÍLIA}

\section{Clariidae}

Originalmente da África, Síria, sul e sudeste da Ásia e das Filipinas, as espécies da família Clariidae foram introduzidas em diversos países (BURGESS, 1989), entre eles o Brasil. Os membros dessa família apresentam corpo alongado, desprovido de placas e escamas, nadadeira dorsal longa, mas separada da nadadeira anal e caudal, olhos laterais, geralmente quatro pares de barbilhões longos, e aparelho respiratório auxiliar, que lhes possibilita sobrevivência em baixas concentrações de oxigênio na água (BURGESS, 1989). No rio Iguaçu foi registrada somente uma espécie desta família, Clarias gariepinus.

\section{- Clarias gariepinus (Burchell, 1822)} Bagre-africano

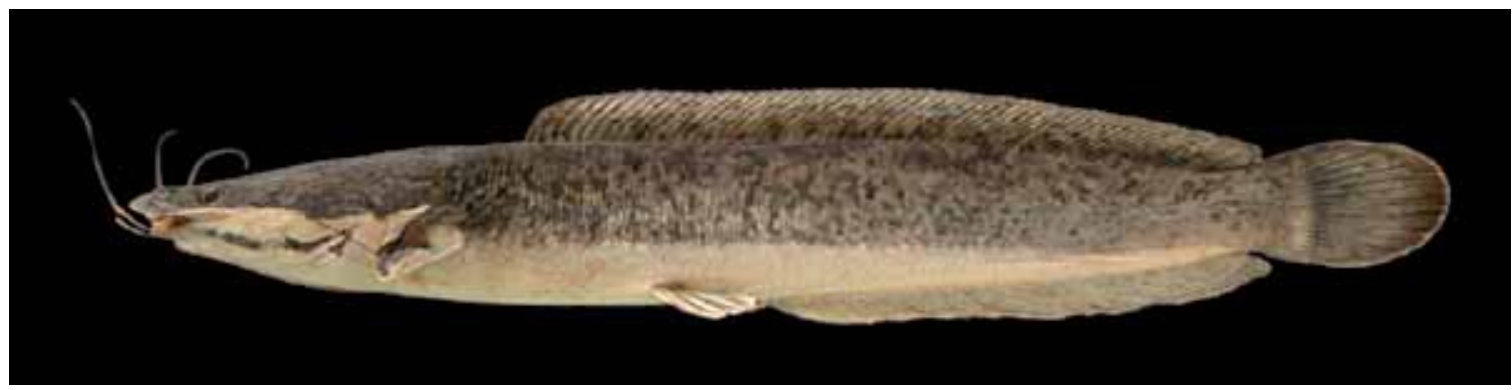

Comprimento padrão 329,0 mm

Corpo cinza-escuro na região dorso-lateral, branco na região ventro-lateral, uma faixa cinza-escura em cada um dos lados da superfície ventral da cabeça, às vezes ausente nos indivíduos jovens. Nadadeiras dorsal, anal e caudal escuras, nadadeiras peitoral e pélvica escuras na superfície dorsal e claras na superfície ventral. Nadadeira dorsal e anal longas, mas separadas da nadadeira caudal. Cabeça deprimida, olho pequeno, boca subterminal, quatro pares de barbilhões, incluindo um par nasal, e acúleo da nadadeira peitoral serrilhado anteriormente.

Altura do corpo contida 6,8 , do pedúnculo caudal 9,9 a $16,1^{*}$, comprimento da cabeça 2,9 a $3,8^{*}$, da base da nadadeira anal 2,1 a $2,7^{*}$ e da base da nadadeira dorsal 1,5 a $1,9 *$ vezes no CP. Comprimento do focinho contido 3,7 a 5,7*, diâmetro orbital 7,6 a $19,2^{*}$ e distância interorbital 2,2 a $2,7^{*}$ vezes no CC.

Nadadeira dorsal com 61 a $79^{*}$ raios, peitoral com I+9 a 12*, pélvica com 6* e anal com 45 a 60 * raios.

Esta espécie nativa da África e Ásia vem sendo esporadicamente capturada no baixo Iguaçu, provavelmente proveniente de escapes de pisciculturas.

*Hanssens (2009) 


\section{FAMÍLIA}

Algumas espécies dessa família podem atingir grande porte, com exemplares acima de 2 metros de comprimento, sendo muito apreciadas por pescadores, aquicultores e aquariofilistas. Devido ao uso em pisciculturas e pesque-pagues, algumas espécies dessa família têm sido introduzidas em novos ambientes, sendo desconhecidos atualmente os efeitos causados sobre a fauna nativa. Embora não apresentem um caráter externo que os diferencie dos demais siluriformes, os membros dessa família apresentam três pares de barbilhões (um maxilar e dois mentonianos), nadadeira adiposa bem desenvolvida (LUNDBERG; LITTMANN, 2003), abertura branquial ampla e canais látero-sensoriais cefálicos ramificados ou anastomosados na cabeça e parte anterior do corpo (SANTOS; MERONA; JURAS; JÉGU, 2004). Os membros dessa família são amplamente distribuídos pela região Neotropical (MENEZES; WEITZMAN; OYAKAWA; LIMA; CASTRO; WEITZMAN, 2007) e representados por 31 gêneros (SANTOS; MERONA; JURAS; JÉGU, 2004), porém no baixo rio Iguaçu, ocorrem apenas três, sendo Pimelodus e Steindachneridion com espécies nativas e Pseudoplatystoma com espécies introduzidas.

\section{Chave para espécies de Pimelodus}

1. Corpo com menos de seis séries de manchas longitudinais no flanco; olho pequeno, seu diâmetro contido 5,6 a 6,6 vezes no comprimento da cabeça

1'. Corpo com mais de sete séries de manchas longitudinais no flanco; olho grande, seu diâmetro contido 3,5 a 5,5 vezes no comprimento da cabeça 
- Pimelodus britskii Garavello \& Shibatta, 2007

Mandi-pintado, pintadinho

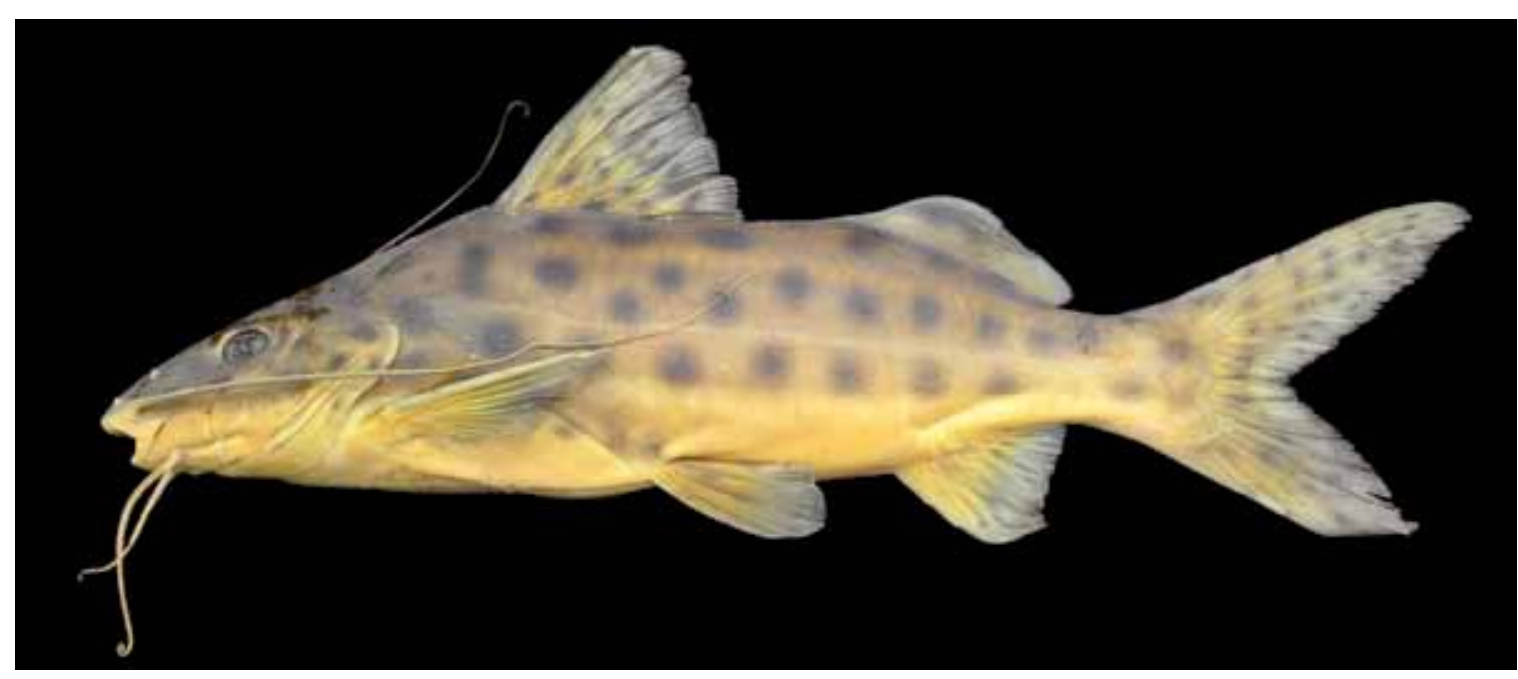

Comprimento padrão 195,0 mm

Corpo acinzentado nas regiões dorsal e lateral, com manchas pretas arredondadas, relativamente espaçadas entre si. Região ventral esbranquiçada e desprovida de manchas, nadadeiras acinzentadas com manchas pretas menores do que as do corpo. Corpo alto na base da nadadeira dorsal, região dorsal inclinada e levemente côncava desde a ponta do focinho até a origem da dorsal. Olho pequeno e boca terminal, ou levemente subterminal.

Altura do corpo contida 3,4 a 3,9, do pedúnculo caudal 9,3 a 11,5, comprimento da cabeça 3,2 a 3,6, da base da nadadeira anal 8,0 a 9,8 e da base da nadadeira adiposa 4,7 a 5,4 vezes no CP. Comprimento do focinho contido 1,9 a 2,2, diâmetro orbital 5,6 a 6,6 e distância interorbital 3,2 a 3,8 vezes no CC.

Nadadeira dorsal com I+6 raios, peitoral com I+10 ou 11, pélvica com 6 e anal com 9 a 11 raios.

Espécie amplamente capturada no baixo rio Iguaçu, apresenta hábito alimentar oportunista, tendo como item preferencial peixes em regiões represadas como os reservatórios, mas podendo consumir diversos itens principalmente na fase rio (UNIVERSIDADE ESTADUAL DO OESTE DO PARANÁ, 2006; DELARIVA; HAHN; GOMES, 2007; UNIVERSIDADE ESTADUAL DO OESTE DO PARANÁ, 2008b, 2009a, 2009b). Em algumas estações do ano, o ritmo alimentar dessa espécie intensifica-se no período crepuscular vespertino (UNIVERSIDADE ESTADUAL DE MARINGÁ, 2002).

Nos reservatórios de Salto Osório e Salto Santiago, a reprodução ocorre entre setembro e março, sendo que os menores indivíduos em atividade reprodutiva foram registrados com $C P=70,0 \mathrm{~mm}$ para fêmeas e $\mathrm{CP}=76,0 \mathrm{~mm}$ para machos (UNIVERSIDADE ESTADUAL DO OESTE DO PARANÁ, 2008b, 2009a, 2009b). No entanto, no reservatório de Salto Caxias foram observados exemplares em reprodução acima de $C P=165,0 \mathrm{~mm}$ nos machos e $\mathrm{CP}=194,0 \mathrm{~mm}$ nas fêmeas (UNIVERSIDADE ESTADUAL DE MARINGÁ, 2002), e no reservatório de Segredo, onde foi erroneamente identificada como $P$. ortmanni, com $C P=96,0 \mathrm{~mm}$ nos machos e $C P=165,0 \mathrm{~mm}$ nas fêmeas (SUZUKI; AGOSTINHO, 1997). 
A distribuição dessa espécie é restrita à bacia hidrográfica do rio Iguaçu (GARAVELLO; SHIBATTA, 2007). No livro sobre o reservatório de Segredo (AGOSTINHO; GOMES, 1997), esta espécie foi equivocadamente identificada como $P$. ortmanni, exceto no capítulo 4, de Garavello, Pavanelli e Suzuki (1997), onde foi chamada de Pimelodus sp.

\section{- Pimelodus ortmanni Haseman, 1911 Mandi}

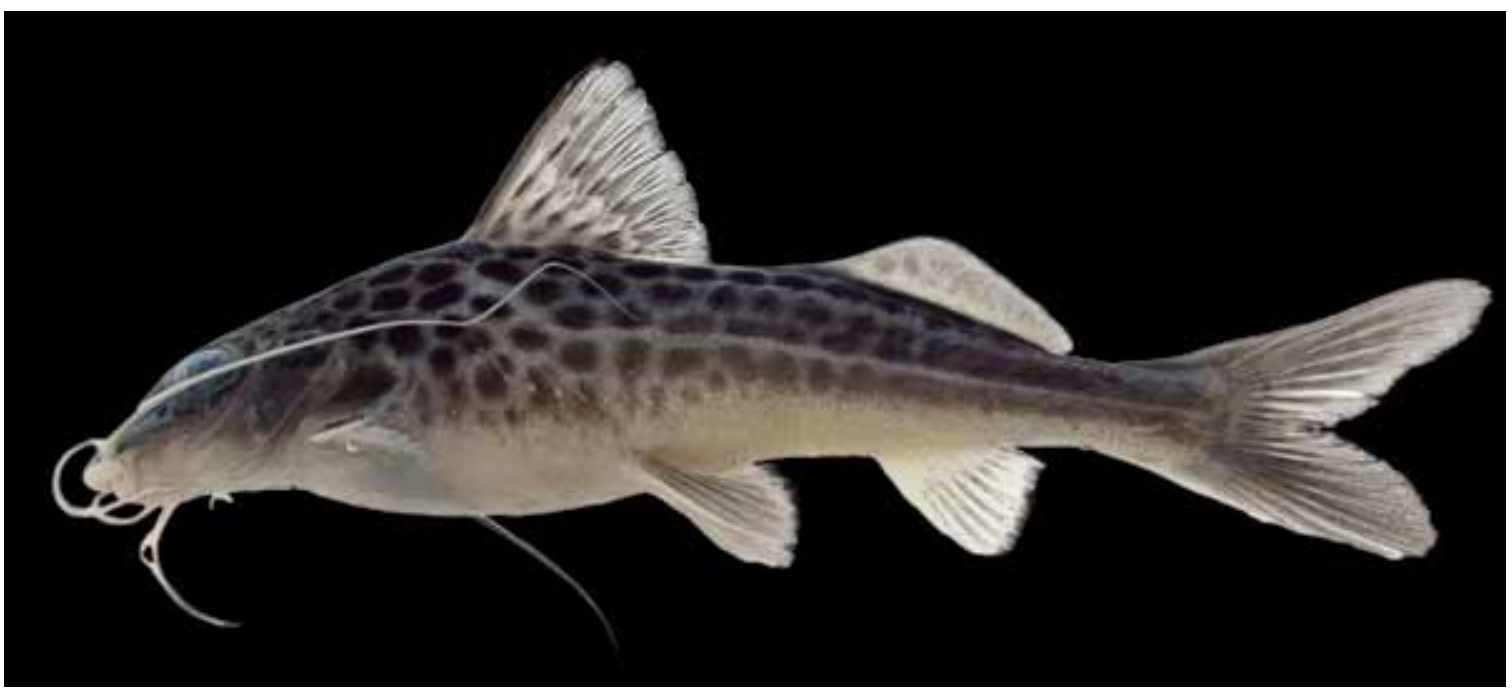

Comprimento padrão $118,0 \mathrm{~mm}$
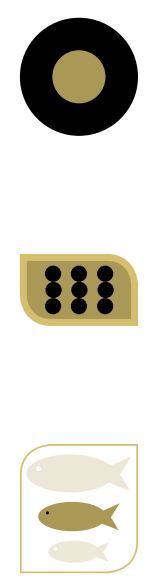

Corpo acinzentado nas regiões dorsal e lateral, com pequenas manchas pretas arredondadas ou ovaladas, muito próximas entre si, distribuídas sobre todo o corpo. Região ventral esbranquiçada e desprovida de manchas, nadadeiras acinzentadas com manchas pretas menores e menos conspícuas do que as do corpo, mais concentradas próximas às suas bases. Corpo relativamente baixo, região dorsal levemente convexa desde a ponta do focinho até a origem da dorsal. Olho grande e boca terminal, ou levemente subterminal.

Altura do corpo contida 3,5 a 4,9, do pedúnculo caudal 11,0 a 14,3 , comprimento da cabeça 3,4 a 3,9, da base da nadadeira anal 7,0 a 10,2 e da base da nadadeira adiposa 3,7 a 4,8 vezes no CP. Comprimento do focinho contido 1,9 a 2,2, diâmetro orbital 3,5 a 5,5 e distância interorbital 3,5 a 5,5 vezes no CC.

Nadadeira dorsal com I+6 raios, peitoral com I+9 a 11, pélvica com 6 e anal com 11 ou 12 raios.

No baixo rio Iguaçu, essa espécie é considerada insetívora (HAHN; FUGI; ALMEIDA; RUSSO; LOUREIRO, 1997; UNIVERSIDADE ESTADUAL DO OESTE DO PARANÁ, 2006). O período reprodutivo ocorre entre outubro e março, sendo que os indivíduos iniciam a atividade reprodutiva com $C P=88,0 \mathrm{~mm}$ nas fêmeas e $C P=76,0$ nos machos (UNIVERSIDADE ESTADUAL DO OESTE DO PARANÁ, 2008b, 2010). A distribuição geográfica dessa espécie é restrita à bacia hidrográfica do rio Iguaçu (GARAVELLO; SHIBATTA, 2007). No livro sobre o reservatório de Segredo (AGOSTINHO; GOMES, 1997), esta espécie foi identificada como Pimelodus sp., exceto no capítulo 4, de Garavello, Pavanelli e Suzuki (1997). 


\section{Chave para espécies de Pseudoplatystoma}

1. Corpo com várias manchas pretas arredondadas no flanco

P. corruscans

1'. Corpo com várias faixas pretas verticalmente alongadas e irregulares no flanco

$P$. reticulatum

- Pseudoplatystoma corruscans (Spix \& Agassiz, 1829)

Pintado

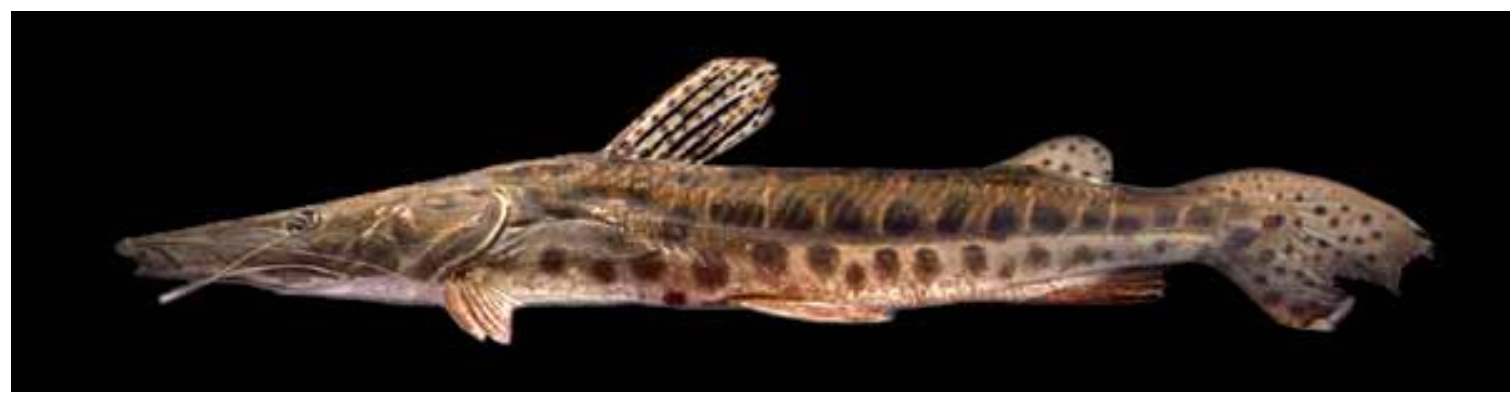

Comprimento padrão 315,0 mm

Corpo acinzentado na região dorsal, com manchas pretas arredondadas e irregulares. Região ventral esbranquiçada e desprovida de manchas, nadadeiras acinzentadas com manchas e pintas pretas menores que as do corpo. Corpo baixo, cabeça muito deprimida e perfil ventral reto. Olho médio e boca ampla e terminal, ou levemente subterminal.

Altura do corpo contida 5,7 a 6,4, do pedúnculo caudal 14,9 a 16,5, comprimento da cabeça 2,6 a 2,7, da base da nadadeira anal 8,8 a 8,9 e da base da nadadeira adiposa 10,7 a 11,8 vezes no CP. Comprimento do focinho contido 2,0 a 2,1, diâmetro orbital 10,3 a 11,4 e distância interorbital 4,3 a 4,8 vezes no CC.

Nadadeira dorsal com 7 raios, peitoral com I+8 ou 9, pélvica com 6 e anal com 13 a 15 raios.

Na planície do alto rio Paraná, essa espécie apresenta hábito alimentar essencialmente piscívoro (HAHN; FUGI; LOUREIRO-CRIPPA; PERETTI; RUSSO, 2004). Distribui-se amplamente nas bacias do Paraná, Paraguai e São Francisco, onde é nativa (BUITRAGO-SUÁREZ; BURR, 2007). Na bacia do rio Iguaçu sua ocorrência é esporádica, sendo que os espécimes encontrados são adultos e provavelmente provenientes de tanques de piscicultura da região ou transposições deliberadas. 
- Pseudoplatystoma reticulatum Eigenmann \& Eigenmann, 1889 Cachara

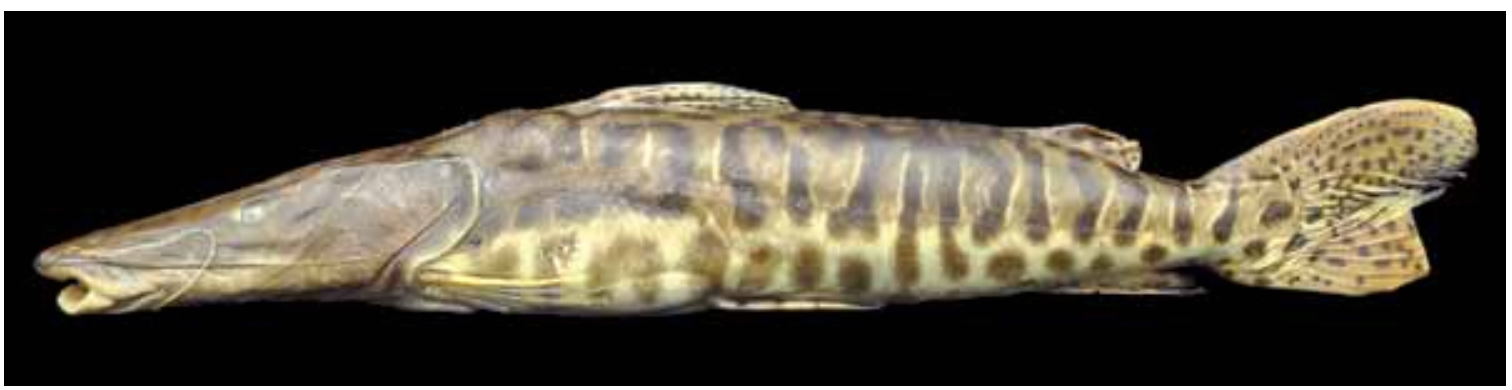

Comprimento padrão 440,0 mm

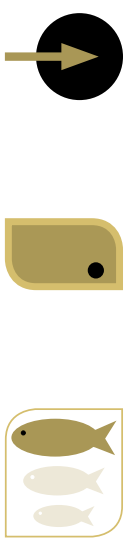

Corpo acinzentado na região dorsal, com faixas pretas transversalmente alongadas e irregulares. Região ventral esbranquiçada e desprovida de manchas, nadadeiras esbranquiçadas com pequenas manchas e pintas pretas. Corpo baixo, cabeça muito deprimida e perfil ventral reto. Olho médio e boca ampla e terminal, ou levemente subterminal.

Altura do corpo contida 5,8 a 6,9, do pedúnculo caudal 15,1 a 15,3, comprimento da cabeça 2,5 a 2,7, da base da nadadeira anal 8,9 a 9,0 e da base da nadadeira adiposa 11,2 a 11,3 vezes no CP. Comprimento do focinho contido 1,9 a 2,0, diâmetro orbital 10,7 a 12,8 e distância interorbital 4,3 a 4,6 vezes no CC.

Nadadeira dorsal com 7 raios, peitoral com I+9, pélvica com 6 e anal com 13 ou 14 raios.

Essa espécie é amplamente distribuída nas bacias do Paraná, Paraguai e Amazonas, onde é nativa (BUITRAGO-SUÁREZ; BURR, 2007). Na bacia do rio Iguaçu sua ocorrência é esporádica, sendo que os espécimes capturados são provavelmente provenientes de tanques de piscicultura ou transposições deliberadas. 


\section{- Steindachneridion melanodermatum Garavello, 2005 Surubim-do-Iguaçu, monjolo}

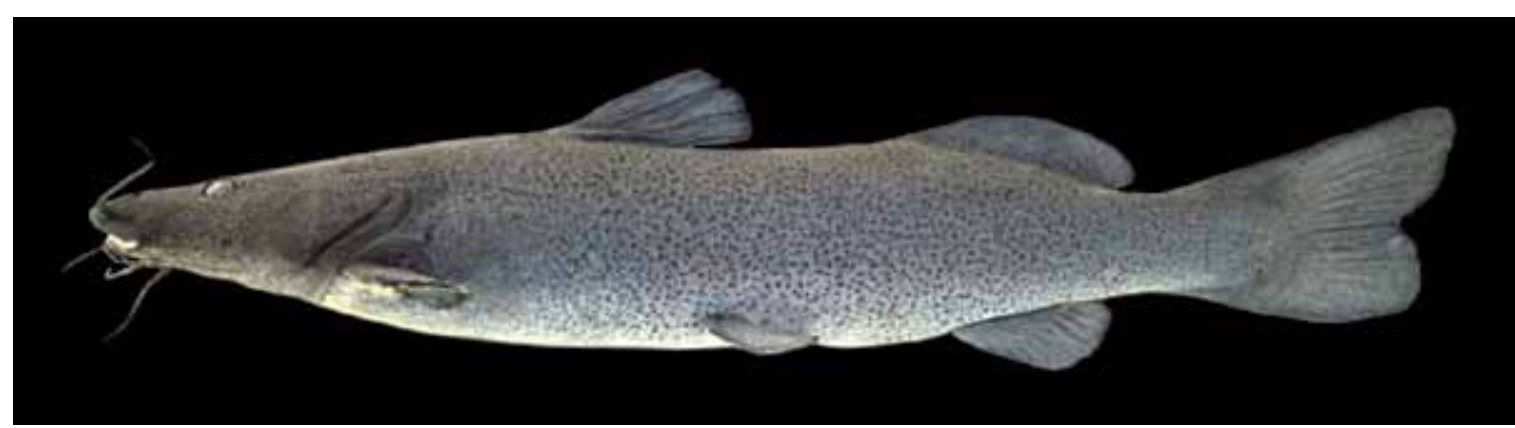

Comprimento padrão 347,0 mm

Cabeça e tronco marrons ou cinza-escuros, com pintas pretas nas regiões dorsal e lateral. Região ventral cinza-clara. Nadadeiras com padrão de coloração semelhante ao do corpo, sendo mais escuras nas bordas. Cabeça deprimida, lábios bem desenvolvidos, barbilhão maxilar curto, pedúnculo caudal alto e comprimido, corpo alongado, boca terminal, ou levemente subterminal.

Altura do corpo contida 4,1 a 4,4, do pedúnculo caudal 10,4 a $11,1^{*}$, comprimento da cabeça 3,4 a 3,5* da base da nadadeira anal 8,4 a 8,6 e da base da nadadeira adiposa 4,8 a 5,7* vezes no CP. Comprimento do focinho contido 2,3 a 2,4, diâmetro orbital 10,4 a $11,6^{*}$ e distância interorbital 2,8 a 3,2* vezes no CC.

Nadadeira dorsal com 7 ou $8^{*}$ raios, peitoral com 10 ou $11^{*}$, pélvica com $6^{\star}$ e anal com 9 ou $10 *$ raios.

É o grande "bagre" do rio Iguaçu, sendo capturado principalmente em trechos onde o fluxo natural do rio é ainda preservado (GARAVELLO, 2005). Sua distribuição geográfica é restrita à bacia do rio Iguaçu (GARAVELLO; SHIBATTA, 2007). Embora não conste em listas oficiais de espécies ameaçadas, sua ocorrência naturalmente rara e associada a ambientes de águas rápidas (GARAVELLO, 2005) deve ser considerada na elaboração de futuras listas, sobretudo considerando que estes ambientes têm sido restringidos pela cascata de reservatórios estabelecida na bacia. 


\section{Ordem}

\section{GYMNOTIFORMES}
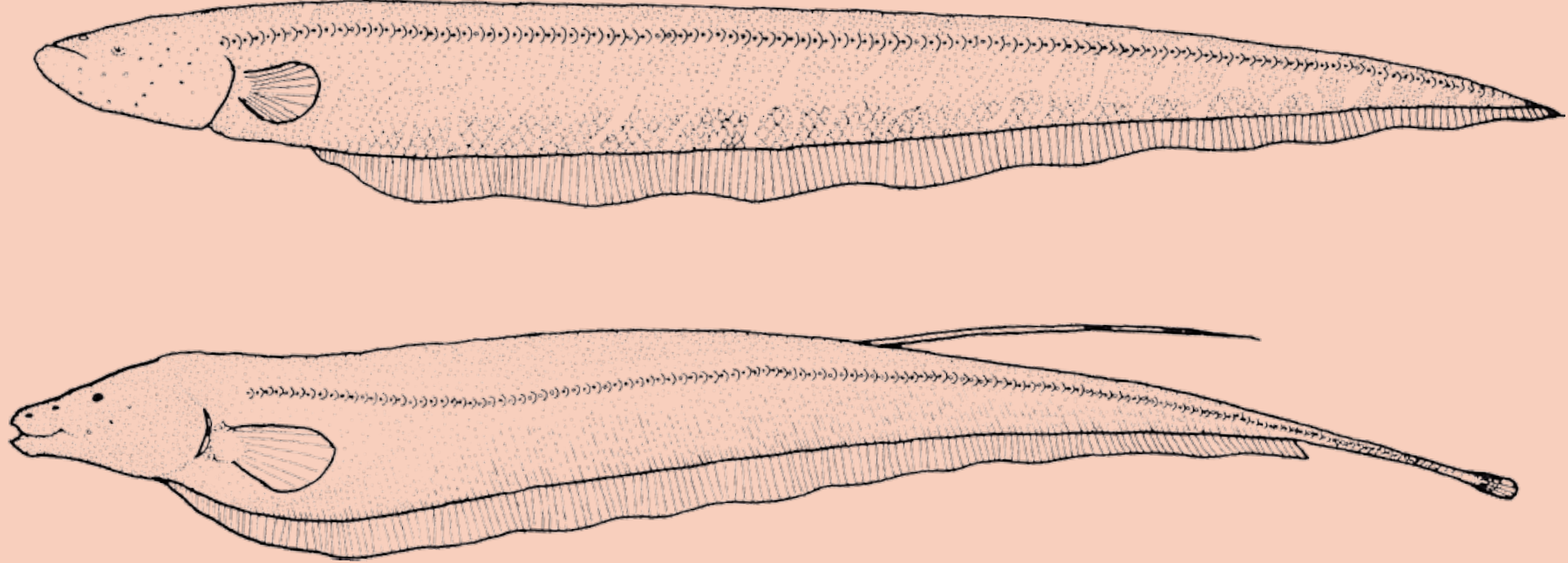

Os representantes desta ordem apresentam diversas adaptações que os diferenciam muito dos demais grupos de peixes, como o corpo muito comprimido e alongado, em forma de faca, ausência de nadadeira dorsal e nadadeira anal extremamente longa, conferindo a eles a capacidade de natação para trás. Além disso, possuem orgãos elétricos que permitem a emissão de pulsos elétricos que são utilizados em diversas situações a que são submetidos, os quais são diferentes para cada espécie. Nenhum representante desta ordem é nativo da bacia do rio Iguaçu e suas ocorrências podem ser atribuídas ao fato de tradicionalmente algumas espécies serem utilizadas como iscas vivas. 
FAMÍLIAS

Gymnotidae

Apteronotidae 


\section{FAMÍLIA}

Com apenas dois gêneros, esta família caracteriza-se por apresentar corpo comprimido e longo, nadadeiras pélvica, dorsal e caudal ausentes e nadadeira anal longa. Este grupo é capaz de produzir descargas elétricas e de utilizar oxigênio atmosférico (CAMPOS-DA-PAZ, 1997). Duas espécies de Gymnotus foram capturadas na bacia do rio Iguaçu a partir de 1994 (SEVERI; CORDEIRO, 1994), quando foram identificadas como G. carapo. A despeito de não serem nativas, têm sido capturadas no rio Iguaçu devido à sua grande utilização como iscas vivas na pesca.

\section{Chave para espécies de Gymnotus}

1. Faixas transversais castanho-escuras mais largas do que as interfaixas claras, em exemplares maiores do que $150,0 \mathrm{~mm}$; cabeça curta, seu comprimento contido 8,1 a 12,2 vezes no comprimento total, e alta, sua altura contida 1,4 a 1,6 vezes no seu comprimento

G. inaequilabiatus

1'. Faixas transversais castanho-escuras mais estreitas do que as interfaixas claras, em exemplares maiores do que $150,0 \mathrm{~mm}$; cabeça longa, seu comprimento contido 7,1 a 8,1 vezes no comprimento total, e baixa, sua altura contida 1,6 a 1,7 vezes no seu comprimento

- Gymnotus inaequilabiatus (Valenciennes, 1839)

Morenita, tuvira

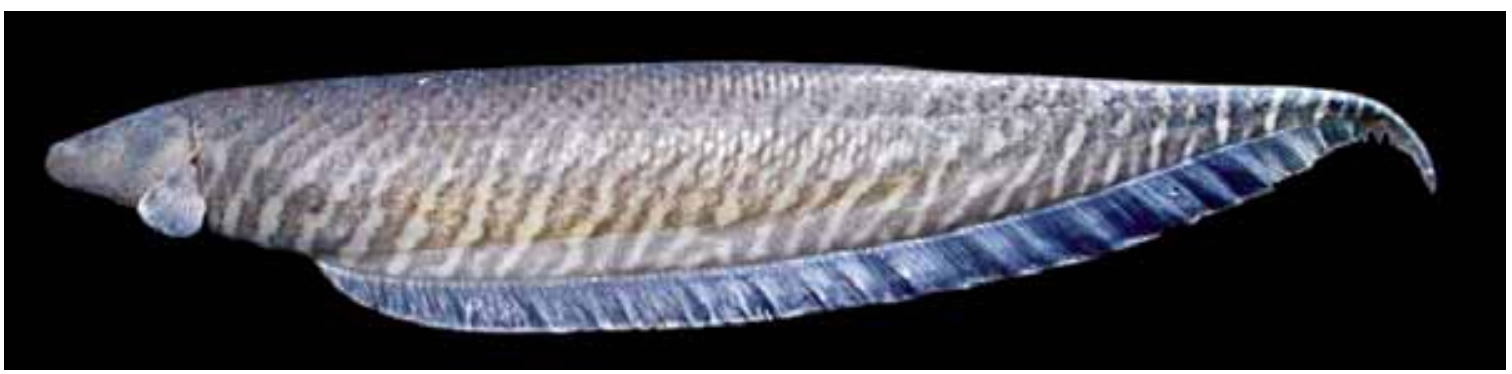

Comprimento padrão $134,0 \mathrm{~mm}$

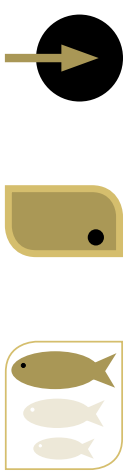

Corpo com faixas esbranquiçadas e marrom-escuras alternadas, sendo as claras mais estreitas que as escuras. Podem apresentar pintas pretas na região dorsal. Corpo alongado, mandíbula prognata, boca superior e nadadeira anal preta ou pelo menos mais escura do que as faixas escuras do corpo.

Altura do corpo contida 8,3 a 13,3*, comprimento da cabeça 8,1 a $12,2^{*}$ e da base da nadadeira anal 1,2 a $1,3^{*}$ vezes no $C T$. Altura da cabeça contida 1,4 a $1,6^{*}$, comprimento da nadadeira peitoral 2,0 a $2,7^{*}$, comprimento do focinho 2,6 a $3,2^{*}$, pré-anal 1,1 a $1,5^{*}$, distância interorbital 2,2 a $2,7^{*}$ e largura da boca 2,1 a 2,5* vezes no CC.

Nadadeira peitoral de borda arredondada, com 13 a 16* raios, anal com 170 a 260* raios totais, e 6 a 9* séries de escamas acima da linha lateral. 
Essa espécie é encontrada nas bacias dos rios Paraná e Paraguai e áreas adjacentes (CAMPOS-DA-PAZ; BUCKUP, 2007). Possivelmente introduzida na bacia do rio Iguaçu por sua ampla utilização como isca viva por pescadores provenientes de outras bacias hidrográficas.

*Albert e Crampton (2003)

\section{- Gymnotus sylvius Albert \& Fernandes-Matioli, 1999} Morenita, tuvira

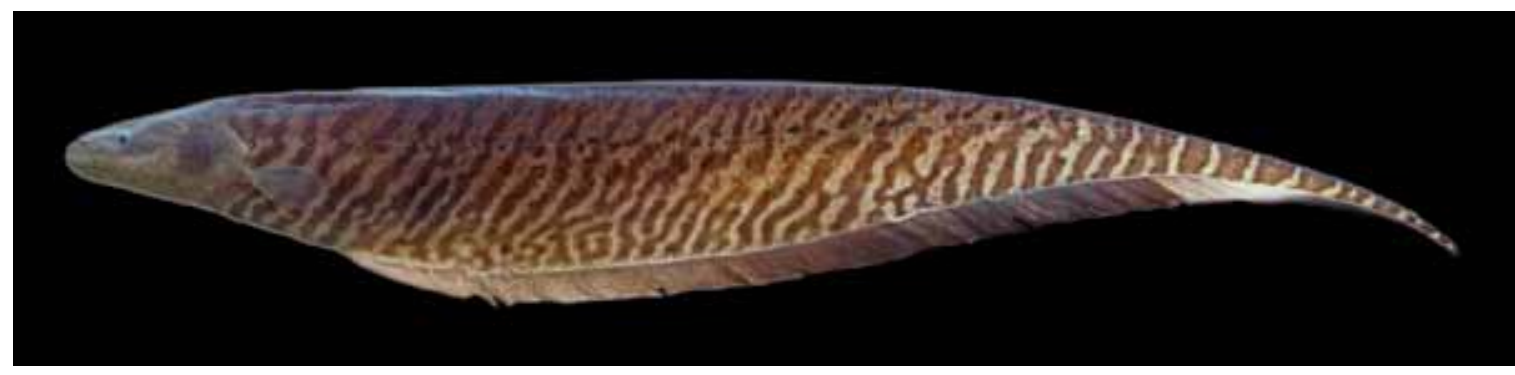

Comprimento padrão $175,4 \mathrm{~mm}$

Corpo com faixas esbranquiçadas e marrom-escuras alternadas, sendo as escuras mais estreitas que as claras. Apresenta corpo alongado, mandíbula prognata, boca superior e nadadeira anal preta ou pelo menos mais escura do que as faixas escuras do corpo.

Altura do corpo contida 7,6 a 9,7*, comprimento da cabeça 7,1 a $8,1^{*}$, e da base da nadadeira anal 1,2 a $1,3^{*}$ vezes no $C T$. Altura da cabeça contida 1,6 a $1,7^{*}$, comprimento da nadadeira peitoral 2,1 a $2,4^{*}$, comprimento do focinho 2,8 a $2,9 *$, pré-anal 1,5 a 2,1* distância interorbital 2,6 a 2,7* e largura da boca 2,5 a 3,1* vezes no CC.

Nadadeira peitoral de borda arredondada, com 16 raios, anal com 220 a 230* raios totais e $8^{*}$ séries de escamas acima da linha lateral.

Essa espécie é encontrada nas bacias dos rios Ribeira de Iguape, Paraíba do Sul, Pardo (CAMPOS-DA-PAZ; BUCKUP, 2007), do rio Paraguai (ALBERT; CRAMPTON, 2003), e bacia do alto rio Paraná (GRAÇA; PAVANELLI, 2007). Possivelmente introduzida na bacia do rio Iguaçu por sua ampla utilização como isca viva por pescadores provenientes de outras bacias hidrográficas.

*Albert e Crampton (2003)

\section{Apteronotidae}

Família composta por 13 gêneros, no entanto apenas Apteronotus foi capturado na bacia do rio Iguaçu. Possuem corpo alongado, nadadeira anal longa, nadadeira caudal presente, filamento carnoso médio-dorsal presente e perfil ventral de convexo a reto (CAMPOS-DA-PAZ, 1997). Assim como as de Gymnotidae, espécies dessa família não são nativas da bacia do rio Iguaçu. 


\section{Chave para espécies de Apteronotus}

1. Corpo alto, sua altura contida 5,8 a 6,2 no comprimento do focinho até a nadadeira anal; cabeça curta, seu comprimento contido 5,9 a 6,5 vezes no comprimento do focinho até a nadadeira anal; focinho curto, seu comprimento contido 2,6 a 3,0 no comprimento da cabeça; olho grande, contido 12,7 a 18,2 vezes no comprimento da cabeça; escamas grandes, 5 a 8 séries longitudinais acima da linha lateral

1'. Corpo baixo, sua altura contida 6,7 a 8,1 no comprimento do focinho até a nadadeira anal; cabeça longa, seu comprimento contido 3,6 a 5,3 vezes no comprimento do focinho até a nadadeira anal; focinho longo, seu comprimento contido 1,9 a 2,2 no comprimento da cabeça; olho pequeno, contido 20,0 a 31,3 vezes no comprimento da cabeça; escamas pequenas, 11 a 15 séries longitudinais acima da linha lateral

\section{- Apteronotus ellisi (Arámburu, 1957)}

Ituí-cavalo

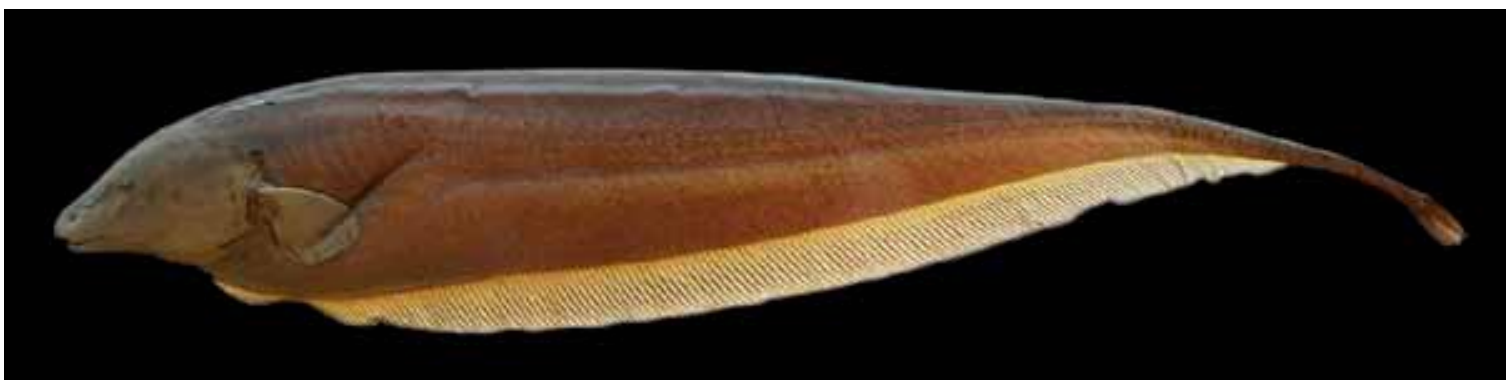

Comprimento padrão 175,0 mm

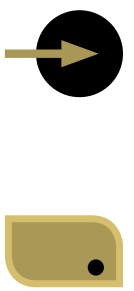

Corpo castanho, mais escuro na região dorsal e clareando em direção à região ventral, nadadeira anal e caudal castanhas com pigmentos pretos dispersos. Corpo alongado e comprimido. Cabeça curta e boca terminal, ou levemente subterminal.

Altura do corpo contida 5,8 a 6,2* , comprimento da cabeça 5,9 a 6,5*, base da nadadeira anal 1,1 a $1,2^{*}$, da nadadeira caudal 6,2 a $7,8^{*}$, pré-peitoral 5,4 a $5,7^{*}$ e pré-anal 5,8 a 7,2* vezes no CFA. Comprimento do focinho contido 2,6 a 3,0*, diâmetro orbital 12,7 a $18,2 *$ e distância interorbital 3,9 a 5,0* vezes no CC.

Nadadeira peitoral com 16 ou $17^{*}$ raios, anal com 17 a $25^{*}$ raios anteriores inteiros e 153 a $165^{*}$ raios totais, caudal com 17 a $20^{*}$ raios, e 5 a $8^{*}$ séries de escamas acima da linha lateral.

Essa espécie é distribuída pelas bacias do Paraná e Paraguai, segundo Graça e Pavanelli (2007), que identificaram esta espécie como Porotergus ellisi. Foi provavelmente introduzida na bacia do rio Iguaçu, onde é capturada de maneira esporádica.

*Campos-da-Paz (1997) 


\section{- Apteronotus sp.}

\section{Ituí-cavalo}

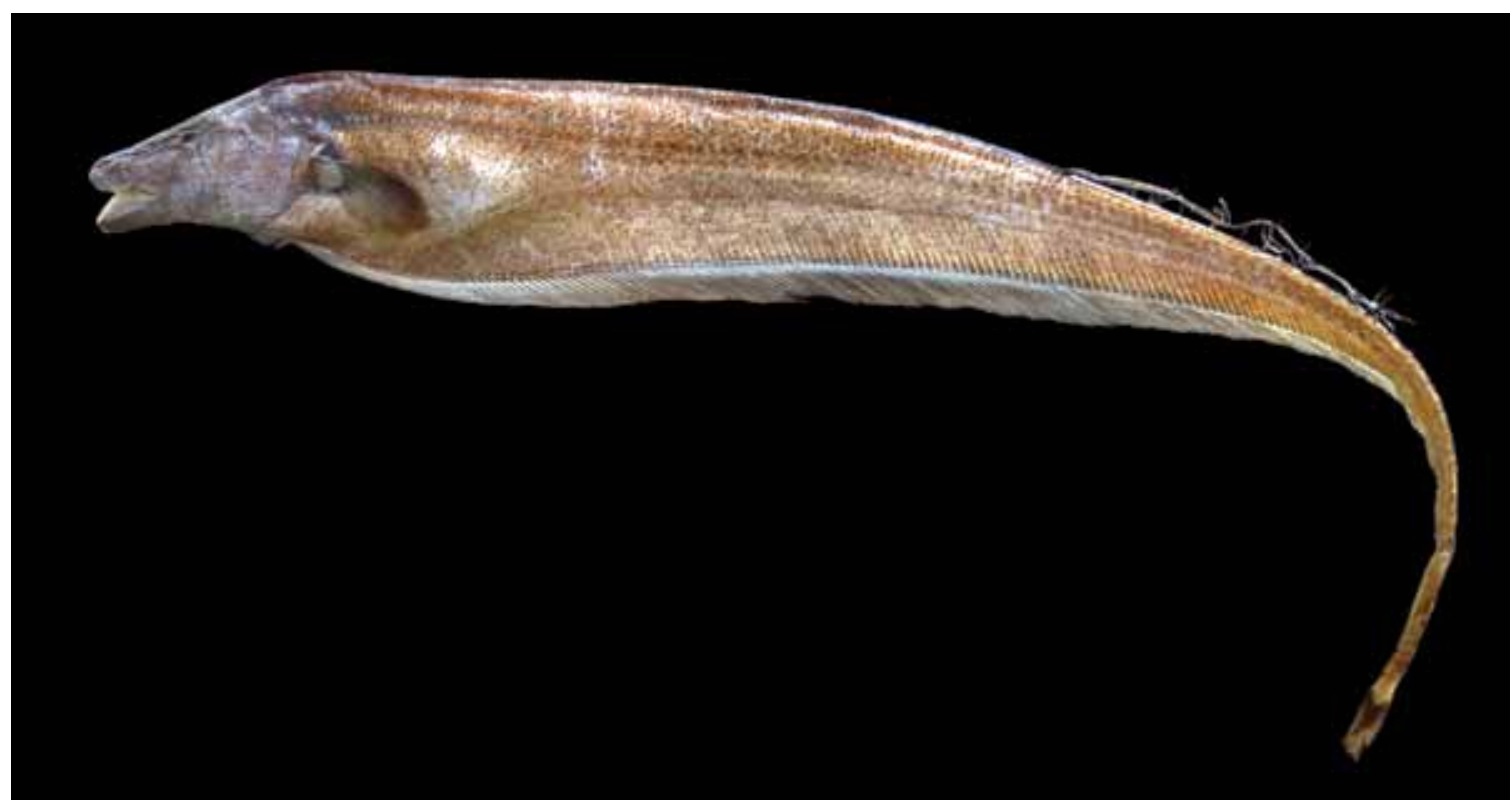

Comprimento padrão $277,8 \mathrm{~mm}$

Corpo castanho, mais escuro na região dorsal e cabeça, nadadeira peitoral, anal e caudal mais escuras. Corpo alongado e comprimido. Cabeça longa e boca terminal.

Altura do corpo contida 6,7 a $8,1^{*}$, comprimento da cabeça 3,6 a 5,3*, base da nadadeira anal 1,2 a $1,3^{*}$, da nadadeira caudal 7,4 a 9,6, pré-peitoral 6,3 a 7,6* e pré-anal 5,3 a $6,7^{*}$ vezes no CFA. Comprimento do focinho contido 1,9 a 2,2*, diâmetro orbital 20,0 a $31,3^{*}$ e distância interorbital 5,5 a 7,6* vezes no CC.

Nadadeira peitoral com 16 a 19* raios, anal com 19 a $25^{*}$ raios anteriores inteiros e 163 a $178^{*}$ raios totais, caudal com 17 a 20* raios, e 11 a 15* séries de escamas acima da linha lateral.

Apenas um exemplar desta espécie foi capturado na bacia do rio Iguaçu, sendo semelhante à Apteronotus sp. encontrada na bacia do rio Paraná, onde ocorre naturalmente (GRAÇA; PAVANELLI, 2007) e provavelmente foi introduzida na bacia do rio Iguaçu, onde raramente é coletada.

\footnotetext{
*Campos-da-Paz (1997)
} 


\section{Ordem}

ATHERINIFORMES

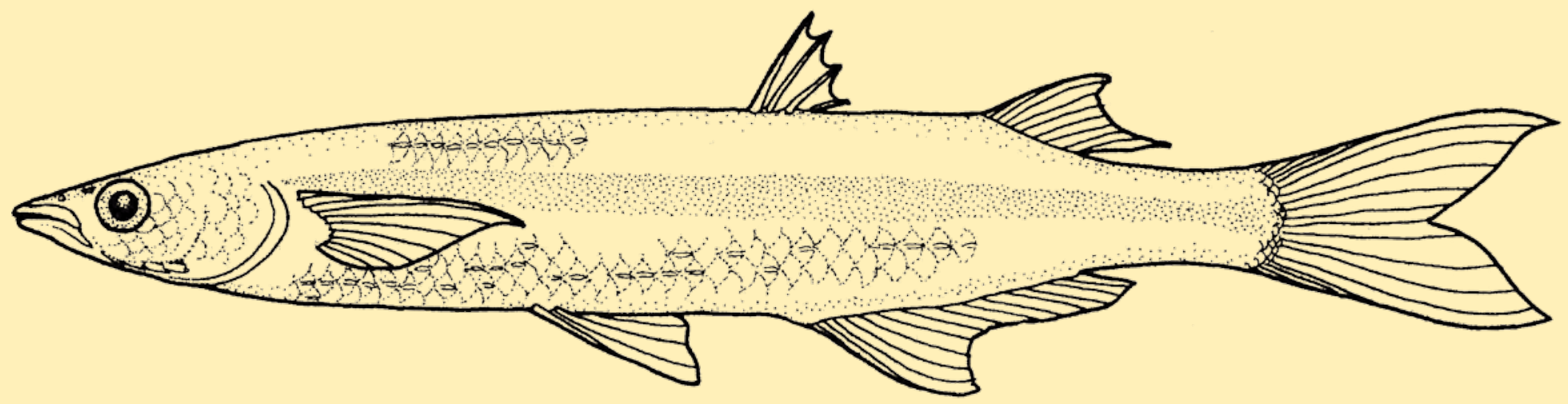

Esta ordem possui representantes predominantemente marinhos, com alguns representantes habitando águas salobras ou deltas de rios, e poucos exclusivamente de água doce, como é o caso da espécie que ocorre no rio Iguaçu. Apresentam o corpo fusiforme, cabeça achatada superiormente e geralmente duas nadadeiras dorsais. 


\section{FAMIÍLIA}

Atherinopsidae 


\section{FAMÍLIA}

\section{Atherinopsidae}

Naturalmente encontrados em águas temperadas e com a maioria de suas espécies sendo marinhas, os Atherinopsidae são diferenciados de outras famílias por apresentarem duas nadadeiras dorsais largamente separadas, a primeira com espinho flexível e a segunda com um espinho seguido por raios moles (NELSON, 2006). Apresentam nadadeira anal com um espinho seguido por raios moles, nadadeira peitoral relativamente alta, boca de pequena a média, terminal ou subterminal, pré-maxila protrátil, duas linhas laterais e uma faixa longitudinal na lateral do corpo prateada em vida e escura em indivíduos preservados (DYER, 2003).

\section{- Odontesthes bonariensis (Valenciennes, 1835)} Peixe-rei

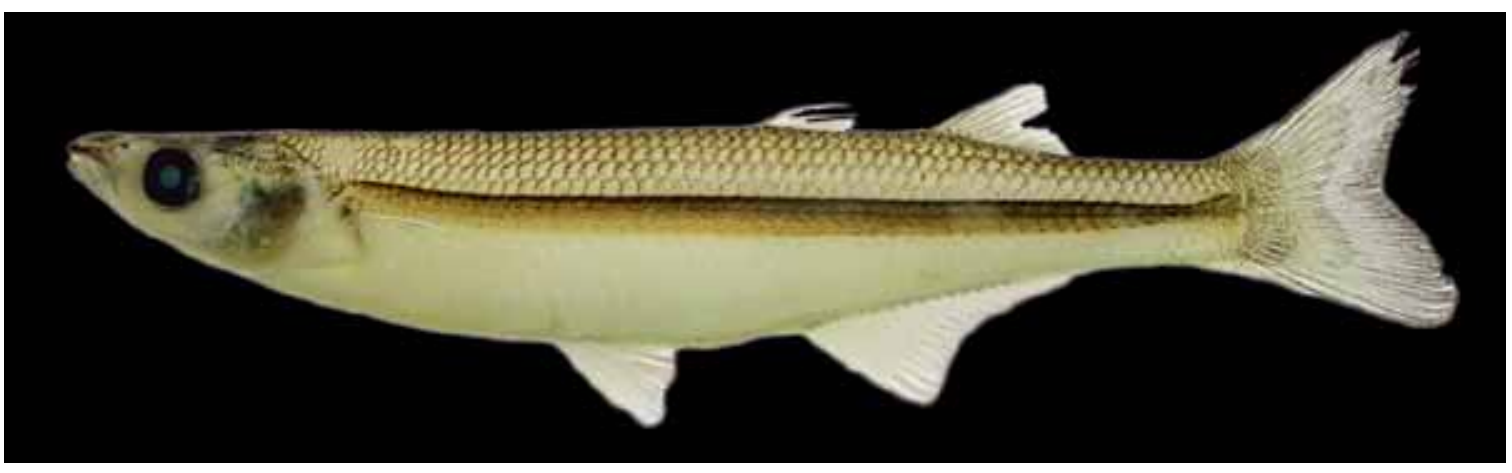

Comprimento padrão 102,2 mm

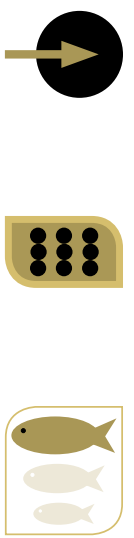

Corpo amarelado, uma faixa longitudinal cinza-escura na lateral do corpo (prateada em vida), mancha cinza-escura na região occipital, nadadeiras claras, sendo a pélvica, dorsal e caudal com pigmentos escuros dispersos. Corpo fusiforme e alongado, cabeça deprimida e boca terminal.

Altura da cabeça contida 5,9 a $8,3^{*}$, do pedúnculo caudal 14,1 a $10,5^{*}$ e comprimento da cabeça 3,5 a 4,3* vezes no CP. Comprimento do focinho 2,7 a 3,2* diâmetro orbital 5,9 a 8,1* e distância interorbital 3,3 a 4,1* vezes no CC.

Nadadeiras dorsal anterior com 4 a $6^{*}$ raios, posterior com 8 a 11*, pélvica com 6, anal com 15 a $19 *$ e peitoral com 12 a $15^{*}$ raios. Possui linha lateral dupla e muito irregular, sendo a menor localizada acima da faixa longitudinal e a maior abaixo, 50 a 59* escamas na linha longitudinal.

No reservatório de Segredo seu principal item alimentar foi microcrustáceos (HAHN; FUGI; ALMEIDA; RUSSO; LOUREIRO, 1997), enquanto no reservatório de Salto Caxias foi insetívora antes do represamento e planctívora após, sendo que em alguns locais deste reservatório a espécie apresentou hábito piscívoro (DELARIVA, 2002). Seu período reprodutivo ocorre de maio a setembro, com maior intensidade em julho, sendo que os menores indivíduos em atividade reprodutiva foram registrados com $C P=135,0 \mathrm{~mm}$ nas fêmeas e $C P=132,0 \mathrm{~mm}$ nos machos (UNIVERSIDADE ESTADUAL DO OESTE DO PARANÁ, 2008b, 2009b, 2010). 
Sua distribuição geográfica abrange principalmente a bacia do rio da Prata, sul da Argentina e Uruguai e, de forma introduzida, ocorre no Brasil, Bolívia, Chile, Peru e alguns países europeus (DYER, 2003), tendo sido registrada em todos os reservatórios do rio Iguaçu.

*Bemvenuti (2002) 


\section{Ordem}

\section{CYPRINODONTIFORMES}

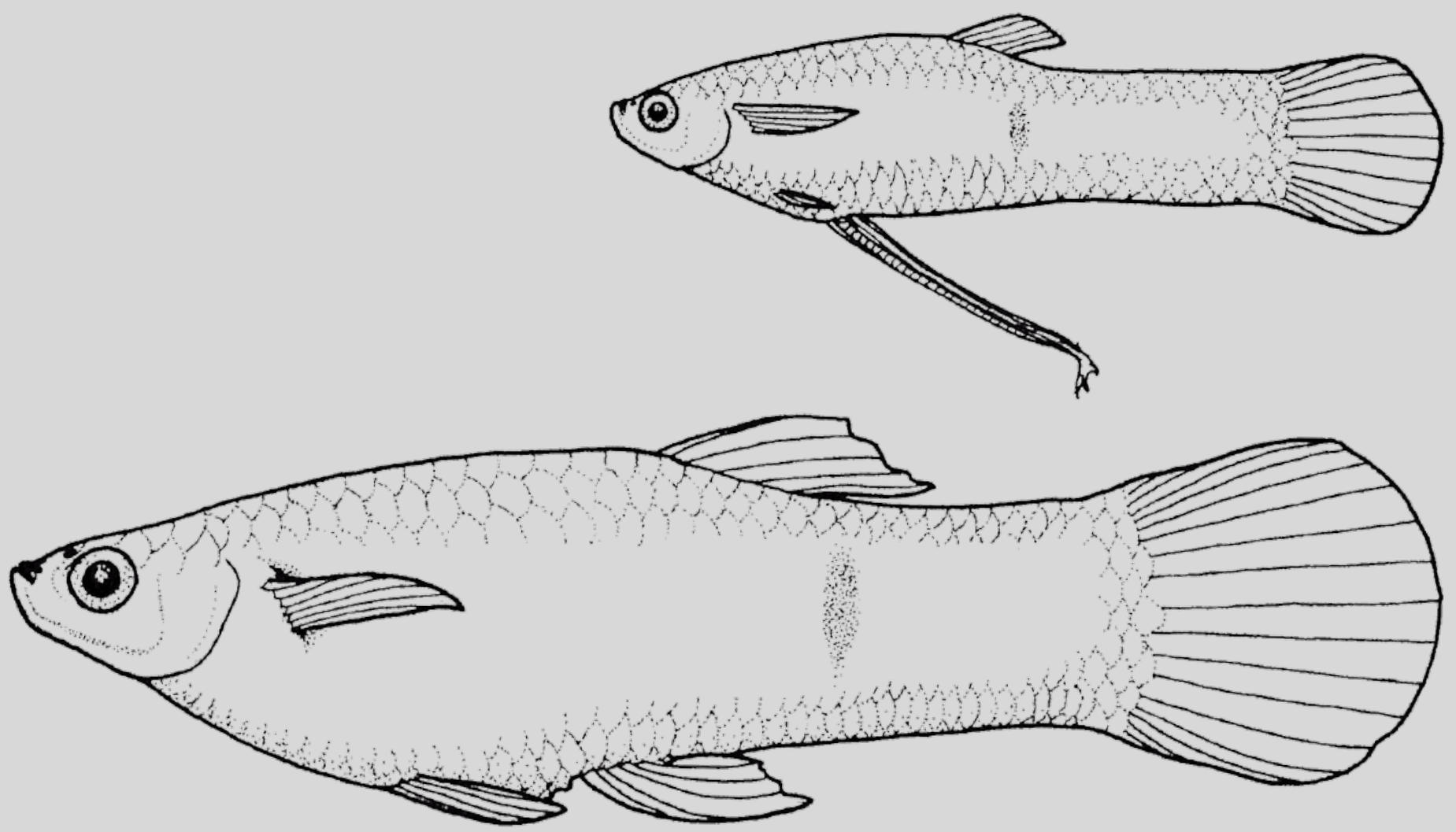

Com representantes de pequeno porte e alguns muito coloridos, esta ordem congrega várias espécies apreciadas por aquaristas. Apresentam a boca protrátil e dimorfismo sexual evidente, com o macho geralmente menor, mas com padrão de colorido bem mais exuberante do que o da fêmea. Na bacia do rio Iguaçu ocorrem duas famílias desta ordem, com espécies menos coloridas e pouco exploradas por aquaristas. 
FAMÍLIAS

Poeciliidae

Anablepidae 


\section{FAMÍLIA}

\section{Poeciliidae}

Apresentam gonopódio (órgão copulador), sendo a maioria das espécies vivípara, com fecundação e desenvolvimento internos, boca terminal e não possuem nadadeira adiposa (LUCINDA, 2003).

\section{- Cnesterodon omorgmatos Lucinda \& Garavello, 2001 Barrigudinho}

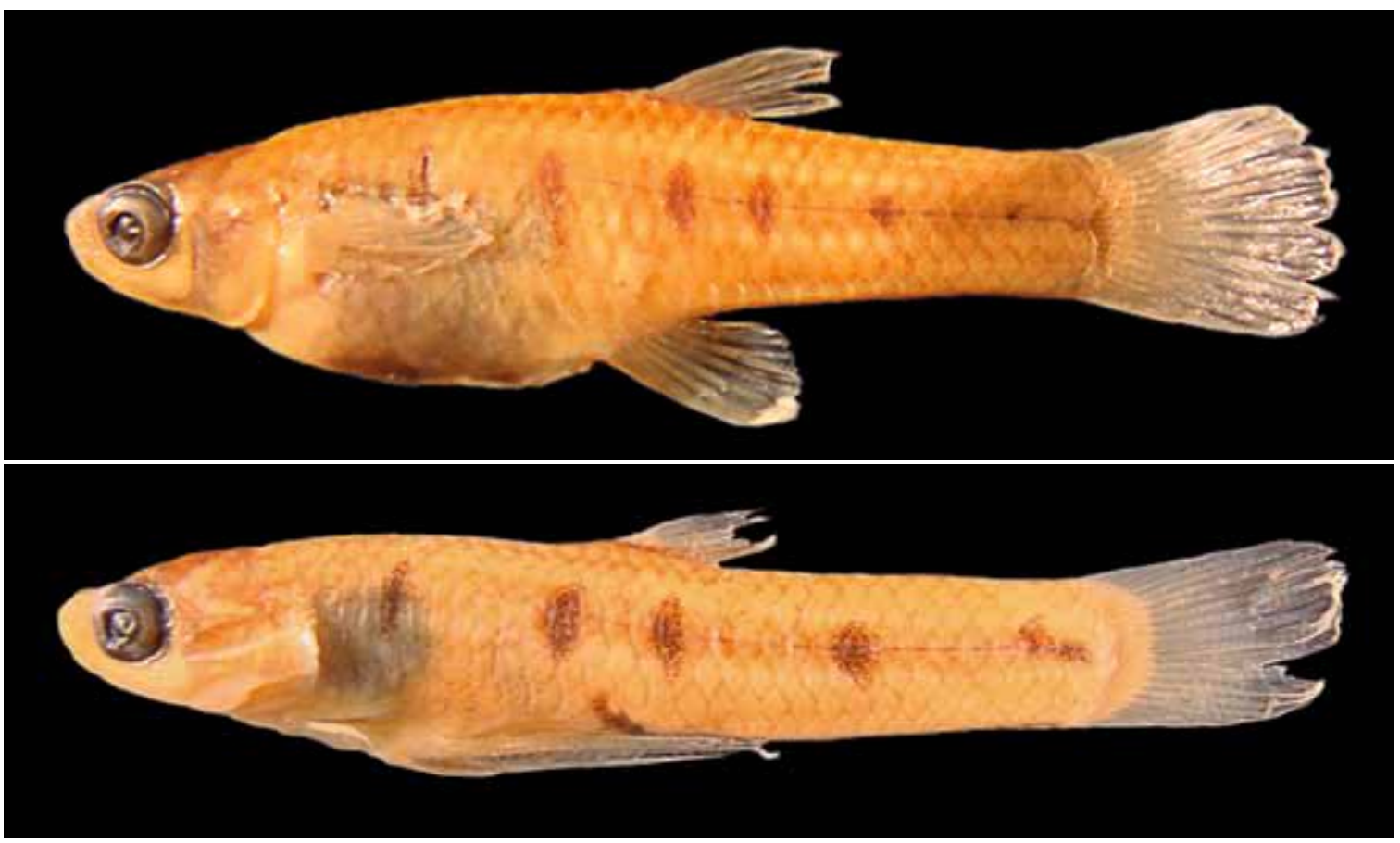

Comprimento padrão 22,4mm (fêmea, acima), 19,4mm (macho, abaixo)

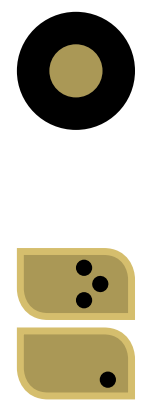

Corpo amarelado, com seis a nove manchas cinzas ou marrom-escuras, verticalmente alongadas e irregulares na lateral do corpo, região superior da cabeça mais escura e nadadeiras hialinas. Espécie de pequeno porte, com corpo alongado, cabeça deprimida na região superior e boca terminal.

Altura do corpo contida 2,9 a 3,4* (machos) e 3,6 a 4,2* (fêmeas), altura do pedúnculo caudal 7,2 a 8,6* (machos) e 7,4 a 8,5* (fêmeas), comprimento da cabeça 4,7 a $5,6^{*}$ (machos) e 4,0 a 4,5* (fêmeas), do pedúnculo caudal 1,9 (machos) e 2,1 (fêmeas), pré-dorsal 1,8 a 1,9* (machos) e 1,6 a 1,7* (fêmeas), do gonopódio 2,6 (machos) e da base da nadadeira anal 10,1 (fêmeas) vezes no CP. Comprimento do focinho contido 4,5 a $5,7^{*}$ (machos) e 3,9 a 6,3* (fêmeas), diâmetro orbital 2,2 a 3,1* (machos) e 2,4 a 2,9* (fêmeas) e distância interorbital 2,9 (machos) e 2,0 (fêmeas) vezes no CC.

Nadadeira dorsal com 8 ou 9* raios, pélvica com 4* raios nos machos e 5* nas fêmeas, anal com 9* raios nos machos e 9 ou 10* nas fêmeas e peitoral com 9 a $11^{*}$ raios ramificados. Possui linha transversal com 9 a $11^{*}$ séries de escamas, linha lateral ausente. 
Esta espécie é considerada rara, ocorrendo apenas na bacia do rio Jordão, a qual apresenta uma taxa de endemismo elevada, mesmo em relação ao próprio rio Iguaçu. Em vista disso, foi considerada como em risco de extinção por Abilhoa e Duboc (2004).
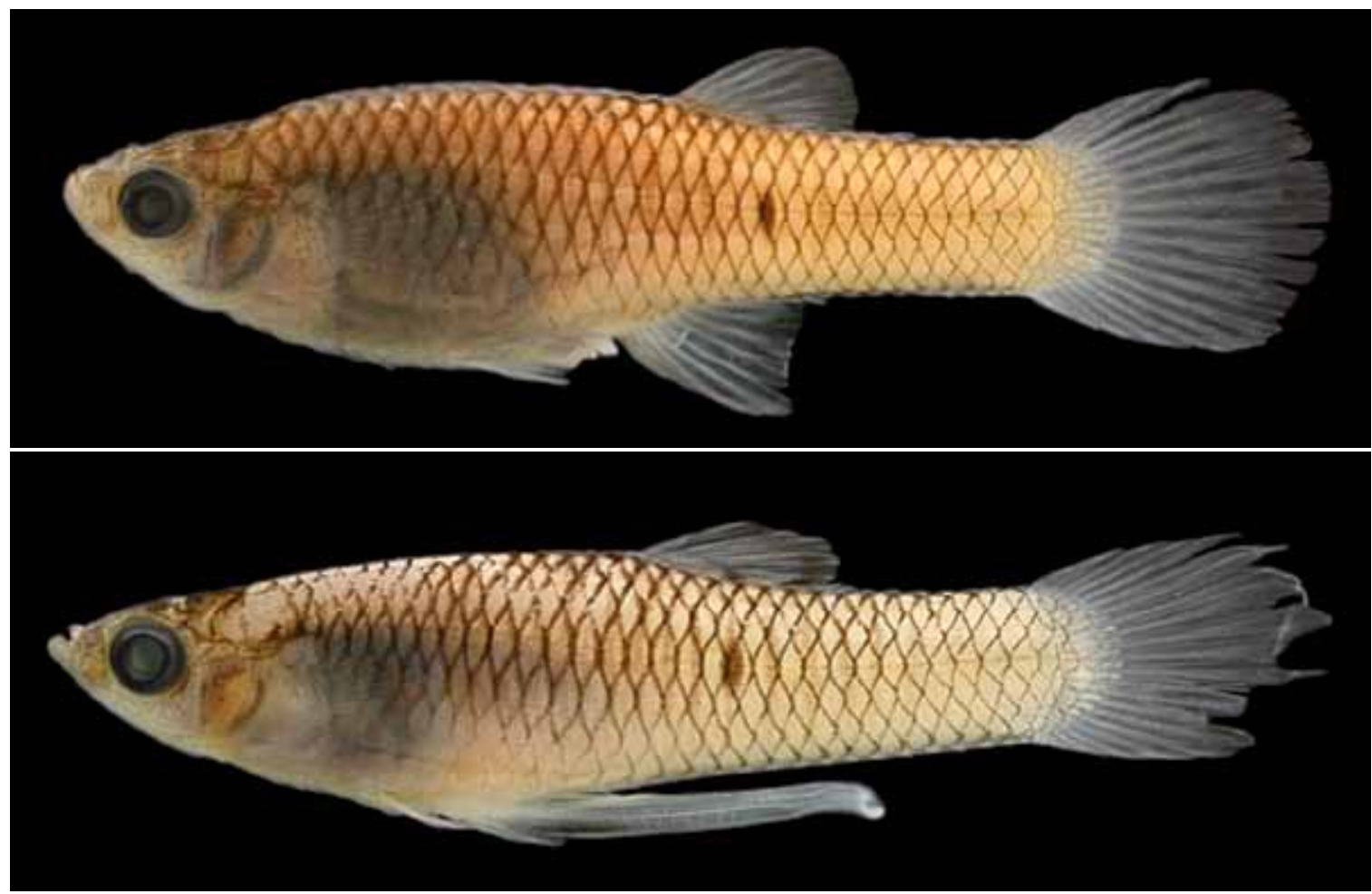

Comprimento padrão 28,0 mm (fêmea, acima), 25,5 mm (macho, abaixo)

Corpo amarelado, com mancha cinza ou marrom-escura alongada verticalmente na lateral do corpo, região superior da cabeça mais escura e nadadeiras hialinas. Espécie de pequeno porte, com corpo alongado, cabeça deprimida na região superior e boca terminal.

Altura do corpo contida 2,5 a 3,6* (machos) e 3,3 a 4,7* (fêmeas), altura do pedúnculo caudal 5,4 a 8,1* (machos) e 5,8 a 8,0* (fêmeas), comprimento da cabeça 4,0 a $5,6^{*}$ (machos) e 3,6 a 5,2* (fêmeas), do pedúnculo caudal 3,4 a 6,4 (machos) e 2,6 a 3,9 (fêmeas), pré-dorsal 1,6 a 1,8* (machos) e 1,5 a 1,7* (fêmeas), do gonopódio 9,4 a 11,1 (machos) e da base da nadadeira anal 8,3 a 14,1* (fêmeas) vezes no CP. Comprimento do focinho contido 3,2 a 7,6* (machos) e 3,0 a 6,5* (fêmeas), diâmetro orbital 1,9 a 2,8* (machos) e 2,1 a 3,3* (fêmeas) e distância interorbital 1,9 a 3,6* (machos) e 1,8 a 2,9* (fêmeas) vezes no CC.

Nadadeira dorsal com 7 a 9* raios, pélvica com $5^{*}$ raios nos machos e 4 ou $5^{*}$ nas fêmeas, anal com 8 a 10* raios nos machos e 10 a 12* nas fêmeas e peitoral com 5 a $8^{*}$ raios ramificados. Possui linha longitudinal com 27 a $30^{*}$ escamas. 
Esta espécie é encontrada em rios, riachos e lagoas pertencentes à bacia dos rios Paraná-Paraguai, incluindo o rio Iguaçu, e nas bacias costeiras do rio Itaboapana (ES) ao rio Araranguá (SC) (LUCINDA, 2008).

\section{FAMÍLIA}

\section{Anablepidae}

Composta por três gêneros, essa família caracteriza-se por apresentar lateralidade na papila urogenital ou gonopódio dos machos, ou seja, estes órgãos apresentam sua extremidade voltada sempre para o mesmo lado do corpo, podendo ocorrer de forma destra ou sinistra. Este caráter pode ser utilizado, inclusive, para diferenciar espécies. Espécies do gênero Jenynsia, único capturado no baixo rio Iguaçu, são caracterizadas por apresentar fertilização interna, viviparidade e a forma do corpo semelhante à dos Cyprinodontiformes (GHEDOTTI, 2003).

\section{Chave para espécies de Jenynsia}

1. Nadadeira anal com 10 raios; faixa marrom-escura longitudinal geralmente descontínua na porção anterior à nadadeira dorsal J. diphyes

1'. Nadadeira anal com 9 raios; faixa marrom-escura longitudinal geralmente contínua na porção anterior à nadadeira dorsal ......... J. eigenmanni 
- Jenynsia diphyes Lucinda, Ghedotti \& Graça, 2006

Canivete, piaba
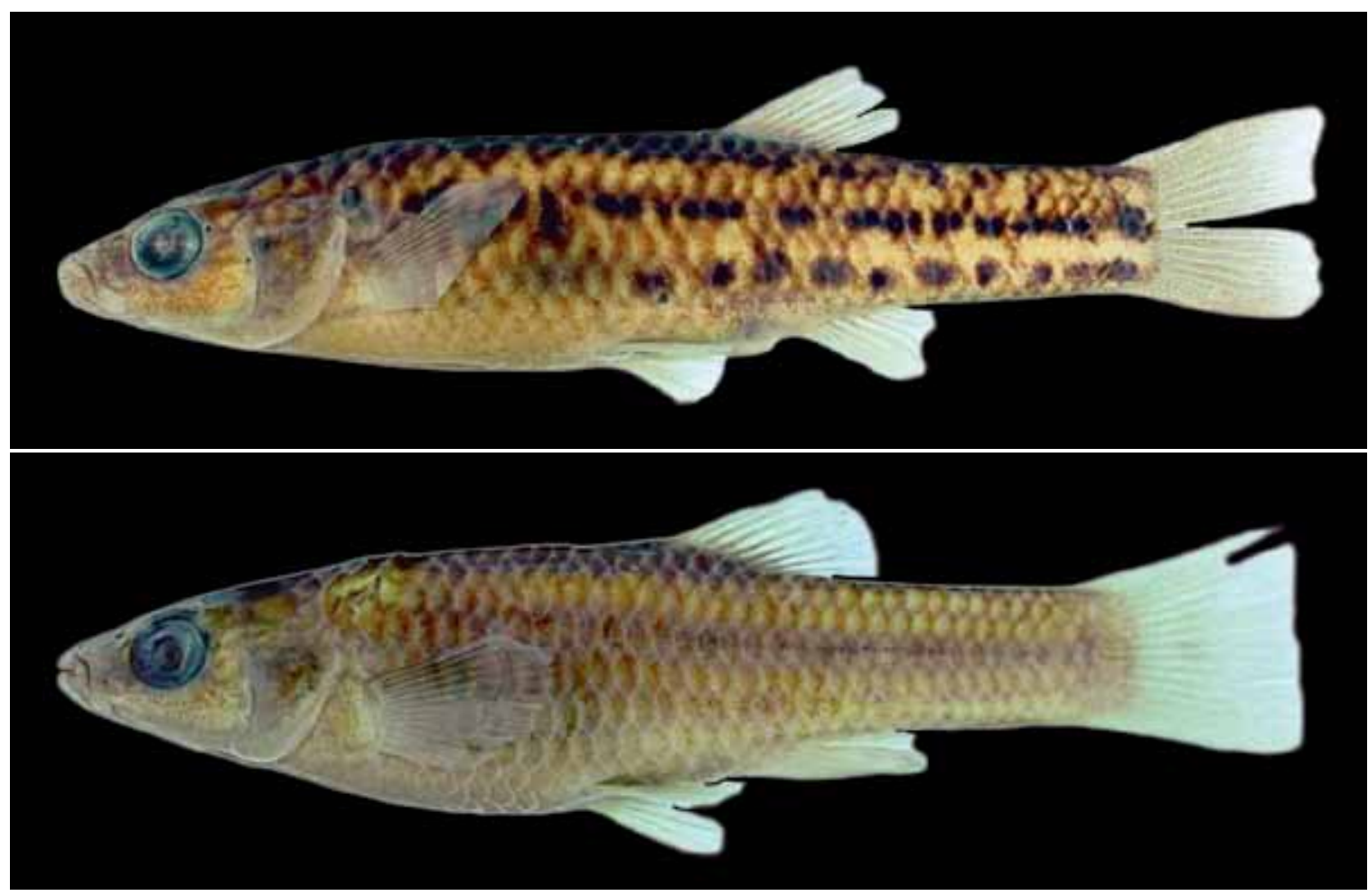

Comprimento padrão 53,2 mm (fêmea, acima), 45,7 mm (macho, abaixo)

Corpo marrom, claro na região do ventre, com uma faixa preta irregular na lateral do corpo, formando manchas horizontalmente alongadas consecutivas. Espécie de pequeno porte, corpo alongado, cabeça curta, afilada, achatada na região superior e boca terminal.

Altura do corpo contida 4,2 a 5,6* (machos) e 4,5 a 5,8* (fêmeas), do pedúnculo caudal 7,4 a $9,6^{*}$ (machos) e 8,0 a 9,6* (fêmeas) no CP, comprimento da cabeça contido 3,6 a 4,2* (machos) e 3,7 a 4,1* (fêmeas), do pedúnculo caudal 3,3 a 4,2 (machos) e 3,4 a 4,3* (fêmeas), pré-dorsal 1,6 a 1,8* (machos e fêmeas), do gonopódio 6,1 a 9,7 (machos) e da base da anal 9,4 a 11,4* (fêmeas) vezes no CP. Comprimento do focinho contido 2,9 a 4,0* (machos) e 3,1 a 3,8* (fêmeas), diâmetro orbital 2,6 a 3,4* (machos) e 2,9 a 3,5* (fêmeas) e distância interorbital 2,7 a 3,6* (machos) e 2,5 a 3,2* (fêmeas) vezes no CC.

Nadadeira dorsal com 9 a $11^{*}$ raios, pélvica com 6 ou $7^{\star}$, anal com $10^{\star}$ e peitoral com 15 a $18^{\star}$ raios. Linha lateral completa com 33 a $36^{\star}$ escamas, linha transversal com 8 séries de escamas.

Espécie encontrada nos córregos Passo do Aterrado e rio das Torres, ambos afluentes do rio Jordão (LUCINDA; GHEDOTTI; GRAÇA, 2006), um afluente do baixo rio Iguaçu que apresenta elevada taxa de endemismo, mesmo em relação ao próprio rio Iguaçu.

\footnotetext{
*Lucinda, Ghedotti e Graça (2006)
} 
- Jenynsia eigenmanni (Haseman, 1911)

Canivete, piaba

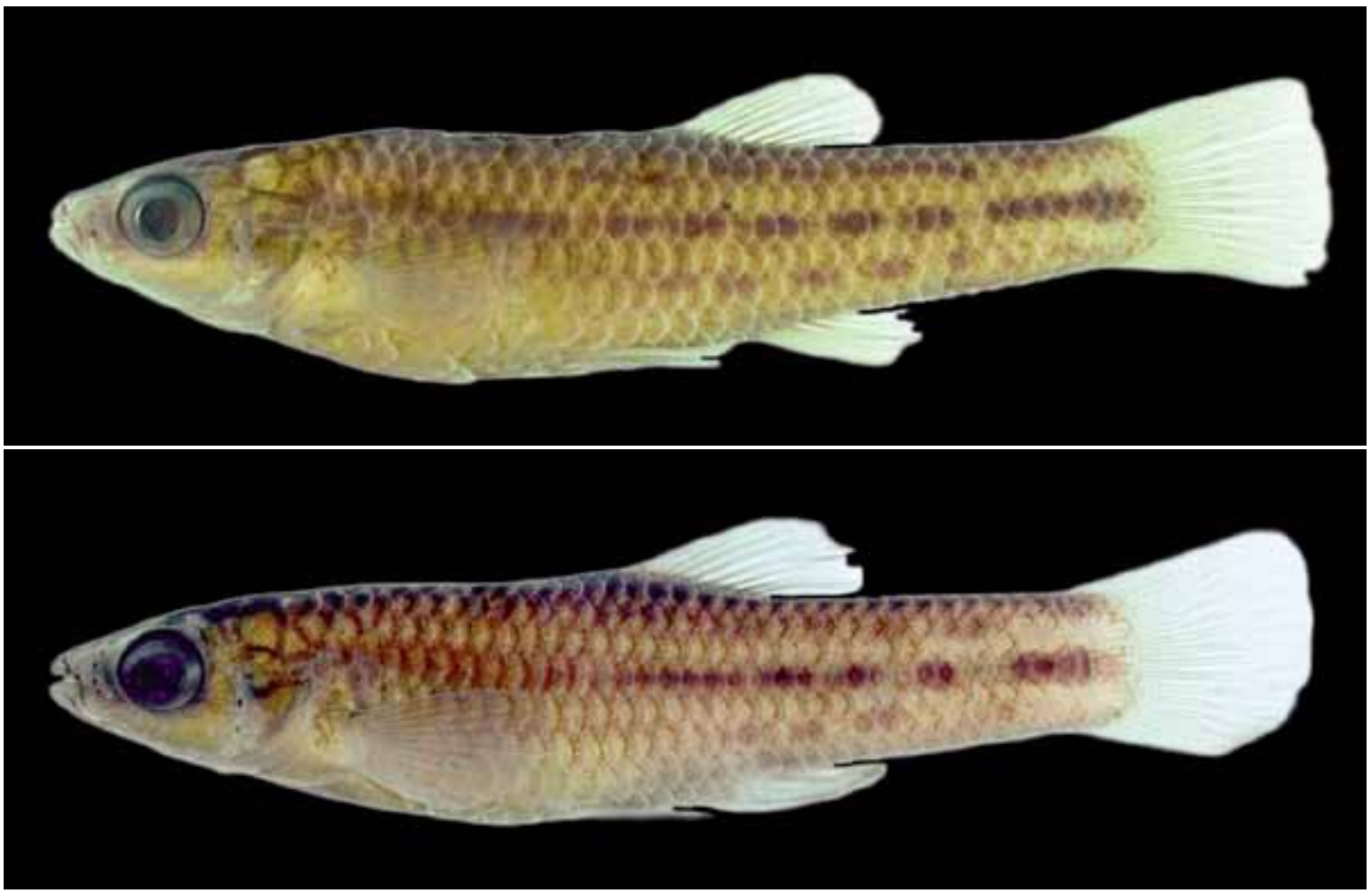

Comprimento padrão 37,9 mm (fêmea, acima), 36,8 mm (macho, abaixo)

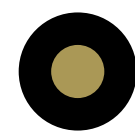

Corpo marrom, claro na região do ventre, com uma faixa castanho-escura quase regular na lateral do corpo. Escamas com pigmentos escuros próximos à extremidade, o que confere a seus exemplares um padrão reticulado. Espécie de pequeno porte, corpo alongado, cabeça achatada na região superior, curta, afilada e boca terminal.

Altura do corpo contida 4,2 a 5,7* (machos) e 4,4 a 5,1* (fêmeas), e do pedúnculo caudal 6,9 a $8,5^{*}$ (machos) e 7,5 a 9,6* (fêmeas) vezes no CP, comprimento da cabeça contido 3,4 a $4,1^{*}$ (machos) e 3,6 a 4,1* (fêmeas), do pedúnculo caudal 3,4 a 3,8* (machos) e 3,3 a 4,0* (fêmeas), pré-dorsal 1,7 a 2,0* (machos) e 1,7 a 1,8* (fêmeas), do gonopódio 6,3 a 7,3 (machos) e da base anal 13,7 a 18,7* (fêmeas) vezes no CP. Comprimento do focinho 3,4 a 4,1* (machos) e 3,2 a 3,8* (fêmeas), diâmetro orbital 2,7 a $3,0^{*}$ (machos) e 2,7 a 3,1* (fêmeas), distância interorbital de 2,0 a 2,3* (machos) e 2,0 a $2,4^{*}$ (fêmeas) vezes no CC.

Nadadeiras dorsal com $9^{*}$ raios, pélvica com $6^{*}$, anal com $9^{\star}$ e peitoral com 13 a $16^{\star}$ raios. Linha lateral completa com 30 a 33* escamas, linha transversal com 8 séries de escamas.

Esta espécie está distribuída no médio e alto rio Iguaçu (LUCINDA; GHEDOTTI; GRAÇA, 2006), além de poucos indivíduos coletados no baixo Iguaçu. 



\section{Ordem}

SYNBRANCHIFORMES

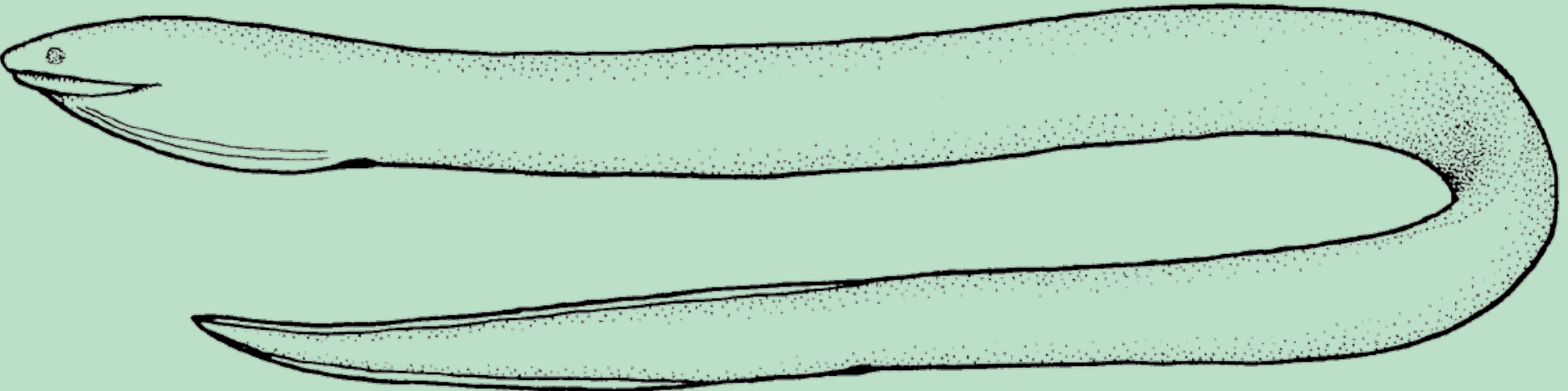

Possuem o corpo serpentiformes e são muito escorregadios quando vivos. Algumas nadadeiras são ausentes, outras vestigiais e as aberturas branquiais unidas em um único orifício situado na porção anteroventral do corpo (NELSON, 2006). Suas espécies podem ocorrer em quase todos os continentes, principalmente na água doce, podendo ocasionalmente ser observadas em ambientes marinhos. No Brasil apenas uma família desta ordem possui representantes. 


\section{FAMIÍLIA}

Synbranchidae 


\section{FAMÍLIA}

\section{Synbranchidae}

Seus exemplares caracterizam-se por apresentar o corpo desprovido de escamas, sem nadadeiras peitorais e pélvicas, nadadeiras dorsal e anal rudimentares ou atrofiadas, olhos pequenos e uma abertura branquial na região ventral, próxima à cabeça (KULLANDER, 2003b). Na bacia do rio Iguaçu ocorre apenas uma espécie desta família, presente em quase todas as bacias da América do Sul.

\section{- Synbranchus marmoratus Bloch, 1795 Mussum}

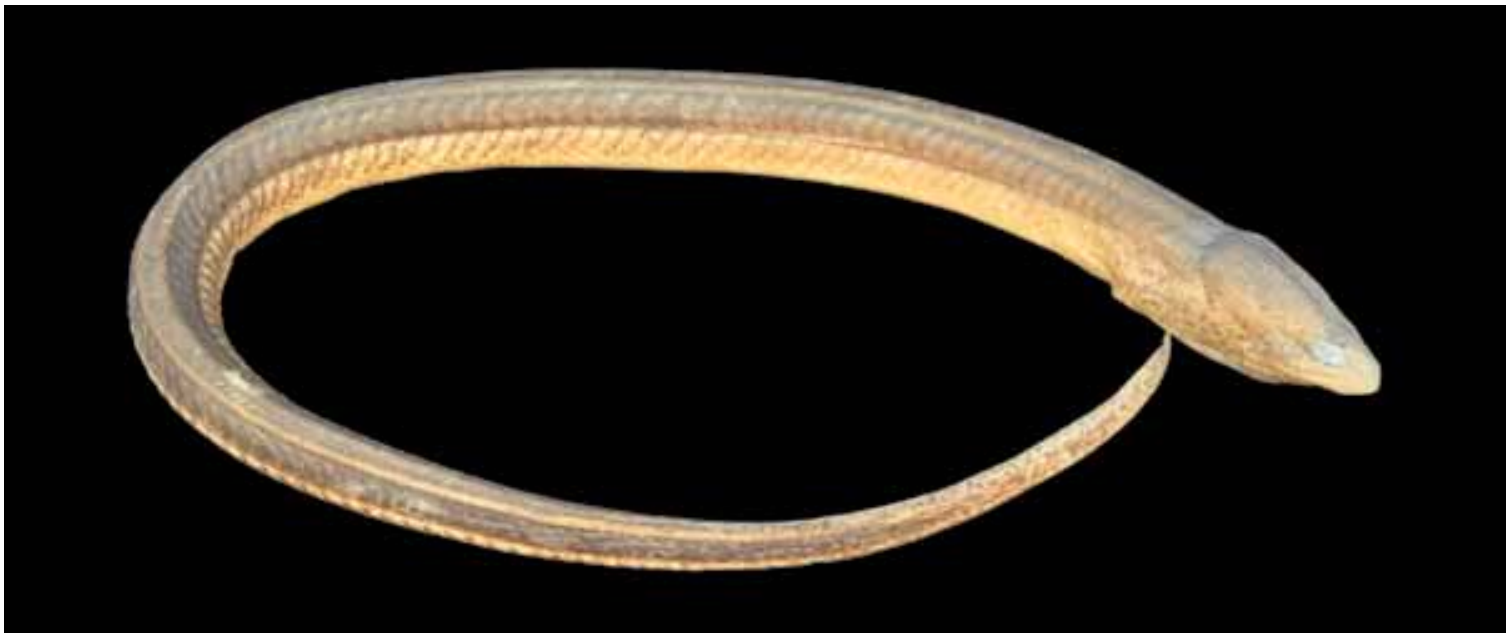

Comprimento padrão 273,2 mm

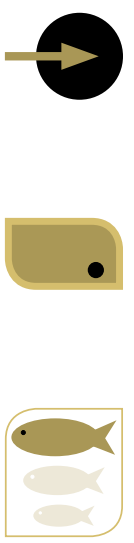

Corpo cinza-escuro, amarelado no ventre, com várias pintas ou manchas pretas por todo o corpo, às vezes pouco visíveis ou confundidas com o colorido de fundo. Corpo muito alongado, serpentiforme, subcilíndrico e com boca ampla e terminal.

Altura do corpo contida 28,0 a 32,0* e comprimento da cabeça 9,0 a 9,3* vezes no CP. Comprimento do focinho contido 3,3 a 4,3*, diâmetro orbital 5,6 a 9,1 e distância interorbital 3,7 a 4,2* vezes no CC.

Possui inúmeros dentes no pré-maxilar e no dentário.

Essa espécie vive em lagoas, rios e riachos, possui capacidade de respirar o ar atmosférico quando necessário, podendo sobreviver por determinado período de tempo em lagoas temporárias no período de seca (BRITSKI; SILIMON; LOPES, 2007). Amplamente distribuída em todo o Brasil (AMORIM; MENEZES, 2007), não parece ser nativa do rio Iguaçu. É utilizada como isca-viva por pescadores profissionais e amadores em diferentes bacias e sua ocorrência esporádica no rio Iguaçu pode provavelmente ser atribuída a esta prática. 



\section{Ordem}

\section{PERCIFORMES}

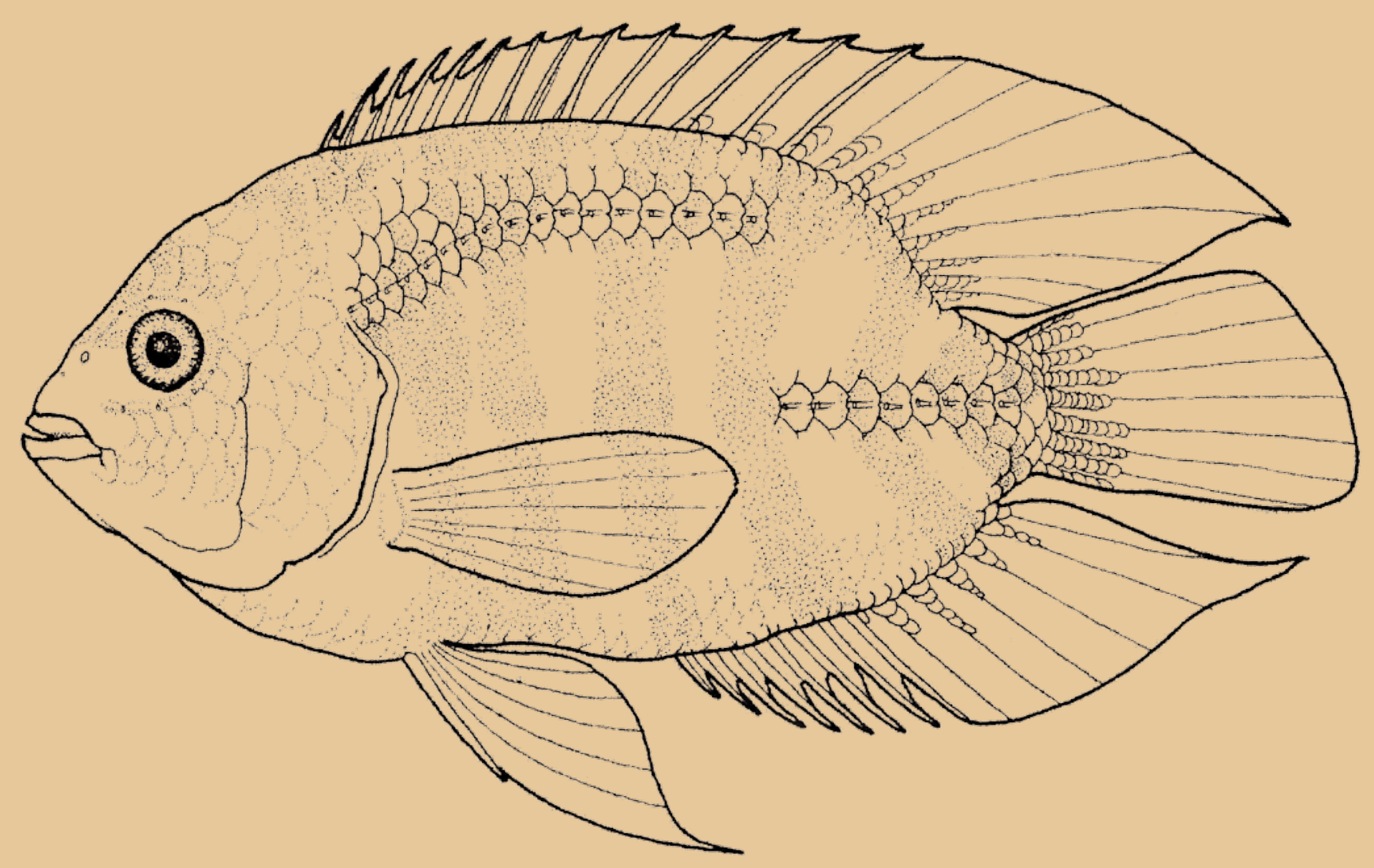

Maior ordem entre os vertebrados e mais diversificada entre os peixes, seus representantes são dominantes nos ambientes marinhos e em muitos de água doce (NELSON, 2006). Apresentam o corpo revestido por escamas e as nadadeiras pélvicas em posição torácica, ou seja, inseridas na metade anterior do tronco, sendo que as peitorais são situadas mais acima quando comparadas com os Characiformes. 
FAMÍLIAS

Centrarchidae

cichlidae 


\section{FAMÍLIA}

\section{Centrarchidae}

Nativos exclusivamente da América do Norte, membros dessa família apresentam cores brilhantes, que se intensificam durante o período reprodutivo. Estas cores estão associadas à voracidade de algumas espécies, o que as torna muito apreciadas na pesca esportiva, atuando como facilitador na sua dispersão para várias partes do mundo. Pelas características territorialistas e de voracidades, a introdução de espécies dessa família deve ser sempre desencorajada. Suas espécies caracterizam-se por possuir linha lateral completa, raramente incompleta, mas não interrompida, e geralmente sigmoidal, o que as diferencia da família Cichlidae (ETNIER; STARNES, 1993).

- Micropterus salmoides (Lacépède, 1802)

Black-bass

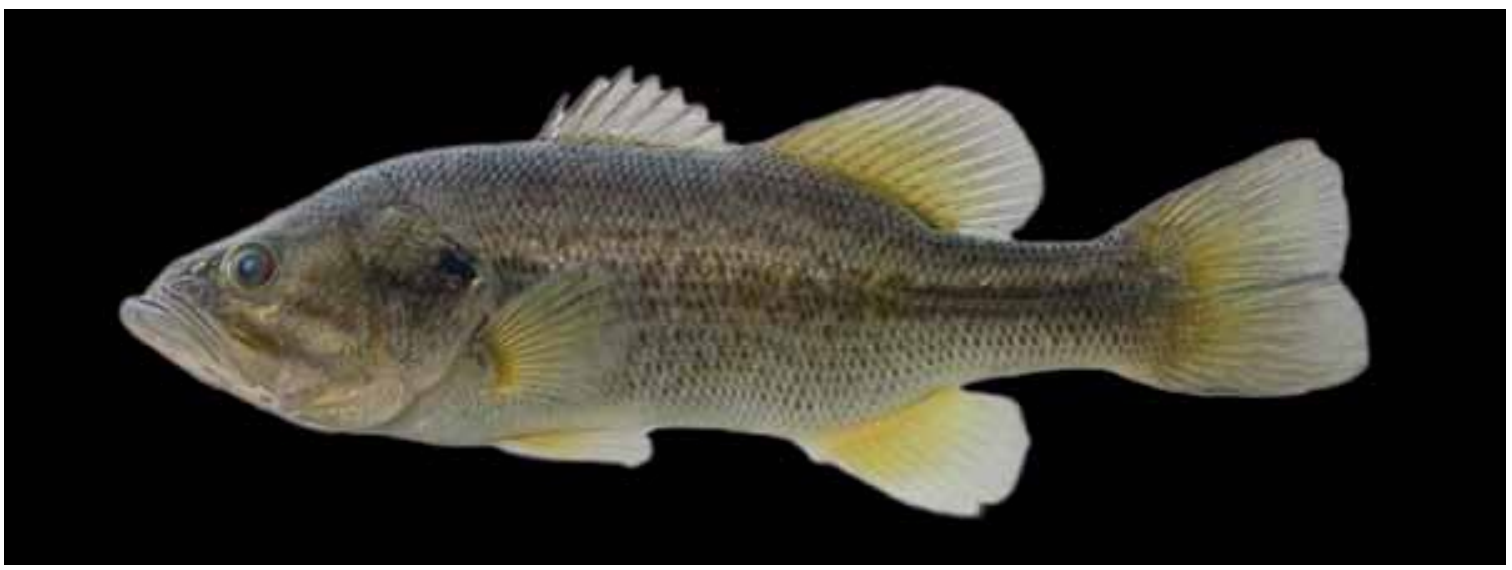

Comprimento padrão 193,6 mm

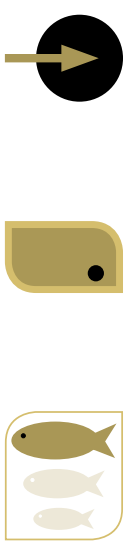

Corpo castanho ou cinza-escuro, mais escuro dorsalmente, clareando em direção à região ventral, apresenta uma mancha preta na região do opérculo, seguida de uma faixa castanha ou cinza-escura pouco conspícua até a base da nadadeira caudal. Boca ampla, com maxilar estendendo-se para trás, podendo ultrapassar a órbita. Corpo alongado, boca superior, com mandíbula prognata, nadadeiras hialinas, com membranas das bases dos raios amareladas quando em vida.

Altura do corpo contida 3,1 a 3,3, do pedúnculo caudal 6,5 a 7,1, comprimento da cabeça 2,9 a 3,1 e do pedúnculo caudal 4,8 a 6,6 vezes no CP. Comprimento do focinho contido 3,6 a 3,8, diâmetro orbital 5,6 a 6,3 e distância interorbital 3,6 a 3,9 vezes no CC.

Nadadeira dorsal com $\mathrm{X}+13$ raios, peitoral com 14, pélvica com 6 e anal com III+12 raios. Linha lateral completa com 62 a 65 escamas perfuradas, linha transversal superior com 8 e inferior com 18 séries de escamas.

Adultos dessa espécie alimentam-se predominantemente de peixes. Durante o período reprodutivo, seus machos constroem ninhos para onde atraem as fêmeas, que após o acasalamento depositam seus ovos, que se tornam adesivos após a fertilização (ETNIER; STARNES, 1993). Nativa das regiões central e oeste dos Estados Unidos, foi introduzida em diversos ambientes do mundo devido à sua atratividade para a pesca esportiva (ETNIERS; STARNES, 1993). 


\section{FAMÍLIA}

\section{Cichlidae}

Membros dessa família são muito apreciados por aquariofilistas e pescadores esportivos. Apresentam dimorfismo sexual com variações no padrão de colorido que se intensificam no período reprodutivo. A preferência por ambientes lênticos, juntamente com o cuidado parental, proporcionam amplo sucesso reprodutivo em reservatórios. Essa família caracteriza-se por reunir espécies com linha lateral dividida em dois ramos (superior e inferior), boca protrátil, pré-maxilar móvel e dentes cônicos (KULLANDER, 2003a). Os ciclídeos apresentam hábito diurno (BRITSKI; SILIMON; LOPES, 2007), sendo algumas de suas espécies consideradas predadores visuais.

\section{Chave para espécies de Australoheros}

1. Nadadeira anal com 7 espinhos A. angiru

1'. Nadadeira anal com 6 espinhos A. kaaygua

- Australoheros angiru Říčan, Piálek, Almirón \& Casciotta, 2011 Acará, cará

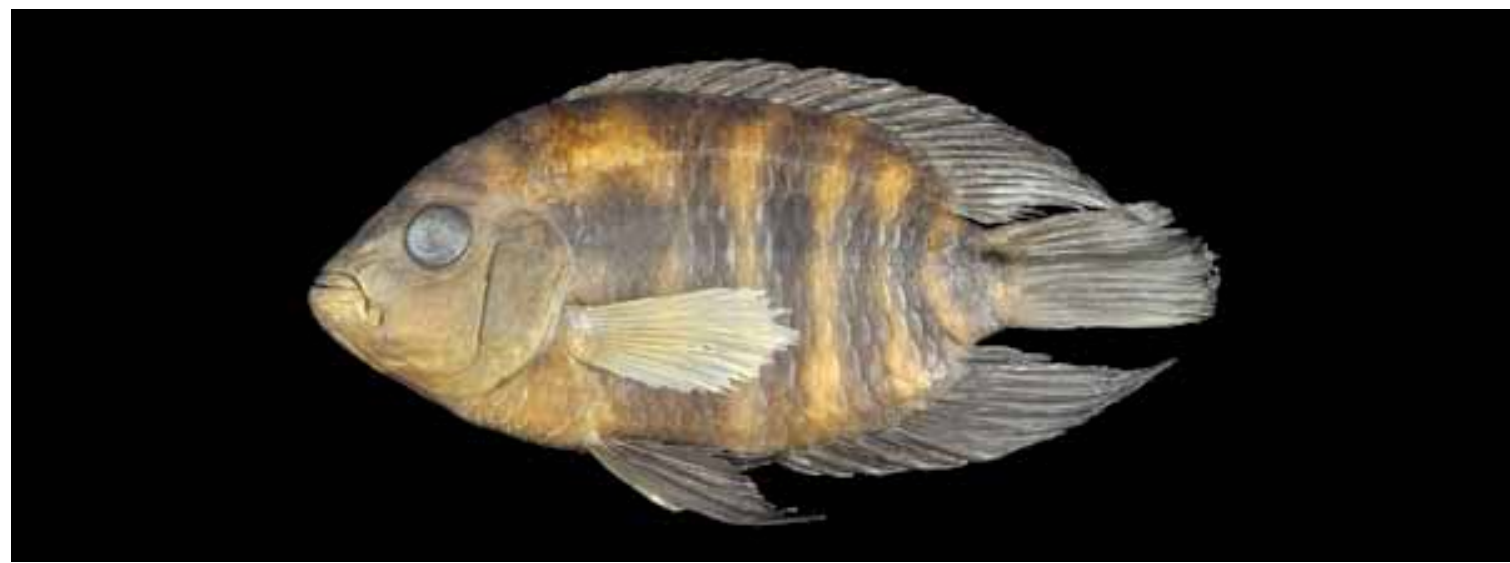

Comprimento padrão 193,6 mm

Corpo castanho-claro, mais escuro dorsalmente e mais claro na região ventral. Lateral do corpo com seis a sete faixas cinza-escuras verticais. Mancha preta ovalada ou subcircular sobre a $4^{\circ}$ faixa vertical da lateral do corpo. Corpo alto, boca terminal ou levemente prognata, nadadeiras claras com pigmentos pretos dispersos, dorsal e anal com escamas entre e sobre a base dos raios. Mancha preta arredondada na região superior da base da nadadeira caudal.

Corpo alto, sua altura contida 1,9 a 2,2, do pedúnculo caudal 5,0 a 6,2, comprimento da cabeça 2,6 a 2,9, pré-dorsal 2,2 a 2,5 e do pedúnculo caudal 16,2 a 18,1 vezes no CP. Comprimento do focinho contido 2,6 a 3,1, diâmetro orbital 3,2 a 4,0 e distância interorbital 2,4 a 2,6 vezes no CC.

Nadadeira dorsal com XV ou XVI+9 a 11 raios, peitoral com 11 ou 12, pélvica com I+ 5 e anal com VII+8 ou 9 raios. Linha lateral interrompida, sendo o ramo superior com 
16 a 18 escamas perfuradas e o inferior com 8 a 10, linha transversal superior com 4 e inferior com 4 ou 5 séries de escamas.

Sua distribuição geográfica abrange o rio Iguaçu e o alto rio Uruguai (ŘÍČAN; PIÁLEK; ALMIRÓN; CASCIOTTA, 2011).

\section{- Australoheros kaaygua Casciotta, Almirón \& Gomes, 2006 Acará, cará}

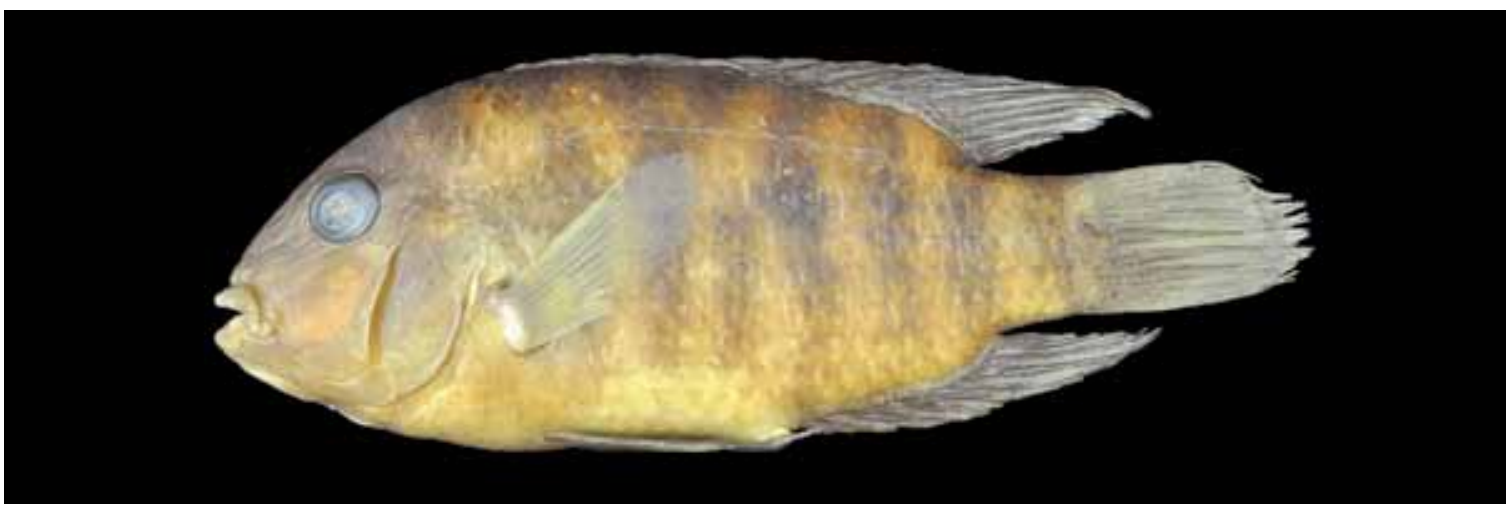

Comprimento padrão 117,8 mm

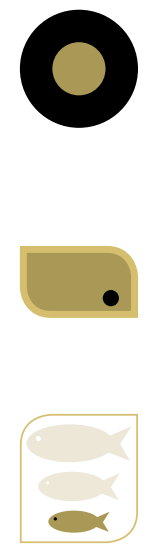

Corpo castanho-claro, mais escuro dorsalmente e mais claro na região ventral. Lateral do corpo com seis a sete faixas cinza-escuras verticais. Mancha preta ovalada ou subcircular sobre a $4^{\circ}$ faixa vertical da lateral do corpo. Corpo alto, boca terminal, nadadeiras claras com pigmentos pretos dispersos, dorsal e anal com escamas entre e sobre a base dos raios. Mancha preta arredondada na região superior da base da nadadeira caudal.

Corpo baixo, sua altura contida 2,1 a 2,3, do pedúnculo caudal 5,6 a 6,0, comprimento da cabeça 2,6 a 2,9, pré-dorsal 2,3 a 2,4 e do pedúnculo caudal 10,0 a 17,2 vezes no CP. Comprimento do focinho contido 2,1 a 2,9, diâmetro orbital 2,9 a 4,0 e distância interorbital 2,3 a 3,4 vezes no CC.

Nadadeira dorsal com XV ou XVI+9 a 11 raios, peitoral com 13 ou 14, pélvica com I+5 e anal com VI+8 ou 9 raios. Linha lateral interrompida, sendo o ramo superior com 17 ou 18 escamas perfuradas e o inferior com 8 a 12, linha transversal superior com 4 e inferior com 4 ou 5 séries de escamas.

Sua distribuição geográfica é restrita à bacia do rio Iguaçu. 
- Cichla kelberi Kullander \& Ferreira, 2006

Tucunaré

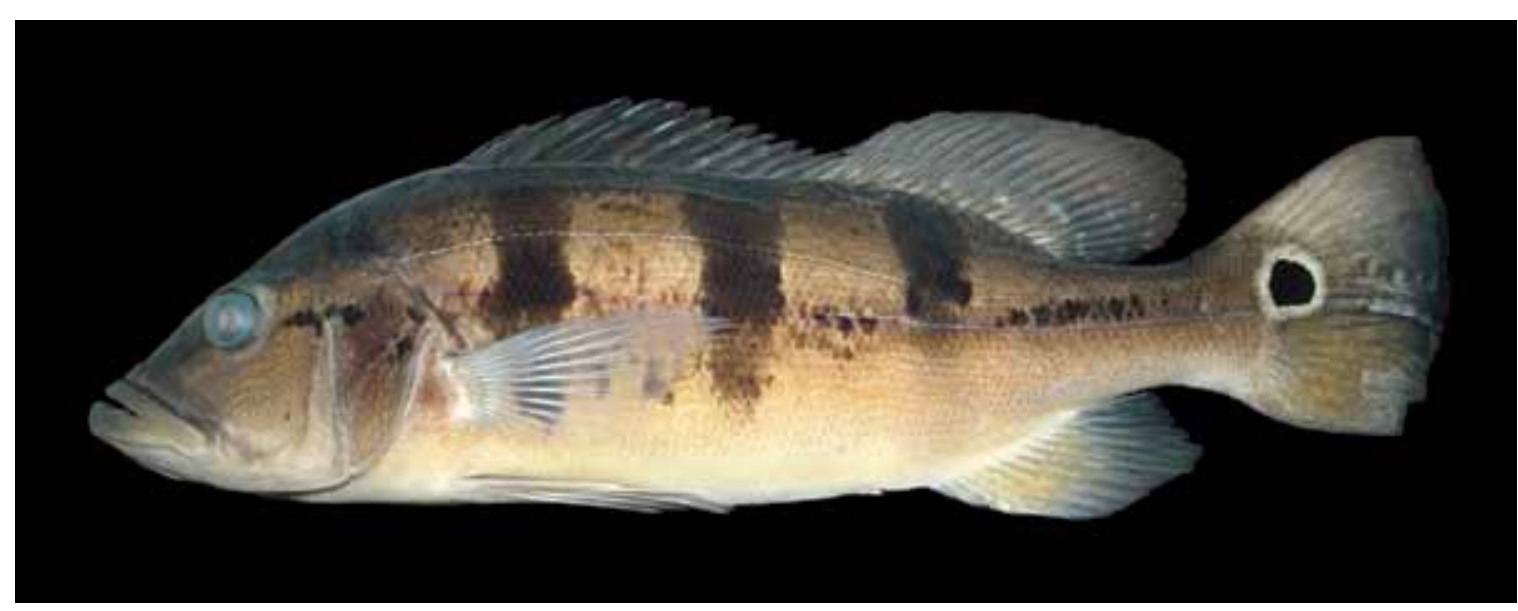

Comprimento padrão 247,5 mm

Corpo castanho-oliva, mais claro na região ventral, com três a quatro faixas verticais marrom-escuras na lateral do corpo, mancha ocelar preta circundada por uma estreita região esbranquiçada ou amarelada, localizada na base da nadadeira caudal. Outras manchas pretas irregulares podem aparecer na lateral do corpo. Nadadeira dorsal e raios medianos da caudal escurecidos, com pintas brancas ou amareladas, corpo alongado e boca ampla e terminal.

Altura do corpo contida 2,3 a $3,7^{*}$, da cabeça 3,0 a $3,2^{*}$, do pedúnculo caudal 5,0 a $6,7^{*}$, comprimento do pedúnculo caudal 8,2 a $9,3^{*}$ e da cabeça 2,8 a $3,2^{*}$ vezes no CP. Comprimento do focinho contido 2,5 a $3^{*}$, diâmetro orbital 4,5 a $6,2^{*}$ e distância interorbital 3,2 a $4,4^{*}$ vezes no CC.

Nadadeira dorsal com XIV a XVI+12 a 17* raios, peitoral com 14 a 16*, pélvica com I+6* e anal com II ou III +9 a $11^{*}$ raios. Linha lateral interrompida, sendo o ramo superior com 70 a $85^{*}$ e o inferior com 52 a $59^{\star}$ escamas, linha transversal superior com 10 a $14^{*}$ e inferior com 17 a $23^{*}$ séries de escamas.

Essa espécie é nativa das bacias dos rios Araguaia e baixo Tocantins, e foi introduzida em represas do Rio Grande do Norte, Minas Gerais, Ceará, Paraíba do Sul, alto rio Paraná e possivelmente no rio São Francisco (BUCKUP; TEIXEIRA, 2007), assim como na bacia do rio Iguaçu. Seus hábitos de vida podem desestabilizar o equilíbrio da ictiofauna se ela se estabelecer na bacia. 
- Cichlasoma paranaense Kullander, 1983

Acará, cará

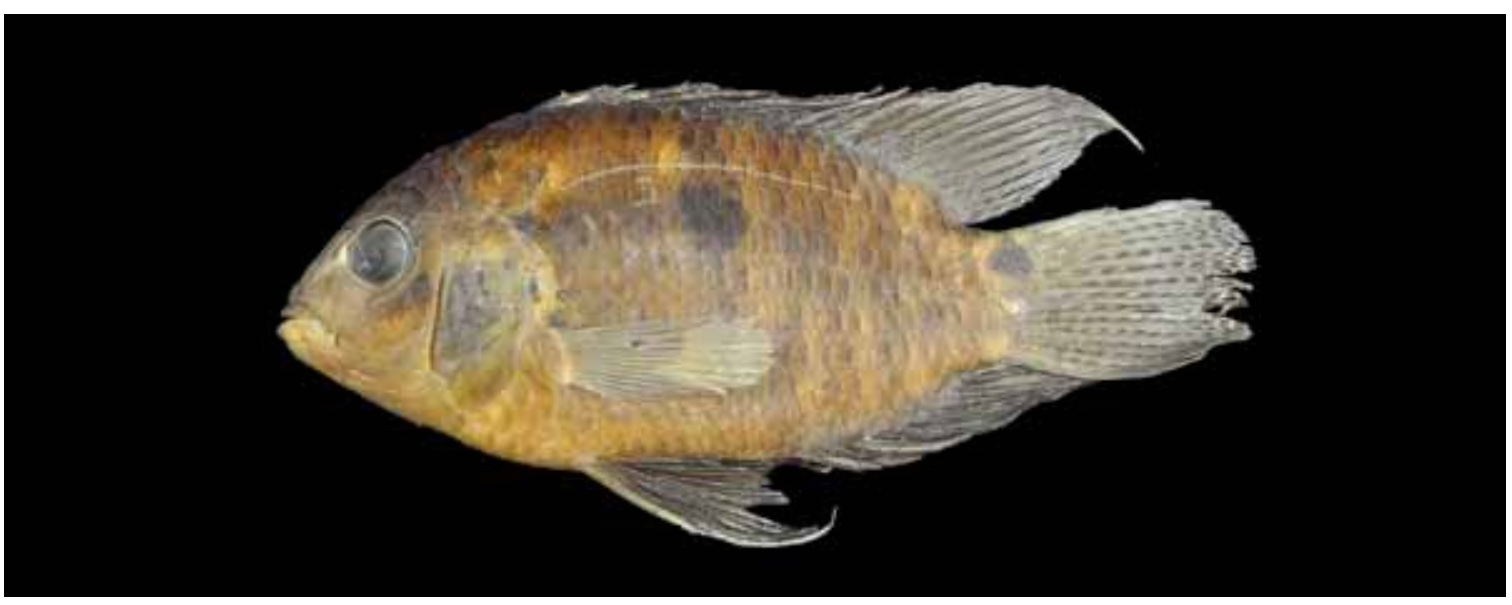

Comprimento padrão $76,2 \mathrm{~mm}$

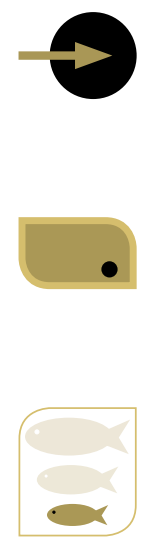

Corpo esverdeado, mais claro na região ventral. Lateral do tronco com faixas cinza-escuras verticais. Mancha preta ovalada ou subcircular abaixo da linha lateral superior. Corpo alto, boca terminal, nadadeiras claras com pigmentos pretos dispersos, dorsal e anal com escamas entre e sobre a região proximal dos raios. Mancha preta arredondada na região superior da base da nadadeira caudal.

Altura do corpo contida 1,7 a $2,5^{*}$, do pedúnculo caudal 4,9 a $6,4^{*}$, comprimento da cabeça 1,3 a $2,4^{*}$, pré-dorsal 2,2 a $2,4^{*}$ e do pedúnculo caudal 10,2 a $16,4^{*}$ vezes no CP. Comprimento do focinho contido 3,0 a 3,6* diâmetro orbital 3,5 a 4,4* e distância interorbital 4,2 a 5,0* vezes no CC.

Nadadeira dorsal com XIII a XV+10 a 15* raios, peitoral com 12 ou 13*, pélvica com I+6* e anal com III +8 a $10^{*}$ raios. Linha lateral interrompida, sendo o ramo superior com 14 a $17^{*}$ escamas perfuradas e o inferior com 5 a $8^{*}$; linha transversal superior com $2 \frac{1}{2}$ a $5^{*}$ e inferior com 5 a $7^{*}$ séries de escamas.

Cichlasoma paranaense ocorre naturalmente na bacia do alto rio Paraná (KULLANDER, 1983). Sua ocorrência na bacia do rio Iguaçu é esporádica, e pode ter sido causada por aquaristas, ou outros meios não identificados.

*Kullander (1983) 


\section{Chave para espécies de Crenicichla}

1. Pintas pretas ausentes no tronco; maxilas isognatas, ou a superior levemente mais longa

1'. Pintas pretas presentes no tronco; maxilas isognatas, ou a inferior prognata

2'. Pintas pretas presentes sobre a cabeça; maxila inferior prognata C. iguassuensis

2'. Pintas pretas ausentes sobre a cabeça; maxilas isognatas, ou a inferior levemente prognata

\section{- Crenicichla iguassuensis Haseman, 1911} Joaninha

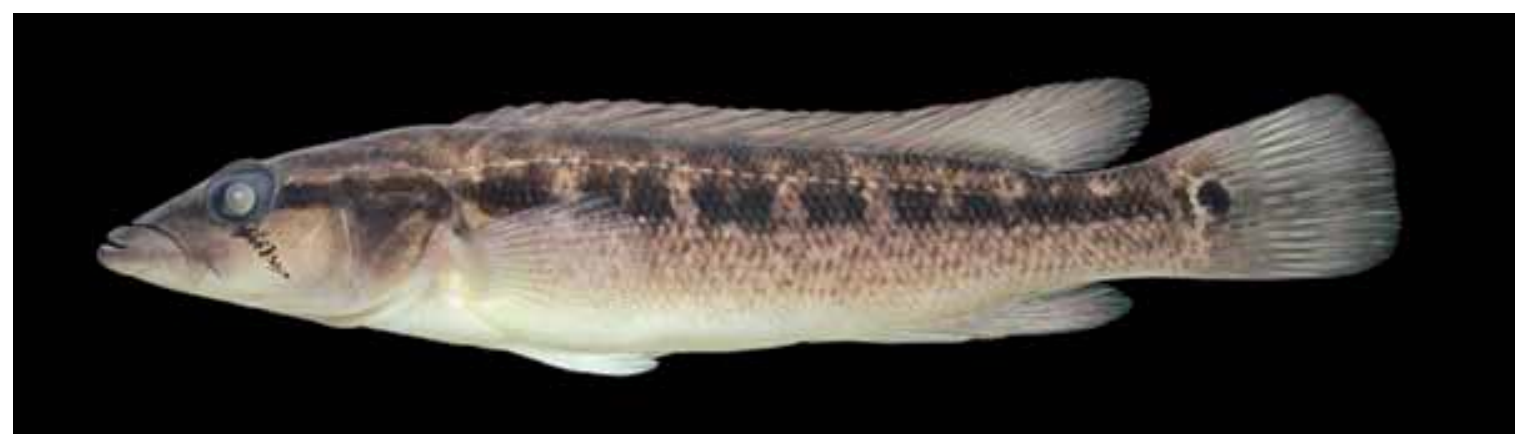

Comprimento padrão 114,0 mm

Corpo marrom-oliva, mais intenso na região dorsal, com pintas castanho-escuras dispersas no flanco e na cabeça, uma faixa preta diagonal originando-se abaixo do olho, mancha ocelar preta, circundada por uma estreita área esbranquiçada ou amarelada na porção superior da base da nadadeira caudal. Nadadeiras peitoral e pélvica amareladas, dorsal, anal e caudal com pigmentos escuros dispersos, às vezes formando pintas. Série horizontal de 5 a 6 manchas pretas, retangulares, mas de limites irregulares nos flancos, situadas abaixo da linha lateral superior, sendo a última delas mais alongada horizontalmente. Corpo e cabeça alongados, boca terminal com mandibula prognata. Alguns exemplares podem apresentar os lábios intumescidos.

Altura do corpo contida 4,2 a 5,7, do pedúnculo caudal 9,0 a 11,1, comprimento da cabeça 2,9 a 3,4 e do pedúnculo caudal 5,9 a 6,7 vezes no CP. Comprimento do focinho contido 2,7 a 4,7, diâmetro orbital 5,0 a 8,6 e distância interorbital 3,0 a 5,8 vezes no CC.

Nadadeira dorsal com XXI a XXIII+11 a 13 raios, pélvica com 6, anal com III+9 ou 10 e peitoral com 16 raios. Linha lateral interrompida, sendo o ramo superior com 24 a 27 escamas perfuradas e o inferior com 10 a 13 escamas, linha transversal superior com 12 ou 13 e inferior com 4 ou 5 séries de escamas.

No reservatório de Segredo, o principal alimento consumido por esta espécie foi peixe, com utilização alternativa de crustáceos (HAHN; FUGI; ALMEIDA; RUSSO; LOUREIRO, 1997). No reservatório de Salto Caxias, a espécie comportou-se essencialmente como micro e macroinvertívora (DELARIVA, 2002). Seu período reprodutivo ocorre de 
outubro a dezembro (UNIVERSIDADE ESTADUAL DE MARINGÁ, 2002), com os indivíduos iniciando a atividade reprodutiva com $\mathrm{CP}=82,0 \mathrm{~mm}$ nos machos e $\mathrm{CP}=70,0 \mathrm{~mm}$ nas fêmeas (UNIVERSIDADE ESTADUAL DO OESTE DO PARANÁ, 2008b, 2009a, 2009b). Sua distribuição geográfica é restrita à bacia hidrográfica do rio Iguaçu (BUCKUP; TEXEIRA, 2007).

\section{- Crenicichla tesay Casciotta \& Almirón, 2008} Joaninha

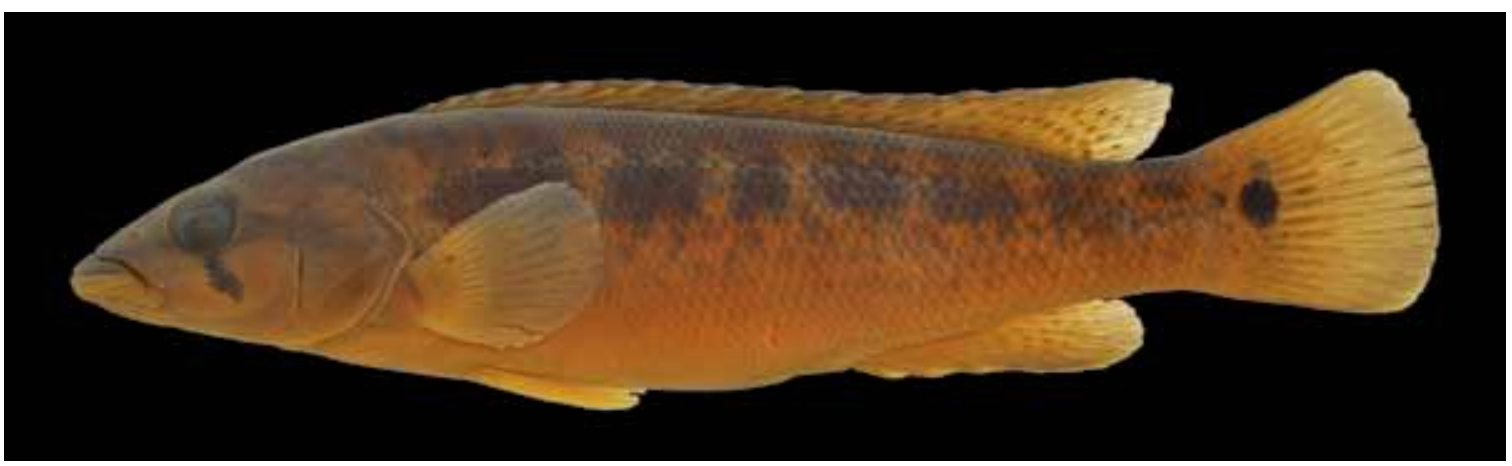

Comprimento padrão 98,0 mm
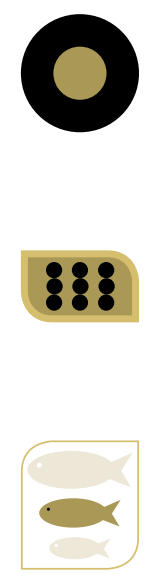

Corpo castanho-claro, mais claro no ventre, com pintas pretas no flanco, mas ausentes na cabeça, uma faixa preta diagonal originando-se abaixo do olho, mancha ocelar preta, circundada por uma estreita área esbranquiçada ou amarelada na porção superior da base da nadadeira caudal. Nadadeiras peitoral e pélvica amareladas, dorsal, anal e caudal com pigmentos escuros dispersos, às vezes formando pintas. Corpo e cabeça alongados, boca terminal com maxilas isognatas ou inferior levemente prognata. Alguns exemplares podem apresentar os lábios intumescidos.

Altura do corpo contida 4,1 a 5,2*, do pedúnculo caudal 8,6 a 10,6*, comprimento da cabeça 2,7 a $3,1^{*}$ e do pedúnculo caudal 5,9 a $6,5^{*}$ vezes no CP. Comprimento do focinho contido 3,0 a 4,3, diâmetro orbital 3,1 a 4,4 e distância interorbital 4,7 a 8,1 vezes no $C$ C.

Nadadeira dorsal com XXI ou XXII+9 a 12* raios, pélvica com 6 raios, anal com III +8 ou 9 raios e peitoral com 17 e $18^{*}$ raios. Linha lateral interrompida, sendo o ramo superior com 22 a 28* escamas perfuradas e o inferior com 7 a $16^{*}$ escamas, linha transversal superior com 12 ou 13 e inferior com 4 ou 5 séries de escamas.

Distribuição geográfica restrita à bacia hidrográfica do rio Iguaçu.

*Casciotta e Almirón (2008) 
- Crenicichla yaha Casciotta, Almirón \& Gómez, 2006 Joaninha

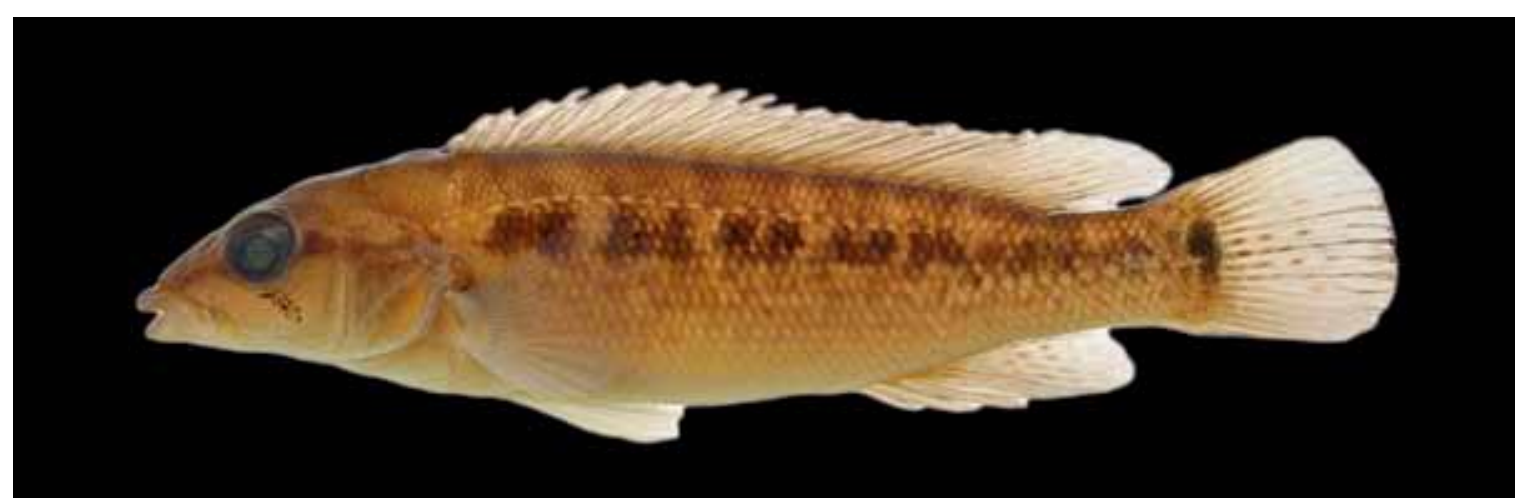

Comprimento padrão 83,2 mm

Corpo castanho-claro, amarelado ou cinza-claro no ventre, com seis a oito manchas castanho-escuras retangulares no flanco, formando uma faixa longitudinal descontínua, eventualmente com pintas castanhas na cabeça, faixa preta diagonal originando-se abaixo do olho, mancha ocelar preta, circundada por uma estreita área esbranquiçada ou amarelada na porção superior da base da nadadeira caudal. $\mathrm{Na}$ dadeiras peitoral e pélvica amareladas, dorsal, anal e caudal com pigmentos escuros dispersos, às vezes formando pintas. Corpo e cabeça alongados, boca terminal com maxilas isognatas ou superior levemente maior.

Altura do corpo contida 3,6 a 4,3* do pedúnculo caudal 8,5 a 9,7*, comprimento da cabeça 3,0 a $3,2^{*}$ e do pedúnculo caudal 5,6 a 7,2* vezes no CP. Comprimento do focinho contido 2,8 a 3,4, diâmetro orbital 3,2 a 4,1 e distância interorbital 4,0 a 5,4 vezes no CC. Alguns exemplares podem apresentar os lábios intumescidos.

Nadadeira dorsal com XX a XXII+10 ou 11* raios, pélvica com 6, anal com III+7 ou $8^{*}$ e peitoral com 15 ou $16^{*}$ raios. Linha lateral interrompida, sendo o ramo superior com 17 a $27^{*}$ escamas perfuradas e o inferior com 9 a $14^{*}$ escamas, linha transversal superior com 11 a 13 e inferior com 4 séries de escamas.

Distribuição geográfica restrita à bacia hidrográfica do rio Iguaçu e arroio Urugua-í, bacia do baixo rio Paraná (CASCIOTTA; ALMIRÓN; GÓMEZ, 2006b).

*Casciotta, Almirón e Gómez (2006b) 
- Geophagus brasiliensis (Quoy \& Gaimard, 1824)

Acará, cará

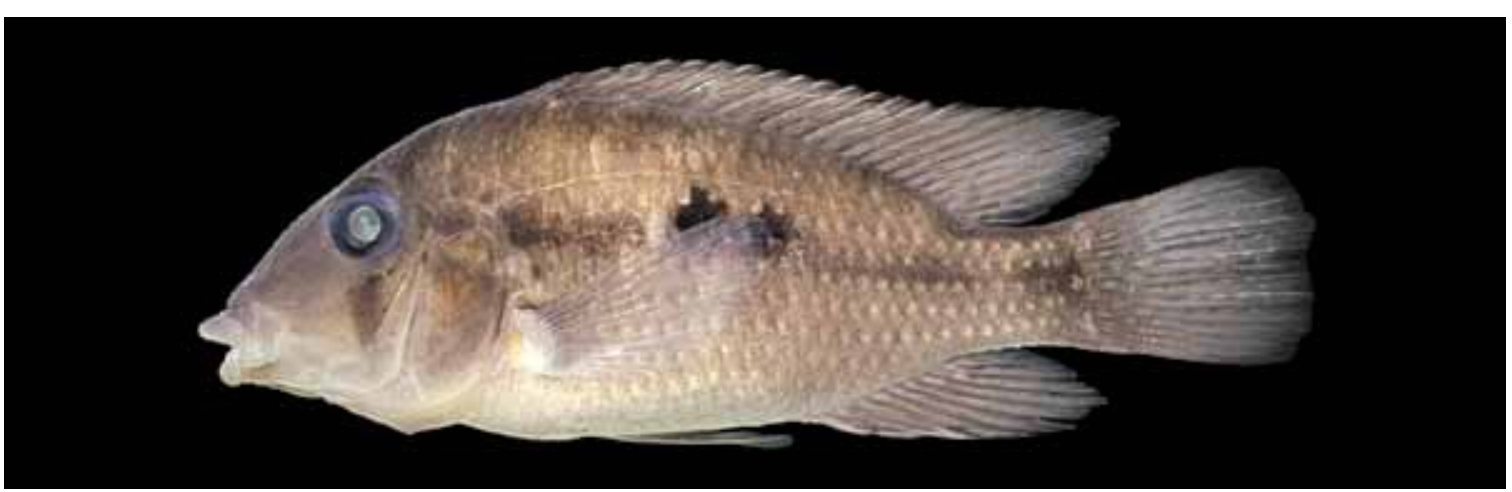

Comprimento padrão $92,0 \mathrm{~mm}$

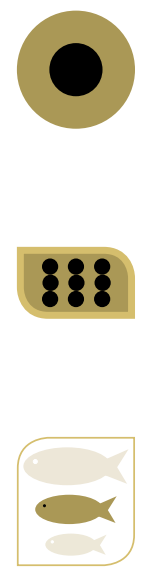

Corpo castanho, mais escuro na região dorsal, às vezes com faixas longitudinais castanho-escuras inconspícuas ao longo do flanco, mancha preta arredondada no flanco abaixo da linha lateral superior. Nadadeiras dorsal, pélvica e anal castanhas, com pequenas manchas esbranquiaçadas ou amareladas e nadadeira peitoral hialina. Faixa transversal marrom-escura passando pela região do olho. Corpo alto e boca terminal.

Altura do corpo contida 2,1 a $2,5^{*}$, do pedúnculo caudal 6,3 a $7,2 *$, comprimento da cabeça 2,7 a $3,2^{*}$ e do pedúnculo caudal 5,9 a $7,8^{*}$ vezes no $C P$. Comprimento do focinho contido 1,6 a 2,0*, diâmetro orbital 3,8 a 5,0* e distância interorbital 2,6 a 3,3* vezes no CC.

Nadadeira dorsal com XIV ou XV+10 a 12* raios, pélvica com 6, anal com III+9 ou $10 *$ e peitoral com 13 a 15* raios. Linha lateral interrompida, sendo o ramo superior com 17 a $20^{*}$ escamas perfuradas e o inferior com 8 a $14^{\star}$ escamas, linha transversal superior com $4^{*}$ e inferior com $5^{*}$ séries de escamas.

No reservatório de Segredo sua alimentação foi predominantemente de insetos, utilizando alternativamente outros itens, como vegetais, peixes e outros invertebrados (HAHN; FUGI; ALMEIDA; RUSSO; LOUREIRO, 1997). No reservatório de Salto Caxias a espécie também consumiu diversos itens, porém com predomínio de vegetais em sua dieta (DELARIVA, 2002). Seu período reprodutivo estende-se de setembro a janeiro (UNIVERSIDADE ESTADUAL DE MARINGÁ, 2002), sendo que os menores indivíduos em atividade reprodutiva foram registrados com $C P=43,0 \mathrm{~mm}$ nas fêmeas e $C P=47,0$ mm nos machos (UNIVERSIDADE ESTADUAL DO OESTE DO PARANÁ, 2008b, 2009b).

Sua distribuição geográfica engloba bacias costeiras do leste e sudeste do Brasil e do Uruguai e bacia do alto rio Paraná (BUCKUP; TEIXEIRA, 2007), sendo ainda registrada sua ocorrência no baixo rio Iguaçu (GARAVELLO; PAVANELLI; SUZUKI, 1997; BAUMGARTNER; BAUMGARTNER; PAVANELLI; SILVA; FRANA; OLIVEIRA; MICHELON, 2006).

*Loyola (2005) 
- Oreochromis niloticus (Linnaeus, 1758)

Tilápia-do-Nilo

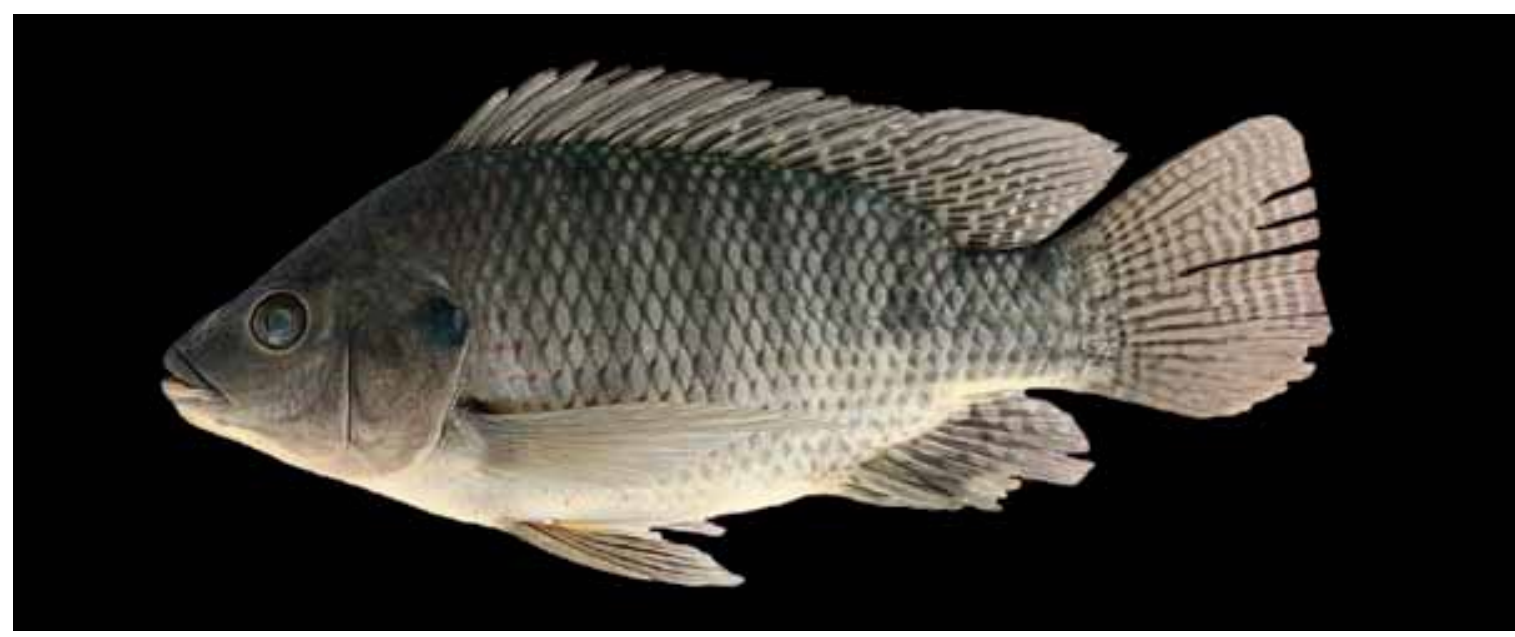

Comprimento padrão 213,6 mm

Corpo cinza-claro, com faixas cinza-escuras transversais e mancha preta na extremidade posterior do opérculo. Nadadeiras esbranquiçadas, sendo a pélvica e a peitoral com pigmentos escuros dispersos, enquanto a anal, caudal e porção posterior da dorsal com pintas castanho-escuras unidas, formando listras transversais, mais nítidas na caudal às vezes com pintas e ou manchas esbranquiçadas entre as listras. Boca terminal, olho grande, corpo alto e comprimido.

Altura do corpo contida 2,3 a $2,9^{*}$, do pedúnculo caudal 6,3 a $7,3^{*}$, comprimento da cabeça 2,7 a $3,2^{\star}$ e do pedúnculo caudal 7,0 a $10,0^{*}$ vezes no $C P$. Comprimento do focinho contido 2,5 a 3,3* diâmetro orbital 3,1 a 5,0* e distância interorbital 2,2 a 3,2 vezes no CC.

Nadadeira dorsal com XVII ou XVIII+11 a 15* raios, pélvica com I+5*, anal com III +8 a $10^{*}$ e peitoral com 14 a $16^{*}$ raios. Linha lateral interrompida, sendo o ramo superior com 21 a $23^{*}$ escamas perfuradas e o inferior com 13 a $16^{*}$ escamas, linha transversal superior com 4 ou $5^{\star}$ e inferior com 8 a 12* séries de escamas.

Espécie originária de rios africanos, foi introduzida na América do Sul para fins de atividades aquícolas, mas não na bacia do rio Iguaçu, onde provavelmente sua ocorrência seja oriunda de escape de pisciculturas. 
- Tilapia redalli (Boulenger, 1897)

Tilápia

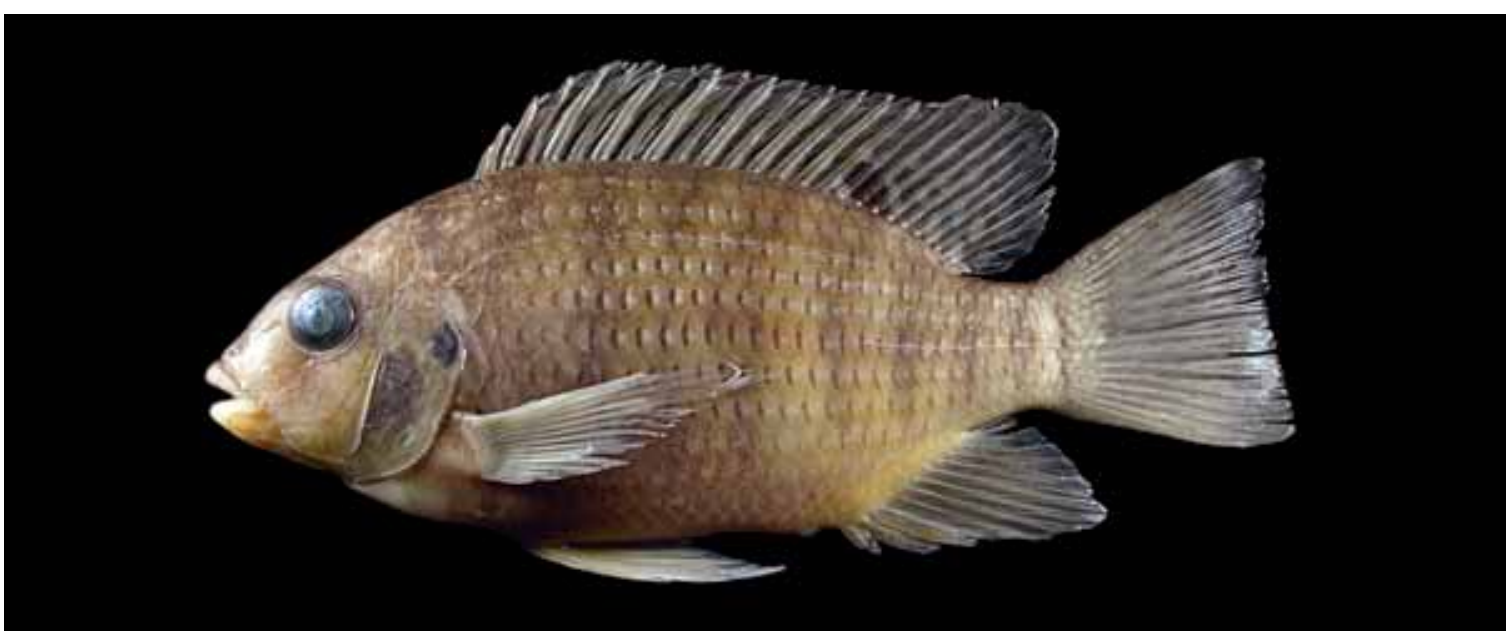

Comprimento padrão 99,0 mm

Corpo cinza-claro, com faixas cinza-escuras transversais e mancha preta na extremidade posterior do opérculo e muitas vezes também na base da nadadeira dorsal. Nadadeiras peitoral, pélvica e anal hialinas, com pigmentos escuros dispersos, e nadadeira dorsal e caudal às vezes com pintas castanhas, nunca formando listras. Boca terminal, olho grande, corpo alto e comprimido.

Altura do corpo contida 2,4 a $2,8^{*}$, do pedúnculo caudal 6,1 a $7,2 *$, comprimento da cabeça 2,8 a $3,3^{*}$ e do pedúnculo caudal 6,5 a $7,5^{*}$ vezes no CP. Comprimento do focinho contido 2,3 a 2,9* diâmetro orbital 2,0 a 4,6* e distância interorbital 2,4 a 3,8 vezes no CC.

Nadadeira dorsal com XV a XVI+11 a 13* raios, pélvica com 6*, anal com III+8 a $10^{*}$ e peitoral com 11 a $13^{*}$ raios. Linha lateral interrompida, sendo o ramo superior com 20 a $21^{*}$ escamas perfuradas e o inferior com 11 a $14^{*}$ escamas, linha transversal superior com 3,5 a 4,5* e inferior com 5 a $7^{*}$ séries de escamas.

Espécie originária de rios africanos, foi introduzida na América do Sul para fins de atividades aquícolas, mas não na bacia do Iguaçu, onde provavelmente sua ocorrência seja oriunda de escape de pisciculturas.

*Graça e Pavanelli (2007) 



\section{Glossário}

Acúleo: raio duro de nadadeira, formando um espinho forte, às vezes pungente, perfurante, outras vezes de ponta arredondada, podendo apresentar serrilhas ou odontódeos em uma ou em ambas as margens.

aff.: partícula utilizada para referir-se a uma espécie afim de outra, parecida com aquela, mas sabidamente diferente, e que não possui nome científico disponível.

Arco branquial: estrutura cartilaginosa em forma de arco, que suporta os filamentos (margem externa) e os rastros (margem interna) branquiais.

Barbilhão maxilar: cuja base é inserida na região do osso maxilar, que se origina logo acima do canto da boca.

Barbilhão mentoniano: localizado na região inferior da mandíbula. Geralmente, existem dois pares de barbilhões mentonianos; o par anterior ou mediano é denominado mentoniano, e o posterior ou lateral é chamado de pós-mentoniano.

Barbilhão nasal: localizado na abertura nasal ou narina.

Barbilhão rictal: localizado no canto da boca ou do lábio, originando-se próximo e logo abaixo da base do barbilhão maxilar.

Barbilhão: apêndice carnoso e filamentoso em forma de filamento olfativo ou gustativo presente em peixes de couro (Siluriformes) ou nas carpas (Cypriniformes). Apresenta-se em pares, podendo localizar-se próximo a diferentes estruturas da cabeça dos peixes. Possui formas e comprimentos que variam muito de acordo com o grupo ou com a espécie do peixe.

Bentônico: que habita regiões muito próximas ao sedimento ou substrato do ambiente aquático.

Bexiga natatória: estrutura membranosa localizada entre os rins e o trato digestório nos peixes ósseos. Tem função hidrostática e pode atuar como órgão respiratório acessório em algumas espécies de peixes.

Boca protrátil: composta de ossos móveis, com capacidade de se projetarem para frente, ampliando muito a cavidade bucal.

Boca subterminal: cuja fenda bucal é situada pouco abaixo/atrás do plano transversal que passa pela extremidade mais anterior da cabeça.

Boca superior: cuja abertura é voltada para região superior da cabeça, acima/atrás do plano transversal que passa pela extremidade mais anterior da cabeça.

Boca terminal: cuja abertura é situada na região mais anterior da cabeça.

Boca ventral: situada ventralmente, ou seja, na região inferior da cabeça.

Brânquia: estrutura composta pelos filamentos branquiais, na margem externa do arco branquial, os quais são responsáveis pela oxigenação do sangue, ou seja, é o órgão respiratório dos peixes.

Caracteres merísticos: dados contáveis dos organismos, por exemplo, número de dentes, número de escamas, número de raios, entre outros.

Caracteres morfométricos: dados mensuráveis dos organismos, por exemplo, comprimento padrão, distância pré-dorsal, largura da cabeça, entre outros. 
cf.: partícula utilizada para referir-se a indivíduos provavelmente da espécie nomeada, que, por algum motivo não se tem certeza, sugerindo a necessidade de se conferir.

Comprimido: achatado látero-lateralmente.

Côncavo: cuja superfície é cavada.

Conspícuo: nítido, bem visível.

Convexo: cuja superfície é abaulada.

Cópula: acasalamento; união de um indivíduo macho e uma fêmea para possibilitar a junção dos gametas (fecundação).

Coracoides: par de ossos da cintura escapular, que corresponde à cintura na qual se inserem as nadadeiras peitorais.

Corpo discoide: em forma de disco.

Corpo fusiforme: em forma de fuso, alongado, em forma de torpedo.

Cuidado parental: cuidado executado pelos pais para a proteção de seus descendentes, podendo incluir desde a fase de ovo até jovem.

Dentário: osso da maxila inferior, ou mandíbula, que pode ser provido ou não de dentes.

Dentes caninos: dentes de forma cônica, porém longos, fortes e pontiagudos, adaptados para penetrar e segurar a presa.

Dentes cônicos: dentes pequenos, em forma de cone.

Dentes cuspidados: dentes com a borda cortante composta por duas ou mais pontas (cúspides) ou saliências.

Dentes depressíveis: dentes móveis, não fixados integralmente de maneira rígida no osso, que, em contato com alimento, podem mudar da posição repousada para eriçada.

Dentes espatulados: dentes achatados, em forma de espátulas, adaptados para raspar superfícies.

Dentes incisiviformes: dente similar ao dente incisivo humano (dentes anteriores); dente de coelho.

Deprimido: achatado dorso-ventralmente.

Dimorfismo sexual: diferença morfológica e/ou comportamental perceptível externamente entre machos e fêmeas da mesma espécie, podendo incluir a formação de estruturas para cópula ou coorte, porte, padrão de colorido, estruturas utilizadas para reconhecimento de sexos, entre outras.

Distância interorbital: distância entre as bordas internas dos olhos, excluindo a membrana orbital.

Distância pré-anal: distância entre a extremidade anterior do focinho e o início da nadadeira anal.

Distância pré-dorsal: distância entre a extremidade anterior do focinho e a base do primeiro raio da nadadeira dorsal.

Distância pré-peitoral: distância entre a extremidade anterior do focinho e a origem da nadadeira peitoral.

Entalhe na nadadeira dorsal: concavidade na borda da nadadeira, situada entre a porção de raios duros (espinhos) e a de raios moles.

Espécie endêmica: encontrada exclusivamente em um determinado local.

Espinho: raio de nadadeira duro, pungente, perfurante (não serrilhado). 
Falcada: em forma de faca; de borda oblíqua, inclinada.

Família: categoria taxonômica utilizada para agrupar gêneros com características semelhantes.

Fecundação: encontro dos gametas masculino e feminino (espermatozoide e ovócito).

Fecundação externa: fecundação ocorrida fora do corpo da fêmea, após o macho e a fêmea expelirem seus gametas na água.

Fecundação interna: fecundação ocorrida dentro do corpo das fêmeas, após a cópula.

Filamento carnoso: apêndice carnoso em forma de fita, geralmente aderido ao dorso de espécies da família Apteronotidae.

Flanco: região lateral do corpo.

Fontanela: abertura na superfície mediana do teto do crânio, moleira. Quando situada entre os ossos frontais é chamada fontanela frontal e quando entre os ossos parietais chama-se fontanela parietal.

Gametas: células sexuais dos peixes (espermatozoide do macho, ovócito da fêmea), que se unem durante a fecundação para formar o ovo.

Gênero: categoria taxonômica utilizada para agrupar espécies com características semelhantes e um único ancestral comum.

Gonopódio: modificação da nadadeira anal em órgão copulador nos machos.

Herbívoro: que se alimenta de vegetais.

Hialino: transparente, translúcido, que deixa passar a luz.

Ictiofauna: fauna de peixes.

Incertae sedis: conjunto de gêneros e/ou de espécies que não possuem suas relações de parentesco estudadas a contento ou conclusivamente, nem possuem um conjunto de caracteres únicos para qualificá-los como determinada categoria taxonômica, como família ou subfamília, por exemplo.

Inconspícua: não nítida, pouco visível.

Infraorbitais: série de ossos achatados que circundam a órbita inferiormente.

Insetívoro: que se alimenta de insetos.

Interopérculo: osso do aparelho opercular situado sob o pré-opérculo.

Invertívoro: que se alimenta de invertebrados.

Istmo: região mais estreita entre as bordas inferiores das membranas branquiais situadas na porção ventral da cabeça.

Jusante: abaixo de um determinado local.

Linha lateral: canal estreito sobre a região lateral do corpo, perfurado em determinados intervalos para penetração da água, e com células sensoriais, funcionando como um "radar", ao perceber vibrações e alterações de pressão na água.

Linha longitudinal: escamas da linha que inclui a lateral, nos casos em que ela é interrompida ou incompleta. Quando ela é ausente, a linha longitudinal é o número de escamas na série de escamas mais longa da lateral do tronco.

Linha transversal: séries de escamas localizadas acima e abaixo da linha lateral. A superior geralmente é contada na região de inserção do primeiro raio da nadadeira dorsal, e a inferior pode ser na inserção do primeiro raio da nadadeira pélvica ou da anal.

Lóbulo branquial: estrutura cartilaginosa arredondada, podendo ou não apresentar rastros, presente na parte superior do arco branquial de algumas espécies da família Cichlidae. 
Localidade-tipo: local em que o exemplar-tipo da espécie foi coletado.

Mancha umeral: Concentração de pigmentos formando uma mancha localizada na região umeral (acima da nadadeira peitoral).

Mandíbula: conjunto de ossos da parte inferior da boca, maxila inferior.

Maxilas: conjunto de ossos da parte superior (maxila superior) e inferior (maxila inferior ou mandíbula) da boca. A maxila superior é formada por um par de ossos pré-maxilares fundidos anteriormente e um par de ossos maxilares, um de cada lado. A maxila inferior é composta por três pares de ossos, dentários, articulares e angulares.

Migrações: movimentos realizados pelos peixes, podendo ser para fins reprodutivos ou alimentares, de uma região para outra.

Montante: acima de um determinado local.

Nadadeira adiposa: nadadeira ímpar, geralmente sem raios de sustentação, localizada na região dorsal do corpo, atrás da nadadeira dorsal.

Nadadeira anal - nadadeira ímpar localizada na região ventral do indivíduo, logo após o ânus.

Nadadeira arredondada: com a margem posterior arredondada.

Nadadeira bifurcada: dividida em dois lobos separados por um entalhe em forma de forquilha, sendo um superior e outro inferior.

Nadadeira caudal: nadadeira ímpar localizada na extremidade posterior do peixe.

Nadadeira dorsal: nadadeira localizada na região dorsal do indivíduo. Geralmente é ímpar, mas pode apresentar-se dividida em duas partes separadas, ou unidas por um entalhe.

Nadadeira peitoral: em número de duas localizadas logo após a cabeça.

Nadadeira pélvica ou ventral: em número de duas localizadas na região ventral, anteriormente ao ânus.

Nadadeira truncada: com a margem posterior reta.

Nadadeira: apêndice locomotor dos peixes, constituída de raios ósseos unidos por membranas chamadas interradiais. Podem ser pares (peitorais e pélvicas) ou ímpares (dorsal, adiposa, anal e caudal).

Ocelo: Mancha em forma de olho, que geralmente tem por função enganar os predadores. Compõe-se de uma região arredondada escura, circundada por uma área estreita clara.

Odontódeos: dentículos dérmicos que podem variar em número, forma e rigidez de acordo com a espécie, sexo, local do corpo ou período reprodutivo.

Onívoro: que se alimenta de material animal e vegetal, de diversas origens.

Opérculo: maior osso do aparelho opercular, que recobre a cavidade branquial.

Órbita: cavidade onde se aloja o olho.

Ordem: categoria taxonômica que agrupa as famílias com características semelhantes.

Osso frontal: osso do teto do crânio, situado entre as órbitas.

Osso maxilar: em número de dois, situados lateralmente na maxila superior, articulados com os ossos pré-maxilares.

Osso pré-maxilar: em número de dois, fundidos anteriormente, articulados lateralmente com os maxilares.

Ossos parietais: par de ossos da porção posterior do teto do crânio, situados atrás dos frontais e à frente do supraocciptal. 
Palato: superfície superior da cavidade bucal, atrás dos pré-maxilares, constituída de vários ossos; "céu-da-boca".

Papilas: órgãos sensoriais em forma de pequenos botões que podem estar distribuídos em diferentes partes do corpo, principalmente nos lábios.

Pedúnculo caudal: região entre a origem do último raio da nadadeira anal e a origem da nadadeira caudal.

Pelágicos: que habitam a coluna d'água.

Piscívoro: que se alimenta de peixes.

Placa dentígera: agrupamento de dentes pequenos e numerosos, formando uma placa óssea que pode ser situada em várias regiões da boca e faringe.

Planície de inundação: terrenos baixos e planos irrigados por rios que, em períodos de seca, apresentam um leito definido e várias lagoas, e, em períodos de cheia, são parcial ou totalmente inundados.

Pré-opérculo: osso do aparelho opercular situado à frente do opérculo e sobre o interopérculo.

Processo supraoccipital: projeção do osso supraoccipital, na região mediana dorsal.

Prognata: alongada e proeminente, mais longa que a outra maxila.

Protrátil: que pode se protrair, ou alongar-se para fora.

Pungente: com ponta dura e fina; perfurante; que espeta.

Quilha: seção afilada em forma de V, geralmente localizada na região ventral.

Raios das nadadeiras: estruturas ósseas que dão sustentação às nadadeiras.

Raios procorrentes: situados à frente e em sequência aos raios principais da nadadeira caudal, na linha mediana ventral e dorsal.

Região gular: parte inferior da cabeça.

Região proximal: mais próxima do eixo central do corpo.

Região umeral: parte anterior mediana do flanco, logo atrás do opérculo.

Região Neotropical: região zoogeográfica do Sul do México até o Norte da Argentina.

Sínfise: linha mediana da mandíbula, onde os ossos dentários, esquerdo e direito, se juntam.

sp.: partícula utilizada quando não se consegue identificar o nome da espécie em questão ou quando a espécie é nova, ou seja, ainda não possui nome científico formalmente publicado.

Tubérculos nupciais: estruturas dérmicas em forma de botões, presentes principalmente em algumas regiões da cabeça e parte anterior do tronco, geralmente mais desenvolvidas em indivíduos no período de reprodução.

Ventosa: estrutura circular que, através de sucção, proporciona aderência ao substrato.

Ventre quilhado: região abdominal em forma de quilha.

Vivípara: espécie cuja reprodução se dá por fecundação interna e cujo desenvolvimento dos filhotes também é interno, e, ao nascerem, os filhotes são bastante semelhantes aos adultos. 


\section{Referências}

ABELL, R.; THIEME, M.L.; REVENGA, C.; BRYER, M.; KOTTELAT, M.; BOGUTSKAYA, N.; COAD, B.; MANDRAK, N.; CONTRERAS BALDERAS, S.; BUSSING, W.; STIASSNY, M.L.J.; SKELTON, P.;. ALLEN, G. R.; UNMACK, P.; NASEKA, A.; REBECCA, N.G.; SINDORF, N.; ROBERTSON, J.; ARMIJO, E.; HIGGINS, J.V.; HEIBEL, T.J.; WIKRAMANAYAKE, E.; OLSON, D.; LÓPEZ, H. L.; REIS, R.E.; LUNDBERG, J.G.; SABAJ PÉREZ, M.H.; PETRY, P. Freshwater ecoregions of the World: a new map of biogeographic units for freshwater biodiversity conservation. BioScience, Washington, D.C., v. 58, no. 5, p. 403-414, 2008.

ABILHOA, V.; DUBOC, L.F. Peixes. In: MIKICH, S.B.; BÉRNILS, R.S. (Ed.). Livro vermelho da fauna ameaçada no estado do Paraná. Curitiba: Instituto Ambiental do Paraná, 2004. p. 581678.

ABUCARMA, M.; MARTINS-SANTOS, I.C. Karyotype and B chromosome of Rhamdia species (Pisces, Pimelodidae) endemic in the River Iguaçu basin. Cytologia, Tokyo, v. 66, p. 299-306, 2001.

AGOSTINHO, A.A.; GOMES, L.C. (Ed.). Reservatório de Segredo: bases ecológicas para o manejo. Maringá, PR: Eduem: Nupélia, 1997. 387 p., il.

AGOSTINHO, A.A.; HAHN; N.S.; GOMES, L.C.; BINI, L.M. Estrutura trófica. In: VAZZOLER, A.E.A. de M.; AGOSTINHO, A.A.; HAHN, N.S. (Ed.). A planície de inundação do alto rio Paraná: aspectos físicos, biológicos e socioeconômicos. Maringá : Eduem: Nupélia, 1997. cap. II.6, p. 229-248.

ALBERT, J.S.; CRAMPTON, W.G.R. Seven new species of the Neotropical electric fish Gymnotus (Teleostei, Gymnotiformes) with a redescription of G. carapo (Linnaeus). Zootaxa, Auckland, v. 287, p. 1-54, 2003.

ALCARAZ, H.S.V.; PAVANELLI, C.S.; BERTACO, V.A. Astyanax jordanensis (Ostariophysi: Characidae), a new species from the rio Iguaçu basin, Paraná, Brazil. Neotropical Ichthyology, Porto Alegre, v. 7, no. 2, p. 185-190, 2009.

ALMIRÓN, A.E.; AZPELICUETA, M. de las M.; CASCIOTTA, J.R. Astyanax ita sp. n. - a new species from the Río Iguazú basin, in Argentina (Teleostei, Characiformes, Characidae). Zoologische Abhandlungen, Dresden, (Bd. 52), p. 5-12, 2002.

ALMIRÓN, A.E.; AZPELICUETA, M. de las M.; CASCIOTTA, J.R. A new species of Epactionotus (Siluriformes: Loricariidae: Otothyrini) from the río Iguazú basin, Argentina. Zoologische Abhandlungen, Dresden, (Bd. 54), p. 137-144, 2004.

AMORIM, S.E.; MENEZES, N.A. Família Synbranchidae. In: BUCKUP, P.A.; MENEZES, N.A.; GHAZZI, M.S. (Ed.). Catálogo das espécies de peixes de água doce do Brasil. Rio de Janeiro: Museu Nacional, 2007. p. 138. (Série Livros, 23).

ANDRIAN, I.F.; DÓRIA, C.R.C.; TORRENTE, G.; FERRETTI, C.M.L. Espectro alimentar e similaridade na composição da dieta de quatro espécies de Leporinus (Characiformes, Anostomidae) do rio Paraná ( $\left.22^{\circ} 10^{\prime}-22^{\circ} 50^{\prime} \mathrm{S}-53^{\circ} 10^{\prime}-53^{\circ} 40^{\prime} \mathrm{W}\right)$, Brasil. Revista UNIMAR, Maringá, v. 16, supl.3, p. 97-106, 1994.

ARMBRUSTER, J.W. Phylogenetic relationships of the suckermouth armoured catfishes (Loricariidae) with emphasis on the Hypostominae and the Ancistrinae. Zoological Journal of the Linnean Society, London, v. 141, p. 1-80, 2004.

AZEVEDO, L.C. Análise da precipitação pluvial da bacia do rio Iguaçu-Paraná. Maringá, 2006. 109 f., il. Dissertação (Mestrado em Geografia) - Universidade Estadual de Maringá, Maringá, 2006.

AZPELICUETA, M. de las M.; CASCIOTTA, J.R.; ALMIRÓN, A.E. Bryconamericus pyahu sp. n. (Characiformes, Characidae), a new species from the río Iguazú basin, in Argentina. Revue Suisse de Zoologie, Genève, v. 110, no. 3, p. 581-589, 2003.

AZPELICUETA, M. de las M.; CASCIOTTA, J.R.; ALMIRÓN, A.E. Two new species of the genus Astyanax (Characiformes, Characidae) from the Paraná basin in Argentina. Revue Suisse de Zoologie, Genève, v. 109, no. 2, p. 243-259, 2002. 
BAUMGARTNER, D.; BAUMGARTNER, G.; PAVANELLI, C.S.; SILVA, P.R.L.; FRANA, V.A.; OLIVEIRA, L.C.; MICHELON, M.R. Fish, Salto Osório Reservoir, rio Iguaçu basin, Paraná State, Brazil. Check List (UNESP), São Paulo, v. 2, n. 1, p. 1-4, 2006.

BEMVENUTI, M.A. Diferenciação morfológica das espécies de peixes-rei, Odontesthes Evermann \& Kendall (Osteichthyes, Atherinopsidae) no extremo sul do Brasil: morfometria multivariada. Revista Brasileira de Zoologia, São Paulo, v. 19, n. 1, p. 251-287, 2002.

BIFI, A.G.; BAUMGARTNER, D.; BAUMGARTNER, G.; FRANA, V.A.; DEBONA, T. Composição específica e abundância da ictiofauna do rio dos Padres, bacia do rio Iguaçu, Brasil. Acta Scientiarum. Biological Sciences, Maringá, v. 28, no. 3, p. 203-211, 2006.

BIFI, A.G.; PAVANELLI, C.S.; ZAWADZKI, C.H. Three new species of Ancistrus Kner, 1854 (Siluriformes: Loricariidae) from the Rio Iguaçu basin, Paraná State, Brazil. Zootaxa, Auckland, no. 2275, p. 41-59, 2009.

BOCKMANN, F.A.; GUAZZELLI, G.M. Family Heptapteridae (Heptapterids). In: REIS, R.E.; KULLANDER, S.O.; FERRARIS, C.J., Jr. (Org.). Check list of the freshwater fishes of South and Central America. Porto Alegre: EDIPUCRS, 2003. p. 406-431.

BRITSKI, H.A.; GARAVELLO, J.C. Família Anostomidae. In: BUCKUP, P.A.; MENEZES, N.A.; GHAZZI, M.S. (Ed.). Catálogo das espécies de peixes de água doce do Brasil. Rio de Janeiro: Museu Nacional, 2007. p. 23-27. (Série Livros, 23).

BRITSKI, H.A.; GARAVELLO, J.C. Sobre Leporinus octofasciatus Steindachner da bacia do Paraná (Pisces, Anostomidae). Papéis Avulsos de Zoologia (São Paulo), v. 31, n. 16, p. 237-250, 1978.

BRITSKI, H.A.; SILIMON, K.Z.S.; LOPES, B.S. Peixes do Pantanal: manual de identificação. Ilustrações Álvaro Evandro X. Nunes. 2. ed. rev. e ampl. Brasília, DF: Embrapa Informacão Tecnológica, 2007. 230 p., il.color.

BRITTO, M.R. Família Callichthyidae. In: BUCKUP, P.A.; MENEZES, N.A.; GHAZZI, M.S. (Ed.). Catálogo das espécies de peixes de água doce do Brasil. Rio de Janeiro: Museu Nacional, 2007. p. 75-81. (Série Livros, 23).

BUCKUP, P.A.; MENEZES, N.A.; GHAZZI, M.S. (Ed.). Catálogo das espécies de peixes de água doce do Brasil. Rio de Janeiro: Museu Nacional, 2007. 195p.

BUCKUP, P.A. Family Crenuchidae (South American darters). In REIS, R.E.; KULLANDER, S.O., FERRARIS, C.J., Jr. (Org.). Check list of the freshwater fishes of South and Central America. Porto Alegre: EDIPUC RS, 2003. p. 87-95.

BUCKUP, P.A.; TEXEIRA, J.M.S. Família Cichlidae. In: BUCKUP, P.A.; MENEZES, N.A.; GHAZZI, M.S. (Ed.). Catálogo das espécies de peixes de água doce do Brasil. Rio de Janeiro: Museu Nacional, 2007. p. 139-148. (Série Livros, 23).

BUITRAGO-SUÁREZ, U.A.; BURR, B.M. Taxonomy of the catfish genus Pseudoplatystoma Bleeker (Siluriformes: Pimelodidae) with recognition of eight species. Zootaxa, Auckland, no. 1512, p. 1-38, 2007.

BURGESS, W.E. An atlas of freshwater and marine catfishes: a preliminary survey of the Siluriformes. Neptune City: T.F.H. Publications, c1989. 784 p., ill.

CAMPOS-DA-PAZ, R. Sistemática e taxonomia dos peixes elétricos das bacias dos rios Paraguai, Paraná e São Francisco, com notas sobre espécies presentes em rios costeiros do leste do Brasil (Teleostei: Ostariophysi: Gymnotiformes). São Paulo, 1997. 317 f., il. Tese (Doutorado em Ciências Biológicas, Área Zoologia) - Instituto de Biociência, Universidade de São Paulo, São Paulo, 1997.

CAMPOS-DA-PAZ, R.; BUCKUP, P.A. Família Gymnotidae. In: BUCKUP, P.A.; MENEZES, N.A.; GHAZZI, M.S. (Ed.). Catálogo das espécies de peixes de água doce do Brasil. Rio de Janeiro: Museu Nacional, 2007. p. 120-121. (Série Livros, 23).

CARVALHO, M.; BOCKMANN, F.A. Família Loricariidae: Hypostominae. In: BUCKUP, P.A.; MENEZES, N.A.; GHAZZI, M.S. (Ed.). Catálogo das espécies de peixes de água doce do Brasil. Rio de Janeiro: Museu Nacional, 2007. p. 91-98. (Série Livros, 23).

CASCIOTTA, J.; ALMIRÓN, A. Crenicichla tesay, a new species of cichid (Perciformes: Labroidei) from the río Iguazú basin in Argentina. Revue Suisse de Zoologie, Genève, v. 115, no. 4, p. 651-569, 2008. 
CASCIOTTA, J.R.; ALMIRÓN, A.E.; AZPELICUETA, M. de las M. Bryconamericus ikaa, a new species from tributaries of the río Iguazú in Argentina (Characiformes, Characidae). Ichthyological Explorations Freshwaters, München, v. 15, no. 1, p. 61-66, 2004.

CASCIOTTA, J.R.; ALMIRÓN, A.E.; GÓMEZ, S.E. A new species of Australoheros (Teleostei: Perciformes: Cichlidae), from the río Iguazú basin, Argentina. Zoologische Abhandlungen, Dresden, no. 55, p. 77-83, 2006 a.

CASCIOTTA, J.R.; ALMIRÓN, A.E.; GÓMEZ, S.E. Crenicichla yaha sp. n. (Perciformes: Labroidei: Cichidae), a new species from the rio Iguazú and Arroio Urugua-í basins, northeastern Argentina. Zoologische Abhandlungen, Dresden, no. 56, p. 107-112, $2006 \mathrm{~b}$.

CASTRO, R.M.C.; VARI, R.P. Detritivores of the South American fish family Prochilodontidade (Teleostei: Ostariophysi: Characiformes): a phylogenetic and revisionary study. Washington, D.C.: Smithsonian Institution, 2004. v, 189 p., ill. (Smithsonian Contributions to Zoology, no. 622)

CASTRO, R.M.C.; VARI, R.P. Família Prochilodontidae. In: BUCKUP, P.A.; MENEZES, N.A.; GHAZZI, M.S. (Ed.). Catálogo das espécies de peixes de água doce do Brasil. Rio de Janeiro: Museu Nacional, 2007. p. 23. (Série Livros, 23).

DELARIVA, R.L. Ecologia trófica da ictiofauna do rio Iguaçu-PR sob efeitos do represamento de Salto Caxias. Maringá, 2002. 65 f., il. Tese (Doutorado em Ecologia de Ambientes Aquáticos Continentais) - Universidade Estadual de Maringá, Maringá, 2002.

DELARIVA, R.L.; HAHN, N.S.; GOMES, L.C. Diet of a catfish before and after damming of the Salto Caxias Reservoir, Iguaçu River. Brazilian Archives of Biology and Technology, Curitiba, v. 50, no. 5, p. 767-775, 2007.

DYER, B.S. Family Atherinopsidae (Neotropical Silversides). In: REIS, R.E.; KULLANDER, S.O; FERRARIS, C.J., Jr. (Org.). Check list of the freshwater fishes of South and Central America. Porto Alegre: EDIPUCRS, 2003. p. 515-526.

ELETROSUL. O impacto ambiental da ação do homem sobre a natureza - rio Iguaçu, Paraná, Brasil: reconhecimento da ictiofauna, modificações ambientais e usos múltiplos dos reservatórios. Florianópolis, 1978, 33p.

ELLIS, M.D. II. On the species of Hasemania, Hyphessobrycon and Hemigrammus collected by J. D. Haseman for the Carnegie Museum. Annals of the Carnegie Museum, Pittsburgh, v. 8, no. 1-2, p. 148-163, 1911.

ETNIER, D.A.; STARNES, W.C. The fishes of Tennessee. Photographs by Richard T. Bryant and Wayne C. Starnes. Knoxville, Tennessee: University of Tennessee Press, c1993. 689 p., ill.col.

FERRARIS, C.J., Jr. Family Auchenipteridae (Driftwood catfishes). In: REIS, R.E.; KULLANDER, S.O.; FERRARIS, C.J., Jr. (Org.). Check list of the freshwater fishes of South and Central America. Porto Alegre: EDIPUCRS, 2003a. p. 470-482.

FERRARIS, C.J., Jr. Subfamily Loricariinae (Armored catfishes). In: REIS, R.E.; KULLANDER, S.O.; FERRARIS, C.J., Jr. (Org.). Check list of the freshwater fishes of South and Central America. Porto Alegre: EDIPUCRS, 2003b. p. 330-350.

FUGI, R.; HAHN, N.S.; AGOSTINHO, A.A. Feeding styles of five species of bottom-feeding fishes of the high Paraná River. Environmental Biology of Fishes, Dordrecht, v. 46, no. 3, p. 297 307, 1996.

GARAVELLO, J.C. Descrição de Apareiodon vittatus sp. n. do rio Iguaçu e comentários sobre as espécies do gênero Apareiodon Eigenmann, 1916 (Ostariophysi, Parodontidae). Revista Brasileira de Biologia, Rio de Janeiro, v. 37, n. 2, p. 447-455, 1977.

GARAVELLO, J.C. Revisão taxonômica do gênero Leporinus SPIX, 1829 (Ostariophysi, Anostomidae). São Paulo, SP, 1979. 451 f., il. Tese (Doutorado em Ciências, Área de Zoologia) Instituto de Biociências, Universidade de São Paulo, São Paulo, 1979.

GARAVELLO, J.C. Revision of genus Steindachneridion (Siluriformes: Pimelodidae).

Neotropical Ichthyology, Porto Alegre, v. 3, no. 4, p. 607-623, 2005.

GARAVELLO, J.C.; BRITSKI, H.A. Family Anostomidae (Headstanders). In: REIS, R.E.; KULLANDER, S.O.; FERRARIS, C.J., Jr. (Org.). Check list of the freshwater fishes of South and Central America. Porto Alegre: EDIPUCRS, 2003. p. 71-84.

GARAVELLO, J.C.; BRITSKI, H.A. Leporinus macrocephalus sp. n. da bacia do rio Paraguai (Ostariophysi, Anostomidae). Naturalia, São Paulo, v. 13, p. 67-74, 1988. 
GARAVELLO, J.C.; PAVANELLI, C.S.; SUZUKI, H.I. Caracterização da ictiofauna do rio Iguaçu. In: AGOSTINHO, A.A.; GOMES, L.C. (Ed.). Reservatório de Segredo: bases ecológicas para o manejo. Maringá: Eduem, 1997. cap. 4, p.[61]-84.

GARAVELLO, J.C.; SAMPAIO, F.A.A. Five new species of genus Astyanax Baird \& Girard, 1854 from Rio Iguaçu, Paraná, Brazil (Ostariophysi, Characiformes, Characidae). Brazilian Journal of Biology, São Carlos, v. 70, no. 3, p. 847-865, 2010.

GARAVELlO, J.C.; SHIBATTA, O.A. A new species of the genus Pimelodus La Cépède, 1803 from the rio Iguaçu basin and a reappraisal of Pimelodus ortmanni Haseman, 1911 from the rio Paraná system, Brazil (Ostariophysi: Siluriformes: Pimelodidae). Neotropical Ichthyology, Porto Alegre, v. 5, no. 3, p. 285-292, 2007.

GARUTTI, V., BRITSKI, H. A. Descrição de uma espécie nova de Astyanax (Teleostei: Characidae) da bacia do Alto rio Paraná e considerações sobre as demais espécies do gênero na bacia. Museu de Ciências e Tecnologia da PUCRS. Série Zoologia, Porto Alegre, v. 13, p. 65 $88,2000$.

GÉRY, J. Characoids of the world. Neptune City: T.F.H. Publications, c1977. 672 p., ill. (some col.).

GHAZZI, M.S.; OYAKAWA, O.T. Família Loricariidae: Loricariinae. In: BUCKUP, P.A.; MENEZES, N.A.; GHAZZI, M.S. (Ed.). Catálogo das espécies de peixes de água doce do Brasil. Rio de Janeiro: Museu Nacional, 2007. p. 87-91. (Série Livros, 23).

GHEDOTTI, M.J. Family Anablebidae (Four-eyed fishes, onesided livebearers and the white eye). In: REIS, R.E.; KULLANDER, S.O.; FERRARIS, C.J., Jr. (Org.). Check list of the freshwater fishes of South and Central America. Porto Alegre: EDIPUCRS, 2003. p. 582-585.

GIORA, J.; FIALHO, C.B. Biologia alimentar de Steindachnerina brevipinna (Characiformes, Curimatidae) do rio Ibicuí-mirim, Rio Grande do Sul, Brasil. Iheringia, Série Zoologia, Porto Alegre, v. 93, n. 3, p. 277-281, 2003.

GÓMEZ, S.E.; LÓPEZ, H.L.; TORESANI, N I. Hypostomus derbyi (Haseman) e Hypostomus myersi (Gosline), descripción complementaria y primeros registros para Argentina (Pisces, Loricariidae). Studies on Neotropical Fauna and Environment, Lisse, v. 25, no. 3, p. 139-152, 1990.

GRAÇA, W.J.; PAVANELLI, C.S. Astyanax altiparanae Garutti \& Britski, 2000 (Osteichthyes, Characidae) in the Iguaçu River basin. Acta Scientiarum, Maringá, v. 24, no. 2, p. 451-453, 2002.

GRAÇA, W.J.; PAVANELLI, C.S. Peixes da planície de inundação do alto rio Paraná e áreas adjacentes. Maringá: Eduem, 2007. 241 p., il. color.

GUBIANI, E.A.; FRANA, V.A.; MACIEL, A.L; BAUMGARTNER, D. Occurrence of the nonnative fish Salminus brasiliensis (Cuvier, 1816), in a global biodiversity ecoregion, Iguaçu River, Paraná River basin, Brazil. Aquatic Invasions, Ballinode, v. 5, no. 2, p. 223-227, 2010.

HAHN, N.S.; ANDRIAN, I.F.; FUGI, R.; ALMEIDA, V.L.L. Ecologia trófica. In: VAZZOLER, A.E.A. de M.; AGOSTINHO, A.A.; HAHN, N.S. (Ed.). A planície de inundação do alto rio Paraná: aspectos físicos, biológicos e socioeconômicos. Maringá: Eduem: Nupélia, 1997. cap. II.5, p. [209]-228.

HAHN, N.S.; FUGI, R.; ALMEIDA, V.L.L.; RUSSO, M.R.; LOUREIRO, V.E. Dieta e atividade alimentar de peixes do reservatório de Segredo. In: AGOSTINHO, A.A.; GOMES, L.C. (Ed.). Reservatório de Segredo: bases ecológicas para o manejo. Maringá: Eduem, 1997. cap. 8, p. 141162.

HAHN, N.S.; FUGI, R.; ANDRIAN, I.F. Trofic ecology of the fish assemblages. In: THOMAZ, S.M.; AGOSTINHO, A.A.; HAHN, N.S. (Ed.). The Upper Paraná River and its floodplain: physical aspects, ecology and conservation. Leiden, The Netherlands: Backhuys Publishers, 2004. ch. 11, p. [247]-269. (Biology of inland waters).

HAHN, N.S.; FUGI, R.; LOURERO-CRIPPA, V. E.; PERETTI, D.; RUSSO, M.R. Trophic structure of the fish fauna. In: AGOSTINHO, A.A.; RODRIGUES, L.; GOMES, L. C.; THOMAZ, S. M.; MIRANDA, L. E. (Ed.). Structure and functioning of the Paraná River and its floodplain LTER-Site 6 (PELD-Sítio 6). Maringá: Eduem, 2004. p.[139]-143.

HALUCH, C.F.; ABILHOA, V. Astyanax totae, a new characid species (Teleostei: Characidae) from the upper rio Iguaçu basin, southeastern Brazil. Neotropical Ichthyology, Porto Alegre, v. 3, no. 3, p. 383-388, 2005. 
HANSSENS, M. A review of the Clarias species (Pisces; Siluriformes) from the Lower Congo and the Pool Malebo. Journal of Afrotropical Zoology, Tervuren, v. 5, p. 27-40, 2009.

HASEMAN, J. D. An annotated catalog of the cichlid fishes collected by the expedition of the Carnegie Museum to central South America, 1907-10. Annals of the Carnegie Museum, Pittsburgh, v. 7, nos. 3-4, p. 329-373, 1911a.

HASEMAN, J. D. Some new species of fishes from the Rio Iguassú. Annals of the Carnegie Museum, Pittsburgh, v. 7, nos. 3-4, p. 374-387, 1911 b.

HAUCK, P. Origens e evolução da Serra do Mar. Disponível em: <http://altamontanha.com/ colunas.asp?newsID=1448>. Publicado em: 2 de jun. 2009. Acesso em: 07 de mar. 2012.

INGENITO, L.F.S.; DUBOC, L.F.; ABILHOA, V. Contribuição ao conhecimento da ictiofauna da bacia do alto rio Iguaçu, Paraná, Brasil. Arquivos de Ciências Veterinárias e Zoologia da UNIPAR, Umuarama, v. 7, n. 1, p. 23-36, 2004.

INGENITO, L.F.S.; GHAZZI, M.S.; DUBOC, L.F.; ABILHOA, V. Two new species of Rineloricaria (Siluriformes: Loricariidae) from the rio Iguaçu basin, southern Brazil. Neotropical Ichthyology, Porto Alegre, v. 6, no. 3, p. 355-366, 2008.

INSTITUTO PARANAENSE DE DESENVOLVIMENTO ECONÔMICO E SOCIAL (IPARDES). Indicadores ambientais por bacias hidrográficas do Estado do Paraná. Curitiba: 2010. 223 p.

JÉGU, M. Subfamily Serrasalminae (Pacus and piranhas). In: REIS, R.E.; KULLANDER, S.O.; FERRARIS, C.J., Jr. (Org.). Check list of the freshwater fishes of South and Central America. Porto Alegre: EDIPUCRS, 2003. p. 182-196.

JÉGU, M.; INGENITO, L.F. S. Família Characidae: Serrasalminae. In: BUCKUP, P.A.; MENEZES, N.A.; GHAZZI, M.S. (Ed.). Catálogo das espécies de peixes de água doce do Brasil. Rio de Janeiro: Museu Nacional, 2007. p. 40-43. (Série Livros, 23).

JÚLIO JÚNIOR, H.F.; BONECKER, C.; AGOSTINHO, A.A. Reservatório de Segredo e sua inserção na bacia do rio Iguaçu. In: AGOSTINHO, A. A.; GOMES, L.C. (Ed). Reservatório de Segredo: bases ecológicas para o manejo. Maringá: Eduem, 1997. cap. 1, p. 1-17.

KOLAR, C.S; CHAPMAN, D.C.; COURTENAY W.R., Jr.; HOUSEL, C.M.; WILLIAMS, J.D.; JENNYNGS, D.P. Asian carps of the genus Hypophthalmichthys (Pisces, Cyprinidae): a biological synopsis and environmental risk assessment. Washington, D.C.: U.S. Fish and Wildlife Service, 2005. vi, 175 p., ill. col. (Report to per Interagency Agreement 94400-3-0128).

KULLANDER, S.O. A revision of the South American cichlid genus. Cichlasoma. (Teleostei: Cichlidae). Stockholm: Swedish Museum of Natural History, 1983. 296 p.

KULLANDER, S.O. Family Cichlidae (Cichlids). In: REIS, R.E.; KULLANDER, S.O.; FERRARIS, C.J., Jr. (Org.). Check list of the freshwater fishes of South and Central America. Porto Alegre: EDIPUCRS, 2003a. p. 605-654.

KULLANDER, S.O. Family Synbranchidae (Swamp-eels). In: REIS, R.E.; KULLANDER, S.O.; FERRARIS, C.J., Jr. (Org.). Check list of the freshwater fishes of South and Central America. Porto Alegre: EDIPUCRS, 2003b. p. 594-595.

KULLANDER, S.O.; FERREIRA, E.J.G. A review of the South American Cichlid genus Cichla, with descriptions of nine new species (Teleostei: Cichlidae). Ichthyological Exploration of Freshwaters, München, v. 17, no. 4, p. 289-398, 2006.

LAMPERT, V.R.; AZEVEDO, M.A.; FIALHO, C.B. Hábito alimentar de Mimagoniates microlepis Steindachner, 1876 (Characidae: Glandulocaudinae) do canal de ligação entre as lagoas Emboaba e Emboabinha, Rio Grande do Sul, Brasil. Comunicações do Museu de Ciências e Tecnologia da PUCRS, Série Zoológica, Porto Alegre, v. 16, p. 3-16, 2003.

LIMA, F.C.T. Revisão taxonômica do gênero Brycon Mueller \& Troschel, 1844, dos rios da América do Sul cisandina (Pisces, Ostariophysi, Characiformes, Characidae). São Paulo, SP, 2001. 294 f., il.. Dissertação (Mestrado em Ciências Biológicas, Área de Zoologia) - Instituto de Biociências, Universidade de São Paulo, São Paulo, 2001.

LIMA, F.C.T. Subfamily Bryconinae (Characins, tetras). In: REIS, R.E.; KULLANDER, S.O.; FERRARIS, C.J., Jr. (Org.). Check list of the freshwater fishes of South and Central America. Porto Alegre: EDIPUCRS, 2003. p. 174-181. 
LIMA, F.C.T.; BUCKUP, P.A.; MENEZES, N.A.; LUCENA, C.A.S.; LUCENA, Z.M.S.; TOLEDO-PIZA, M.; ZANATA, A. Família Characidae: Gêneros incertae sedis. In: BUCKUP, P.A.; MENEZES, N.A.; GHAZZI, M.S. (Ed.). Catálogo das espécies de peixes de água doce do Brasil. Rio de Janeiro: Museu Nacional, 2007. p. 44-62. (Série Livros, 23).

LIMA, F.C.T.; MALABARBA, L.R.; BUCKUP, P.A.; SILVA, J.F.P.; VARI, R.P.; HAROLD, A.; BENINE, R.C.; OYAKAWA, O.T.; PAVANELLI, C.S.; MENEZES, N.A.; LUCENA, C.A.S.; MALABARBA, M.C.S.L.; LUCENA, Z.M.S.; REIS, R.E.; LANGEANI, F.; CASATI, L.; BERTACO, V.A.; MOREIRA; C.; LUCINDA, P.H.F., Genera incertae sedis in Characidae. In: REIS, R.E.; KULLANDER, S.O.; FERRARIS, C.J., Jr. (Org.). Check list of the freshwater fishes of South and Central America. Porto Alegre: EDIPUCRS, 2003. p. 106-169.

LOYOLA, M.B.P. Variação geográfica de Geophagus brasiliensis (Quoy \& Gaimard, 1824) (Perciformes, Cichlidae). Maringá, 2005. 30 f., il. color. Monografia (Bacharelado em Ciências Biológicas) - Departamento de Biologia, Universidade Estadual de Maringá, Maringá, 2005.

LUCINDA, P.H.F. Family Poeciliidae (Livebearers). In: REIS, R.E.; KULLANDER, S.O.; FERRARIS, C.J., Jr. (Org.). Check list of the freshwater fishes of South and Central America. Porto Alegre: EDIPUCRS, 2003. p. 555-581.

LUCINDA, P.H.F. Systematics and biogeography of the genus Phalloceros Eigenmann, 1907 (Cyprinodontiformes: Poeciliidae: Poeciliinae), with the description of twenty-one new species. Neotropical Ichthyology, Porto Alegre, v. 6, no. 2, p. 113-158, 2008.

LUCINDA, P.H.F.; GARAVELLO, J.C. Two new species of Cnesterodon Garman, 1895 (Cyprinodontiformes: Poeciliidae) from the upper rio Paraná drainage. Comunicações do Museu de Ciências e Tecnologia da PUCRS, Série Zoológica, Porto Alegre, v. 13, n. 2, p. 119-138, 2001.

LUCINDA, P.H.F.; GHEDOTTI, M.J.; GRAÇA, W.J. A new Jenynsia species (Teleostei, Cyprinidontiformes, Anablepidae) from Southern Brazil and its phylogenetic position. Copeia, Lawrence, v. 4, p. 613-622, 2006.

LUNDBERG, J.G.; LITTMANN, M.W. Family Pimelodidae (Long-whiskered catfishes). In: REIS, R.E.; KULLANDER, S.O.; FERRARIS, C.J., Jr. (Org.). Check list of the freshwater fishes of South and Central America. Porto Alegre: EDIPUCRS, 2003. p. 432-446.

LUZ-AGOSTINHO, K.D.G.; BINI, L.M.; FUGI, R.; AGOSTINHO, A.A.; JÚLIO JÚNIOR., H.F. Food spectrum and trophic structure of the ichthyofauna of Corumbá Reservoir, Paraná River basin, Brazil. Neotropical Ichthyology, Porto Alegre, v. 4, no. 1, p. 61-68, 2006.

MAACK, R. Breves notícias sobre a geologia dos estados do Paraná e Santa Catarina. Brazilian Archives of Biology and Technology: an international journal, Curitiba, p.169-288, Dec. 2001. Ed. fac-sim. Artigo publicado no Arquivos de Biologia e Tecnologia, v.2, p.63-154, 1947. Edição especial Jubilee volume (1946-2001).

MAACK, R. Geografia física do Estado do Paraná. Apresentação Riad Salumuni. Introdução Aziz Nacib Ab'Sabber. 2.ed. Rio de Janeiro: J. Olympio; Curitiba: Secretaria da Cultura e do Esporte do Estado do Paraná, 1981. 442 p., il.

MALABARBA, L.R.; WEITZMAN, S.H. Description of a new genus with six new species from Southern Brazil, Uruguay and Argentina, with a discussion of a putative characid clade (Teleostei: Characiformes: Characidae). Comunicações do Museu de Ciências e Tecnologia da PUCRS, Série Zoológica, Porto Alegre, v. 16, n. 1, p. 67-151, 2003.

MARTINS, F. O.; LANGEANI, F. Rhinolekos, a new genus with three new species of Hypoptopomatinae (Siluriformes: Loricariidae) from upper rio Paraná. Neotropical Ichthyology, Porto Alegre, v. 9, no. 1, p. 65-78, 2011.

MENEZES, N.A.; GÉRY, J. Seven new Acestrorhynchin Characid species (Osteichthyes, Ostariophysi, Characiformes) with comments on the systematics of the group. Revue Suisse Zoologie, Genève, v. 90, no. 3, p. 563-592, 1983.

MENEZES, N.A.; RIBEIRO, A.C.; WEITZMAN, S.; TORRES, R.A. Biogeography of Glandulocaudinae (Teleostei: Characiformes: Characidae) revisited: phylogenetic patterns, historical geology and genetic connectivity. Zootaxa, Auckland, no. 1726, p. 33-48, 2008.

MENEZES, N.A.; WEITZMAN, S.H.; OYAKAWA, O.T.; LIMA, F.C.; CASTRO, R. M.C.; WEITZMAN, M.J. Peixes de água doce da Mata Atlântica: lista preliminar das espécies e comentários sobre conservação de peixes de água doce neotropicais = Freshwater fishes of Mata Atlântica: preliminary list of species and comments on conservation of Neotropical Freshwater fishes. São Paulo: Museu de Zoologia da Universidade de São Paulo, 2007. 407 p., il. col. 
MINEROPAR, Parque Nacional do Iguaçu. Disponível em: <http://www.mineropar.pr.gov.br/ modules/conteudo/conteudo.php?conteudo=12>. Acesso em: 10 dez. 2010.

MIRANDE, J.M. Weighted parsimony phylogeny of the family Characidae (Teleostei: Characiformes). Cladistics, Westport, v. 25, p. 574-613, 2009.

NELSON, J.S. Fishes of the world. $4^{\text {th }}$ ed. New York: J. Wiley, c2006. 601p., ill.

OYAKAWA, O.T. Family Erythrinidae (Trahiras). In: REIS, R.E.; KULLANDER, S.O.; FERRARIS, C.J., Jr. (Org.). Check list of the freshwater fishes of South and Central America. Porto Alegre: EDIPUCRS, 2003. p. 238-240.

PAIVA, M.P. Grandes represas do Brasil. Editerra Editorial, Brasília. 292p. 1982.

PAVANELLI, C.S. Família Parodontidae. In: BUCKUP, P.A.; MENEZES, N.A.; GHAZZI, M.S. (Ed.). Catálogo das espécies de peixes de água doce do Brasil. Rio de Janeiro: Museu Nacional, 2007. p. 18-19. (Série Livros, 23).

PAVANELLI, C.S. Family Parodontidae (Parodontids). In: REIS, R.E.; KULLANDER, S.O.; FERRARIS, C.J., Jr. (Org.). Check list of the freshwater fishes of South and Central America. Porto Alegre: EDIPUCRS, 2003. p. 46-50.

PAVANELLI, C.S. Revisão taxonômica da família Parodontidae (Ostariophysi:

Characiformes). São Carlos, 1999. 332 f., il. Tese (Doutorado em Ecologia e Recursos Naturais) Departamento de Ecologia e Biologia Evolutiva, Universidade Federal de São Carlos, São Carlos, 1999.

PAVANELLI, C.S.; BIFI, A.G. A new Tatia (Ostariophysi: Siluriformes: Auchenipteridae) from the rio Iguaçu Basin, Paraná State, Brazil. Neotropical Ichthyology, Porto Alegre, v. 7, no. 2, p. 199-204, 2009.

PAVANELLI, C.S.; OLIVEIRA, C.A.M. A redescription of Astyanax gymnodontus (Eigenmann, 1911), new combination, a polymorphic characid fish from the Rio Iguaçu basin, Brazil. Neotropical Ichthyology, Porto Alegre, v. 7, no. 4, p. 569-578, 2009.

PEREIRA, E.H.L. Resurrection of Pareiorhaphis Miranda Ribeiro, 1918 (Teleostei: Siluriformes: Loricariidae), and description of a new species from the Rio Iguaçu basin, Brazil. Neotropical Ichthyology, Porto Alegre, v. 3, no. 2, p. 271-276, 2005.

de PINNA, M.C.C.. Trichomycterus castroi, a new species of trichomicterid catfish from the Rio Iguaçu of Southeastern Brazil (Teleostei: Siluriformes). Ichthyological Exploration of Freshwaters, München, v. 3, no. 1, p. 89-95, 1992.

de PINNA, M.C.C.; WOSIACKI,W. Family Trichomycteridae (Pencil or parasitic catfishes). In: REIS, R.E; KULLANDER, S.O.; FERRARIS, C.J., Jr. (Org.). Check list of the freshwater fishes of South and Central America. Porto Alegre: EDIPUCRS, 2003. p. 270-290.

PRIOLI, S.M.A.P.; PRIOLI, A.J.; JÚLIO JÚNIOR., H.F.; PAVANELLI, C.S.; OLIVEIRA, A.V.; CARRER, H.; CARRARO, D.M.; PRIOLI, L.M. Identification of Astyanax altiparanae (Teleostei, Characidae) in the Iguaçu River, Brazil, based on mitochondrial DNA and RAPD markers. Genetics and Molecular Biology, Ribeirão Preto, v. 25, no. 4, p. 421-430, 2002.

REIS, R.E. Family Callichthyidae (Armored catfishes). In: REIS, R.E.; KULLANDER, S.O.; FERRARIS, C.J., Jr. (Org.). Check list of the freshwater fishes of South and Central America. Porto Alegre: EDIPUCRS, 2003. p. 291-309.

REIS, R.E. Revision of the neotropical catfish genus Hoplosternum (Ostariophysi: Siluriformes: Callichthyidae), with the description of two new genera and three new species. Ichthyological Exploration of Freshwaters. München, v. 7, no. 4, p. 299-326, 1997.

REIS, R.E.; KULLANDER, S.O.; FERRARIS, C.J., Jr. (Org.). Check list of the freshwater fishes of South and Central America. Porto Alegre: EDIPUCRS, 2003. 729 p.

REIS, R.E.; PEREIRA, E.H.L. Three new species of the loricariid catfish genus Loricariichthys (Teleostei: Siluriformes) from Southern South American. Copeia, Lawrence, no. 4, p. 1029-1047, 2000.

REIS, R.E.; PEREIRA, E.H.L; ARMBRUSTER, J.W. Delturinae, a new loricariid catfish subfamily (Teleostei, Siluriformes), with revisions of Delturus and Hemipsilichthys. Zoological Journal of the Linnean Society, London, v. 147, p. 277-299, 2006.

ŘÍČAN, O.; PIÁLEK, L.; ALMIRÓN, A. CASCIOTTA, J. Two new species of Australoheros (Teleostei: Cichlidae), with notes on diversity of the genus and biogeography of the Río de la Plata basin. Zootaxa, Auckland, no. 2982, p. 1-26, 2011. 
SAMPAIO, F.A.A. Estudos taxonômicos preliminares dos Characiformes (Teleostei, Ostariophysi) da bacia do rio Iguaçu, com comentários sobre o endemismo dessa fauna. São Carlos, 1988. 175 f., il. Dissertação (Mestrado em Ecologia e Recursos Naturais) - Departamento de Ecologia e Biologia Evolutiva, Universidade Federal de São Carlos, São Carlos, 1988.

SANTOS, G.M.; MERONA, B.; JURAS, A.A.; JÉGU, M. Peixes do baixo rio Tocantins: 20 anos depois da Usina Hidrelétrica Tucuruí. Brasília, DF: Eletronorte, 2004. 215 p. il. color.

SEVERI, W.; CORDEIRO, A.A.M. Catálogo de peixes da bacia do rio Iguaçu. Curitiba: IAP/ GTZ, 1994. 118 p., il.

SHIBATTA, O.A.; HOFFMANN, A.C. Variação geográfica em Corydoras paleatus (Jenyns) (Siluriformes, Callichthyidae) do sul do Brasil. Revista Brasileira de Zoologia, São Paulo, v. 22, n. 2, p. 366-371, 2005.

SIGLER, W.F.; SIGLER, J.W. Fishes of the Great Basin: a natural history. Reno: University of Nevada Press, 1987. 425p., ill.

SILFVERGRIP, A.M.C. A systematic revision of the Neotropical catfish genus Rhamdia (Teleostei, Pimelodidae). Stockholm: Department of Zoology, Stockholm University and Department of Vertebrate Zoology: Swedish Museum of Natural History, 1996. 156p., ill. +8 plates.

SUPERINTENDÊNCIA DE DESENVOLVIMENTO DE RECURSOS HÍDRICOS E SANEAMENTO AMBIENTAL. Qualidade das águas interiores do Estado do Paraná. $1987-$ 1995. Curitiba: SUDERHSA, 1997. 257p.

SUPERINTENDÊNCIA DOS RECURSOS HÍDRICOS E MEIO AMBIENTE DO ESTADO DO PARANÁ (SUREHMA). Bacia do rio Iguaçu: portaria Surehma $\mathrm{n}^{\circ} 020 / 92$ de 12 de maio de 1992. Disponível em: <http://www.recursoshidricos.pr.gov.br/arquivos/File/enquadramento-biguacu.pdf $>$. Acesso em: $10 \mathrm{dez} .2010$.

SUZUKI, H.I. Estratégias reprodutivas de peixes relacionadas ao sucesso na colonização em dois reservatórios do rio Iguaçu, Brasil. São Carlos, 1999. 97 p., il. Tese (Doutorado em Ecologia de Recursos Naturais) - Universidade Federal de São Carlos, São Carlos, 1999.

SUZUKI, H.I.; AGOSTINHO, A.A. Reprodução de peixes do reservatório de Segredo. In: AGOSTINHO, A.A.; GOMES, L.C. (Ed.). Reservatório de Segredo: bases ecológicas para o manejo. Maringá: Eduem, 1997. cap. 9, p. [163]-182.

SUZUKI, H.I.; PELICICE, F.M.; LUIZ, E. A.; LATINI, J. D.; AGOSTINHO, A.A. Reproductive strategies of the fish community of the Upper Paraná River Floodplain. In: AGOSTINHO, A.A.; RODRIGUES, L.; GOMES, L.C.; THOMAZ, S. M.; MIRANDA, L. E. (Ed.). Structure and functioning of the Paraná River and its floodplain LTER-Site 6 (PELD-Sítio 6). Maringá: Eduem, 2004. p. [125]-130.

SUZUKI, H.I.; VAZZOLER, A.E.A. de M.; MARQUES, E.E.; LIZAMA, M. de los A.P.; INADA, P. Reproductive ecology of the fish assemblages. In: THOMAZ, S.M.; AGOSTINHO, A.A.; HAHN, N.S. (Ed.). The Upper Paraná River and its floodplain: physical aspects, ecology and conservation. Leiden, The Netherlands: Backhuys Publishers, 2004. ch. 12, p. [271]-292. (Biology of inland waters).

UNIVERSIDADE ESTADUAL DE MARINGÁ. Nupélia/Copel. Reservatório de Salto Caxias: bases ecológicas para o manejo - Relatório final 2002. Elaborado por A.A. AGOSTINHO, C.S. PAVANELLI, H.I. SUZUKI, J.D. LATINI, L.C. GOMES, N.S. HAHN, R. FUGI, W.M. DOMINGUES. Maringá, 2002. 272 p., il. Apoio Copel.

UNIVERSIDADE ESTADUAL DO OESTE DO PARANÁ. Gerpel; FUNDAÇÃO UNIVERSITÁRIA DE TOLEDO. Análise biológica de peixes: bacias hidrográficas do Atlântico Sul e dos rios Tibagi, Ivaí, Piquiri e Iguaçu. Toledo, PR, 2008a. 415 p., il. color. ([Relatório técnico anual]-Apoio Copel).

UNIVERSIDADE ESTADUAL DO OESTE DO PARANÁ. Gerpel; FUNDAÇÃO UNIVERSITÁRIA DE TOLEDO. Estudos ictiológicos e monitoramento da qualidade das águas dos reservatórios de Salto Santiago e Salto Osório - rio Iguaçu/PR - Relatório - julho de 2003 a junho de 2006. Toledo, PR, 2006. 54 p., il. color. (Relatório-Apoio Tractebel Energia).

UNIVERSIDADE ESTADUAL DO OESTE DO PARANÁ. Gerpel; FUNDAÇÃO UNIVERSITÁRIA DE TOLEDO. Estudos ictiológicos e monitoramento da qualidade das águas dos reservatórios de Salto Santiago e Salto Osório - rio Iguaçu/PR: Salto Santiago Relatório anual - etapa iv, julho de 2006 a janeiro de 2008. Toledo, PR, 2008b. 205 p., il. color. (Relatório anual-Apoio Tractebel Energia). 
UNIVERSIDADE ESTADUAL DO OESTE DO PARANÁ. Gerpel; FUNDAÇÃO UNIVERSITÁRIA DE TOLEDO. Estudos ictiológicos e monitoramento da qualidade das águas dos reservatórios de Salto Santiago e Salto Osório - rio Iguaçu/PR: Salto Osório Relatório anual - etapa v, março de 2008 a janeiro de 2009. Toledo, PR, 2009a. 215 p., il. color. (Relatório anual-Apoio Tractebel Energia).

UNIVERSIDADE ESTADUAL DO OESTE DO PARANÁ. Gerpel; FUNDAÇÃO UNIVERSITÁRIA DE TOLEDO. Estudos ictiológicos e monitoramento da qualidade das águas dos reservatórios de Salto Santiago e Salto Osório - rio Iguaçu/PR: Salto Santiago Relatório anual - etapa v, março de 2008 a janeiro de 2009. Toledo, PR, 2009b. 221 p., il. color. (Relatório anual-Apoio Tractebel Energia).

UNIVERSIDADE ESTADUAL DO OESTE DO PARANÁ. Gerpel; FUNDAÇÃO UNIVERSITÁRIA DE TOLEDO. Estudos ictiológicos e monitoramento da qualidade das águas dos reservatórios de Salto Santiago e Salto Osório - rio Iguaçu/PR: Salto Santiago Relatório anual - etapa vi, março de 2009 a janeiro de 2010. Toledo, PR, 2010. 212 p., il. color. (Relatório anual-Apoio Tractebel Energia).

VARI, R.P. Family Curimatidae (Toothless characiformes). In: REIS, R.E.; KULLANDER, S.O.; FERRARIS, C.J., Jr. (Org.). Check list of the freshwater fishes of South and Central America. Porto Alegre: EDIPUCRS, 2003. p. 51-64.

VARI, R.P. Systematics of the Neotropical characiform genus Cyphocharax Fowler (Pisces: Ostariophysi). Washington, D.C.: Smithsonian Institution, 1992. iv, 137 p., ill. (Smithsonian contributions to Zoology; 529).

VARI, R.P. Systematics of the Neotropical characiform genus Steindachnerina Fowler (Pisces: Ostariophysi). Washington, D.C.: Smithsonian Institution, 1991. iv, 118 p., ill. (Smithsonian contributions to Zoology; 507).

VAZZOLER, A.E.A. de M.; SUZUKI, H.I.; MARQUES, E.E.; LIZAMA, M.L.P. Primeira maturação gonadal, períodos e áreas de reprodução. In: VAZZOLER, A.E.A. de M.; AGOSTINHO, A.A.; HAHN, N.S. (Ed.). A planície de inundação do alto rio Paraná: aspectos físicos, biológicos e socioeconômicos. Maringá: Eduem: Nupélia, 1997. cap. ii, p. [249]-265.

VITULE, J.R.S.; ABILHOA, V. A composição da ictiofauna na bacia hidrográfica do rio Piraquara, alto rio Iguaçu, Região Metropolitana de Curitiba, Paraná, Brasil. Estudos de Biologia, v. 25, n. 52 , p. $43-49,2003$.

WEBER, C. Subfamily Hypostominae (Armored catfishes). In: REIS, R.E.; KULLANDER, S.O.; FERRARIS, C.J., Jr. (Org.). Check list of the freshwater fishes of South and Central America. Porto Alegre: EDIPUCRS, 2003. p. 351-372.

WOSIACKI, W.B. Sistemática de Trichomycteridae (Ostariophysi-Siluriformes) na bacia do rio Iguaçu a montante das cataratas, com a descrição de oito espécies novas. Curitiba, 1997. 128 f., il. Dissertação (Mestrado em Zoologia) Departamento de Biologia, Universidade Federal do Paraná, Curitiba, 1997.

WOSIACKI, W.B.; GARAVELLO, J.C. Five new species of Trichomycterus from the rio Iguaçu (rio Paraná Basin), southern Brazil (Siluriformes: Trichomycteridae). Ichthyological Exploration of Freshwaters, München, v. 15, no. 1, p. 1-16, 2004.

WOSIACKI, W.B.; de PINNA, M.C.C. Família Trichomycteridae: Trichomycterinae. In: BUCKUP, P.A.; MENEZES, N.A.; GHAZZI, M.S. (Ed.). Catálogo das espécies de peixes de água doce do Brasil. Rio de Janeiro: Museu Nacional, 2007. p. 68-72. (Série Livros, 23).

WOSIACKI, W.B.; de PINNA, M.C.C. A new species of the Neotropical catfish genus Trichomycterus (Siluriformes: Trichomycteridae) representing a new body shape for the family. Copeia, Lawrence, no. 2, p. 273-278, 2008a.

WOSIACKI, W.B.; de PINNA, M.C.C. Trichomycterus igobi, a new catfish species from the rio Iguaçu drainage: the largest head in Trichomycteridae (Siluriformes: Trichomycteridae). Neotropical Ichthyology, Porto Alegre, v. 6, no. 1, p. 17-23, 2008b.

ZAWADZKI, C.H.; RENESTO, E.; BINI, L.M. Genetic and morphometric analysis of three species of the genus Hypostomus Lacépède, 1803 (Osteichthyes: Loricariidae) from the Rio Iguaçu basin (Brazil). Revue Suisse de Zoologie, Genève, v. 106, no. 1, p. 91-105, 1999. 


\section{Anexos}

\section{ANEXO 1. Lotes dos exemplares fotografados cadastrados.}

Cypriniformes. Cyprinidae. Ctenopharyndon idella: NUP 11897; Cyprinus carpio: NUP 12502; Hypophthalmichthys molitrix: NUP 11896; Hypophthalmichthys nobilis: NUP 2056. CharaCiformes. Parodontidae. Apareiodon vittatus: NUP 11854. Curimatidae. Cyphocharax cf. santacatarinae: NUP 11864; Steindachnerina brevipinna: NUP 11866. Prochilodontidae. Prochilodus lineatus: NUP 12040. Anostomidae. Leporinus aff. elongatus: NUP 1182; Leporinus friderici: NUP 11872; Leporinus macrocephalus: NUP 1417; Leporinus obtusidens: NUP 12192; Leporinus octofasciatus: NUP 11867. Crenuchidae. Characidium sp. 1: NUP 11853; Characidium sp. 2: MZUSP 85938. Serrasalmidae. Piaractus mesopotamicus: NUP 4375. Characidae. Astyanax bifasciatus: NUP 12092; Astyanax dissimilis: NUP 12093; Astyanax gymnogenys: NUP 1576; Astyanax jordanensis: MZUSP 99137; Astyanax longirhinus: NUP 11858; Astyanax serratus: NUP 11859; Astyanax sp. 1: NUP 3706; Astyanax sp. 2: NUP 3048; Gênero indeterminado sp.: NUP 12783; Hyphessobrycon reticulatus: NUP 11168; Oligosarcus longirostris: NUP 11856. Salmininae. Salminus brasiliensis: NUP 11894. Bryconinae. Brycon hilarii: NUP 8491. Stevardiinae. Bryconamericus ikaa: NUP 12091; Bryconamericus pyahu: NUP 12094; Bryconamericus sp.: NUP 11195; Cyanocharax aff. alburnus: NUP 11846; Mimagoniates microlepis: NUP 11865. Erythrinidae. Hoplias sp. 1: NUP 11855; Hoplias sp. 2: NUP 2074. SilURIFORMEs. Trichomycteridae. Trichomycterus castroi: NUP 3127; Trichomycterus crassicaudatus: NUP 10827; Trichomycterus davisi: NUP 4008; Trichomycterus igobi: NUP 9866; Trichomycterus mboycy: MPEG 6695; Trichomycterus papilliferus: NUP 10828; Trichomycterus plumbeus: NUP 10829; Trichomycterus stawiarski: NUP 10830; Trichomycterus taroba: NUP 1616. Callichthyidae. Callichthys callichthys: NUP 5490; Corydoras aff. paleatus: NUP 12635; Hoplosternum littorale: NUP 11201. Loricariidae. Neoplecostominae. Neoplecostomus sp.: NUP 4068; Pareiorhaphis cf. parmula: NUP 6105. Hypoptopomatinae. Hisonotus yasi: NUP 2545; Hisonotus sp.: NUP 2544. Loricariinae. Loricariichthys cf. melanocheilus: NUP 10791; Loricariichthys cf. rostratus: MHNCI 11044; Rineloricaria maacki: NUP 3059. Hypostominae. Ancistrus abilhoai: MZUSP 104116; Ancistrus agostinhoi: MZUSP 104118; Ancistrus mullerae: MZUSP 104121; Ancistrus sp. NUP 5781; Hypostomus 
albopunctatus: NUP 5432; Hypostomus derbyi: NUP 12631; Hypostomus myersi: NUP 12628. Heptapteridae. Heptapterus sp.: NUP 4676; "Pariolius" hollandi: NUP 5978; "Pariolius" sp.: NUP 6108; Rhamdia branneri: NUP 12633; Rhamdia voulezi: NUP 12634; Rhamdia sp.: NUP 6907. Ictaluridae. Ictalurus punctatus: NUP 11203. Auchenipteridae. Glanidium ribeiroi: NUP 11868; Tatia jaracatia: MZUSP 98251. Clariidae. Clarias gariepinus: NUP 11900. Pimelodidae. Pimelodus britskii: NUP 12632; Pimelodus ortmanni: NUP 11847; Pseudoplatystoma corruscans: NUP 11140; Pseudoplatystoma reticulatum: NUP 3247; Steindachneridion melanodermatum: NUP 11903. Gymnotiformes. Gymnotidae. Gymnotus inaequilabiatus: NUP 3213; Gymnotus sylvius: NUP 7369. Apteronotidae. Apteronotus ellisi: NUP 1812; Apteronotus sp.: NUP 3253. ATHERINIFOrmes. Odontesthes bonariensis: NUP 11857. CyPrinodontiformes: Poeciliidae. Cnesterodon omorgmatos: MCP 22742; Phalloceros harpagos: NUP 11869. Anablepidae. Jenynsia diphyes: NUP 606; Jenynsia eigenmanni: NUP 2862. Synbranchiformes. Synbranchidae. Synbranchus marmoratus: NUP 6487. Perciformes. Centrarchidae. Micropterus salmoides: NUP 11898. Cichlidae. Australoheros angiru: NUP 11190; Australoheros kaaygua: NUP 1839; Cichla kelberi: NUP 11862; Cichlasoma paranaense: NUP 2382; Crenicichla iguassuensis: NUP 11849; Crenicichla tesay: NUP 3731; Crenicichla yaha: NUP 11860; Geophagus brasiliensis: NUP 11851; Oreochromis niloticus: NUP 11895.

\section{ANEXO 2. Lotes dos exemplares medidos.}

CyPriniformes. Cyprinidae. Ctenopharyndon idella: NUP 2817, NUP 3633; Cyprinus carpio: NUP 597; Hypophthalmichthys molitrix: NUP 11287; Hypophthalmichthys nobilis: NUP 1817, NUP 2056, NUP 2363.

Characiformes. Crenuchidae. Characidium sp. 1: NUP 708, NUP 1634, NUP 2392, NUP 3792, NUP 4331, NUP 4332; Characidium sp. 2: MZUSP 85938. Characidae. Astyanax bifasciatus: NUP 1639, NUP 2038, NUP 2066, NUP 3696, NUP 4131; Astyanax dissimilis: NUP 2292, NUP 4118, NUP 4323, NUP 4337, NUP 4340; Astyanax gymnogenys: NUP 1576, NUP 2037; Astyanax longirhinus: NUP 595, NUP 1580, NUP 1644, NUP 2034, NUP 2953; Astyanax minor: NUP 614, NUP 734, NUP 2458, NUP 4119; Astyanax serratus: NUP 1578, NUP 2035; Astyanax sp. 1: NUP 3697, NUP 3706; Astyanax sp. 2: NUP 3048. Stevardiinae. Bryconamericus sp.: NUP 633, NUP 2399; Cyanocharax aff. alburnus: NUP 2461, NUP 4123; Gênero indeterminado sp.: NUP 12783; Mimagoniates microlepis: NUP 5068. Erythrinidae. Hoplias sp. 1: NUP 1646, NUP 1808, NUP 1823, NUP 4130, NUP 4343, NUP 11199, NUP 11855; Hoplias sp. 2: NUP 2074, 
NUP 12136, NUP 12392, NUP 12394. SILURIFOrmes. Trichomycteridae. Trichomycterus castroi: NUP 3127; Trichomycterus davisi: NUP 3121, NUP 4008; Trichomycterus stawiarski: NUP 10830. Callichthyidae. Callichthys callichthys: NUP 2380; Corydoras carlae: NUP 711, NUP 2436, NUP 4425; Corydoras ehrhardti: NUP 710, NUP 2437, NUP 4426; Corydoras cf. paleatus: NUP 605, NUP 1608, NUP 1741, NUP 2960, NUP 4133; Hoplosternum littorale: NUP 3630, NUP 11201. Loricariidae. Neoplecostominae. Neoplecostomus sp.: NUP 703, NUP 1670, NUP 2549, NUP 3734, NUP 3756; Pareiorhaphis sp.: NUP 6105. Hypoptopomatinae. Hisonotus yasi: NUP 2545, NUP 2546, NUP 2548; Hisonotus sp.: NUP 2544. Loricariinae. Loricariichthys cf. rostratus: MHNCI 11044. Hypostominae. Ancistrus sp.: NUP 5090, NUP 5095, NUP 5096, NUP 5097, NUP 5110; Hypostomus albopunctatus: NUP 593, NUP 684, NUP 1785, NUP 5432, NUP 5786, NUP 5931; Hypostomus commersoni: NUP 596, NUP 1592, NUP 1627, NUP 2541, NUP 4587, NUP 4588, NUP 5838, NUP 5890, NUP 5915; Hypostomus derbyi: NUP 151, NUP 585, NUP 1607, NUP 1828; Hypostomus myersi: NUP 150, NUP 557, NUP 680, NUP 1591, NUP 1675. Heptapteridae. Heptapterus sp.: NUP 4676; Imparfinis hollandi: NUP 1589, NUP 1800, NUP 2976, NUP 4788; Imparfinis sp.: NUP 1827, NUP 2390, NUP 3708, NUP 3710, NUP 3722, NUP 3758, NUP 4645; Rhamdia branneri: NUP 642, NUP 5302; Rhamdia voulezi: NUP 2669, NUP 3692, NUP 3721, NUP 3724, NUP 5271, NUP 5279; Rhamdia sp.: NUP 1628, NUP 5284, NUP 5285. Ictaluridae. Ictalurus punctatus: NUP 584. Auchenipteridae. Glanidium ribeiroi: NUP 601, NUP 1831, NUP 2396, NUP 4312, NUP 4315. Clariidae. Clarias gariepinus: NUP 3246. Pimelodidae. Pseudoplatystoma corruscans: NUP 413; Pseudoplatystoma reticulatum: NUP 3247, NUP 3500; Steindachneridion melanodermatum: NUP 694, NUP 2656. Perciformes. Centrarchidae. Micropterus salmoides: NUP 1586. Cichlidae. Australoheros kaaygua: NUP 700, NUP 2382, NUP 2430, NUP 2717, NUP 3250.

\section{ANEXO 3. Lotes dos exemplares fotografados frescos e não cadastrados.}

Characiformes: Characidae. Astyanax altiparanae; Astyanax gymnodontus; Astyanax minor. Siluriformes. Loricariinae. Hypostomus commersoni. Perciformes. Cichlidae. Tilapia rendalli.

\section{ANEXO 4. Exemplares testemunho da bacia do rio Iguaçu não relacionados nos anexos anteriores.}

CyPrINIfOrmes. Cyprinidae. Ctenopharyndon idella: NUP 11141; Cyprinus 
carpio: NUP 3064; Hypophtalmichthys molitrix: NUP 2383. CHARACIFORMES: Curimatidae: Steindachnerina brevipinna: NUP 11487. Prochilodontidae. Prochilodus lineatus: NUP 3251. Anostomidae. Leporinus aff. elongatus: NUP 12784; Leporinus macrocephalus: NUP 12786; Leporinus obtusidens: NUP 12788; Leporinus octofasciatus: NUP 12787. Serrasalmidae. Piaractus mesopotamicus: NUP 12785. Salmininae. Salminus brasiliensis: NUP 6222. Bryconinae. Brycon hilarii: NUP 3245. Siluriformes. Clariidae. Clarias gariepinus: NUP 3246. Pseudoplatystoma corruscans: NUP 11142. Gymnotiformes. Gymnotidae. Gymnotus inaequilabiatus: NUP 3787; Gymnotus sylvius: NUP 3043. Odontesthes bonariensis: NUP 11857. CyPrinodontiformes: Poeciliidae. Phalloceros harpagos: NUP 8715. SYNBRANCHIFORMES: Synbranchidae: Synbranchus marmoratus: NUP 1804.

Perciformes. Cichlidae. Cichla kelberi: NUP 11862; Oreochromis niloticus: NUP 3065; Tilapia rendalli NUP 11178. 
\begin{tabular}{|llllllll}
\hline$A$ & U & $T$ & 0 & $R$ & $E$ & $S$ \\
\hline
\end{tabular} 


\section{Gilmar Baumgartner}

Possui graduação em Ciências Biológicas pela Univ. Est. de Maringá (1990), mestrado em Ecologia de Ambientes Aquáticos Continentais pela Univ. Est. de Maringá (1994) e doutorado em Ecologia de Ambientes Aquáticos Continentais pela Univ. Est. de Maringá (2001). Atualmente, é professor associado da Univ. Est. do Oeste do Paraná. Tem experiência na área de recursos pesqueiros e engenharia de pesca, com ênfase em avaliação de estoques pesqueiros de águas interiores, atuando principalmente nos seguintes temas: ovos e larvas de peixes, ictiofauna, estudos de impacto ambiental, relatório de impacto ambiental, monitoramento limnológico e ictiológico de reservatórios (22 reservatórios no Estado do Paraná). Coordena o Grupo de Pesquisas em Recursos Pesqueiros e Limnologia.

\section{- Carla Simone Pavanelli}

Possui graduação em Ciências Biológicas (1987) e especialização (1990) pela Univ. Est. de Maringá, mestrado pela Univ. Federal do Rio de Janeiro (1994), doutorado pela Univ. Federal de São Carlos (1999) e pós-doutorado na Smithsonian Institution (2006). Há mais de 20 anos é bióloga da Univ. Est. de Maringá e curadora da Coleção Ictiológica do Nupélia. Tem experiência na área de zoologia, com ênfase em taxonomia e sistemática, atuando principalmente nos seguintes temas: ictiologia, sistemática, bacia do Prata, levantamento, ecologia e conservação de peixes de água doce. Tem orientado alunos da graduação e pós-graduação lato e stricto sensu e é revisora de vários periódicos nacionais e estrangeiros. Atualmente, também exerce a Coordenação Científica do Núcleo de Pesquisas em Limnologia, Ictiologia e Aquicultura (Nupélia).

\section{Dirceu Baumgartner}

Possui graduação em Engenharia Agrícola pela Univ. Est. do Oeste do Paraná (1996), mestrado em Engenharia Agrícola pela Univ. Est. do Oeste do Paraná (2003) e doutorado em Ecologia de Ambientes Aquáticos Continentais pela Univ. Est. de Maringá (2010). Atualmente é professor adjunto da Univ. Est. do Oeste do Paraná. Tem experiência nas áreas de engenharia agrícola, com ênfase em irrigação e drenagem; de ecologia de reservatórios, com ênfase em distribuição das abundâncias de espécies de peixes, zonação longitudinal e estabilidade ictiofaunística em reservatórios; e de ecologia de peixes de riachos.

\section{- Alessandro Gasparetto Bifi}

Possui graduação em Engenharia de Pesca pela Univ. Est. do Oeste do Paraná (2005). Mestrado em Ciências Ambientais pela Univ. Est. de Maringá (2008), onde atualmente é doutorando. Tem experiência na área de ecologia e zoologia, com ênfase em taxonomia, atuando, principalmente, nos seguintes temas: taxonomia de peixes de água doce, recursos pesqueiros, ecologia de riachos, rios e reservatórios.

\section{Tiago Debona}

Possui graduação em Engenharia de Pesca pela Univ. Est. do Oeste do Paraná (2005), onde atualmente é mestrando em Recursos Pesqueiros e Engenharia de Pesca. Tem experiência na área de recursos pesqueiros e engenharia de pesca, com ênfase em avaliação de estoques pesqueiros de águas interiores.

\section{Vitor André Frana}

Possui graduação em Engenharia de Pesca pela Univ. Est. do Oeste do Paraná (2003). Especialista em Desenvolvimento e Meio Ambiente pela Univ. Est. do Oeste do Paraná (2007). Mestrado em Recursos Pesqueiros e Engenharia de Pesca pela Univ. Est. do Oeste do Paraná (2011). Desde outubro de 2003 é técnico laboratorial pela Fundação Universitária de Toledo. Tem experiência na área de conservação de recursos pesqueiros, com ênfase em manejo e conservação de recursos pesqueiros de águas interiores. 


\author{
Copyright (c) 2012 para os autores \\ Gilmar Baumgartner \\ Carla Simone Pavanelli \\ Dirceu Baumgartner \\ Alessandro Gasparetto Bifi \\ Tiago Debona \\ Vitor André Frana \\ Produção Editorial \\ Sinergia - Mídia e Convergência \\ www.sinergiamc.com.br \\ 4430242907 \\ C. A. Venancio \\ Eliane Arruda \\ Maykon Patrick de Oliveira Martins \\ Leonardo Marques
}

\title{
Capa
}

Dura, 470 x 320 mm em Couchê Fosco 150 g/m²

Laminado Bopp Alto Brilho Total Frente

\section{Sobrecapa \\ 625 x 285 mm em Couchê Fosco 300 g/m²}

\section{Miolo}

224 páginas, 215 x 280 mm em Couchê Fosco

$115 \mathrm{~g} / \mathrm{m}^{2}$, Verniz IR Fosco Total Frente e Verso

\section{Tipografia}

Abadi MT - 1996 / Calibri - 2005 / Dax - 1997

Lao UI - 1997 / Segoe UI - 2004 / Times New

Roman - 1932 / Trajan Pro - 2001

Impressão

Gráfica Regente 